WSRC-TR-2002-00062, Rev. 0

SRT-RPP-2002-00022, Rev. 0

\title{
RPP-WTP Slurry Wear Evaluation: Slurry Abrasivity
}

January 31,2002

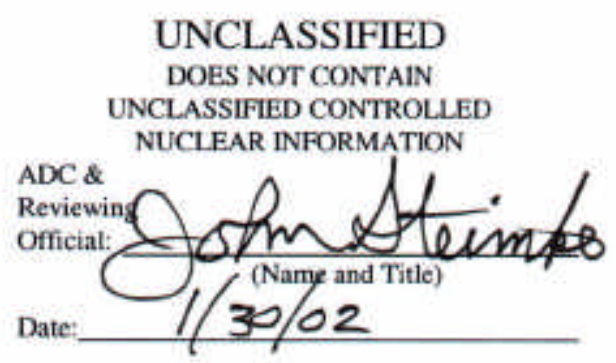

Westinghouse Savannah River Company

Savannah River Site 
WSRC-TR-2002-00062, Rev. 0

SRT-RPP-2002-00022, Rev. 0

KEYWORDS:

Hanford River Protection Project

Pretreatment

Filtration

Evaporator Erosion Corrosion

Stainless Steel

Hanford Waste

\title{
RPP-WTP Slurry Wear Evaluation: Slurry Abrasivity
}

\author{
SAVANNAH RIVER TECHNOLOGY CENTER
}

M.R. Duignan

January 31,2002

Westinghouse Savannah River Company

Savannah River Site

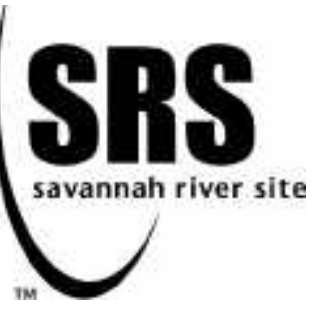


This document was prepared in conjunction with work accomplished under Contract No. DE-AC09-96SR18500 with the U. S. Department of Energy.

\section{DISCLAIMER}

This report was prepared as an account of work sponsored by an agency of the United States Government. Neither the United States Government nor any agency thereof, nor any of their employees, makes any warranty, express or implied, or assumes any legal liability or responsibility for the accuracy, completeness, or usefulness of any information, apparatus, product or process disclosed, or represents that its use would not infringe privately owned rights. Reference herein to any specific commercial product, process or service by trade name, trademark, manufacturer, or otherwise does not necessarily constitute or imply its endorsement, recommendation, or favoring by the United States Government or any agency thereof. The views and opinions of authors expressed herein do not necessarily state or reflect those of the United States Government or any agency thereof.

This report has been reproduced directly from the best available copy.

Available for sale to the public, in paper, from: U.S. Department of Commerce, National Technical Information Service, 5285 Port Royal Road, Springfield, VA 22161, phone: (800) 553-6847, fax: (703) 605-6900

email: orders@ ntis.fedworld.gov

online ordering: http://www.ntis.gov/support/index.html

Available electronically at http://www.osti.gov/bridge

Available for a processing fee to U.S. Department of Energy and its contractors, in paper, from: U.S. Department of Energy, Office of Scientific and Technical Information, P.O. Box 62, Oak Ridge, TN 37831-0062,

phone: (865)576-8401,

fax: (865)576-5728

email: $\underline{\text { reports@ adonis.osti.gov }}$ 
DOCUMENT: $\quad$ WSRC-TR-2002-00062, Rev. 0 (SRT-RPP-2002-00022)

TITLE: $\quad$ RPP-WTP Slurry Wear Evaluation: Slurry Abrasivity

\section{APPROVALS}

Mial R Dugnav- Date: $1 / 30 / 2002$ H.N. Henew Date: $2 / 14 / 2022$ H. N. Guerrero, Technical Reviewer (ETF Group/ED Section/EES Dept/SRTC)

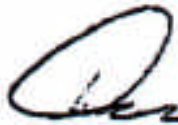

D. B. Burns, Level 4 Manager (ETF Group/ED Section/EES Dept./SRTC)
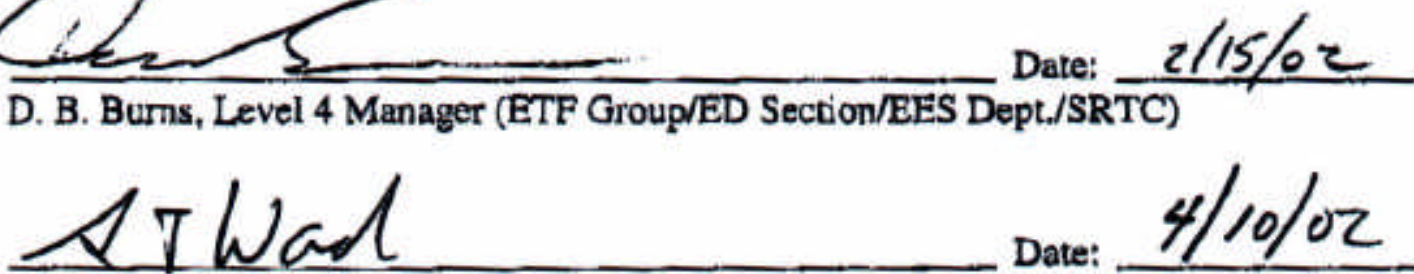

Date: $4 / 10 / 02$

S. T. Wach, Level 3 Manager (ED Section/EES Dept./SRTC)

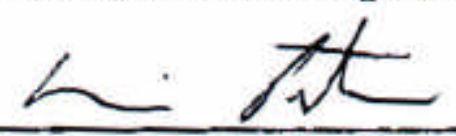

R. A. Peterson, RPP-WTP (Washington Group International)

Date: $4 / 10 / 02$ 
RPP-WTP Slurry Wear Evaluation: Literature Review

WSRC-TR-2002-00062, Rev. 0

SRT-RPP-2002-00022, Rev. 0

\section{Contents}

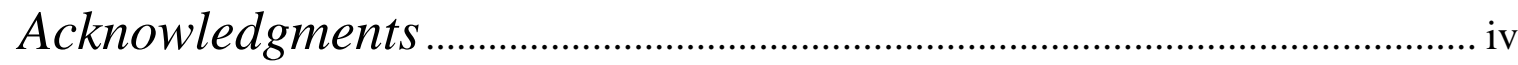

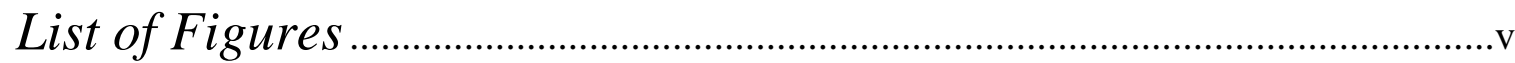

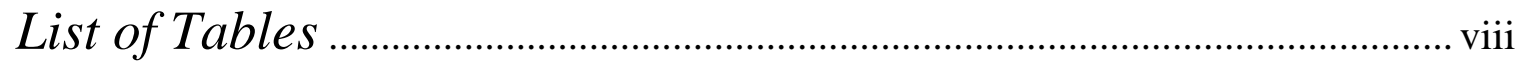

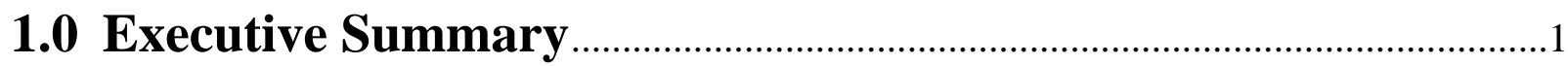

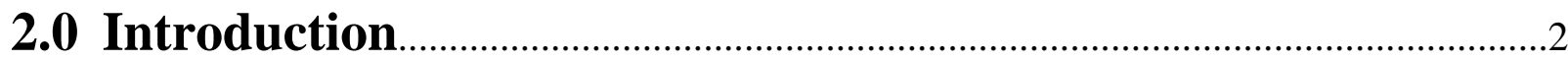

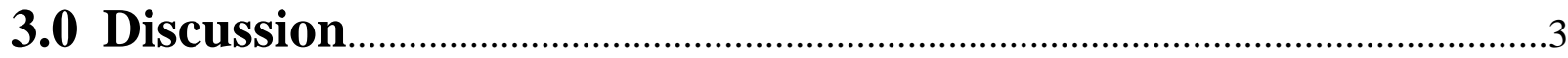

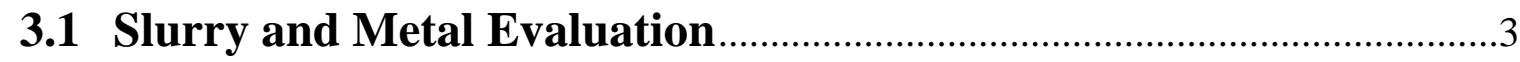

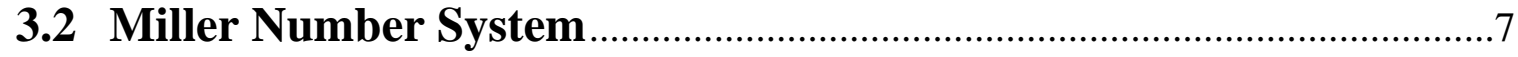

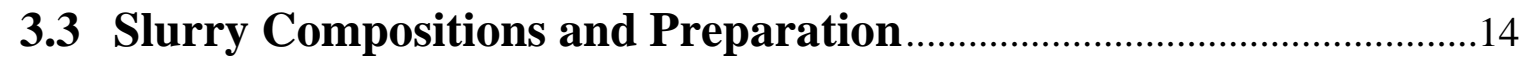

3.4 Metal Compositions and Preparation ………........................................

3.5 Quality Assurance ………………………..............................................49

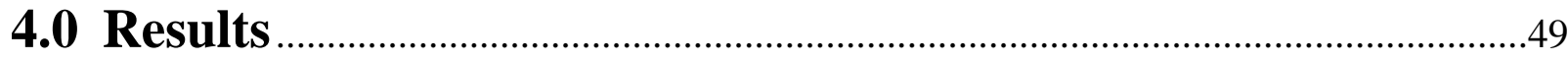

4.1 Overall Physical and Chemical Slurry Properties ..............................49

4.2 Slurry Abrasion Response Numbers ……………………………..........51

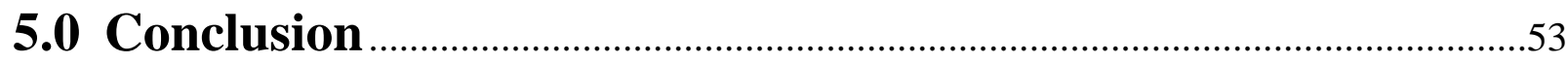

6.0 Recommendations

7.0 References

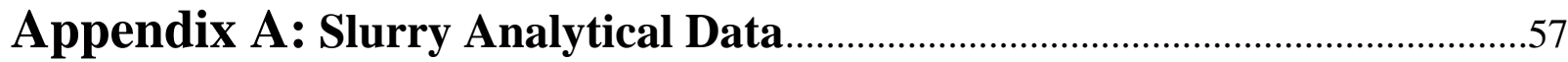

Appendix B: White Rock Engineering Services

Slurry Abrasivity Number Report 
RPP-WTP Slurry Wear Evaluation: Literature Review

WSRC-TR-2002-00062, Rev. 0

SRT-RPP-2002-00022, Rev. 0

\section{Acknowledgments}

Despite the fact that this task involved the abrasivity evaluation at a subcontractor, White Rock Engineering Services in Frisco, Texas, (WRES), there was a considerable amount of support work done at the Savannah River Site (SRS). To do each WRES test, simulated DOE Hanford Site wastes had to be supplied along with specimens of the metals that will be used to construct the in-cell piping of the River Protection Project - Waste Treatment and Immobilization Plant. Each slurry sent to WRES had to be designed, made, and chemically evaluated. The accompanying metal samples had to be procured and formed. Finally the items had to be prepared for shipping. Each step was important to the success of this task and dependent upon the expertise of many individuals. Unless stated otherwise, all of the following individuals are connected to the Savannah River Technology Center Division of the Westinghouse Savannah River Company (WSRC) at SRS.

For the metal samples: I want to thank Janet Brewer of the 749-A Machine Shop for obtaining the materials and pedigrees in a short time period. My thanks goes to Ken Imrich, of the Material Technology Section, for having made the samples to WRES's requirements and for suggesting a company to do the abrasivity testing. I would also like to thank Ken for his discussions on materials and on the methods for testing materials.

For the slurry simulants: first and foremost, I want to thank Chuck Coleman, of the Analytical Development Section, and Erich Hansen, of the Waste Processing Technology Section. Their assistance in making the slurries and analyzing the resulting products was extremely important to the success of this task. Each of the seven slurries used in this test required a significant effort to refine their design, to make them, to benchmark their chemical make-up, and then to ship them to WRES. The design phase continued until the last simulant was made and thanks are extended to Russ Eibling, Bond Calloway, and Charles Nash of the Waste Processing Technology Section, and to Mark Crowder of the Actinide Technology Section. The fabrication phase was the most labor intensive and it could not have been done without the help of Frances Williams of the Immobilization Technology Section, and all the fine technicians down at TNX. A significant amount of analytical testing was needed to properly characterize the simulants before being shipped, for this work I would like to thank John Young, Chuck Coleman, Beverly Burch, Leigh Brown, and all the other members of Analytical Development Section who had a hand. Finally, the simulant could not have left SRS to reach WRES in a safe manner, while meeting all the Department of Transportation Regulations, without the help of Susan Hatcher, Andy Foreman, Michael Armstrong, and Vernon Bush of the Engineering Development Section and all the folks in the Transportation Section of the Administration \& Infrastucture Division of WSRC.

I thank my technical reviewer, Hector Guerrero, of the Engineering Development Section, for a sharp eye. Finally, I would like to thank Gita Golcar of Pacific Northwest National Laboratory for helping me understand her HLW erosion simulant. A special thanks goes to Mike Johnson of $\mathrm{CH}_{2} \mathrm{M}$ Hill Hanford Group, Inc. for initially supporting this effort and to Reid Peterson of Washington Group International for his continued support. 
RPP-WTP Slurry Wear Evaluation: Literature Review

WSRC-TR-2002-00062, Rev. 0

SRT-RPP-2002-00022, Rev. 0

\section{List of Figures}

1. Miller Number System

2. Miller machine nomenclature

3. Metal specimens in place

4. Test stopped to measure wear rates

5. Slurry troughs

6. Neoprene lap surfaces

7a. Back stroke

7b. Forward stroke

8. Effect of particle hardness on abrasivity

9. Effect of particle size on abrasivity

10. Effect of particle concentration on abrasivity

11. Determining the SAR Number

12. Concentrations of several of the important elements in the AN-107 simulant

13. Rheology: Sr/TRU AN-107 simulant at $20 \mathrm{wt} \%$ insoluble solids at $25^{\circ} \mathrm{C}$ and $50^{\circ} \mathrm{C}$

14a. Solids in the LAW simulant: AN-107, entrained solids, and Sr/TRU precipitants: Particle size distribution by Volume

14b. Solids in the LAW simulant: AN-107, entrained solids, and Sr/TRU precipitants: Particle size distribution by Number

15. Concentrations of important elements in the HLW simulant

16. Rheology: AZ-101 simulant at $20 \mathrm{wt} \%$ insoluble solids at $25^{\circ} \mathrm{C}$

17. Rheology: AZ-101 Simulant versus 1989 real-waste samples 
RPP-WTP Slurry Wear Evaluation: Literature Review

WSRC-TR-2002-00062, Rev. 0

SRT-RPP-2002-00022, Rev. 0

18. Solids settling rates:AZ-101 real waste composite sample vs. the HLW simulant

19a. Solids in the HLW simulant: AZ-101, entrained solids: Particle size distribution by Volume

19b. Solids in the HLW simulant: AZ-101, entrained solids: Particle size distribution by Number

20. Concentrations of important elements in the HLWwSBS simulant

21. Rheology: HLW with SBS at $20 \mathrm{wt} \%$ insoluble solids at $25^{\circ} \mathrm{C}$ and $50^{\circ} \mathrm{C}$

22a. Solids in the HLW with SBS simulant at $20 \mathrm{wt} \%$ insoluble solids: Particle size distribution by Volume

22b. Solids in the HLW with SBS simulant at $20 \mathrm{wt} \%$ insoluble solids: Particle size distribution by Number

23. Concentrations of important elements in the leached HLW simulant

24. Rheology: leached HLW at $20 \mathrm{wt} \%$ insoluble solids at $25^{\circ} \mathrm{C}$ and $50^{\circ} \mathrm{C}$

25a. Solids in the HLW leached simulant: AZ-101, entrained solids: Particle size distribution by Volume

25b. Solids in the HLW leached simulant: AZ-101, entrained solids: Particle size distribution by Number

26. Concentrations of important elements in the washed HLW simulant

27. Rheology: washed HLW at $20 \mathrm{wt} \%$ insoluble solids at $25^{\circ} \mathrm{C}$ and $50^{\circ} \mathrm{C}$

28a. Solids in the HLW washed simulant: AZ-101, entrained solids: Particle size distribution by Volume

28b. Solids in the HLW washed simulant: AZ-101, entrained solids: Particle size distribution by Number

29. Concentrations of important elements in the washed > leached HLWwSBS simulant

30. Rheology: washed and leached HLW with SBS recycle at $20 \mathrm{wt} \%$ insoluble solids at $25^{\circ} \mathrm{C}$ 
RPP-WTP Slurry Wear Evaluation: Literature Review

WSRC-TR-2002-00062, Rev. 0

SRT-RPP-2002-00022, Rev. 0

and $50^{\circ} \mathrm{C}$

31a. Solids in the leached and washed HLW with SBS simulant at $20 \mathrm{wt} \%$ insoluble solids:

Particle size distribution by Volume

31b. Solids in the leached and washed HLW with SBS simulant at $20 \mathrm{wt} \%$ insoluble solids:

Particle size distribution by Number

32. Concentrations of important elements in the leached HLW simulant

33. Rheology: leached and washed HLW at $20 \mathrm{wt} \%$ insoluble solids at $25^{\circ} \mathrm{C}$ and $50^{\circ} \mathrm{C}$

34a. Solids in the HLW leached simulant: AZ-101, entrained solids: Particle size Distribution by Volume

34b. Solids in the HLW leached simulant: AZ-101, entrained solids: Particle size Distribution by Number

35. Typical metal specimen

36. Physical properties of seven test simulants

37. SAR Number for all 7 slurries with both 304L and 316L stainless steels Appendix B:

1. Test Results Summary 
RPP-WTP Slurry Wear Evaluation: Literature Review WSRC-TR-2002-00062, Rev. 0

SRT-RPP-2002-00022, Rev. 0

\section{List of Tables}

1. Slurry simulants selected to be tested for abrasivity

2a. Recipe of 5.5 $\mathrm{M} \mathrm{Na}^{+}$Supernatant for AN-107 waste simulant

2b. Recipe of entrained solids for AN-107 waste simulant

2c. Recipe of precipitation additives for AN-107 waste simulant

3. Recipe of Solids used for all HLW (AZ-101) waste simulants

4a. Recipe of HLW supernatant for AZ-101 waste simulant

4b. Recipe of Solids for AZ-101 waste simulant ( $20 \mathrm{wt} \%$ insoluble solids)

5a. Recipe of HLW supernatant for AZ-101 waste simulant

5b. Recipe of Solids for HLW waste simulant (3.3\% insoluble solids)

6a. Recipe of HLW leaching supernatant for AZ-101 waste simulant

6b. Recipe of Solids for AZ-101 waste simulant (18\% insoluble solids)

7a. Recipe of washed HLW supernatant for AZ-101 waste simulant

7b. Recipe of Solids for AZ-101 waste simulant (20 wt\% insoluble solids)

8a. Recipe of HLW supernatant for AZ-101 waste simulant

8b. Recipe of Solids for HLW waste simulant (3.3\% insoluble solids)

9a. Recipe of HLW leaching supernatant for AZ-101 waste simulant

9b. Recipe of Solids for AZ-101 waste simulant

10. Composition of the metal samples used for slurry abrasivity evaluations Appendix A:

A1. RPP-WTP Hanford Waste Simulant: HLW (AZ-101)

A2. RPP-WTP Hanford Waste Simulant: HLW (AZ-101) with SRS Recycle 
RPP-WTP Slurry Wear Evaluation: Literature Review WSRC-TR-2002-00062, Rev. 0

SRT-RPP-2002-00022, Rev. 0

A3. RPP-WTP Hanford Waste Simulant: LAW (AN-107) with Sr/TRU Precipitant

A4. RPP-WTP Hanford Waste Simulant: Leached HLW (AZ-101)

A5. RPP-WTP Hanford Waste Simulant: Leached HLW (AZ-101) with SRS Recycle

A6. RPP-WTP Hanford Waste Simulant: Washed HLW (AZ-101)

A7. RPP-WTP Hanford Waste Simulant: Leached then washed HLW (AZ-101)

Appendix B:

1. Test Results Summary

2. Standard AFS 50-70 Sand Test Results 


\subsection{Executive Summary}

Tests are planned to measure the wear rates in scaled flow loops that represent full-scale systems in the Pretreatment section of the Waste Treatment Plant to be built as part of the Department of Energy (DOE) River Protection Project. Those tests are to be done in the Experimental Thermal Fluids Laboratory of the Savannah River Technology Center at the DOE Savannah River Site.

This report deals with the task of evaluating wear in the cross-flow ultrafiltration system and specifically the need to define a representative slurry in order to obtain prototypic wear rates. The filtration system will treat many different wastes, but it is not practical to run a test for each one. This is especially true when considering that the planned period for testing is 2000 hours long and procurement of appropriate simulants is costly. Considering time and cost, one waste stream needs to be chosen to perform the wear test.

To make such a selection, seven different slurries were evaluated for their ability to abrade materials that will be used to construct the flow system, i.e., 304L and 316L stainless steels. These seven slurries are actually two waste streams that will eventually be a low (radio) activity (level) waste (LAW) and a high (radioactivity) level waste (HLW). The other five waste streams are the result of processing HLW before filtration, e.g., washing, leaching, or premixing with Submerged Bed Scrubber (SBS) condensate, which is recycled from the pretreatment evaporators, etc.

Seven waste stream simulants were made and then they were used in a standard abrasivity test (ASTM G75-2001) to produce a Slurry Abrasion Response (SAR) number with the two stainless steels. The slurry that would produce the highest SAR would be selected for the long-term wear test. The figure below (Fig. 37 in this report and reproduced here for convenience) shows that simulant number 5 (washed and leached HLW simulant with SBS recycle) produced the most wear for both stainless steel types.

This report details the development of each slurry, their chemical and physical properties, and the SAR number results for each one.

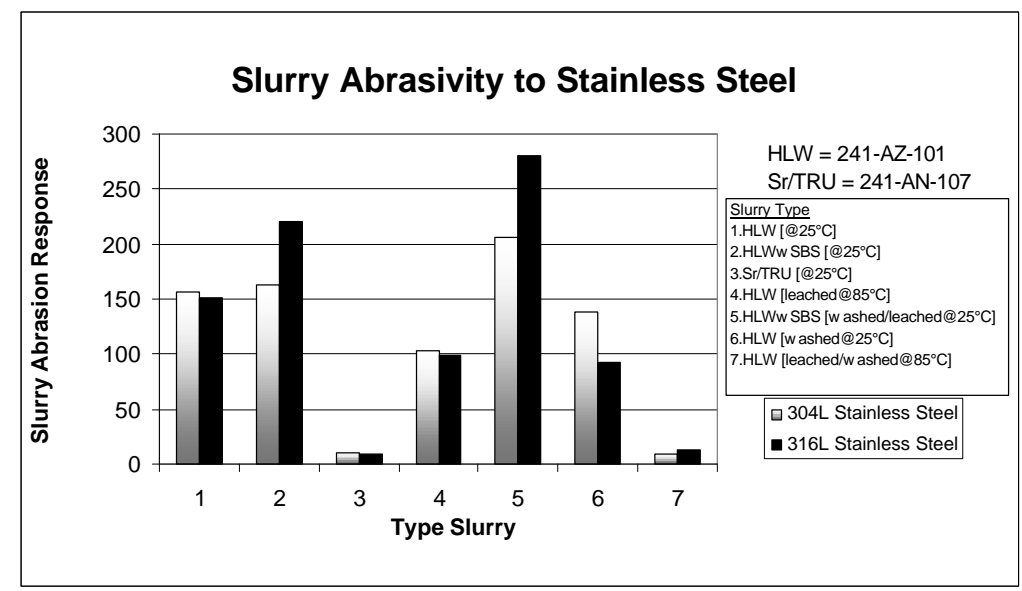




\subsection{Introduction}

Part of the River Protection Project (RPP) is to build a Waste Treatment \& Immobilization Plant (WTP) at the Hanford Site to stabilize the radioactive waste currently stored in large tanks at that site. The pretreatment system that prepares the waste for vitrification includes separation technologies like filtration and evaporation. These two systems will contain continuous flows of solids-liquid mixtures that will cause wear to the pipes and associated equipment. To have a system in good working order over the designed plant lifetime of 40 years, where maintenance must be minimized because of a radioactive environment, the rates of wear need to be quantified. Once the wear rates are known, design requirements and maintenance schedules can be developed to insure continuous safe plant operation.

To determine wear rates, experiments are planned to satisfy an RPP Test Specification (Johnson, et al., 2000) by developing scaled experiments to test both the cross-flow filtration system and the evaporation system. As a precursor to experiments, a literature review was done (Duignan and Lee, 2001) to examine prior work in this field, especially in the DOE complex. That review found the complexities of corrosion and erosion mechanisms make the estimation of pipe wear based on published studies difficult, if not impossible; generally a test is needed to accurately measure wear. Ideally such a test will be most accurate if it is done on the actual flow system, using the prototypic working fluid. However, most times, fully prototypic testing is not practical for many reasons that include: a system is only in the planning stage and not available, size, the cost of either the equipment or the working fluid, the actual working conditions, like a radioactive fluid, etc. For this present task the experiment will be scaled, because the separations systems are large, and the working fluid will be a simulant, because the actual slurries are radioactive. To properly scale the flow loop, a computational fluids dynamic analysis was done (Duignan, 2001a). To have a representative working slurry, a wear evaluation of several slurries was done and is the subject of this report.

As already stated, the more a test is non-prototypic, the more difficult it is to obtain representative results, therefore care must be taken. Because the design of the cross-flow filtration system was more advanced than that of the evaporator, and because of the larger number of slurries to be filtered, the wear in that system was chosen to be evaluated first. The filtration system will treat many different LAW (low activity wastes) and HLW (high level wastes) slurries. Further, HLW slurries will be subjected to different treatments like washing, leaching, or receiving additions like Submerge Bed Scrubber (SBS) recycle streams from the evaporators. A HLW from the Hanford tank 241- AZ-101 is thought to be the most abrasive of the first cycle of tanks to be processed by RPP-WTP because it had been previously selected by Battelle's Pacific Northwest National Laboratory (PNNL) due to its content of hard solids. A simulant of that waste was originally made by Golcar et al. (2000) and then it was specifically modified for erosion testing (Elmore, 2000). What is not well known is how the abrasivity of the slurry is affected by the different processes. 
To select a slurry that will be representative of one that will be the most abrasive to the filtration system, seven different slurry formulations were compared in a slurry abrasivity test called the SAR (Slurry Abrasivity Response) test. This test is a nationally accepted standard (ASTM G752001) to compare slurries as they are used to abrade a material surface of choice. For this work, both $304 \mathrm{~L}$ and $316 \mathrm{~L}$ stainless steels were used in the test since they are the materials of construction for the separation systems. This report shows the abrasivity results of the seven different slurries. The most abrasive slurry will be used to carry out a long-term wear test (2000 hours) in a scaled filtration system. Together with the results, details of the abrasivity tests are given below.

\subsection{Discussion}

\subsection{Slurry and Metal Evaluation}

One of the problems with conducting a long-term wear test for the cross-flow ultrafiltration system of RPP-WTP is the many slurries that will be processed. While the LAW streams will predominately filter $\mathrm{Sr} / \mathrm{TRU}$ precipitated slurries at moderate temperatures of $25^{\circ} \mathrm{C} \pm 5^{\circ} \mathrm{C}$ (Stiver, 2000), the HLW streams will treat different slurries under different conditions at both $25^{\circ} \mathrm{C} \pm 5^{\circ} \mathrm{C}$ and $85^{\circ} \mathrm{C} \pm 5^{\circ} \mathrm{C}$ (McTaggart, 2000; Bechtel, 2000 - Section C, Specification 12.2.2.2 (b) and 12.2.3.2 (b-g)). However, the current WTP flow sheet restricts all filtration to $25^{\circ} \mathrm{C} \pm 5^{\circ} \mathrm{C}$. A planned long-term wear test will be approximately 2000 hours in length, so to test all the slurries would take years to amass data, which is not practical. Moreover, many of the slurry simulants are very expensive to produce, and since each test may involve hundreds of liters of slurry, the expense to do many tests is also prohibitive. A better method would be to select one slurry, which will cause the most wear so that only a single test needs to be done for the cross-filtration system. The question is which slurry? The decision was to do a standard slurry wear test with all of the slurry combinations and system materials so that a comparison could be made and a slurry selected.

There are many types of slurry wear tests, e.g., pot tester, test with slurry jets, Coriolis tester, Miller tester. In general, results from any bench-top tester cannot be extrapolated to determine the wear rates in any flow loop system because of the many variables involved in slurry wear (Duignan and Lee, 2001). However, using the same standard wear test with different slurries, under the same conditions, will indicate which slurry is most abrasive to the particular material of which a flow loop will be constructed. The literature is filled with many versions of different types of wear testers, but only one has been made into an industrial accepted standard by the American Society of Testing \& Materials, i.e., Standard Test Method for Determination of Slurry Abrasivity (Miller Number) and Slurry Abrasion Response of Materials (SAR Number), ASTM G 75-2001, Ed. 07/2001. This standard was chosen to compare the slurries in order to select one for the long-term flow loop test and it will be described in the next section. 
There are many different types of radioactive wastes stored at the Hanford Site. Most of them will be processed by the RPP-WTP. Each tank of waste is a different mixture of complex chemicals. However, all the waste can generally be classified into two groups: Low (Radio-) Activity (Level) Wastes (LAW) and High (radioactivity) Level Wastes (HLW). In evaluating the slurries with respect to their abrasive response, it is important to choose those that would be the most aggressive. Candidate waste simulants considered are described below.

Many of the wastes are classified as LAW, but the primary interest is in those that will have the highest abrasion capabilities. The LAW slurries that contain "organic complexing agents and their decompositions products...will require..." a precipitation step to reduce the concentrations of Sr and Transuranic compounds (Eibling and Nash, 2000). These slurries are referred to as $\mathrm{Sr}$ TRU and because of the extra processing steps they will contain both entrained solids and precipitated solids. With the extra solids, the Sr/TRU LAW slurries are assumed to be more abrasive than straight LAW slurries. For the wear test, the Sr/TRU waste from Tank 241-AN107 was simulated since a recipe exists (Eibling and Nash, 2000). When the LAW slurry undergoes precipitation, its insoluble solids concentration will be close to $2 \mathrm{wt} \%$. It will then be concentrated to $20 \mathrm{wt} \%$ by a cross-flow filter. The simulant for abrasivity testing will therefore be concentrated to $20 \mathrm{wt} \%$.

- This abrasion test simulant is referred to as: Sr/TRU (or slurry No. 3)

The HLW slurries have a larger variation of processing in pretreatement, such as: washing, leaching, submerged bed scrubber (SBS) recycling, glass former blending, etc. All of these different HLW processed wastes will have insoluble solids in different forms. The combination of different slurries and processing steps that result in the most abrasive mixture is not obvious. A HLW considered abrasive by both the Savannah River Technology Center (SRTC) and Pacific Northwest National Laboratory (PNNL) is the waste from the Hanford site tank 241-AZ-101 (AZ-101) because of a high percentage of hard insoluble sludge solids. That waste has been previously characterized (Hodgson, 1995; Rapko and Wagner, 1997) and a sample of actual AZ101 waste and one of simulated AZ-101 waste were evaluated (McGrail, 1991) for abrasivity using an in-house Miller Number Machine. Unfortunately, the abrasivity data were not qualified and the test procedure, which was used, makes their use questionable. However, the results did show that the simulated waste gave the same wear results as the actual waste. The fact that AZ101 waste was an early choice for abrasion testing and that a simulant gave similar wear results makes it a good candidate for this test. Recently, the simulant for AZ-101 was refined (Golcar, et al., 2000) for cross-flow filtration testing and it was further altered (Elmore, 2000) to make it more representative as an abrasive waste. That is, a simulant is necessary for testing because the actual waste is radioactive and expensive to test. However, one of the radioactive insoluble solids is uranium oxide, which is considered hard and therefore abrasive. That compound was replaced with Tungsten oxide (because of its similar density) to maintain the high level of abrasivity. A Slurry Abrasion Response Number test was done (Elmore, 2000) with the new AZ101 simulant and the slurry was found abrasive to 316L stainless steel, but it was not tested with 304L. For the current slurry evaluation, AZ-101 was chosen once again for abrasivity testing to represent HLW. Since several HLW streams will be subjected to different pretreatment 
processes, that may affect abrasivity, a different AZ-101 simulant slurry was produced for each process. Those different processes are:

- HLW that is just concentrated to $20 \mathrm{wt} \%$ insoluble solids. This simulant is referred to as HLW (or slurry No. 1).

- HLW that is washed to dilute the high caustic supernatant and then concentrated to 20 wt $\%$ insoluble solids. This simulant is referred to as HLWwashed (or slurry No. 6).

- HLW that is washed to dilute the high caustic supernatant and then concentrated to $20 \mathrm{wt} \%$ insoluble solids. It is then leached in $3 \mathrm{M} \mathrm{NaOH}$ at $85^{\circ} \mathrm{C}$ for a minimum of 8 hours and then reconcentrated to $20 \mathrm{wt} \%$. This simulant is referred to as HLWleached (or slurry No. 4).

- HLW that is washed to dilute the high caustic supernatant and then concentrated to $20 \mathrm{wt} \%$ insoluble solids. It is then leached in $3 \mathrm{M} \mathrm{NaOH}$ at $85^{\circ} \mathrm{C}$ for a minimum of 8 hours and then reconcentrated to $20 \mathrm{wt} \%$. It is finally washed 2 times to dilute the high caustic supernatant; each wash is done at $85^{\circ} \mathrm{C}$ for a minimum of 8 hours and then reconcentrated to $20 \mathrm{wt} \%$ insoluble solids. This simulant is referred to as HLWleached/washed (or slurry No. 7).

- Two more effects on the HLW slurries will not be pretreatments but artifacts of the how the pretreatment process operates. That is, there will be a waste stream returning from the action of scrubbing the HLW evaporator offgas. This waste stream is referred to as the Submerged Bed Scrubber recycle, which will also include some of the glass formers and glass fines (called SBS). SBS was included in the HLW simulant before any processing occurs. These simulants are referred to as: HLWwSBS (or slurry No. 2) and HLWwSBS washed\&leached (or slurry No. 5), respectively.

The other important factor in abrasion testing of slurries is the material that will be abraded. That is, of what material will the pretreatment ultrafiltration system be made? At the time this wear-test task was developed two metals were indicated for use, i.e., 304L for in-cell pipe (RPPWRT documentation No. SP W375-M00001, Rev. A, 1/6/2000) and 316L for the cross-flow filter unit. Both of these metals are used in this test to determine the combination of slurry and material that will present the most abrasivity.

The entire test matrix of slurry and material combinations is listed in Table 1. The order of the slurries in the table was initially chosen to do the main three different slurries first i.e., HLW, HLW with SBS, then Sr/TRU, to be followed by different treatments of the HLW, i.e., leached and washed. The slurry and metal sample numbering reflects this order, which was used by the wear test subcontractor. However, for several reasons (e.g., unavailability of certain chemicals) the actual chronological order turned out different than planned. It was: No. 3 (Jan. 01), No. 1 (Mar. 01), No. 6 (Apr. 01), No. 4 (May 01), No. 7 (May 01), No. 2 (Sept. 01), and No. 5 (Nov. $01)$. 
Table 1. Slurry simulants selected to be tested for abrasivity

\begin{tabular}{ll} 
No. & \multicolumn{1}{c}{ Slurry } \\
1. & HLW \\
2. & HLWwSBS \\
3. & Sr/TRU \\
4. & HLWleached \\
5. & HLWwSBSwashed\&leached \\
6. & HLWwashed \\
7. & HLWleached\&washed
\end{tabular}

Metal Specimen* Temperature

$304 \mathrm{~L}-1 \mathrm{~A} / \mathrm{B} \& 316 \mathrm{~L}-1 \mathrm{~A} / \mathrm{B} \quad 25^{\circ} \mathrm{C} \pm 5^{\circ} \mathrm{C}$

$304 \mathrm{~L}-2 \mathrm{~A} / \mathrm{B} \& 316 \mathrm{~L}-2 \mathrm{~A} / \mathrm{B} \quad 25^{\circ} \mathrm{C} \pm 5^{\circ} \mathrm{C}$

$304 \mathrm{~L}-3 \mathrm{~A} / \mathrm{B} \& 316 \mathrm{~L}-3 \mathrm{~A} / \mathrm{B} \quad 25^{\circ} \mathrm{C} \pm 5^{\circ} \mathrm{C}$

$304 \mathrm{~L}-4 \mathrm{~A} / \mathrm{B} \& 316 \mathrm{~L}-4 \mathrm{~A} / \mathrm{B} \quad 85^{\circ} \mathrm{C} \pm 5^{\circ} \mathrm{C}$

$304 \mathrm{~L}-5 \mathrm{~A} / \mathrm{B} \& 316 \mathrm{~L}-5 \mathrm{~A} / \mathrm{B} \quad 25^{\circ} \mathrm{C} \pm 5^{\circ} \mathrm{C}^{* *}$

304L-6A/B \& 316L-6A/B $25^{\circ} \mathrm{C} \pm 5^{\circ} \mathrm{C}$

304L-7A/B \& 316L-7A/B $85^{\circ} \mathrm{C} \pm 5^{\circ} \mathrm{C}$

* The two metals used for testing were: 304L and 316L. For each metal, the nomenclature, i.e., $3 \times x L-n A / B$, indicates that two specimens of 3xxL, i.e., A and B, were used with each n slurry. That is, two tests were done using the same n slurry and two $304 \mathrm{~L}$ specimens, to obtain a better estimate of the wear rate. For example, 304L-1A, indicates that the A sample of 304L stainless steel metal was tested with slurry number 1 ( $n=1=$ HLW).

** Slurry number 5 was to be filtered initially by RPP-WTP (as well as the other leached slurries numbers 4 and 7) at the leaching temperature $85^{\circ} \mathrm{C}$, but by the time this slurry was ready to test (Nov. 2001) the cross-flow filtration system process changed such that all elevated temperature mixing would be isolated to the ultrafiltration feed preparation tanks. That is, RPP-WTP will cool the slurries to $25^{\circ} \mathrm{C} \pm 5^{\circ} \mathrm{C}$ before filtering begins, therefore the filter loop is not expected to experience the higher temperatures.

Testing each slurry and metal combination with the Miller Number System results in a Slurry Abrasion Response Number, which is explained in the next section; the larger the number the more abrasive a slurry is to a material. The combination with the largest SAR number will then be used in a pilot-scale flow-loop wear test. 


\subsection{Miller Number System}

The Miller Number test has been around since $1967^{\dagger}$, and it was originally developed to determine the abrasivity of a slurry in a closed-loop pump test (Miller and Miller, 1993). Since then it has evolved into a test to measure the relative abrasivity of many slurries and has been adopted by the American Society of Testing Materials as ASTM G75-2001: "Standard Test Method of Determination of Slurry Abrasivity (Miller Number) and Slurry Abrasion Response of Materials (SAR Number)." Specific definitions of those two numbers are given in the Standard and are quoted here:

"Miller Number - a measure of slurry abrasivity as related to the instantaneous rate of mass loss of a standard metal wear block at a specific time on the cumulative abrasion-corrosion time curve."

"SAR Number - a measure of the relative abrasion response of any material in any slurry, as related to the instantaneous rate of mass loss of a specimen at a specific time on the cumulative abrasion-corrosion time curve..."

For the Miller Number, the test is designed to use a standard metal specimen, a $27 \%$ chromiumiron wear block, which is composed of: C-2.5\%, Mn-1.0\%, Si-0.6\%, Ni-0.25\%, Cr-28\%, Mo$0.3 \%$, V-0.8\%, with iron making up the balance $(66.6 \%)$. This metal was chosen when the Miller Number System was first developed because it was commonly used in pipeline applications. The Miller Number $(\mathrm{MN})$ has been defined such that $\mathrm{MN}=1$ for a non-abrasive mixture of $50 \mathrm{wt} \%$ of sulfur (Mohs =1) and water and $\mathrm{MN}=1000$ for a very abrasive mixture of $50 \mathrm{wt} \%$ of 220-mesh Corundum (Mohs $=9$ ) and water. Through years of testing it has been found that a Miller Number of more than 50 indicates a slurry that is abrasive and care must be taken to monitor a piping system components, e.g., pumps, because wear is expected.

The SAR Number test is more general than the Miller Number test in that it applies to all slurries and all materials. The infinite number of slurry-metal combinations leads to more uncertainty in the SAR Number, but from years of testing different combinations, a rule of thumb has been developed that a SAR Numbers greater than 80 indicates a slurry that is abrasive to the wear specimen used and care must be taken to monitor a piping system because wear is expected. While the value of a SAR number may be difficult to apply in an absolute sense, it can be very useful in comparing the relative abrasivity of different slurry mixtures to a certain material or materials.

\footnotetext{
† In 1967, erosion to pump components was being evaluated in a closed-loop pump test. This test was for the Savage River Pipeline that tranports iron ore 90 kilometers from a mine to a processing plant on the coast of Tasmania, Australia. The slurry contained Magnetite particles with an approximate mean size of 44 microns. The Miller Number System was used to measure the reduction in abrasivity of the slurry with time to know when to replenish the slurry with fresh particles in the closed-loop test in order to maintain a constant level of abrasivity.
} 
WSRC-TR-2002-00062, Rev. 0

SRT-RPP-2002-00022, Rev. 0

\subsubsection{The Miller Number System Equipment}

Figure 1 shows a picture of the Miller Number System test apparatus with three of its four reciprocating arms in place. Figure 2 shows a profile of one reciprocating arm, along with the nomenclature of the different parts. The test apparatus operation is simply the movement of a sample material back and forth on a lap material while being submerged in the test slurry. A specimen is pressed on the lap surface with a $22.24 \mathrm{~N}\left(5 \mathrm{lb}_{\mathrm{f}}\right)$ weight and it is moved along the surface at a constant speed of 48 stokes per minute. Each stroke is $200-\mathrm{mm}$ long and at the end of each forward stroke a cam picks up the specimen from the lap surface a distance of $0.8 \mathrm{~mm}$ to allow the slurry to fill the gap. Operational parameters like reciprocation speed, lap material, time duration of a test, etc., have been refined when the test procedure was established for the ASTM standard. Details of that work is beyond the scope of this report and can be found in the standard and in Miller and Miller, 1993. Only certain aspect of the operational parameters are discussed here to better understand the results obtained from this test.

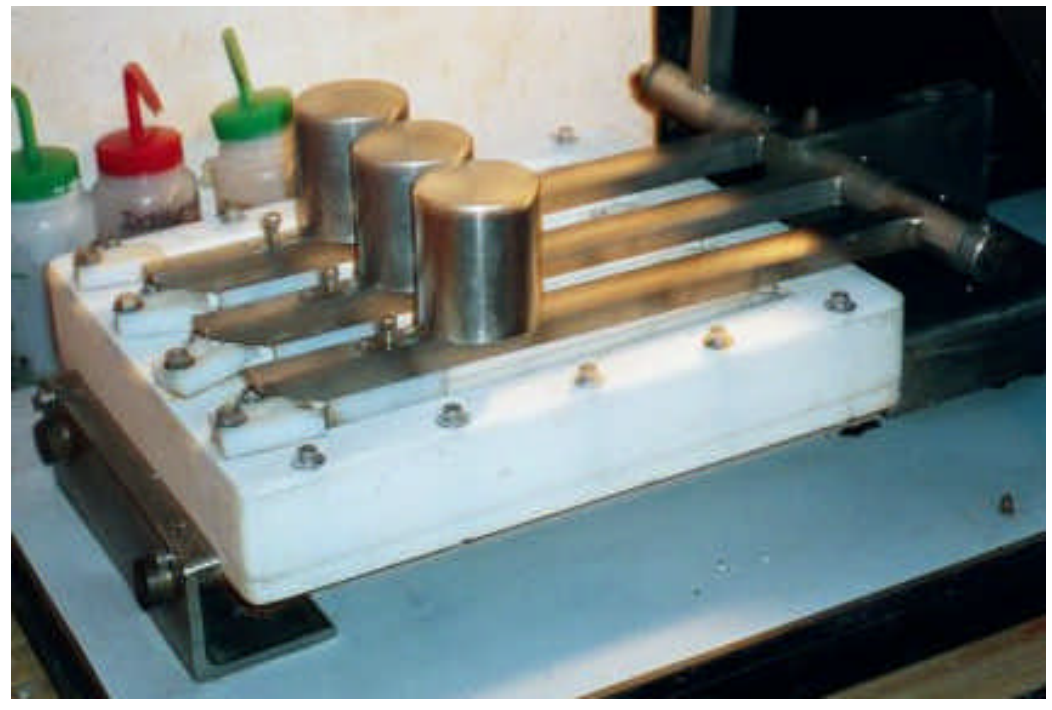

Figure 1. Miller Number System

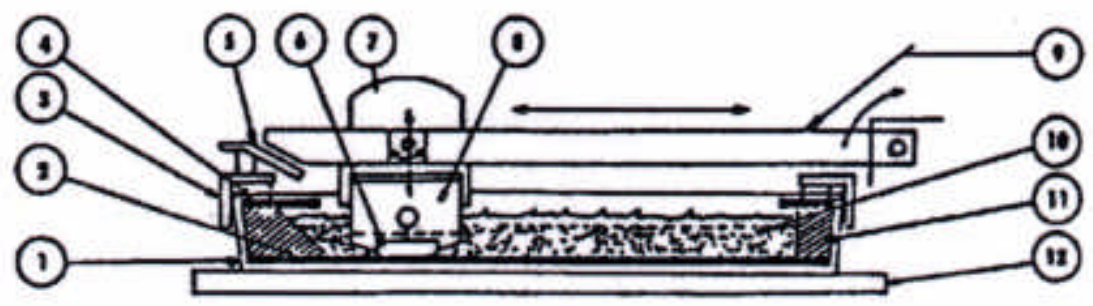

Figure 2. Miller machine nomenclature (Figure 2 from ASTM G 75-2001, Edition: 7/01):

1. Molded Plastic Tray 4. Splash Guard

2. Neoprene Lap

5. Block Lifting Cam

3. Tray Clamp

6. Wear Block
7. Dead Weight $(22.24 \mathrm{~N})$

8. Plastic Wear-Block Holder

9. Pivoted Reciprocating Arm
10. Slurry

11. Plastic Filler "V" Channel

12. Tray Plate 
As shown in Fig. 3, the test apparatus can hold up to four specimens to be tested at the same time. However, two of the specimens and slurries are the same to obtain repeat results, leading to a better estimate of the wear rate. Each test is six-hour long, during which wear is measured every two hours by weighing the specimens. Figure 4 shows a test stopped to remove the specimens during one of the two-hour intervals to measure how much mass has been removed. Before the mass measurement is made, each specimen it returned to its original clean state by washing it with a detergent and water, then drying it in an oven at $175^{\circ} \mathrm{C}$ for 15 minutes. After the measurement, the specimen is returned to the test apparatus and the test continues until three two-hour intervals are complete.

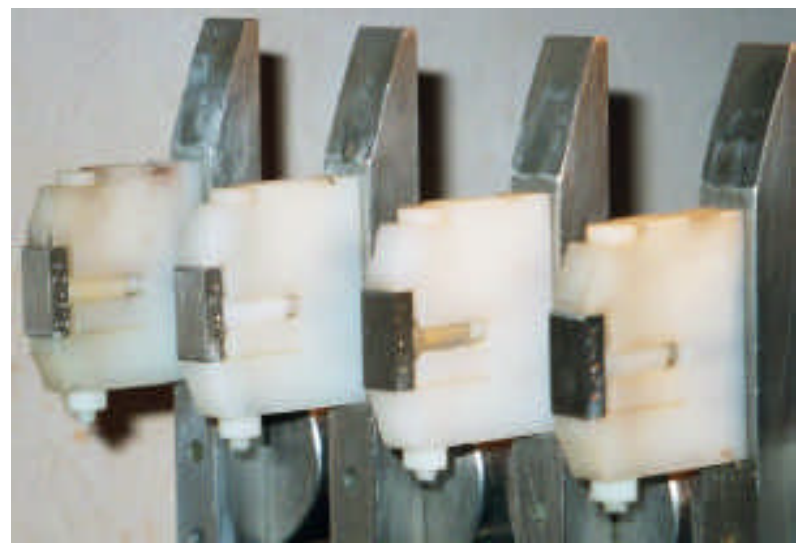

Figure 3. Metal specimens in place

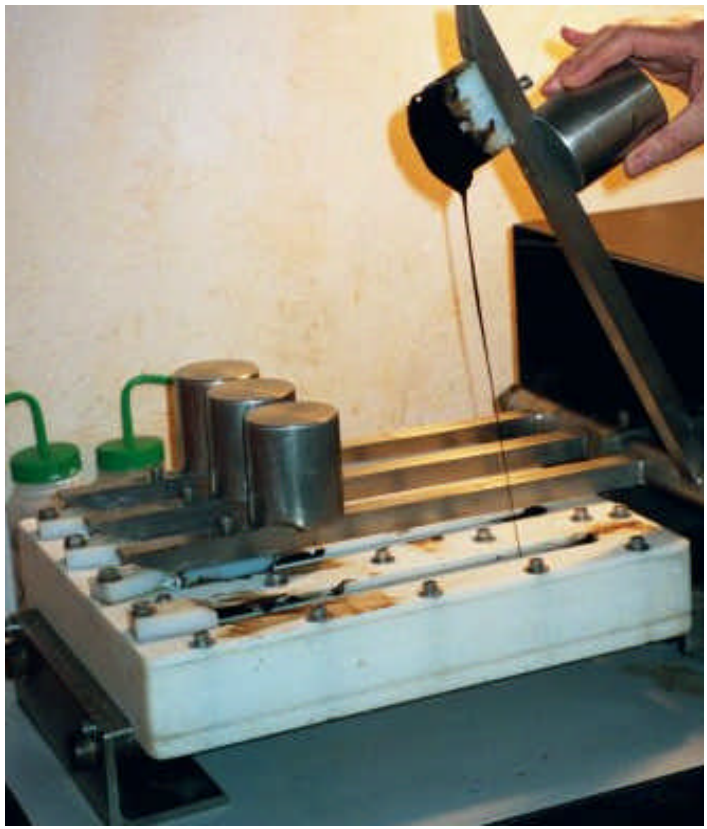

Figure 4. Test stopped to measure wear rates

Other aspects of the test apparatus are the slurry troughs, Fig. 5, and the Neoprene lap material, Fig. 6. Each trough is $50 \mathrm{~mm}$ ( 2 inches) wide and deep, $381 \mathrm{~mm}$ (15 inches) long, and filled with about $230 \mathrm{ml}$ of slurry during operation. To help direct the solids towards the specimen and lap surface the sides of the troughs are beveled, which cause a trough to become narrower with depth. Figure 5 shows the empty troughs with the lap surfaces in place. Figure 6 shows the Neoprene lap surfaces removed from the test apparatus. Past experience (Miller and Miller, 1993) has shown that results are dependent upon the hardness of the lap material; therefore a special molded neoprene rubber is used, specified as MIL-R-6855C, Class 2, Grade 80. The lap strips are $3.18 \mathrm{~mm}$ (1/8 inch) thick, $57.2 \mathrm{~mm}$ (2 1/4 inches ) wide, and long enough to fit the test apparatus. 
WSRC-TR-2002-00062, Rev. 0

SRT-RPP-2002-00022, Rev. 0

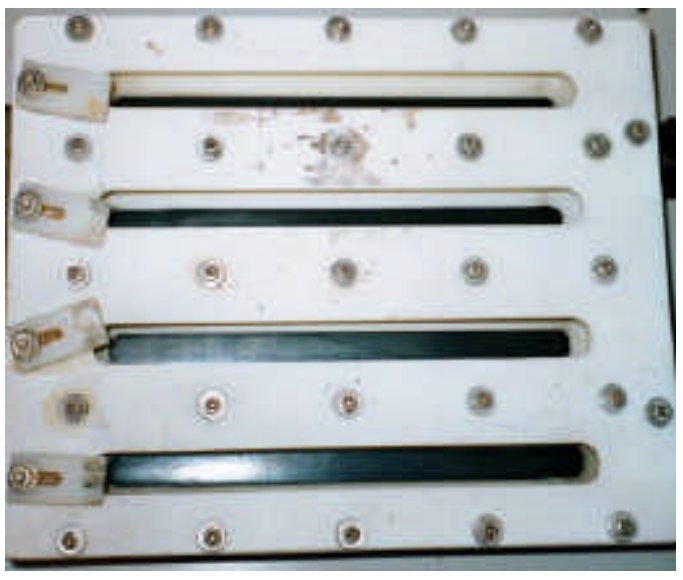

Figure 5. Slurry troughs

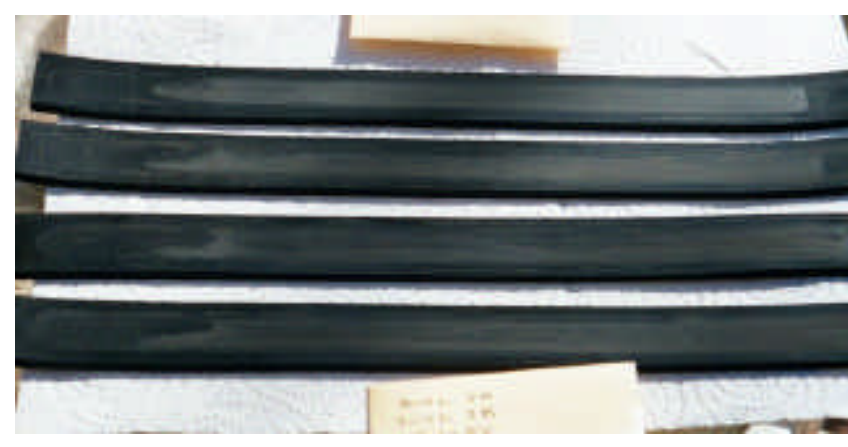

Figure 6. Neoprene lap surfaces

Figure 7 show the Miller Number Machine in operation (a) at the end of a backstroke and (b) as the arms approaching the cam at the end of the forward stroke, which will lift it $0.8 \mathrm{~mm}$ off the bottom of the trough to allow slurry to fill the gap between the specimen and the lap surface.

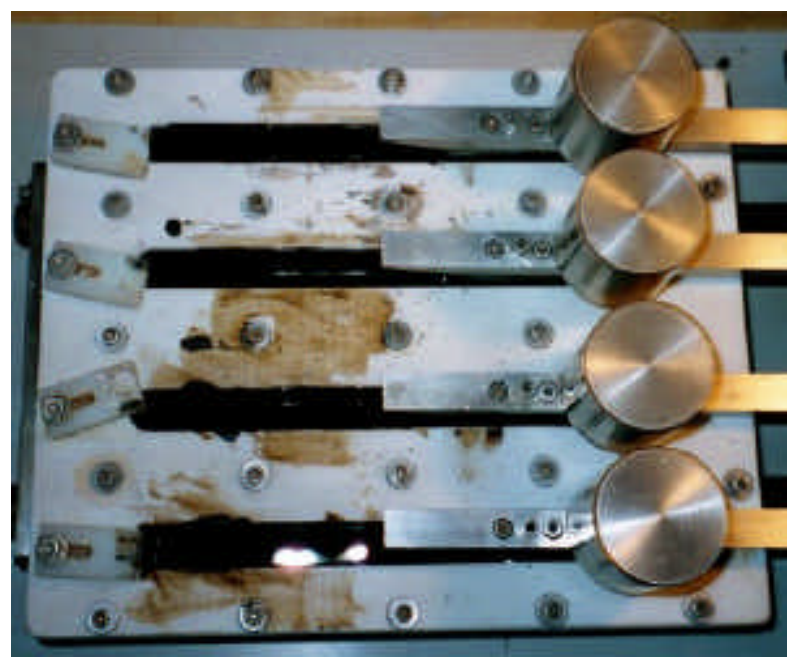

(a)

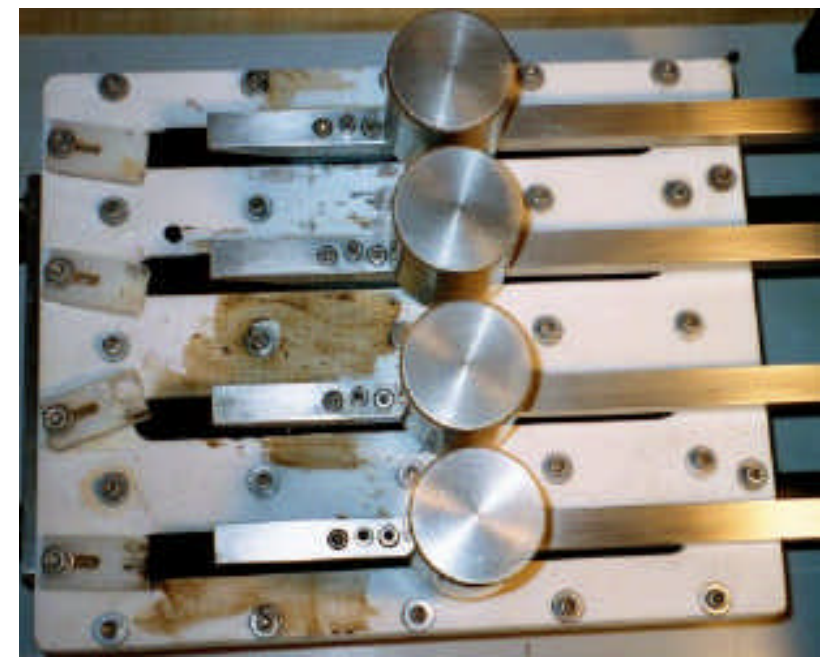

(b)

Figure 7. (a) Back stroke; (b) Forward stroke: $203 \mathrm{~mm}$ stroke length at 48 strokes per minutes 
Through years of testing, the Miller Number has been shown to be linearly dependent on a particle's hardness, Fig. $8^{\dagger}$. However, for particle size, Fig. $9^{\dagger}$ indicates that for only up to slightly more than 100 microns in diameter the $\mathrm{MN}$ is directly proportional; above that diameter the $\mathrm{MN}$ is independent of particle size. Note that, the scale in Fig. 9 is in mass loss per time, instead of the MN, but the two are equivalent since the $\mathrm{MN}$ is based on the rate of mass loss. The 16-hour period on the ordinate was the original time used to do a Miller test, however, as shown in ASTM G75-2001, a sixteen-hour test, done in four-hour increments, gave the same results as a six-hour tests, done in two-hour increments. When the Standard was originally revised in 1989 the test time interval was reduced to six hours.
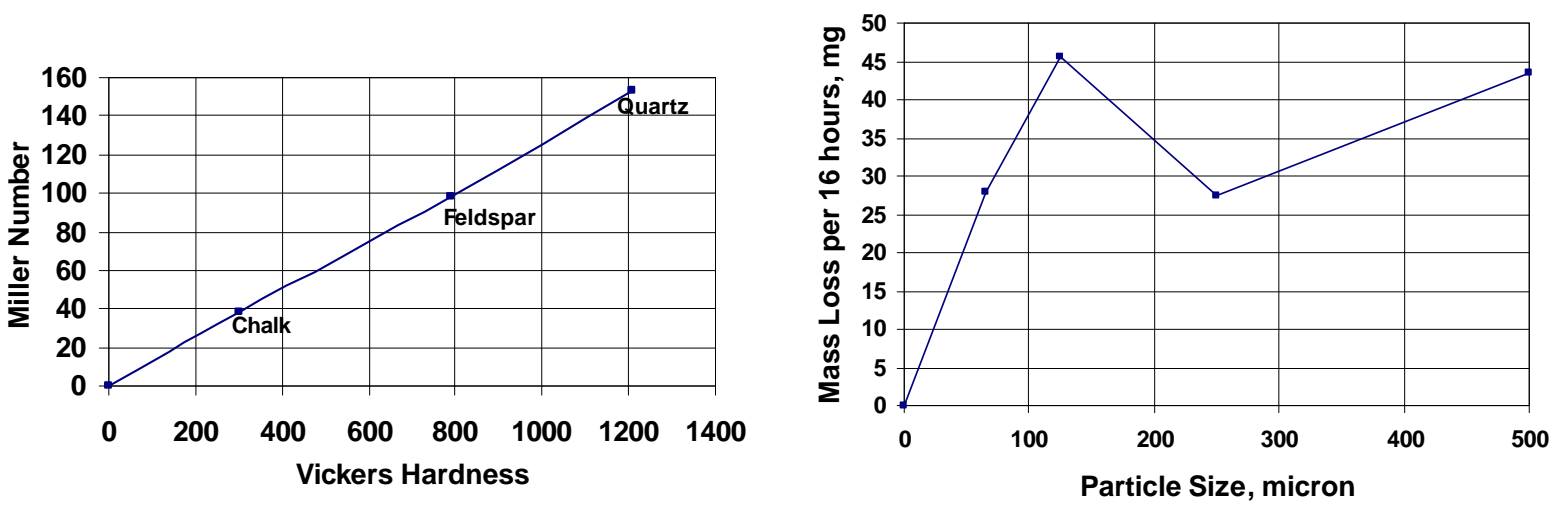

Figure 8. Effect of particle hardness on abrasivity Figure 9. Effect of particle size on abrasivity

Another important dependence exists between the $\mathrm{MN}$ and the insoluble solids concentration of a slurry. Figure $10^{\dagger}$ shows that as the solids concentration of sand in water increases to $5 \mathrm{wt} \%$, the $\mathrm{MN}$ increases rapidly, almost linearly.

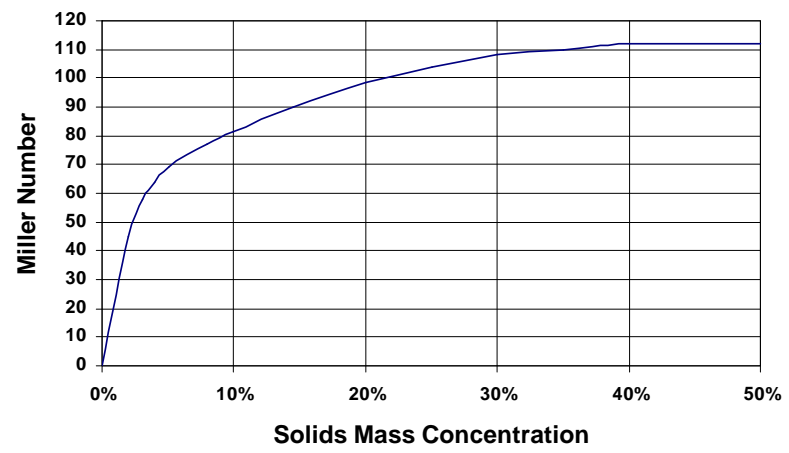

Figure 10. Effect of particle concentration on abrasivity

\footnotetext{
${ }^{\dagger}$ Figures 8, 9, and 10 were taken from Miller and Miller, 1993 [Figs 5, 6, and 8, respectively].
} 
WSRC-TR-2002-00062, Rev. 0

SRT-RPP-2002-00022, Rev. 0

After $5 \mathrm{wt} \%$ the $\mathrm{MN}$ still increases, but at a slower pace until is reaches an asymptote at approximately $40 \mathrm{wt} \%$. In fact, the abrading surface is considered saturated with particles at 20 wt $\%$, which means that additional solids do not significantly contribute to abrasion. That is, the small increase in $\mathrm{MN}$ above $20 \mathrm{wt} \%$ is considered insignificant.

\subsubsection{The Miller/SAR Numbers}

The Miller or SAR Numbers are obtained from the slope of a graph of the cumulative mass loss of a test specimen versus time. Specifically, it is taken as the slope of the curve at the two-hour point. Figure 11 show an example on how to obtain the numbers.

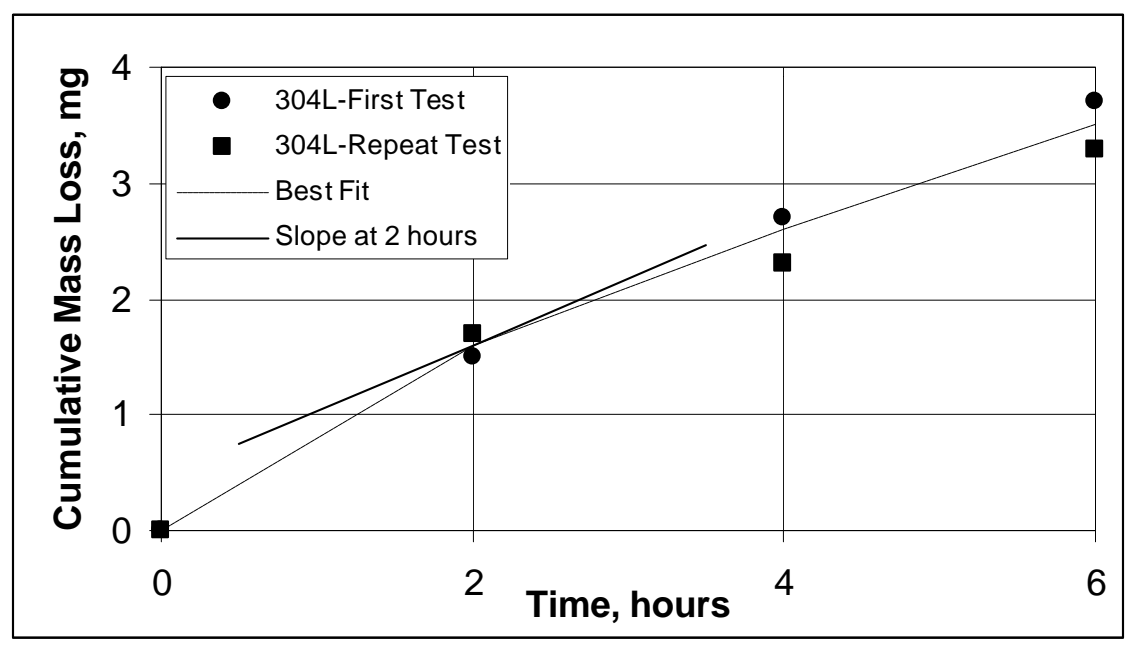

Figure 11. Determining the SAR Number

As previously explained, after each two-hour interval during a test, the specimen is removed from the test apparatus and measured for mass loss. This is done three times until six hours are completed. At the same time, another test specimen is installed in the apparatus to produce a second set of results. Both sets of results are used to develop an average set, which is then used to obtain a best fit curve to the data. However, the best fit curve is preselected to have the form of: 
WSRC-TR-2002-00062, Rev. 0

SRT-RPP-2002-00022, Rev. 0

Cumulative Mass Loss $=\mathrm{A} t^{\mathrm{B}}$

(For the example in Fig 11: $\mathrm{A} t^{\mathrm{B}}=0.9595 t^{0.72225}$ is the least squares best fit line)

The SAR Number is then obtained by finding the slope of Eq. 1, at the 2-hour point i.e.,

$\mathrm{d}\left(\mathrm{A} t^{\mathrm{B}}\right) /\left.\mathrm{dt}\right|_{t=2}=\mathrm{AB} 2^{(\mathrm{B}-1)}$

and multiplying Eq. 2 with $18.18 \times$ x ( $\left.\rho_{27 \% \text { chrome-iron }} / \rho_{\text {test speciment }}\right)$. The constant, 18.18 , makes the number relative to a slurry of sulfur and water $(\mathrm{MN}=1)$ and the ratio of the density of the standard Miller Number metal specimen of 27\% chrome-iron to the test speciment changes the Miller Number to a SAR Number. That is:

SAR Number $=18.18 \times\left(\rho_{27 \% \text { chrome-iron }} / \rho_{\text {test speciment }}\right) \times \mathrm{AB} 2^{(\mathrm{B}-1)}$

(For the example in Fig 11 Eq. 3 gives:

SAR Number $=18.18 \times(7.58 / 8.02) \times 0.9595 \times 0.722252^{(0.72225-1)}=10$

where the $\mathrm{SpG}=7.58$ for the $27 \%$ chrome-iron and 8.02 for $304 \mathrm{~L}$ metal stainless steel.)

One other number that is included in a Miller/SAR Number report is something called Attrition, or in the current version of the ASTM standard, Departure. This number quantifies the deviation of the "best fit" mass-loss curve shown in Fig. 11 from the slope of the curve at the 2-hour point. It was originally called Attrition to indicate the change in abrasivity of a particle with time. Attrition was modified to be called Departure to simply signify the departure of the two curves after two hours, which could be caused by not only particle attrition but also by the work hardening of the test specimen, which would also indicate a change of abrasivity with time. The number Departure is determined by the ratio of the curvature of the "best fit" slope of the cumulative mass loss data to the slope itself, at the 2-hour point, i.e.:

$\mathrm{D}^{2}\left(\mathrm{~A} t^{\mathrm{B}}\right) / \mathrm{dt}^{2} / \mathrm{d}\left(\mathrm{A} t^{\mathrm{B}}\right) /\left.\mathrm{dt}\right|_{t=2}=\mathrm{AB}(\mathrm{B}-1) 2^{(\mathrm{B}-2)} / \mathrm{AB} 2^{(\mathrm{B}-1)}$ 
(For the example in Fig 11 Eq. 4 gives:

$\left[0.9595 \times 0.72225 \times(0.72225-1) 2^{(0.72225-2)} / 0.9595 \times 0.72225 \times 2^{(0.72225-1)}\right] \times 100=-14 \%$

A Departure Number of - $14 \%$ indicates that the abrasivity goes down with time. That is, as seen in Fig. 11, the "best fit" curve of the cumulative mass loss data moves down, away, from the slope at the 2-hour point with time. However, this is not always the case. At times a slurrymetal combination can have positive Departure Number indicating an increase in abrasivity with time. This can happen when the abrasion breaks up relatively soft particles to release smaller, harder particles.

\subsection{Slurry Compositions and Preparation}

As already explained in the Discussion section of this report, two categories of radioactive wastes were evaluated for abrasivity, i.e., LAW and HLW. The actual slurries tested were simulants of the wastes, made to represent the physical and chemical characteristics from the best knowledge available of the makeup of the real wastes. It was important to have the simulants made to the characteristics of the waste just before they would be filtered, that is, processed to forms suitable for filtration. These forms could be either a diluted concentration of sodium, precipitated complexants, or in various stages of washing or leaching. The following is an explanation of all the recipes used to make all seven simulants, one LAW and six variations of HLW, which will be followed by analytic measurements to characterize the simulant just before being used for the wear test. Refer to Table 1 for a concise listing of the simulants. Note that the order of slurries give below is different than in Table 1 because it was convenient to group all the HLW simulants, which have the same base chemicals, after the LAW simulant, which is very different.

\subsubsection{LAW Simulant of Tank 241-AN-107 with Entrained Solids and Sr/TRU Precipitants}

This LAW simulant, which is referred to as $\mathrm{Sr}$ /TRU, was made to represents those wastes which will have both entrained and precipitated solids. For this study, a simulant of Handford tank 241AN-107 was chosen because its simulant recipe was the most developed (Eibling and Nash, 2001), which is listed in Tables $2 \mathrm{a}, 2 \mathrm{~b}$, and $2 \mathrm{c}$. It was tested at an insoluble solids concentration of $20 \mathrm{wt} \%$ to represent the slurry at its highest solids loading. (This slurry is No. 3 in Table 1). 
RPP-WTP Slurry Wear Evaluation: Slurry Abrasivity

Page 15 of 97

WSRC-TR-2002-00062, Rev. 0

SRT-RPP-2002-00022, Rev. 0

Table 2a. Recipe of $5.5 \mathrm{M} \mathrm{Na}^{+}$Supernatant for AN-107 waste simulant

\begin{tabular}{|c|c|c|c|}
\hline Volume of Feed & \multirow[b]{2}{*}{37} & \multicolumn{2}{|c|}{\begin{tabular}{l|l|l|}
80000 & $\mathrm{~mL}$ \\
\end{tabular}} \\
\hline To be mixed in a & & Gallon Pastic Tank & \\
\hline Add & grams & Actual Wt, grams & \\
\hline Water & 16000 & 16000 & \\
\hline \multicolumn{4}{|c|}{ Transition Metals and Complexing agents } \\
\hline Compounds & Formula & Mass Needed & Actual Wt, grams \\
\hline Calcium Nitrate & $\mathrm{Ca}(\mathrm{NO} 3) 2.4 \mathrm{H} 2 \mathrm{O}$ & 174.70 & 174.70 \\
\hline Cerium Nitrate & $\mathrm{Ce}(\mathrm{NO} 3) 3.6 \mathrm{H} 2 \mathrm{O}$ & 8.21 & 8.20 \\
\hline Cesium Nitrate & CsNO3 & 1.37 & 1.37 \\
\hline Copper Nitrate & $\mathrm{Cu}(\mathrm{NO} 3) 2.3 \mathrm{H} 2 \mathrm{O}$ & 5.74 & 5.74 \\
\hline Ferric Nitrate & $\mathrm{Fe}(\mathrm{NO} 3) 3.9 \mathrm{H} 2 \mathrm{O}$ & 613.37 & 613.50 \\
\hline Lanthanum Nitrate & $\mathrm{La}(\mathrm{NO} 3) 3.6 \mathrm{H} 2 \mathrm{O}$ & 7.12 & 7.13 \\
\hline Lead nitrate & $\mathrm{Pb}(\mathrm{NO} 3) 2$ & 31.12 & 31.13 \\
\hline Magnesium Nitrate & $\mathrm{Mg}(\mathrm{NO} 3) 2.6 \mathrm{H} 2 \mathrm{O}$ & 13.23 & 13.24 \\
\hline Manganous Chloride & $\mathrm{MnCl} 2.4 \mathrm{H} 2 \mathrm{O}$ & 101.75 & 101.80 \\
\hline Neodymium Nitrate & $\mathrm{Nd}(\mathrm{NO} 3) 3.6 \mathrm{H} 2 \mathrm{O}$ & 14.62 & 14.63 \\
\hline Nickel Nitrate & $\mathrm{Ni}(\mathrm{NO} 3) 2.6 \mathrm{H} 2 \mathrm{O}$ & 131.76 & 131.80 \\
\hline Potassium Nitrate & KNO3 & 231.03 & 231.20 \\
\hline Strontium Nitrate & $\mathrm{Sr}(\mathrm{NO} 3) 2$ & 0.80 & 0.81 \\
\hline Zinc Nitrate & $\mathrm{Zn}(\mathrm{NO} 3) 2.6 \mathrm{H} 2 \mathrm{O}$ & 10.34 & 10.35 \\
\hline Zirconyl Nitrate & & 9.60 & 9.61 \\
\hline EDTA & Na2EDTA & 364.17 & 364.30 \\
\hline HEDTA & HEDTA & 108.55 & 108.60 \\
\hline Sodium Gluconate & & 197.00 & 197.00 \\
\hline Glycolic Acid & & 1351.02 & 1351.00 \\
\hline Citric Acid & & 473.63 & 473.60 \\
\hline Nitrilotriacetic Acid & & 28.60 & 28.60 \\
\hline Iminodiacetic Acid & & 302.96 & 303.00 \\
\hline Boric acid & H3BO3 & 10.04 & 10.04 \\
\hline Sodium Chloride & $\mathrm{NaCl}$ & 91.25 & 91.40 \\
\hline Sodium Fluoride & $\mathrm{NaF}$ & 14.75 & 14.75 \\
\hline Sodium Chromate & $\mathrm{Na} 2 \mathrm{CrO} 4$ & 27.51 & 27.52 \\
\hline Sodium Sulfate & $\mathrm{Na} 2 \mathrm{SO} 4$ & 612.05 & 612.20 \\
\hline Potassium Molybdate & K2MoO4 & 4.46 & 4.47 \\
\hline
\end{tabular}

In separate container mix the following

\begin{tabular}{|l|l|r|r|}
\hline Add & Formula & Mass Needed & Actual Wt, grams \\
\hline Sodium Hydroxide & $\mathrm{NaOH}$ & 1267.48 & 1267.40 \\
\hline Aluminum Nitrate & $\mathrm{Al}(\mathrm{NO} 3) 3.9 \mathrm{H} 2 \mathrm{O}$ & 269.25 & 269.20 \\
\hline Sodium Phosphate & $\mathrm{Na3PO} 4.12 \mathrm{H} 2 \mathrm{O}$ & 222.90 & 223.00 \\
\hline Sodium formate & $\mathrm{NaHCOO}$ & 788.27 & 788.20 \\
\hline Sodium Acetate & $\mathrm{NaCH} 3 \mathrm{COO} .3 \mathrm{H} 2 \mathrm{O}$ & 118.87 & 118.80 \\
\hline Sodium Oxalate & $\mathrm{Na} 2 \mathrm{C} 2 \mathrm{O} 4$ & 63.09 & 63.00 \\
\hline
\end{tabular}

\begin{tabular}{|l|l|c|}
\hline Add & grams & Actual Wt, grams \\
\hline Water & 16000 & 16000.00 \\
\hline
\end{tabular}

Mix thoroughly. Then add this solution to the tared 50 Liter carboy.

\begin{tabular}{|l|l|l|l|}
\hline Add & Formula & Mass Needed & Actual Wt, grams \\
\hline Sodium Carbonate & $\mathrm{Na} 2 \mathrm{CO} 3$ & & 7437.86 \\
\hline
\end{tabular}

Mix thoroughly.

\begin{tabular}{|l|l|r|r|}
\hline Mix & Formula & Mass Needed & Actual Wt, grams \\
\hline Sodium Nitrate & NaNO3 & 14915.16 & 14915.20 \\
\hline Sodium Nitrite & NaNO2 & 4590.10 & 4590.20 \\
\hline Water & H2O & 8000 & 8000.00 \\
\hline
\end{tabular}

Add and Mix thoroughly.

\begin{tabular}{|l|l|c|c|}
\hline Add & Formula & Mass Needed & Actual Wt, grams \\
\hline Water & H2O & 24884 & 24884.00 \\
\hline \multirow{3}{*}{ Balanced Used: } & Ohaus & M\&TE\# DWB-513 & \\
& Mettler AE 163 & M\&TE \# AD-0045 & \\
Performed By: & Ohaus & M\&TE DWB-514 & \\
& Vickie William & & \\
& Mary Mose &
\end{tabular}


WSRC-TR-2002-00062, Rev. 0

SRT-RPP-2002-00022, Rev. 0

Table $2 \mathrm{~b}$. Recipe of entrained solids for AN-107 waste simulant

\section{Entrained Solids Simulant}

\begin{tabular}{|c|c|}
\hline Assumption: & \begin{tabular}{l|l}
0.5 & wt $\%$ entrained solids \\
\end{tabular} \\
\hline Density & $1.243 \mathrm{~g} / \mathrm{mL}$ \\
\hline Volume of Feed & \begin{tabular}{l|l|}
80 & Liters \\
\end{tabular} \\
\hline Total entrained solids & \begin{tabular}{l|l}
497.2 & grams \\
\end{tabular} \\
\hline
\end{tabular}

\begin{tabular}{|c|c|c|c|}
\hline & & \multirow{2}{*}{$\begin{array}{c}\text { Needed } \\
\text { grams }\end{array}$} & Used \\
\hline Recipe & Formula & & grams \\
\hline Aluminum Oxide & $\mathrm{Al}_{2} \mathrm{O}_{3}$ & 25.52 & 25.52 \\
\hline Calcium Phosphate, tribasic & $\mathrm{Ca}_{3}\left(\mathrm{PO}_{4}\right)_{2}$ & 0.36 & 0.36 \\
\hline Chromic Oxide & $\mathrm{Cr}_{2} \mathrm{O}_{3}$ & 1.90 & 1.90 \\
\hline Ferric Oxide & $\mathrm{Fe}_{2} \mathrm{O}_{3}$ & 23.72 & 23.72 \\
\hline Manganese Dioxide & $\mathrm{MnO}_{2}$ & 15.36 & 15.36 \\
\hline Sodium Aluminosilicate & $\mathrm{Na}_{2} \mathrm{O} \cdot \mathrm{Al}_{2} \mathrm{O}_{3} \cdot(\mathrm{SiO} 2)_{2} \cdot 5 \mathrm{H}_{2} \mathrm{O}$ & 8.08 & not on hand \\
\hline Sodium Oxalate & $\mathrm{Na}_{2} \mathrm{C}_{2} \mathrm{O}_{4}$ & 170.02 & 170.02 \\
\hline Sodium Carbonate Monohydrate & $\mathrm{Na}_{2} \mathrm{CO}_{3} \cdot \mathrm{H}_{2} \mathrm{Q}$ & 160.79 & 160.79 \\
\hline Sodium Fluoride & $\mathrm{NaF}$ & 24.87 & 24.87 \\
\hline Sodium Sulfate Decahydrate & $\mathrm{Na} 2 \mathrm{SO} 4.10 \mathrm{H} 2 \mathrm{O}$ & 20.55 & 20.55 \\
\hline Sodium Phosphate Dodecahydrate & $\mathrm{Na} 3 \mathrm{PO} 4.12 \mathrm{H} 2 \mathrm{O}$ & 46.03 & 46.03 \\
\hline & Total & 497.2 & \\
\hline Aluminum Oxide & $\mathrm{Al} 2 \mathrm{O} 3$ & 8.08 & 8.08 \\
\hline \multirow[t]{2}{*}{ Silica Oxide } & $\mathrm{SiO} 2$ & 16.16 & 16.16 \\
\hline & $\begin{array}{r}\begin{array}{r}\text { Substitut } \\
\mathrm{Al}_{2} \mathrm{O}_{3} \text { and } \\
\text { for Sodium Alum }\end{array} \\
\end{array}$ & ilicate & \\
\hline $\begin{array}{l}\text { Balanced Used } \\
\text { Performed By } \\
\text { Date Performed }\end{array}$ & $\begin{array}{l}\text { Mettle AE240 } \\
\text { Sammie King }\end{array}$ & \multicolumn{2}{|c|}{ M\&TE BWB-511 } \\
\hline
\end{tabular}


WSRC-TR-2002-00062, Rev. 0

SRT-RPP-2002-00022, Rev. 0

Table 2c. Recipe of precipitation additives ${ }^{\dagger}$ for $\mathrm{AN}-107$ waste simulant
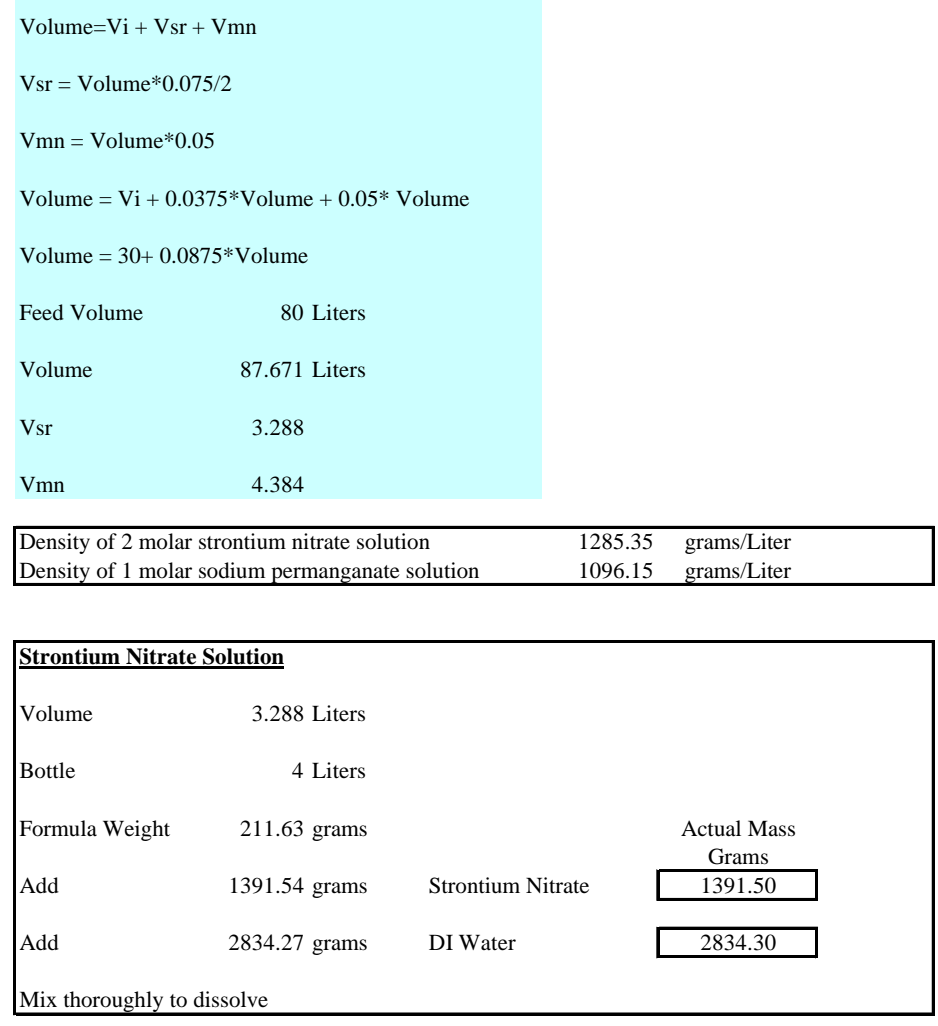

\begin{tabular}{|c|c|c|c|}
\hline \multicolumn{4}{|c|}{ Sodium Permanganate Solution } \\
\hline \multicolumn{4}{|c|}{$\begin{array}{l}\text { Sodium Permanganate Solution } \\
\text { Volume } \quad 4.384 \text { Liters }\end{array}$} \\
\hline & \multirow{3}{*}{$\begin{array}{c}\begin{array}{c}\text { Actual Mass } \\
\text { Grams }\end{array} \\
701.00 \\
\end{array}$} \\
\hline \multirow{2}{*}{$\begin{array}{l}\text { Formula Weight } \\
\text { Add }\end{array}$} & 159.94 grams & & \\
\hline & 701.11 grams & Sodium Permanganate & \\
\hline Add & 4103.93 grams & DI water & 4104.00 \\
\hline
\end{tabular}

Balance Used OHAUS M\&TE DWB-512

Performed By: Sammie King

Date Performed: $\quad 10 / 20 / 00$

\footnotetext{
${ }^{\dagger}$ Missing from Table $2 \mathrm{c}$ is the sodium hydroxide that should have been added to boost the hydroxide level to 1 Molar; it was accidentally left out during the simulant preparation. However, this fact was discovered only after carrying out the SAR test when the measured $\mathrm{pH}$ of the simulant was 10.4, instead of the expected 14. The missing hydroxide was thought not to affect the insoluble solids in the simulant, and therefore erosion, but there was a concern that the lower $\mathrm{pH}$ simulant would less corrosive. To address this error a Nonconformance report was initiated (Duignan, 2001c) and an extensive pit corrosion test was carried out by SRTC with the simulant at pH $=14$. The corrosion rate was found to be significantly less than 1 mil per year and therefore insignificant (Mickalonis, 2001).
} 


\section{$\underline{\text { Simulant Characterization }}$}

Because of the complex nature of the Sr/TRU simulant, which contains organic complexants, the order in which it is made is very important and the three tables, i.e., $2 \mathrm{a}, 2 \mathrm{~b}$, and $2 \mathrm{c}$, are in chronological order. The supernate is made first, then the entrained solids are added, then the precipitating agents. Simulant development is beyond the scope of this task, but a complete analysis of the completed simulant was done to quantify its characteristics.

Figure 12 indicates that in general the simulant is chemically similar to what is expected from the precipitated AN-107 waste. That is, the sodium level is approximately $6 \mathrm{M}$, and the strontium and lanthanum which were added in liquid form have been primarily precipitated.

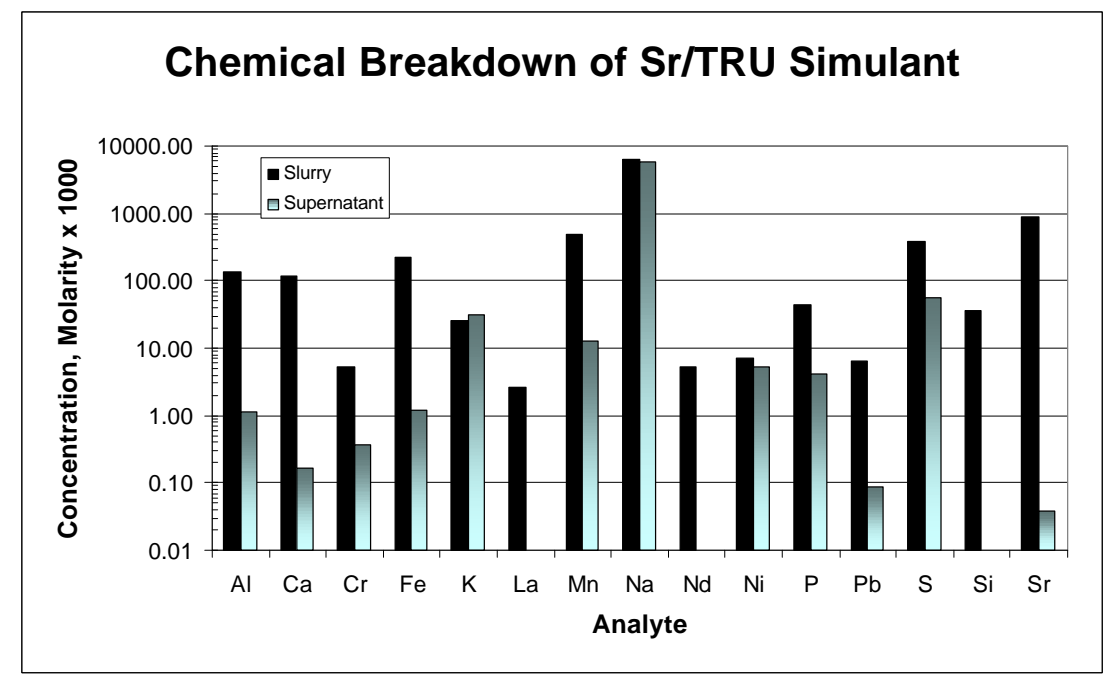

Figure 12. Concentrations of several of the important elements in the AN-107 simulant

With respect to some of the physical characteristics of the AN-107 simulant, Fig. 13, depicts its rheology (which is Fig. 1 of Hansen, 2001a). The two non-linear curves (at $25^{\circ} \mathrm{C}$ and $50^{\circ} \mathrm{C}$ ) were obtained as the shear rate was increased and they depict a thixotropic character of the precipitate at $20 \mathrm{wt} \%$ insoluble solids. The linear curves were obtained as shear rate was decreased in the viscometer, which allowed fitting a Bingham model to the data. The legend of the figure shows the Bingham models with the yield stress as the intercept. The difference in the increasing and decreasing shear rate curves is hystersis, which is not uncharacteristic of this time dependent pseudoplastic slurry. What is uncharacteristic is the increase in yield stress with increasing temperature, i.e., $22 \mathrm{~Pa}$ at $25^{\circ} \mathrm{C}$ and $42 \mathrm{~Pa}$ at $50^{\circ} \mathrm{C}$, because yield stress usually decreases with increasing temperature. This phenomenon is not explained but it was confirmed by using a different viscometer. The data shown in Fig. 13 were obtained using a concentric cylinder viscometer, but equivalent data were obtained using a spinning cone viscometer. Detail of the 
WSRC-TR-2002-00062, Rev. 0

SRT-RPP-2002-00022, Rev. 0

measurements can be found in Hansen, 2001a, but note that the measurement uncertainty of the viscometer is $\pm 3.2 \mathrm{~Pa}$.

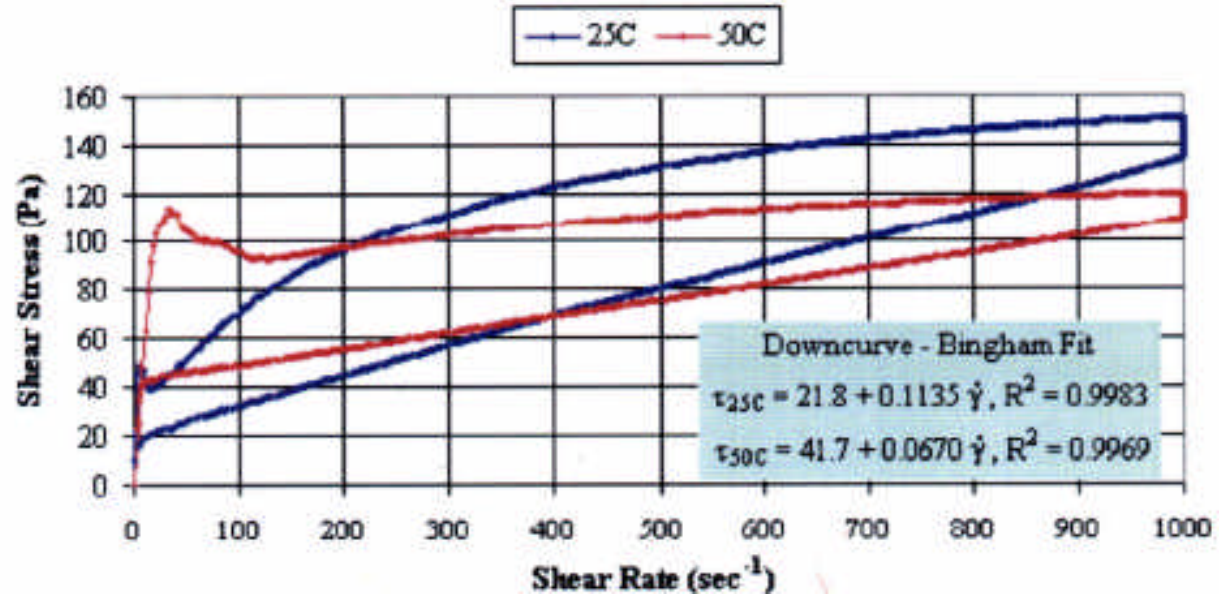

Figure 13. Rheology: Sr/TRU AN-107 simulant at $20 \mathrm{wt} \%$ insoluble solids at $25^{\circ} \mathrm{C}$ and $50^{\circ} \mathrm{C}$

Figures 14a and 14b show the distributions of the solids in the slurry before it was sent for the SAR test. Figure 14a show the volume distribution and Fig. 14b shows the number distribution (population). The actual waste has particles sizes from 1 to 40 microns, with the majority closer to 1 micron (Lumetta and Hoopes, 1999). The figures confirm that the simulant had a particle distribution similar to the real waste and, as such, is expected to elicit similar erosion characteristics.

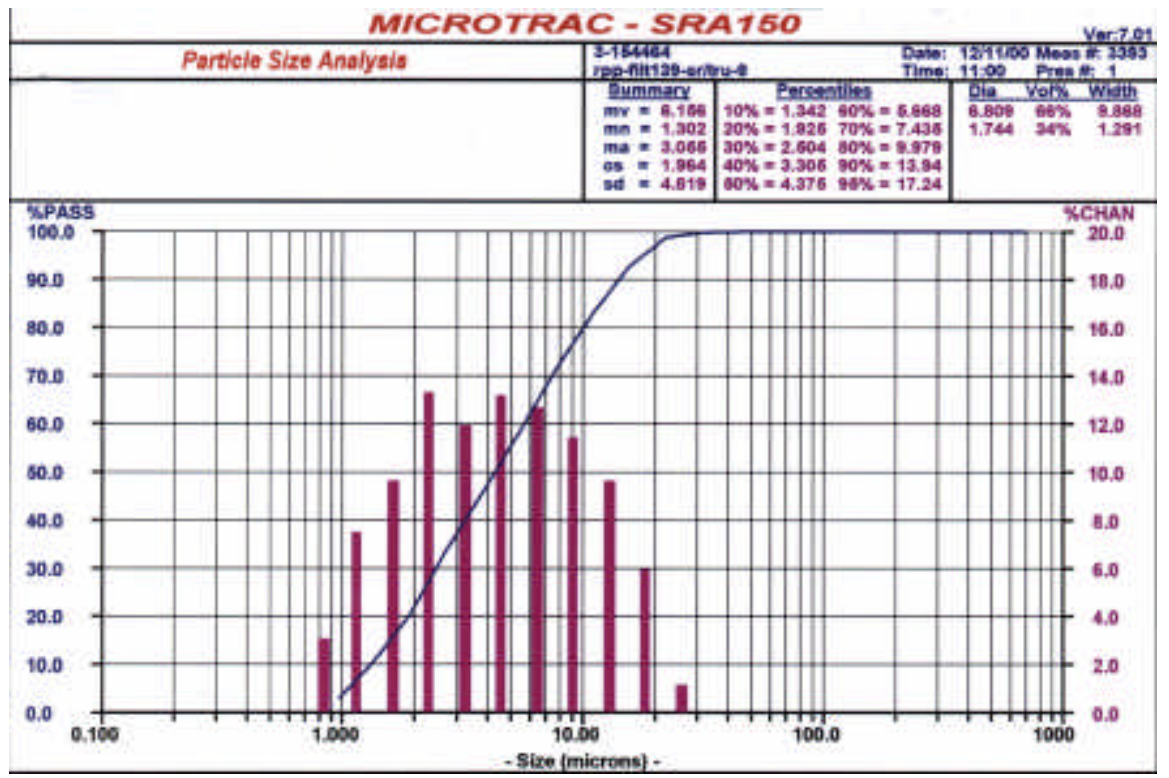

Figure 14a. Solids in the LAW simulant: AN-107, entrained solids, and Sr/TRU precipitants: Particle size distribution by Volume 
WSRC-TR-2002-00062, Rev. 0

SRT-RPP-2002-00022, Rev. 0

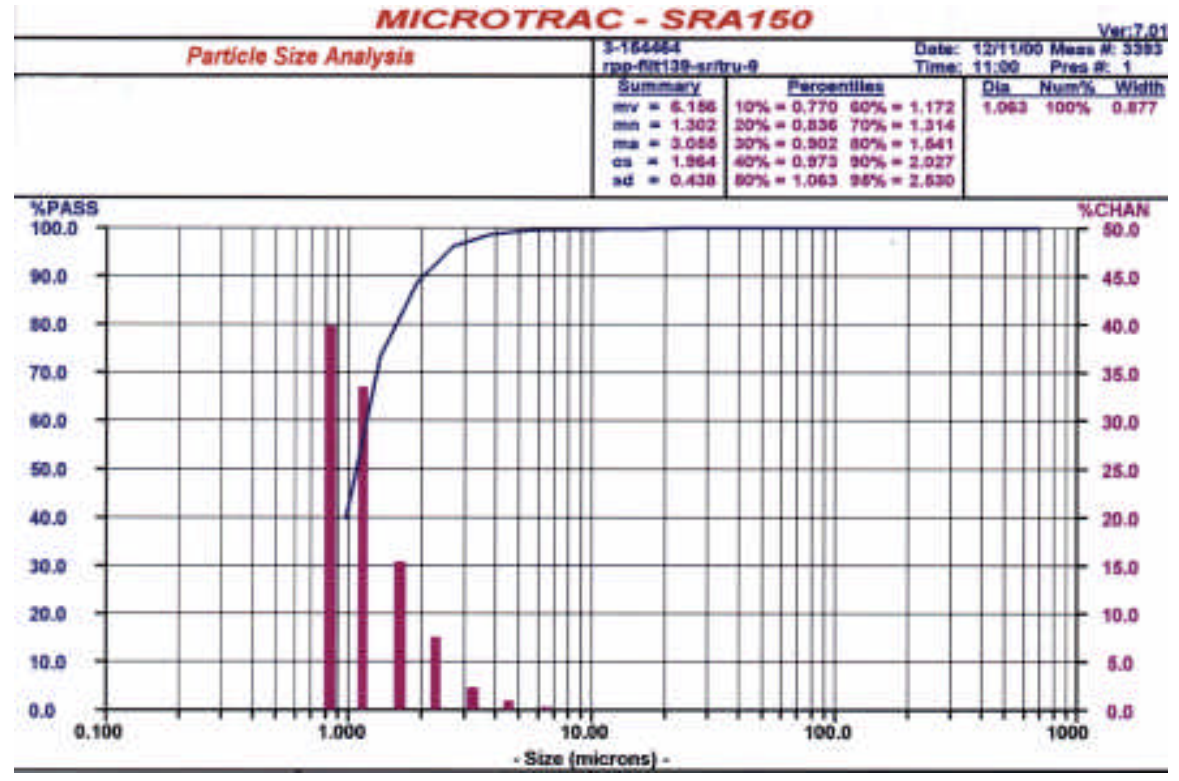

Figure 14b. Solids in the LAW simulant: AN-107, entrained solids, and Sr/TRU precipitants: Particle size distribution by Number

The highlighted data in Figs. 12 and 13, along with all other measurements made on the slurry, are given in Table A3, Appendix A.

\subsubsection{HLW Simulant of Tank 241-AZ-101}

The HLW slurry will be treated to different processes in the filtration facility, which may affect its erosive and corrosive capability. In order to capture the slurry that will cause the most wear, a simulant was made that represents the slurry as a result of each process. For all of the AZ-101 HLW simulants, the make up of the insoluble solids was the same and was based on the solids used in a simulant made for a previous (Elmore, 2000) erosion test. Table 3 lists those solids.

Table 3. Recipe of Solids used for all HLW (AZ-101) waste simulants

\section{$\underline{\text { Component }} \quad \underline{\text { Mean Particle Size* }(\mu \mathrm{m})} \quad$ \% of Total Solids}

Iron oxide A (Hematite - Fe2O3)

37

3

Iron oxide $\mathrm{B}$ (Hematite - $\mathrm{Fe} 2 \mathrm{O} 3$ )

19

31

Red iron oxide (Hematite - $\mathrm{Fe} 2 \mathrm{O} 3$ )

4

20 
WSRC-TR-2002-00062, Rev. 0

SRT-RPP-2002-00022, Rev. 0

\begin{tabular}{|c|c|c|}
\hline Alumina A (Boehmite - Al2O3) & $66 * *$ & 6.7 \\
\hline Alumina B (Gibbsite - $\mathrm{Al}(\mathrm{OH}) 3)$ & 29 & 9.4 \\
\hline Alumina $\mathrm{C}$ (Gibbsite - $\mathrm{Al}(\mathrm{OH}) 3$ ) & 10 & 6.3 \\
\hline Zirconium hydroxide (ZrO2) & 22 & 11.7 \\
\hline Silicon (Nepheline) (Na3K(AlSiO4)4) & 10 & 4.9 \\
\hline Tungsten oxide (WO3) & $* * *$ & 7 \\
\hline
\end{tabular}

* The particle sizes were determined from a volume size distribution and the mean value may differ from those listed in a previous erosion test (Elmore, 2000). However, the differences are thought to be insignificant due to the variation is particle size expected from the actual waste.

** Elmore, 2000 and Golcar, 2000 report the mean particle size of the boehmite used was 3-4 nanometers, however, the manufacturer of this substance (HiQ Alumina from Alcoa) reports that this small dimension is actually the crystallite size. It further indicates that the $\mathrm{d}_{50}=50$ microns, which matches the measured 66 microns as indicated in the Table 3.

*** The size of the Tungsten oxide used in a previous erosion test (Elmore, 2000) was given as a distribution. This effort verified that the procured compound had approximately the same size distribution (by volume), i.e.,

$\mathrm{d}<45 \mathrm{~mm}(29 \%), 45-63 \mathrm{~mm}(21 \%), 63-106 \mathrm{~mm}$ ( 37\%), > $106 \mathrm{~mm}$ (13\%); Elmore, 2000

$\mathrm{d}<44 \mathrm{~mm}(39 \%), 44-62 \mathrm{~mm}(20 \%), 62-106 \mathrm{~mm}$ ( 28\%), > $106 \mathrm{~mm}(13 \%)$; this work

Each of the next six HLW simulant will contain the solids shown in Table 3. Depending on the process of the HLW, the actual solids concentration may vary, e.g., a significant amount of alumina is expected to be dissolved after the slurry is leached.

\subsubsection{HLW Simulant AZ-101}

This slurry was made to represents neutralized current acid waste (NCAW) which contains entrained solids and may have a similar or greater corrosive effect than neutralized cladding removal wastes (NCRW); a fact shown in a previous corrosion study by Smith and Elmore, 1992. Further, the NCAW chosen to estimate its erosive/corrosive ability is that of Hanford tank 241AZ-101. This HLW was assumed to be the most aggressive because of its hard solids and a 
simulant was previously developed by PNNL (Golcar, et al., 2000) to do erosion studies (Elmore, 2000). For this study, the AZ-101 HLW simulant was tested at an insoluble solids concentration of $20 \mathrm{wt} \%$, to represent the slurry at its highest solids loading. (This slurry is No. 1 as listed in Table 1). The development of this slurry is beyond the scope of this work, but a complete description of the simulant can be found in Golcar, et at., 2000. Table 4 below lists the recipe used to make the slurry.

Table 4a. Recipe of HLW supernatant for AZ-101 waste simulant

\section{$\underline{\text { Component }(\text { volume }=5100 \mathrm{ml})}$}

Sodium hydroxide

Sodium nitrate

\section{Concentration used}

1 molar

1 molar

Table 4b. Recipe of Solids for AZ-101 waste simulant (20 wt\% insoluble solids)

\begin{tabular}{|c|c|}
\hline Component* & $\underline{\text { Amount Used }(\mathrm{g}) * *}$ \\
\hline Iron oxide $\mathrm{A}$ & 42.0 \\
\hline Iron oxide B & 434.0 \\
\hline Red iron oxide & 280.0 \\
\hline Alumina A & 93.8 \\
\hline Alumina B & 131.6 \\
\hline Alumina $\mathrm{C}$ & 88.2 \\
\hline Zirconium hydroxide & 163.8 \\
\hline Nepheline & 68.6 \\
\hline Tungsten oxide & 98.0 \\
\hline
\end{tabular}

* See Table 3 for the definitions of the compounds listed a A, B, or C.

** The absolute amounts of the solids used were such that the concentration of the combined solids resulted in $20 \mathrm{wt} \%$. The amounts of the individual components were based on the percentages used in Elmore, 2000, as shown in Table 3. 


\section{$\underline{\text { Simulant Characterization }}$}

Figure 15 indicates that the simulant has key chemical components of the AZ-101 waste. Note that, the iron and zirconium primarily stay in solid form and a high porportion of potassium and silicon stay in solid form.

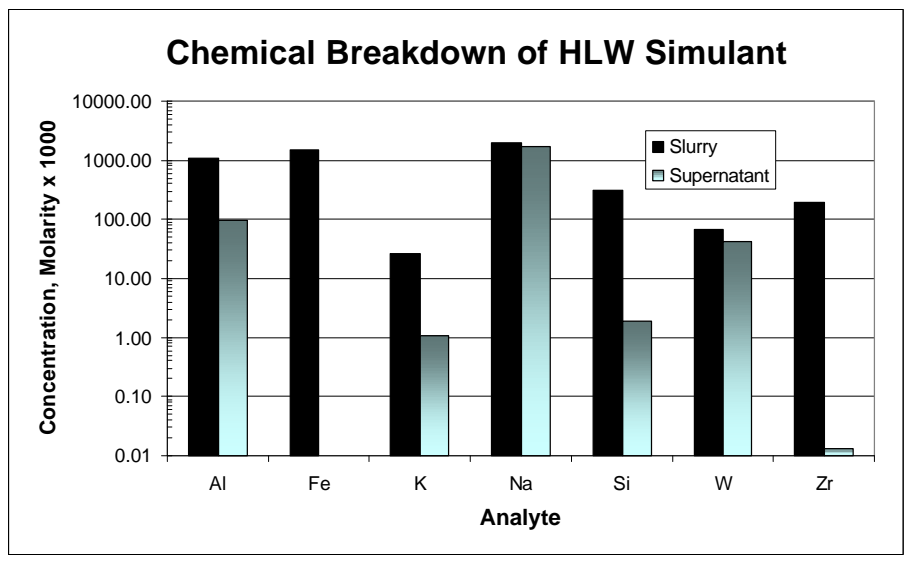

Figure 15. Concentrations of important elements in the HLW simulant

With respect to some of the physical characteristics of the AZ-101 simulant, Fig. 16, depicts its rheology (which is Fig. 1 of Hansen, 2001b). The basically linear curves in Fig. 16 indicate the Newtonian characteristics of the simulant at $20 \mathrm{wt} \%$ insoluble solids. The legend of the figure shows the viscosities obtained from the slope of the curves at $25^{\circ} \mathrm{C}$ and at $50^{\circ} \mathrm{C}$. As expected for a Newtonion fluid there was no measurable yield stress. Details of the measurements can be found in Hansen, 2001b, but note that the measurement uncertainty of the viscometer is \pm 0.89 $\mathrm{Pa}$.

To compare the rheological properties of the AZ-101 real-waste to the simulant is difficult because of the different types measuring techniques, the limited amount of available real waste samples, and the fundamental differences between real waste and simulants, as explained below. In 1989 two core samples were obtained and rheological properties were measured by Hodgson, 1995. From the second core sample, which was obtained from the tank in two segments, the shear stress versus shear rate was measured, as well as its yield stress. Rheological measurements were made on waste samples with $10 \mathrm{wt} \%$ solids and $30 \mathrm{wt} \%$ solids. Both samples were found to have pseudoplastic properties (a shear thinning slurry), however, the 10 wt\% sample showed no yield stress, while the $30 \mathrm{wt} \%$ sample had a finite yield stress ( 1.3 Pa). The rheological data were used to develop constants in a power law model to correlate the shear stress, shear rate relationships. Figure 17 includes the results of those correlations, along with a line which is a linear representation of the HLW simulant rheological properties shown in Fig. 16, up to the shear rate that was measured by Hodgson, 1995. Reasons for the differences 
WSRC-TR-2002-00062, Rev. 0

SRT-RPP-2002-00022, Rev. 0

between the rheological properties of simulant data and the real-waste data can be many, but the primary one may be due to way solids occur in the slurries.

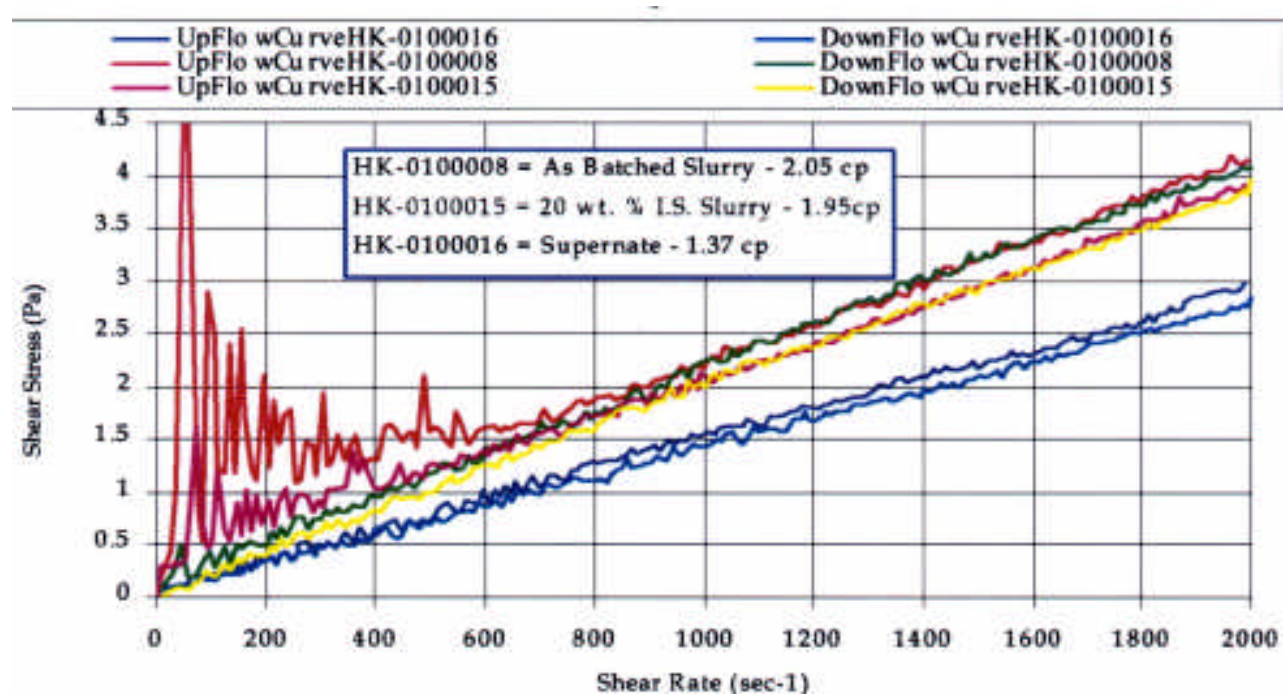

Figure 16. Rheology: AZ-101 simulant at $20 \mathrm{wt} \%$ insoluble solids at $25^{\circ} \mathrm{C}$

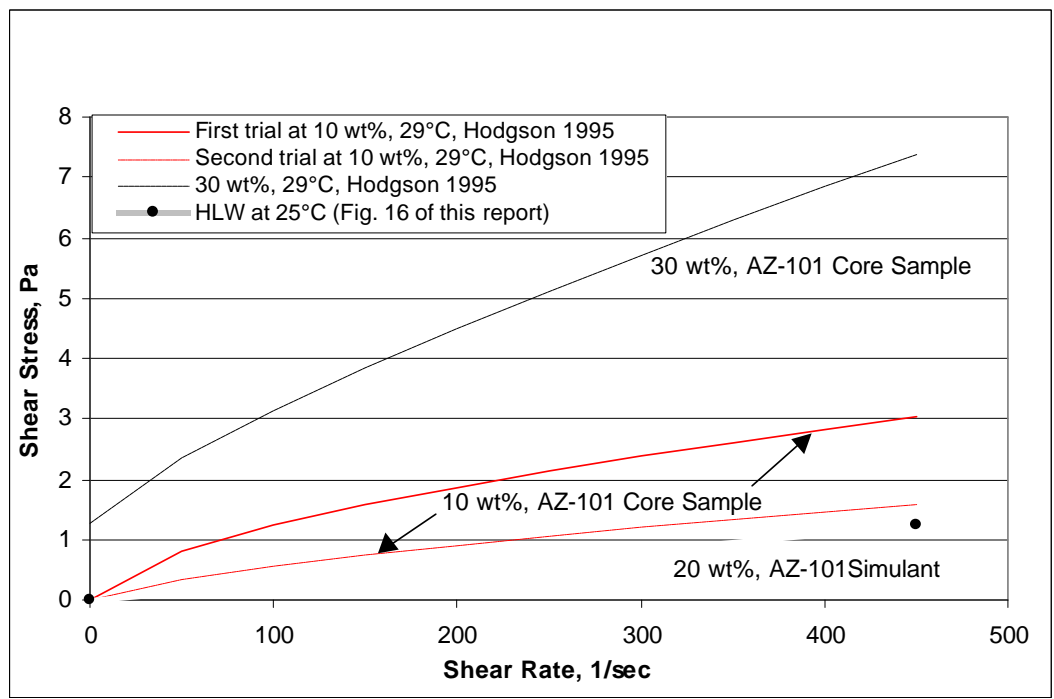

Figure 17. Rheology: AZ-101 Simulant versus 1989 real-waste samples

As seen in Fig. 17, both the AZ-101 real-waste $10 \mathrm{wt} \%$ solids and $30 \mathrm{wt} \%$ solids curves are above the AZ-101 $20 \mathrm{wt} \%$ line. This difference is thought to exist because the real waste solids are in an amorphous state, while the simulant solids are not. For the real waste the solids were 
formed from precipitation and for many years they were closely packed in the storage tank. On the other hand, the simulant was made by adding dry solids to a caustic solvent. The simulant recipe was carefully developed to match the waste chemically, as well as the morphology of the solids (Golcar, 2000). However, the solids in a slurry simulant, made by adding them dry to a liquid, may not match the amorphous phase of the real waste. Table 3-2, in Hodgson, 1995, describes the AZ-101 solids to be "soft, creamy, and sticky dark brown solids." This amorphous sticky state implies that there is considerable adhesion among the particles. The simulant solids did not appear to be sticky. As the adhesive forces among particles increase the shear stress will increase for a given shear rate The different adhesion properties can be seen from the data in Fig. 18. The settling rate for the simulant solids is approximately 12 times faster than the real waste solids, during the first 45 minutes of settling. After about 3 hours the simulant solids settled to an asymptotic height of approximately $30 \%$ of the starting solids height. Conversely, the real waste took about 2 days to approach its asymptote, and about 6 days to stop settling at a final height of $47 \%$ of its starting height. (Note, the data shown in Fig. 18 were estimated from graphs available in the two indicated sources.)

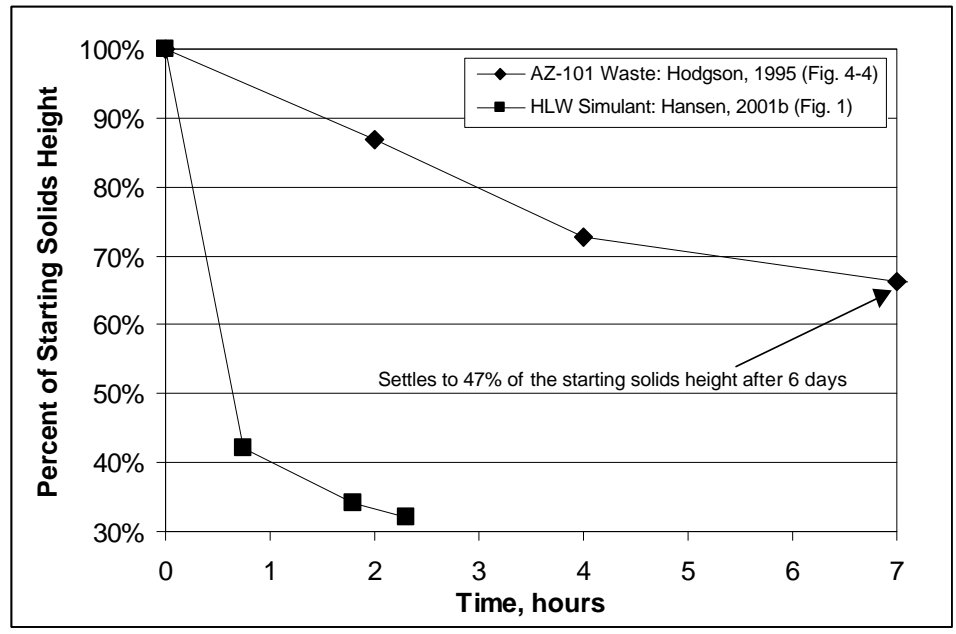

Figure 18. Solids settling rates:AZ-101 real waste composite sample vs. the HLW simulant

Fortunately, while the amorphous differences in the real waste solids to the simulant solids make matching the rheological properties difficult, they help with respect to the abrasion characteristics of the two. That is, the simulant should be conservative, i.e., more abrasive, than the real waste because the particles are distinct and individually available to participate in erosion. The sticky soft real waste particles may actually help to minimize abrasion.

Figures 19a and 19b show the distributions of the solids in the slurry before it was sent for the SAR test. Figure 19a shows the volume distribution and Fig. 19b shows the number distribution (population). The actual waste has particle sizes from 0.2 to 50 microns, with the majority closer to 1 micron (e.g., see Fig. 4.11a in Hodgson, 1995 and Fig. 3.3a in Rapko and Wagner, 1997). 
RPP-WTP Slurry Wear Evaluation: Slurry Abrasivity

WSRC-TR-2002-00062, Rev. 0

SRT-RPP-2002-00022, Rev. 0

The figures confirm that the simulant had a particle distribution similar to the real waste and as such is expected to elicit similar erosion characteristics.

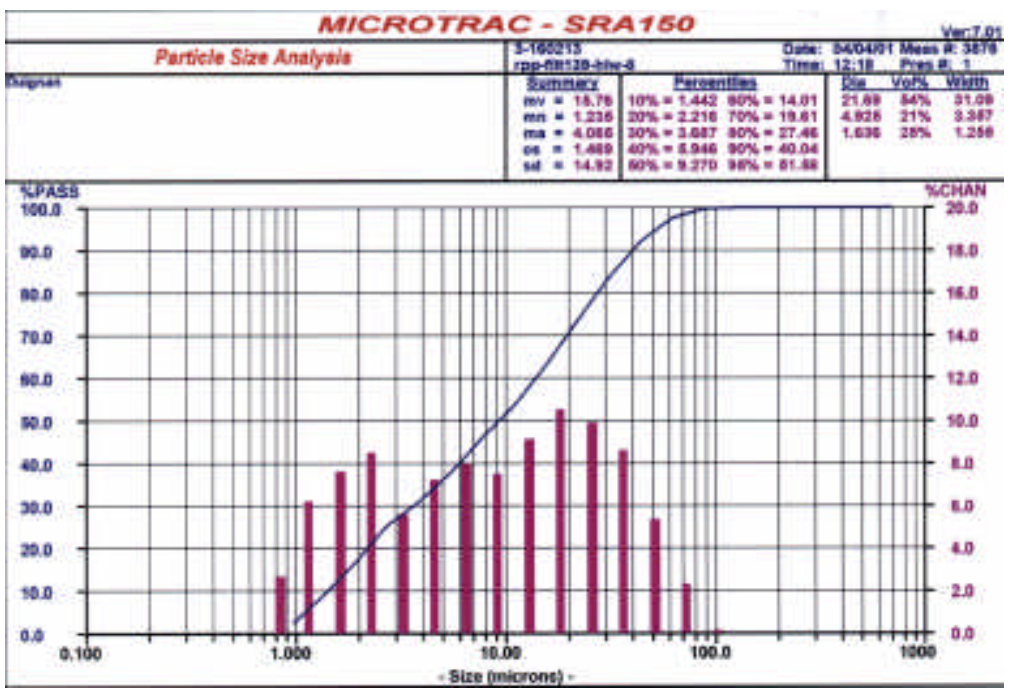

Figure 19a. Solids in the HLW simulant: AZ-101, entrained solids: Particle size distribution by Volume

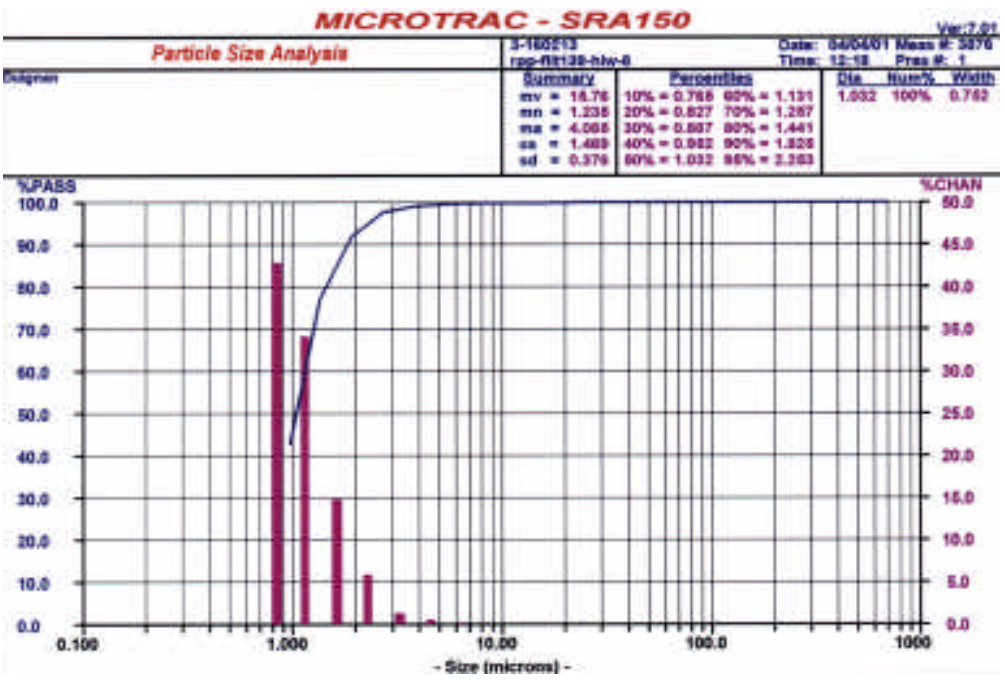

Figure 19b. Solids in the HLW simulant: AZ-101, entrained solids: Particle size distribution by Number

The highlighted data in Figs. 15 and 16, along with all other measurements made on the slurry, are given in Table A1, Appendix A. 


\subsubsection{HLW Simulant with SBS recycle}

This slurry is the same as the HLW described in Subsection 3.3.2.1 with an added slurry stream of the Submerged Bed Scrubber recycle with glass fines and glass formers, which is to come from the RPP-WTP melter offgas system. It was tested at an insoluble solids concentration of 20 wt $\%$ to represent the slurry at its highest solids loading. (This slurry is No. 2 as listed in Table 1). The development of this slurry is beyond the scope of this work, but a complete description of the HLW simulant can be found in Golcar, et at., 2000. However, the SBS recycle was added in a manner that followed the RPP flowsheet and that was available at the time this simulant was developed.

\section{$\underline{\text { Simulant Preparation }}$}

\section{SBS recycle Simulant}

The SBS recycle itself was a simulant because it was obtained from the offgas system of a pilot scale HLW melter that was operated by the $\mathrm{VSL}^{\dagger}$. Depending on the makeup of the melt, the offgas, and therefore the SBS recycle stream, may be different. The SBS recycle simulant used in this study may only be considered one candidate for the possible range of recycle streams that the pretreatment system may experience during actual plant operation. In mid-June 2001 SRTC received its shipment of SBS recycle from VSL. Some of the important features of the simulant were:

Total Solids: 0.26 to 0.28 wt\%; Insoluble Solid: 0.03 wt\%; pH: 2.9 ; density: $1.0 \mathrm{~g} / \mathrm{cc}$

These measurements indicate that the SBS recycle simulant is similar to the recycle expected from the actual HLW melter as per the current WTP flow sheet (Swanson, 2000: Table 13A, Stream 170). That is, it is made mostly of water, it is acidic, and the amount of insoluble solids is very small; the flowsheet states that it may have to be neutralized with $5 \mathrm{M}$ caustic.

In preparation to add the SBS recycle simulant to the HLW simulant it had to be neutralized, as planned for actual plant operation. The simulant was titrated with a $5 \mathrm{M} \mathrm{NaOH}$ solution until the $\mathrm{pH}$ changed from 3 to 12 . It was found that $25 \mathrm{ml}$ of caustic per liter of SBS were needed.

\footnotetext{
${ }^{\dagger}$ VSL is the Vitreous States Laboratory of The Catholic University of America located in Washington, DC and under a contract with Duratek, Inc.
} 
WSRC-TR-2002-00062, Rev. 0

SRT-RPP-2002-00022, Rev. 0

\section{HLW Simulant}

This HLW simulant is similar to the one made in the preceding Subsection except for the larger quantities. The SBS had to be added to the simulant when the concentration of entrained solids was $2.7 \mathrm{wt} \%$, as required by the RPP flowsheet (Swanson, 2000: Table a 13A, Streams 170 (SBS recycle) and 18 (HLW)). A 10-liter batch of the HLW simulant was made at a $3.3 \mathrm{wt} \%$ concentration of insoluble solids that dissolved to close to $2.7 \mathrm{wt} \%$ after mixing for two hours. The recipe used is shown in Table 5.

Table 5a. Recipe of HLW supernatant for AZ-101 waste simulant

\section{$\underline{\text { Component }(\text { volume }=10 \text { liters })}$}

Sodium hydroxide

Sodium nitrate

\section{Concentration used}

1 molar

1 molar

Table 5b. Recipe of Solids for HLW waste simulant (3.3\% insoluble solids)

\begin{tabular}{lc} 
Component* & Amount Used (g)** \\
\cline { 2 - 2 } Iron oxide A & 22.0 \\
Iron oxide B & 229.4 \\
Red iron oxide & 148.0 \\
Alumina A & 49.6 \\
Alumina B & 69.6 \\
Alumina C & 46.6 \\
Zirconium hydroxide & 86.6 \\
Nepheline & 32.3 \\
Tungsten oxide & 51.8 \\
Total Insoluble Solids & 740.0
\end{tabular}

* See Table 3 for the definitions of the compounds listed as A, B, or C.

**See Table 3 for the actual percentages of each compound. The absolute amounts of the solids used were such that the concentration of the combined solids resulted in a $2.7 \mathrm{wt} \%$. From past 
WSRC-TR-2002-00062, Rev. 0

SRT-RPP-2002-00022, Rev. 0

experience in making the HLW simulant some of the solids dissolved (especially the alumina) in the caustic solvent. Making the simulant to a certain wt $\%$ was an iterative process by assuming a necessary quantity of solids and then measuring the concentration after 2 hours of mixing, which is then followed by an adjustment (adding solids or decantation) until the desired concentration was attained.

\section{HLW with SBS recycle}

With both simulants prepared, the SBS was added to the HLW at the ratio of $1 \mathrm{~kg}$ of SBS to 8.58 $\mathrm{kg}$ of HLW at an insoluble solids concentration of $2.7 \mathrm{wt} \%$. The resulting insoluble solids concentration was approximately $2.4 \mathrm{wt} \%$, which was then decanted until the final concentration of $20 \mathrm{wt} \%$ was attained.

\section{$\underline{\text { Simulant Characterization }}$}

Figure 20 indicates key chemical components of the HLW simulant. Note that, the iron and zirconium primarily stay in solid form and a high porportion of potassium and silicon stay in solid form.

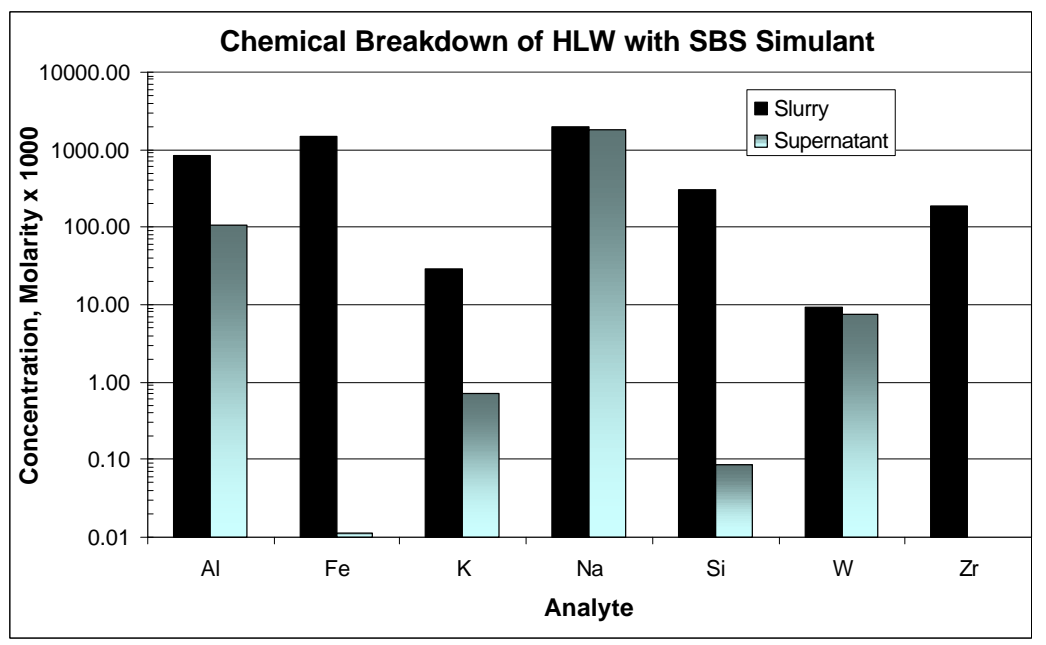

Figure 20. Concentrations of important elements in the HLWwSBS simulant

With respect to some of the physical characteristics of the simulant, Fig. 21, depicts its rheology (which was taken from Hansen, 2002). For the simulant at $20 \mathrm{wt} \%$ insoluble solids, the curves were obtained by increasing, then decreasing, the shear rate. While the curves are strictly not linear, they are considered as such for engineering purposes and when taking into account that the measurement uncertainty was $\pm 0.89 \mathrm{~Pa}$. This assumption allows the data to be fit to a Bingham model. The legend of the figure shows the Bingham models with the yield stress as the 
intercept. The difference in the increasing and decreasing shear rate curves is hystersis, which is not uncharacteristic of this time dependent pseudoplastic slurry. Detail of the measurements can be found in Hansen, 2002.

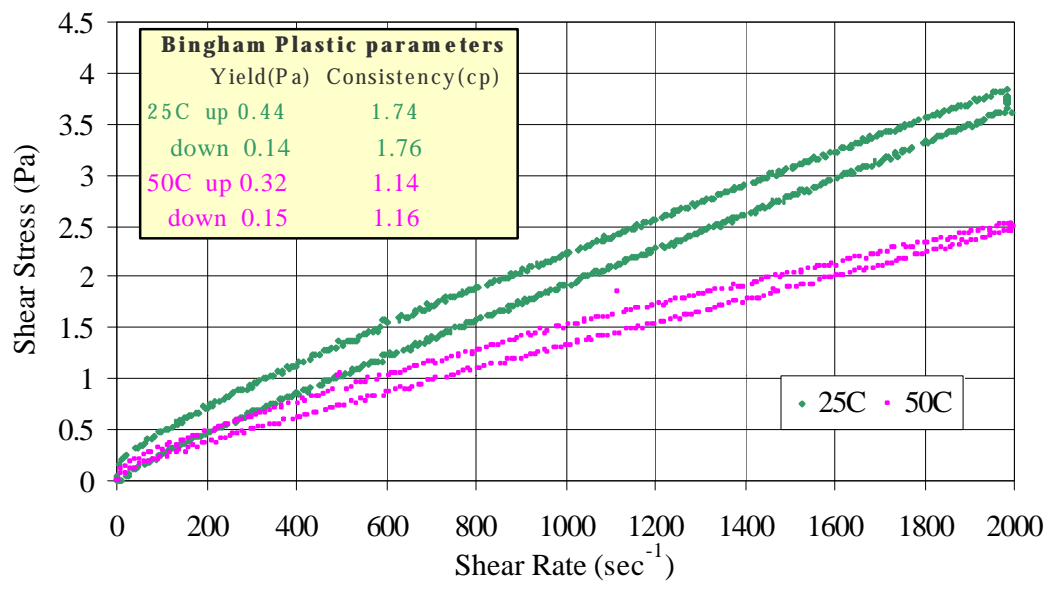

Figures $22 \mathrm{a}$ and $22 \mathrm{~b}$ show the distributions of the solids in the slurry before it was sent for the SAR test. Figure 22a show the volume distribution and Fig. 22b shows the number distribution (population). The actual waste has particle sizes from 0.2 to 50 microns, with the majority closer to 1 micron (e.g., see Fig. 4.11a in Hodgson, 1995 and Fig. 3.3a in Rapko and Wagner, 1997). The figures confirm that the simulant had a particle distribution similar to the real waste and as such is expected to elicit similar erosion characteristics.

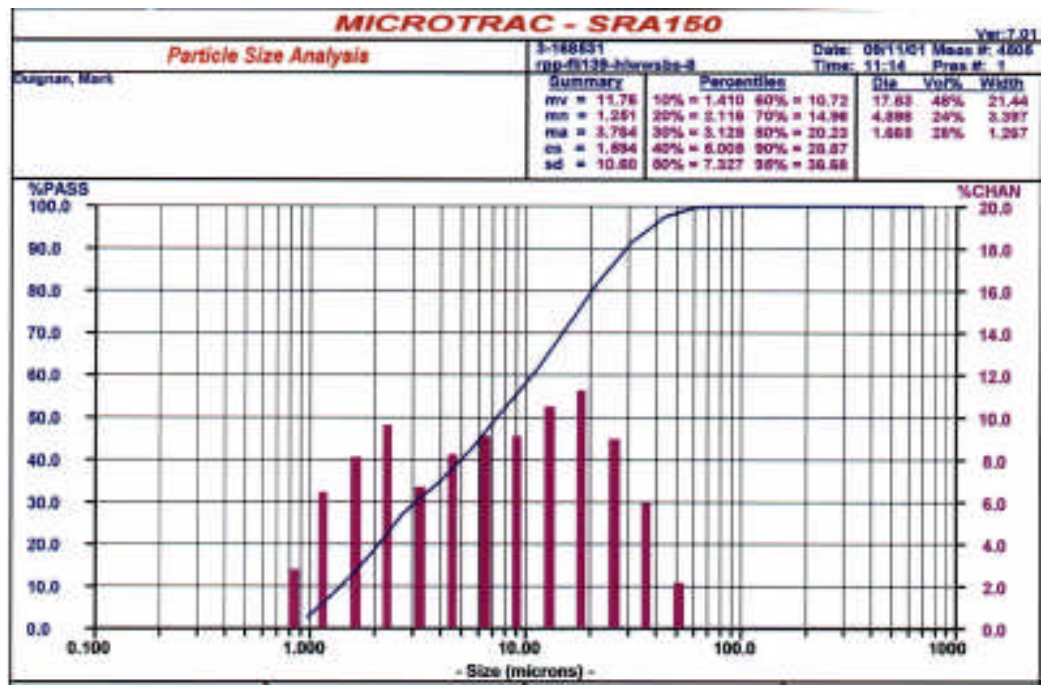

Figure 22a. Solids in the HLW with SBS simulant at $20 \mathrm{wt} \%$ insoluble solids: Particle size distribution by Volume 


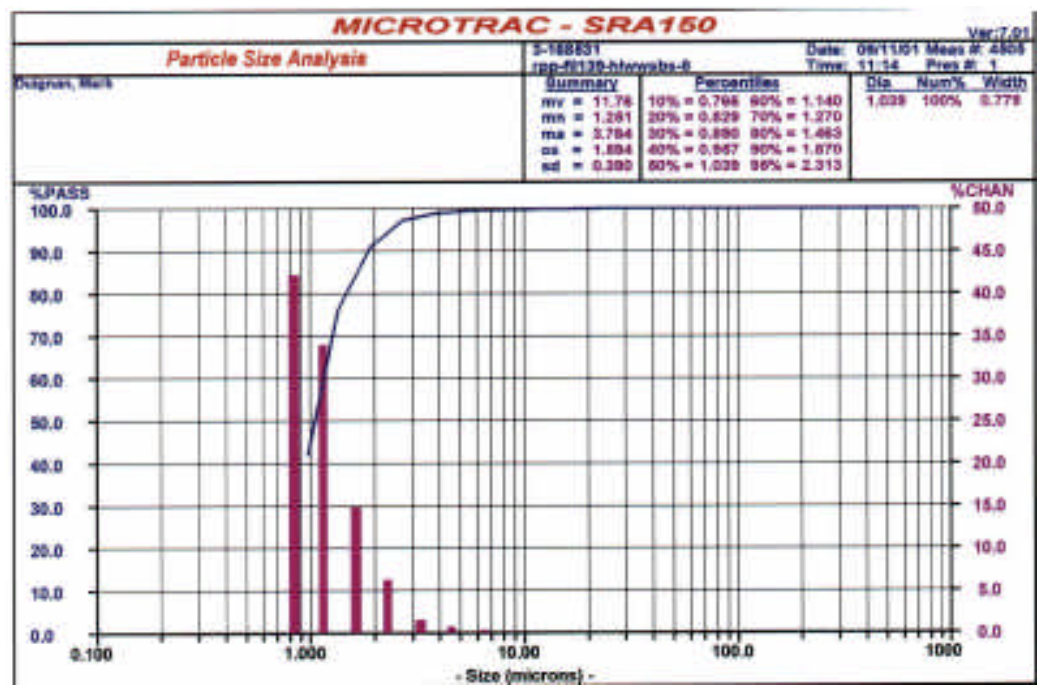

Figure 22b. Solids in the HLW with SBS simulant at $20 \mathrm{wt} \%$ insoluble solids: Particle size distribution by Number

The highlighted data in Figs. 20, and 21, along with all other measurements made on the slurry, are given in Table A2, Appendix A

\subsubsection{Leached HLW Simulant}

This slurry is the same as the HLW listed in 3.3.2.1, but then slurry it was leached at $85^{\circ} \mathrm{C}$ for 8 hours. It was tested at an insoluble solids concentration of $20 \mathrm{wt} \%$ to represent the slurry at its highest solids loading. (This slurry is No. 4 as listed in Table 1).

\section{$\underline{\text { Simulant Preparation }}$}

In the actual WTP process the HLW is to be washed with inhibited water $(0.01 \mathrm{M} \mathrm{NaOH})$ several times to remove the HLW supernatant before it is ready for leaching. The washing step was therefore not necessary to make this simulant and the dry solids were mixed directly with the leaching solvent, i.e., $3 \mathrm{M} \mathrm{NaOH}$. Knowing that some of the solids will dissolve during leaching, which was done at $85^{\circ} \mathrm{C}$, it was not necessary to start with the target insoluble solids concentration of $20 \mathrm{wt} \%$. A mass of 700 grams of solids, Table 3, was added to 2.85 liters of 3 $\mathrm{M} \mathrm{NaOH}$ and heated at $85^{\circ} \mathrm{C}$ for 8 hours. The leached slurry resulted in $10.8 \mathrm{wt} \%$ insoluble solids. Approximately 1700 grams were then removed from the leached slurry to achieve a mixture with a $20 \mathrm{wt} \%$ solids concentration. Table 6 show the quantities of compounds used. 
WSRC-TR-2002-00062, Rev. 0

SRT-RPP-2002-00022, Rev. 0

Table 6a. Recipe of HLW leaching supernatant for AZ-101 waste simulant

\section{$\underline{\text { Component }(\text { volume }=\mathbf{2 . 8 5} \text { liters })}$}

Sodium hydroxide

\section{Concentration used}

3 molar

Table 6b. Recipe of Solids for AZ-101 waste simulant (18\% insoluble solids)

\begin{tabular}{lc} 
Component* & Amount Used (g)** \\
\cline { 2 - 3 } Iron oxide A & 21.0 \\
Iron oxide B & 217.0 \\
Red iron oxide & 140.0 \\
Alumina A & 46.9 \\
Alumina B & 65.8 \\
Alumina C & 44.1 \\
Zirconium hydroxide & 81.9 \\
Nepheline & 34.3 \\
Tungsten oxide & 49.0 \\
Total Insoluble Solids & 700.0
\end{tabular}

* See Table 3 for the definitions of the compounds listed as A, B, or C and for the actual percentages of each compound.

** The absolute amounts of the solids created a slurry with starting solids concentration of 18 wt $\%$, which was reduced to $10.8 \mathrm{wt} \%$ due to leaching. After leaching the concentration was increased to $20 \mathrm{wt} \%$ 
RPP-WTP Slurry Wear Evaluation: Slurry Abrasivity

WSRC-TR-2002-00062, Rev. 0

SRT-RPP-2002-00022, Rev. 0

\section{$\underline{\text { Simulant Characterization }}$}

Figure 23 indicates the key chemical components of the leached HLW simulant. Note that, the iron and zirconium primarily stay in solid form and a high porportion of silicon stays in solid form.

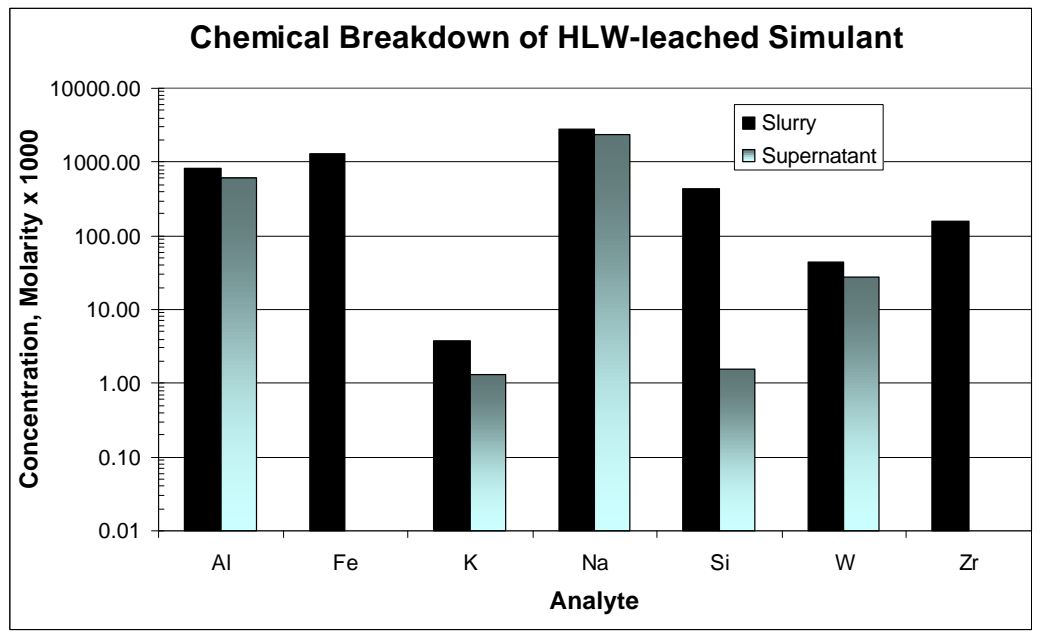

Figure 23. Concentrations of important elements in the leached HLW simulant

With respect to some of the physical characteristics of the simulant, Fig. 24, is a measure of the slurry's rheology (which is Fig. 3 in Wilkinson, 2001b). The basically linear curves obtained indicate the Newtonian characteristics of the simulant at $20 \mathrm{wt} \%$ insoluble solids. The viscosities were obtained from the slope of the curves and found be: $3.1 \mathrm{cp}$ at $25^{\circ} \mathrm{C}$ and $1.9 \mathrm{cp}$ at $50^{\circ} \mathrm{C}$.

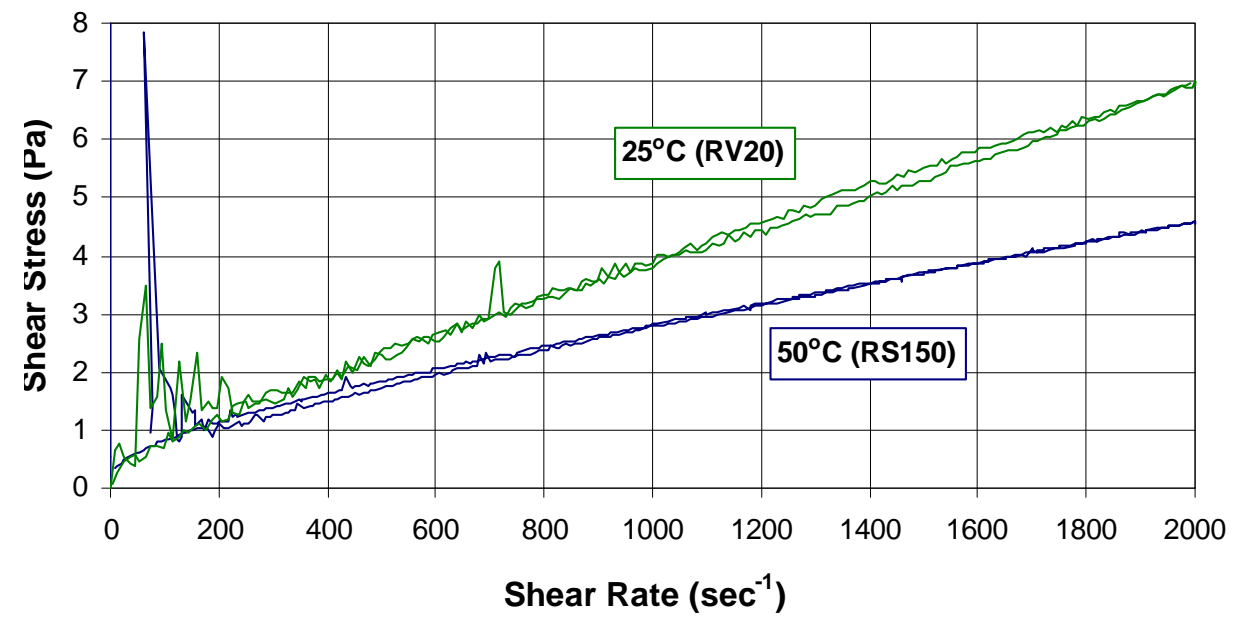

Figure 24. Rheology: leached HLW at $20 \mathrm{wt} \%$ insoluble solids at $25^{\circ} \mathrm{C}$ and $50^{\circ} \mathrm{C}$ 
Stating a viscosity implies the slurry acts as a Newtonian fluid, but Figure 24 indicates that the curves do not go exactly through the origin which implies that the slurry is strictly nonNewtonian. There was a very small yield stress between $0.6 \mathrm{~Pa}$ and $1 \mathrm{~Pa}$, however because of the measurement uncertainty for the data was $\pm 0.89 \mathrm{~Pa}$, this stress is not significant. Furthermore, a close look of the overall shear stress vs. shear rate indicate that the slurry is a pseudoplastic nonNewtonian fluid. For engineering purposes it may be acceptable to treat the slurry as a simple Newtonian fluid since the non-linear curvature is very slight and within the measurement uncertainty of the viscometers. Details of the measurements can be found in Wilkenson, 2001b.

Figures $25 \mathrm{a}$ and $25 \mathrm{~b}$ show the distributions of the solids in the slurry before it was sent for the SAR test. Figure 25a show the volume distribution and Fig. 25b shows the number distribution (population). The actual waste has particles sizes from 0.2 to 50 microns, with the majority closer to 1 micron (e.g., see Fig. 4.11a in Hodgson, 1995 and Fig. 3.3a in Rapko and Wagner, 1997). The figures confirm that the simulant had a particle distribution similar to the real waste and as such is expected to elicit similar erosion characteristics.

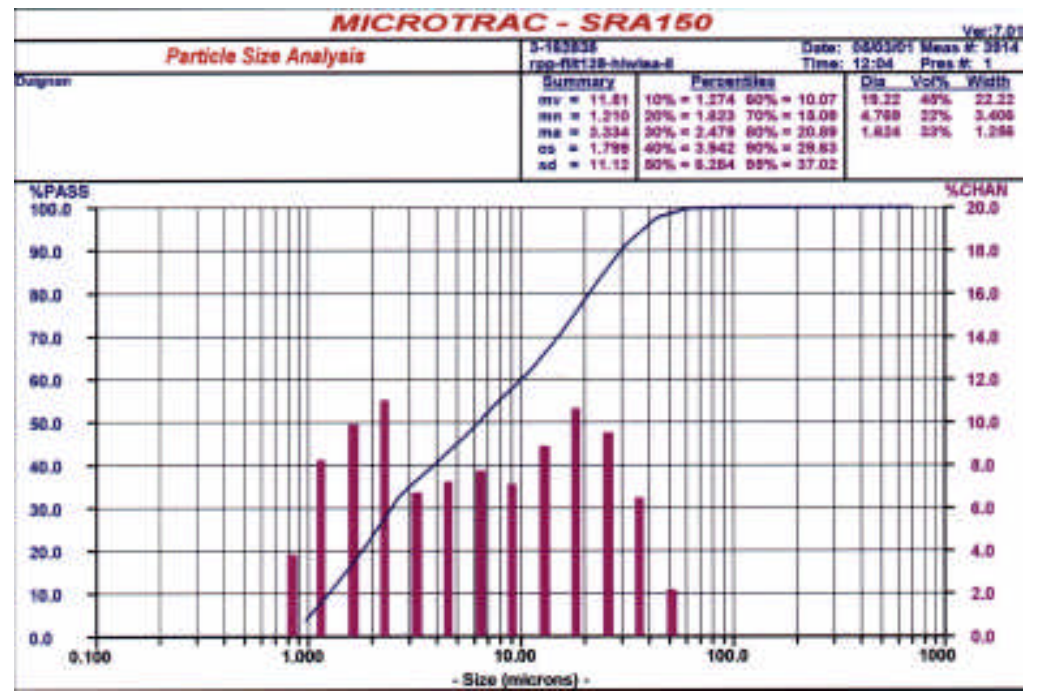

Figure 25a. Solids in the HLW leached simulant: AZ-101, entrained solids: Particle size distribution by Volume 
WSRC-TR-2002-00062, Rev. 0

SRT-RPP-2002-00022, Rev. 0

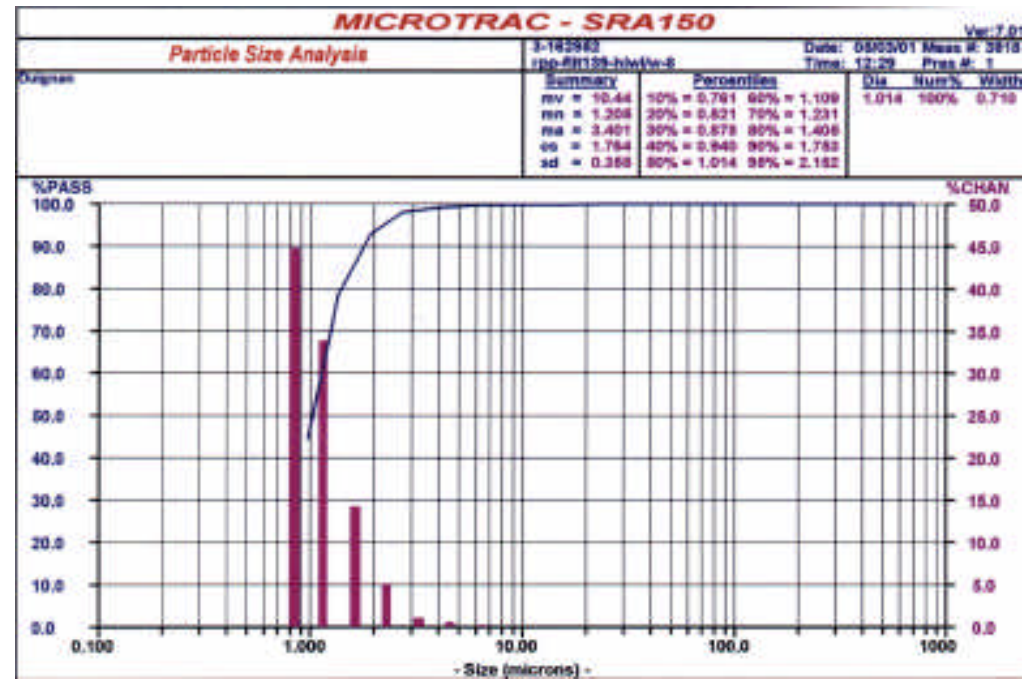

Figure 25b. Solids in the HLW leached simulant: AZ-101, entrained solids: Particle size distribution by Number

The highlighted data in Figs. 23 and 24, along with all other measurements made on the slurry, are given in Table A5, Appendix A.

\subsubsection{Washed HLW Simulant}

This slurry is the same as the HLW listed in 3.3.2.1, but then the slurry was washed with inhibited water $(0.01 \mathrm{M} \mathrm{NaOH})$ at $25^{\circ} \mathrm{C}$. It was tested at an insoluble solids concentration of 20 wt\% to represent the slurry at its highest solids loading. (This slurry is No. 6 as listed in Table 1).

\section{$\underline{\text { Simulant Preparation }}$}

In the actual WTP process the HLW is to be washed with inhibited water $(0.01 \mathrm{M} \mathrm{NaOH})$ several times to remove the HLW supernatant before it is ready for leaching. Since the washed slurry will be concentrated before leaching begins, in order to make room in the preparation tank for the leaching solution, the filtration system will experience flows of washed slurry. This simulant is to determine the abrasivity of only the washed slurry. The RPP flow sheet indicates multiple washings to remove interstitial HLW supernatant, which may also dissolve some of the solids. To be more conservative this simulant was simple made by adding the dry solids, Table $7 \mathrm{~b}$, so that the resulting mixture contained $20 \mathrm{wt} \%$ insoluble solids. To make the mixture 500 grams of dry solids were added to 2 liters of inhibited water, mixed for 16 hours, then its solids concentration was verified to be $20 \mathrm{wt} \%$. 
WSRC-TR-2002-00062, Rev. 0

SRT-RPP-2002-00022, Rev. 0

Table 7a. Recipe of washed HLW supernatant for AZ-101 waste simulant

\section{Component $(2000 \mathrm{ml})$}

Sodium hydroxide

\section{Concentration used}

0.01 molar

Table 7b. Recipe of Solids for AZ-101 waste simulant (20 wt\% insoluble solids)

Component*

Iron oxide A

Iron oxide B

Red iron oxide

Alumina A

Alumina B

Alumina C

Zirconium hydroxide

Nepheline

Tungsten oxide

Total Insoluble Solids

\section{$\underline{\text { Amount Used (g)* }}$}

15.0

155.0

100.0

33.5

47.0

31.5

58.5

24.5

35.0

500.0

* See Table 3 for the definitions of the compounds listed as A, B, or C and for the actual percentages of each compound.

Simulant Characterization

Figure 26 indicates the key chemical components of the washed HLW simulant. Note that, most of the added solids did not dissolve in the inhibited water. 
WSRC-TR-2002-00062, Rev. 0

SRT-RPP-2002-00022, Rev. 0

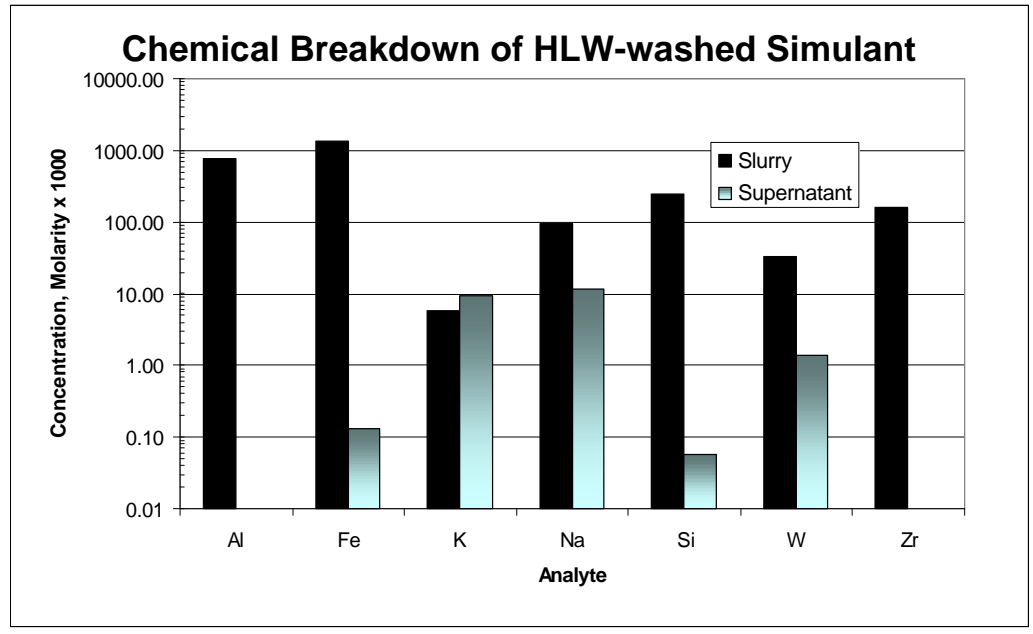

Figure 26. Concentrations of important elements in the washed HLW simulant

With respect to some of the physical characteristics of the simulant, Fig. 27 shows a measure of its rheology (which is Fig. 2 in Wilkinson, 2001b). The basically linear curves indicate the Newtonian characteristics of the simulant at $20 \mathrm{wt} \%$ insoluble solids. The viscosities were obtained from the slope of the curves were found to be: $1.8 \mathrm{cp}$ at $25^{\circ} \mathrm{C}$ and $0.8 \mathrm{cp}$ at $50^{\circ} \mathrm{C}$. Stating a viscosity implies the slurry acts as a Newtonian fluid, and within the uncertainty of the measurement $( \pm 0.89 \mathrm{~Pa})$ this is true. Details of the measurements can be found in Wilkenson, $2001 b$.

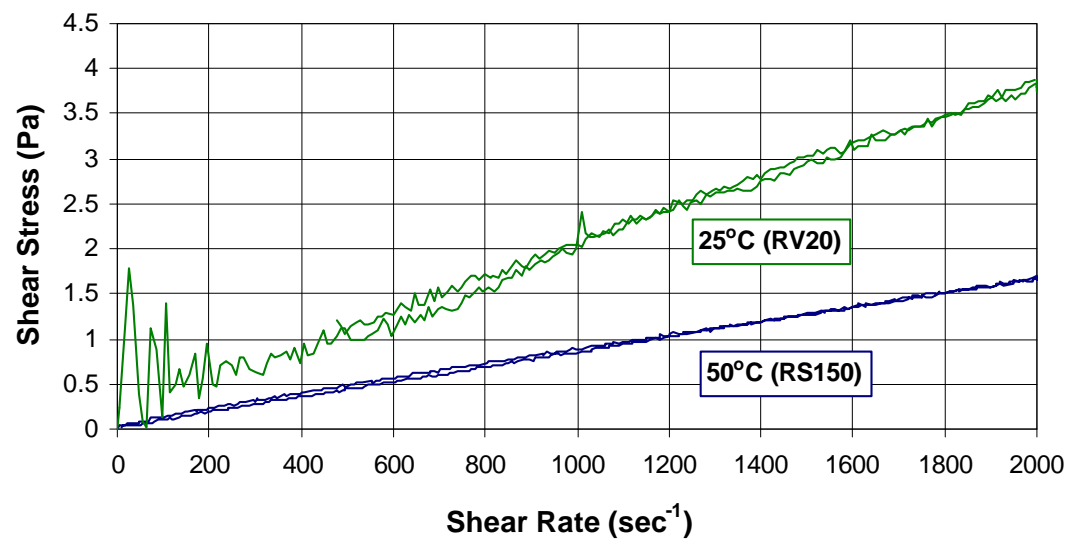

Figure 27. Rheology: washed HLW at $20 \mathrm{wt} \%$ insoluble solids at $25^{\circ} \mathrm{C}$ and $50^{\circ} \mathrm{C}$

Figures $28 \mathrm{a}$ and $28 \mathrm{~b}$ show the distributions of the solids in the slurry before it was sent for the SAR test. Figure $28 \mathrm{a}$ show the volume distribution and Fig. $28 \mathrm{~b}$ shows the number distribution 
(population). The actual waste has particles sizes from 0.2 to 50 microns, with the majority closer to 1 micron (e.g., see Fig. 4.11a in Hodgson, 1995 and Fig. 3.3a in Rapko and Wagner, 1997). The figures confirm that the simulant had a particle distribution similar to the real waste and as such is expected to elicit similar erosion characteristics.

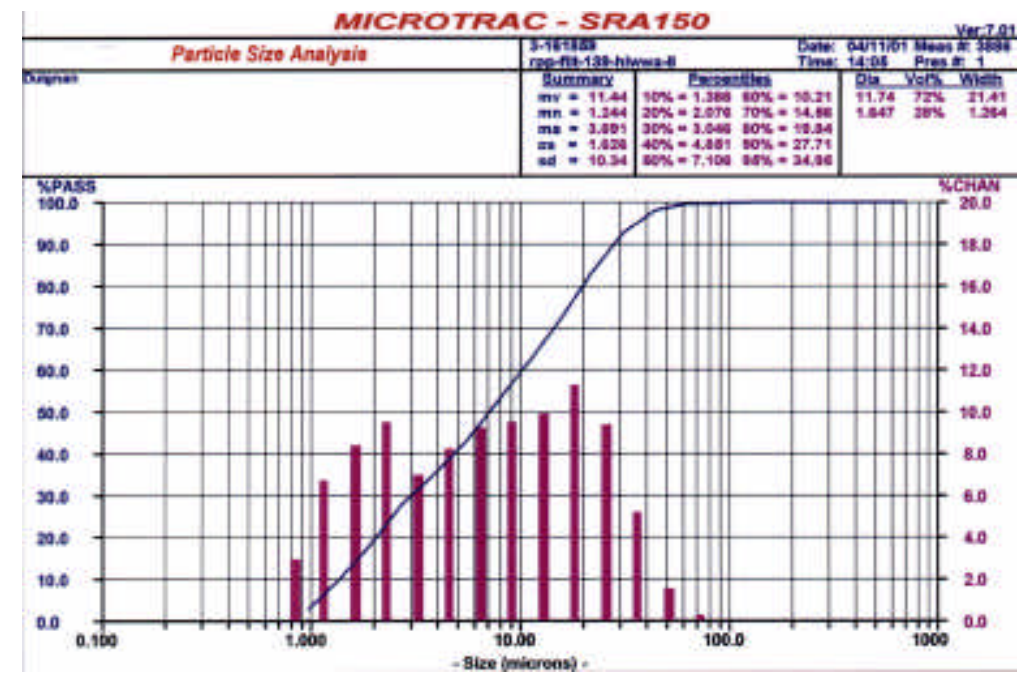

Figure 28a. Solids in the HLW washed simulant: AZ-101, entrained solids: Particle size distribution by Volume

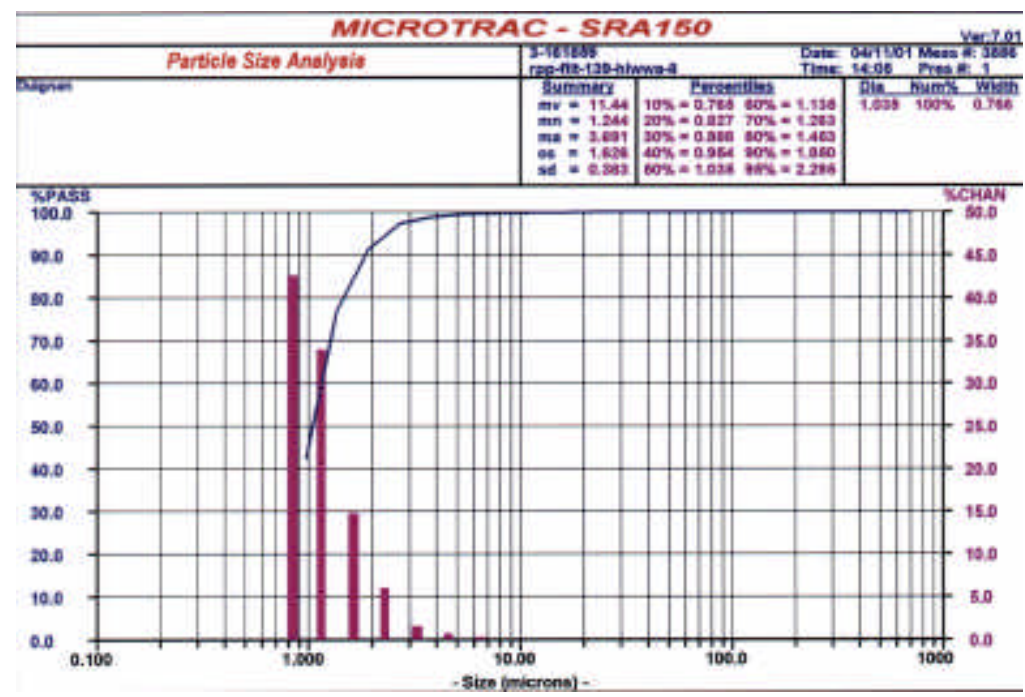

Figure 28b. Solids in the HLW washed simulant: AZ-101, entrained solids: Particle size distribution by Number

The highlighted data in Figs. 26 and 27, along with all other measurements made on the slurry, are given in Table A6, Appendix A. 
WSRC-TR-2002-00062, Rev. 0

SRT-RPP-2002-00022, Rev. 0

\subsubsection{Washed \& Leached HLW Simulant with SBS recycle}

This slurry is the same as the HLW with SBS recycle described in Subsection 3.3.2.2, which was then washed and leached. It was tested at an insoluble solids concentration of $20 \mathrm{wt} \%$ to represent the slurry at its highest solids loading. (This slurry is No. 5 as listed in Table 1)

\section{$\underline{\text { Simulant Preparation }}$}

\section{SBS recycle Simulant}

See subsection 3.3.2.2 for an explanation of SBS recycle. For this simulant a quantity of 103.3 grams of $5 \mathrm{M} \mathrm{NaOH}$ was added to 3998 grams of SBS recycle to raise its $\mathrm{pH}$ from 3 to 12 , as per the RPP flow sheet. That is, this titration resulted in adding approximately $22 \mathrm{~mL}$ of $5 \mathrm{M} \mathrm{NaOH}$ per liter of SBS, which is close to the $25 \mathrm{~mL} /$ liter used for the SBS pH adjustment in subsection 3.3.2.2 (slurry number 2). The difference between the two adjustment amounts can be attributed to the uncertainties in $\mathrm{pH}$ probes.

\section{HLW Simulant}

This HLW simulant is similar to the one made in the subsection 3.3.2.1 except that the quantities are different because the SBS recycle had to be added while HLW concentration of entrained solids was $2.7 \mathrm{wt} \%$. The resulting mixture was then washed with $0.01 \mathrm{M} \mathrm{NaOH}$ and the leached with $3 \mathrm{M} \mathrm{NaOH}$. A 30-liter batch of the HLW simulant and the recipe used is shown in Table 8.

Table 8a. Recipe of HLW supernatant for AZ-101 waste simulant

\section{Component}

For HLW simulant

[volume $=30$ liters $(32640$ grams $)$ ]

Sodium hydroxide

Sodium nitrate

For Washing simulant

$[3 \times$ volume $=11.8$ liters $(11760$ grams $)]$

Sodium hydroxide

For Leaching simulant

\section{Concentration used}

1 molar

1 molar
0.01 molar 
WSRC-TR-2002-00062, Rev. 0

SRT-RPP-2002-00022, Rev. 0

[volume $=3.9$ liters $(4357$ grams $)$ ]

Sodium hydroxide 3 molar

Table $8 b$. Recipe of Solids for HLW waste simulant (3.3\% insoluble solids)

\begin{tabular}{lc} 
Component* & Amount Used (g)** \\
\cline { 2 - 2 } Iron oxide A & 33.3 \\
Iron oxide B & 344.1 \\
Red iron oxide & 222.0 \\
Alumina A & 77.4 \\
Alumina B & 104.4 \\
Alumina C & 69.9 \\
Zirconium hydroxide & 129.9 \\
Nepheline & 54.4 \\
Tungsten oxide & 77.7 \\
\hline Total Insoluble Solids & 1110.1
\end{tabular}

* See Table 3 for the definitions of the compounds listed as A, B, or C.

**See Table 3 for the actual percentages of each compound. The absolute amounts of the solids used were such that the concentration of the combined solids resulted in a $2.7 \mathrm{wt} \%$. From past experience in making the HLW simulant some of the solids dissolved (especially the alumina) in the caustic solvent. Making the simulant to a certain wt $\%$ was an iterative process by assuming a necessary quantity of solids and then measuring the concentration after 2 hours of mixing, which is then followed by an adjustment (adding solids or decantation) until the desired concentration was attained.

HLW with SBS recycle

With both simulants prepared, the SBS was added to the HLW at the ratio of $1 \mathrm{~kg}$ of SBS to 8.58 $\mathrm{kg}$ of HLW at an insoluble solids concentration of $2.7 \mathrm{wt} \%$ (The actual amounts used were 3911 grams of SBS to 33557 grams of HLW simulant). The resulting insoluble solids concentration was approximately $2.4 \mathrm{wt} \%$, which was then centrifuged and decanted to increase the solids' 
concentration to $20 \mathrm{wt} \%$ before being washed. The remaining slurry had a total mass of 4702 grams.

\section{Washing: HLW with SBS recycle}

As per the RPP-WTP flow sheet the slurry was washed 3 times with $0.01 \mathrm{M} \mathrm{NaOH}$, inhibited water. The slurry was washed at $25^{\circ} \mathrm{C} \pm 5^{\circ} \mathrm{C}$ with a volume of inhibited water that is, at least, three times the volume of the HLW with SBS recycle at $20 \mathrm{wt} \%$ in solids. The amount of inhibited water used was 11760 grams. After washing for 2 hours, the slurry was concentrated back to its original volume. The washing process was repeated two more times. That is, after each washing, 11760 grams of liquid were removed and replaced with 11760 grams of inhibited water.

\section{Leaching:Washed HLW with SBS recycle}

After washing, the slurry mixture was concentrated to at least $20 \mathrm{wt} \%$ and then a volume of $3 \mathrm{M}$ $\mathrm{NaOH}$ was added that equal, at least, three times the settled volume of the solids. In this case, the washed slurry was centrifuged and all standing supernatant decanted. What remained were 1282 grams of wet solids that had an approximate volume of $650 \mathrm{~mL}$. Six times this volume of 3 $\mathrm{M}$ caustic was added (i.e., 3.9 liters) and then the mixture was agitated at $80^{\circ} \mathrm{C}$ for 8 hours. The reason that six volumes were used was to ensure there would be enough slurry after leaching and concentration to $20 \mathrm{wt} \%$ to perform the SAR tests. The resulting solids concentration turned out to be: $33 \mathrm{wt} \%$ total solids and $19.5 \mathrm{wt} \%$ insoluble solids. The final volume was 2.8 liters, which is based on a measured density of $1.343 \mathrm{~g} / \mathrm{mL}$.

\section{$\underline{\text { Simulant Characterization }}$}

Figure 29 indicates the key chemical components of the washed and leached HLW simulant. Note that, the iron and zirconium primarily stay in solid form and a high porportion of silicon stays in solid form.

With respect to some of the physical characteristics of the simulant, Fig. 30, depicts its rheology (which was taken from Hansen, 2002). For the simulant at $20 \mathrm{wt} \%$ insoluble solids, the curves were obtained as shear rate was increased and then decreased in the viscometer. To facilitate the use of the data, they were correlated to a Bingham model, which assumes a linear shear stress versus shear rate relation with a finite yield stress. While the data do not exactly follow a linear relationship, they are close enough for engineering purposes and the variance is within the uncertainty of the measurements, i.e., 0.89 Pa. The legend of the figure shows the Bingham models with the yield stress as the intercept. The difference in the increasing and decreasing shear rate curves is hystersis, which is not uncharacteristic of this time dependent pseudoplastic slurry. Detail of the measurements can be found in Hansen, 2002. 
WSRC-TR-2002-00062, Rev. 0

SRT-RPP-2002-00022, Rev. 0

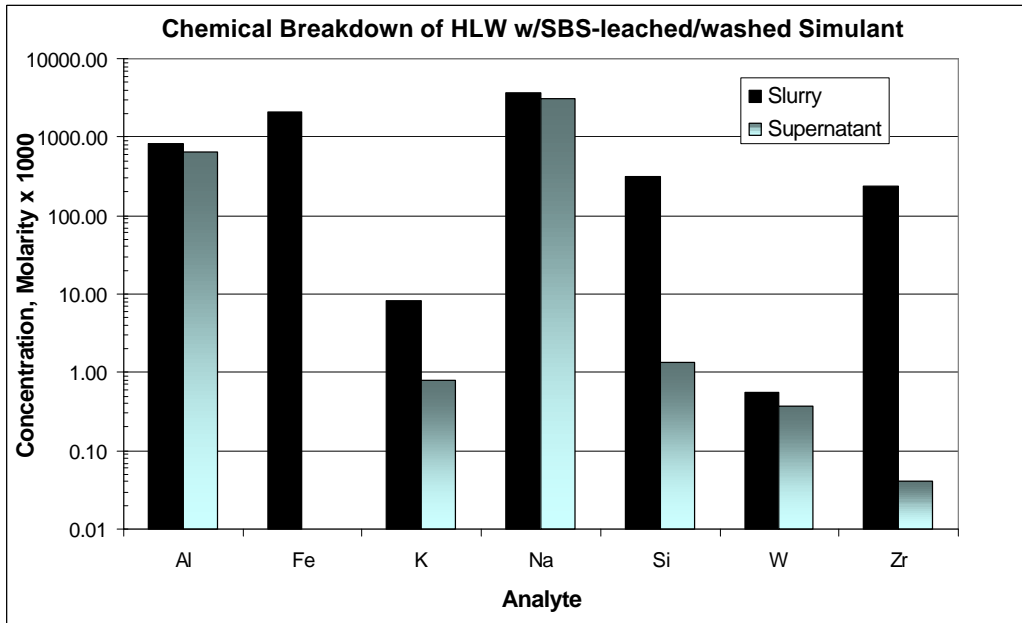

Figure 29. Concentrations of important elements in the washed > leached HLWwSBS simulant

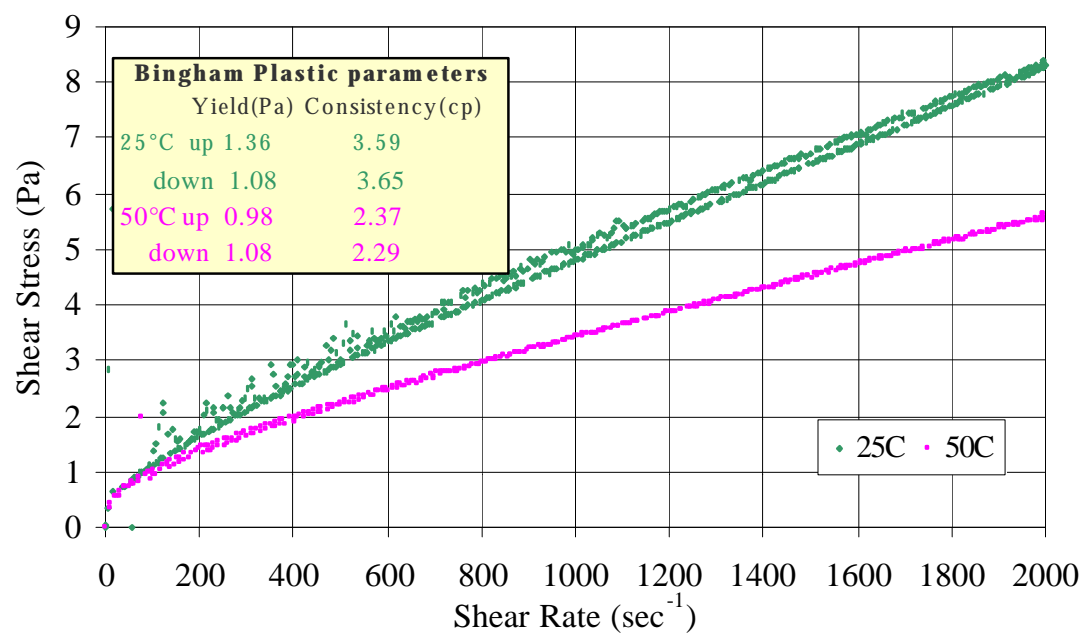

Figure 30. Rheology: washed and leached HLW with SBS recycle at $20 \mathrm{wt} \%$ insoluble solids at $25^{\circ} \mathrm{C}$ and $50^{\circ} \mathrm{C}$

Figures 31a and 31b show the distributions of the solids in the slurry before it was sent for the SAR test. Figure 31a show the volume distribution and Fig. 31b shows the number distribution (population). The actual waste has particle sizes from 0.2 to 50 microns, with the majority closer to 1 micron (e.g., see Fig. 4.11a in Hodgson, 1995 and Fig. 3.3a in Rapko and Wagner, 1997). The figures confirm that the simulant had a particle distribution similar to the real waste and as such is expected to elicit similar erosion characteristics. 
WSRC-TR-2002-00062, Rev. 0

SRT-RPP-2002-00022, Rev. 0

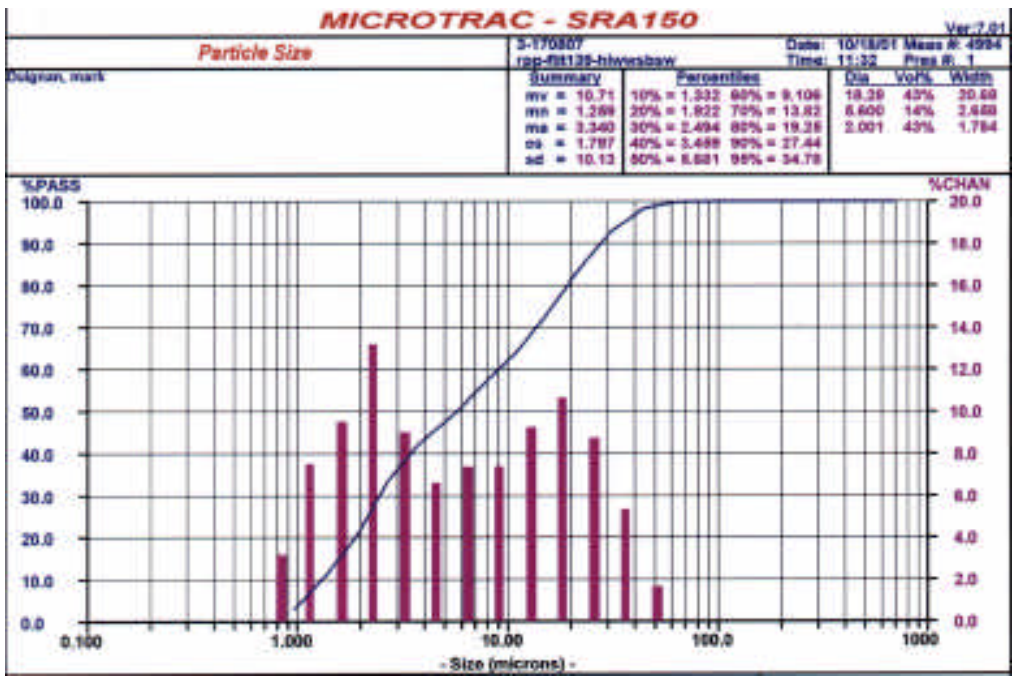

Figure 31a. Solids in the leached and washed HLW with SBS simulant at 20 wt $\%$ insoluble solids: Particle size distribution by Volume

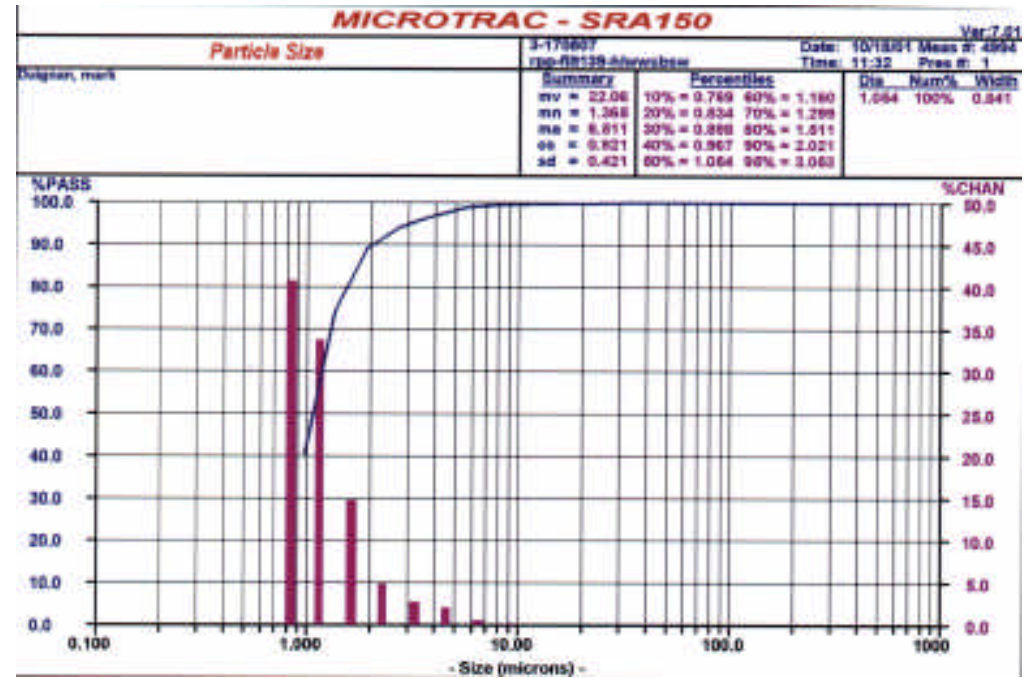

Figure 31b. Solids in the leached and washed HLW with SBS simulant at $20 \mathrm{wt} \%$ insoluble solids: Particle size distribution by Number

The highlighted data in Figs. 29, and 30, along with all other measurements made on the slurry, are given in Table A5, Appendix A

\subsubsection{Leached \& Washed HLW Simulant}

This slurry is the same as the leached HLW listed in 3.3.2.3, but after leaching the slurry was washed twice with $0.01 \mathrm{M} \mathrm{NaOH}$. (This slurry is No. 7 as listed in Table 1). 
WSRC-TR-2002-00062, Rev. 0

SRT-RPP-2002-00022, Rev. 0

\section{$\underline{\text { Simulant Preparation }}$}

As in the actual WTP process, the HLW was washed with inhibited water $(0.01 \mathrm{M} \mathrm{NaOH})$ several times at $25^{\circ} \mathrm{C}$ to remove the HLW supernatant before it was ready for leaching. After leaching the $\mathrm{HLW}$ at $85^{\circ} \mathrm{C}$ and concentrating the solids, the mixture was washed again, but at $85^{\circ} \mathrm{C}$ for 8 hours (and this final wash was to be done twice). Knowing that some of the solids would dissolve during the $85^{\circ} \mathrm{C}$ leaching, the solids concentration was started at approximately $27 \mathrm{wt} \%$ before leaching, Table $9 \mathrm{~b}$. That is, 1000 grams of solids were mixed with $2400 \mathrm{ml}$ of 3 $\mathrm{M} \mathrm{NaOH}$ for 8 hours, then they were separated from the supernatant by centrifuging. To the remaining $678 \mathrm{ml}$ of wet solids, $2715 \mathrm{ml}$ (a 4:1 volume ratio) of $0.01 \mathrm{M} \mathrm{NaOH}$ were added to wash the mixture for 8 hours at $85^{\circ} \mathrm{C}$. The centrifugation and washing process was repeated once and then the final mixture was concentrated to $20 \mathrm{wt} \%$ insoluble solids. The actual concentration was measured to be $21.5 \mathrm{wt} \%$. Being over $20 \mathrm{wt} \%$, the concentration was considered acceptable because it would be conservative.

Table 9a. Recipe of HLW leaching supernatant for AZ-101 waste simulant

\section{Component}

Sodium hydroxide $($ volume $=2400 \mathrm{ml})$

Sodium hydroxide (volume $=2715 \mathrm{ml} \mathrm{x} \mathrm{2)}$

\section{Concentration used}

3 molar

0.01 molar

Table 9b. Recipe of Solids for AZ-101 waste simulant

\section{$\underline{\text { Component* }} \quad \underline{\text { Amount Used (g)* }}$}

Iron oxide A

30.0

Iron oxide $\mathrm{B}$

310.0

Red iron oxide

200.0

Alumina A

67.0

Alumina B

94.0

Alumina $\mathrm{C}$

63.0

Zirconium hydroxide

117.0

Nepheline 
Tungsten oxide

Total Insoluble Solids
70.0

1000.0

* See Table 3 for the definitions of the compounds listed as A, B, or C and for the actual percentages of each compound.

\section{$\underline{\text { Simulant Characterization }}$}

Figure 32 indicates the key chemical components of the leached HLW simulant. Note that, the iron, silicon, and zirconium primarily stay in solid form.

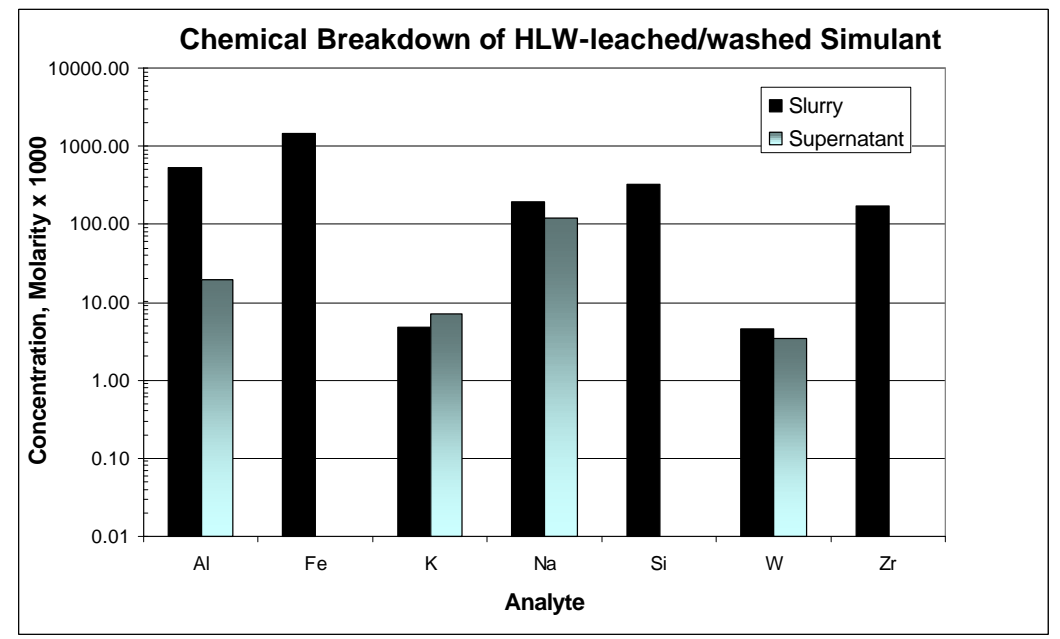

Figure 32. Concentrations of important elements in the leached HLW simulant

With respect to some of the physical characteristics of the simulant, Fig. 33, depicts its rheology (which is Fig. 4 in Wilkinson, 2001b). The basically linear curves indicate the Newtonian characteristics of the simulant at $20 \mathrm{wt} \%$ insoluble solids. The viscosities were obtained from the slope of the curves and were found be: $1.6 \mathrm{cp}$ at $25^{\circ} \mathrm{C}$ and $0.8 \mathrm{cp}$ at $50^{\circ} \mathrm{C}$ for the slurry. Stating a viscosity implies the slurry acts as a Newtonian fluid, and within the uncertainty of the measurement $( \pm 0.89 \mathrm{~Pa})$. Details of the measurements can be found in Wilkenson, $2001 \mathrm{~b}$.

Figures 34a and 34b show the distributions of the solids in the slurry before it was sent for the SAR test. Figure 34a show the volume distribution and Fig. 34b shows the number distribution (population). The actual waste has particles sizes from 0.2 to 50 microns, with the majority 
closer to 1 micron (e.g., see Fig. 4.11a in Hodgson, 1995 and Fig. 3.3a in Rapko and Wagner, 1997). The figures confirm that the simulant had a particle distribution similar to the real waste and as such is expected to elicit similar erosion characteristics.

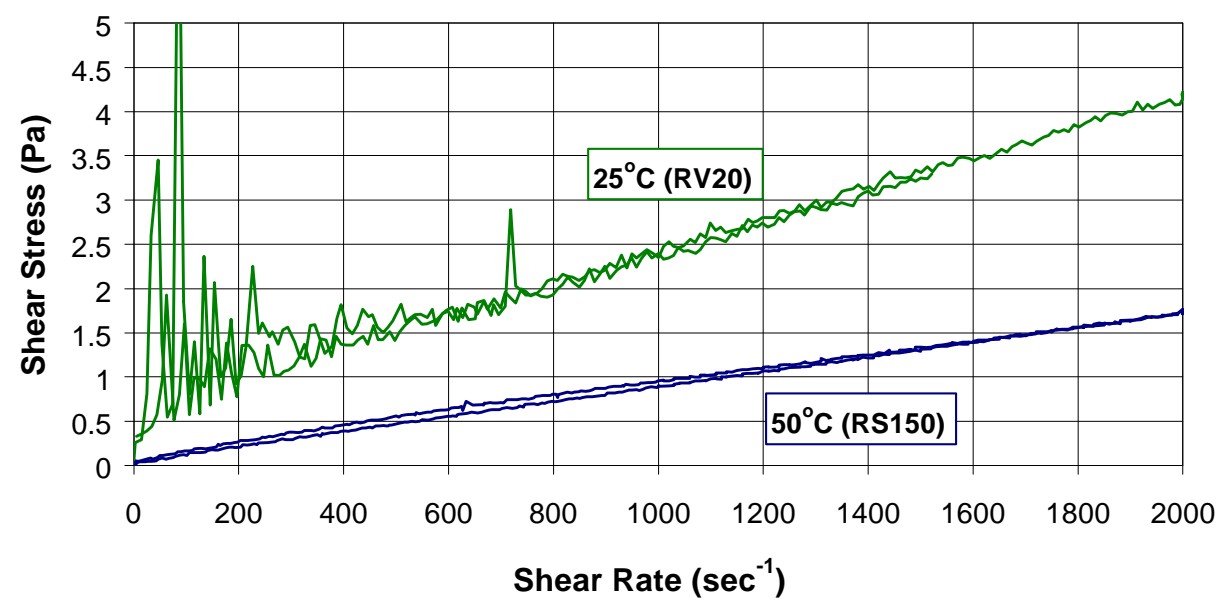

Figure 33. Rheology: leached and washed $\mathrm{HLW}$ at $20 \mathrm{wt} \%$ insoluble solids at $25^{\circ} \mathrm{C}$ and $50^{\circ} \mathrm{C}$

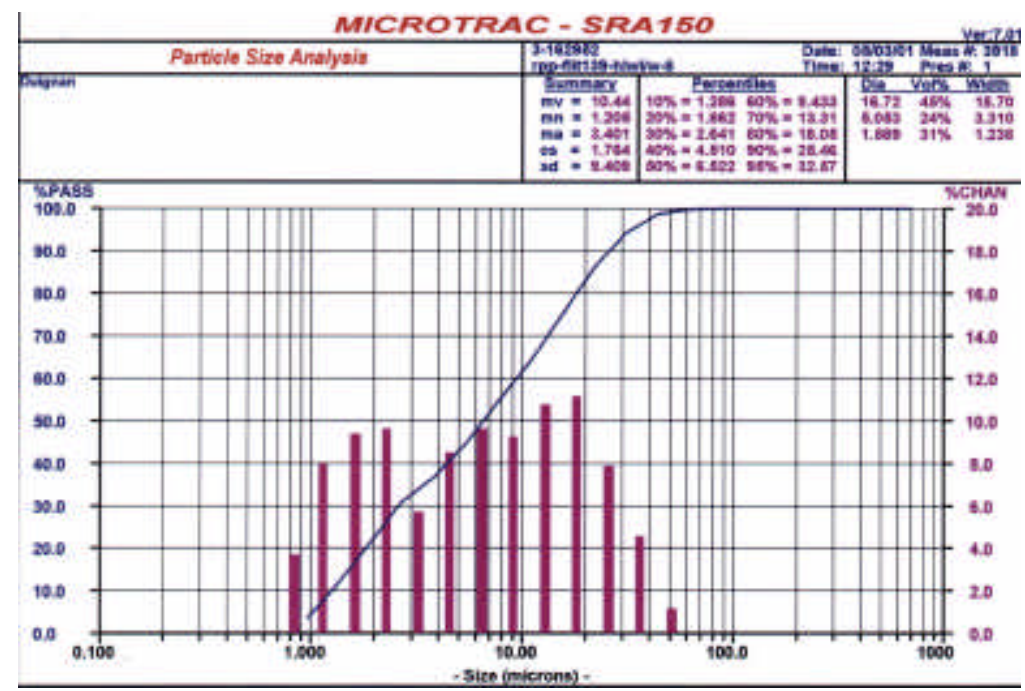

Figure 34a. Solids in the HLW leached simulant: AZ-101, entrained solids: Particle size Distribution by Volume 


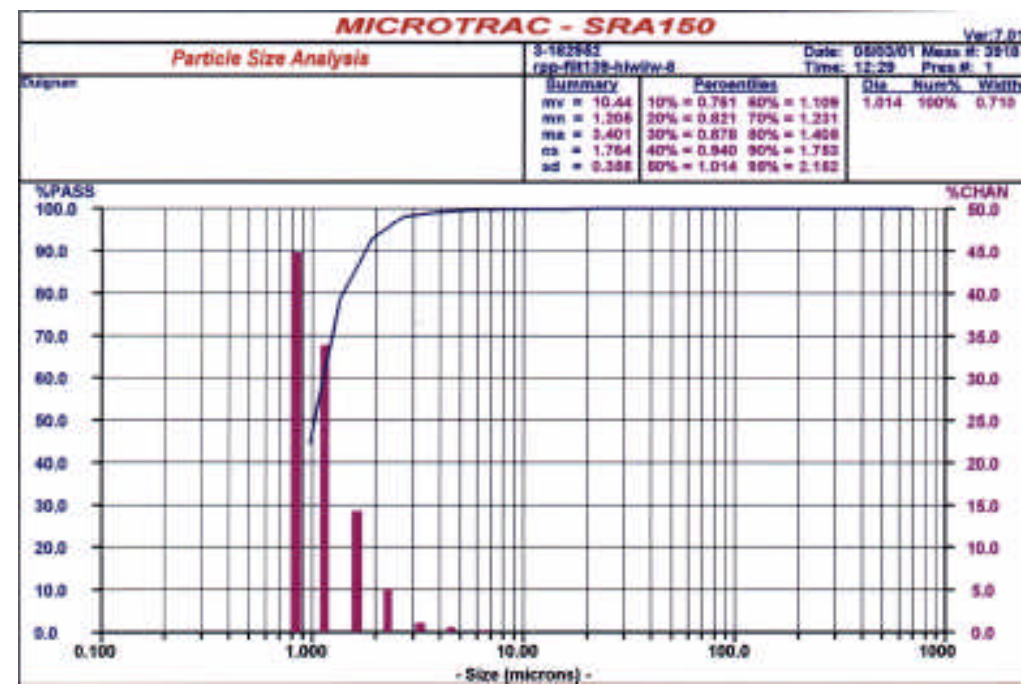

Figure 34b. Solids in the HLW leached simulant: AZ-101, entrained solids: Particle size Distribution by Number

The highlighted data in Figs. 32 and 33, along with all other measurements made on the slurry, are given in Table A7, Appendix A.

\subsection{Metal Compositions and Preparation}

The main goal of this study is to determine which slurry is the most abrasive so that a long term flow loop test can be done with that abrasive slurry to quantify the wear rate that will occur in the RPP-WTP pretreatment cross-flow filtration system. However, a slurry's abrasiveness can only be discussed with respect to the surface that is being abraded. To date, the selected in-cell pipe material will be made of 304L stainless steel (see RPP-WTP document SP-W375-M0001, Rev. A, 1/6/2000) and the cross-flow filter units will be made of 316L stainless steel. Both of these materials are similar in physical and chemical makeup. However, the slurry evaluation was done with both metals because there are some small differences. For instance, the 316L has more Molybdenum, which may make it a bit more resistant to certain types of corrosion, or that 304L is slightly harder when having similar heat treatments, which may make it more resistant to certain types of erosion. As listed in Table 1, for each slurry, a metal sample of each metal was provided to the subcontractor to test. Table 10 shows the Certified Material Test Report information for both metals. 
WSRC-TR-2002-00062, Rev. 0

SRT-RPP-2002-00022, Rev. 0

\begin{tabular}{|c|c|c|}
\hline \multicolumn{3}{|c|}{ 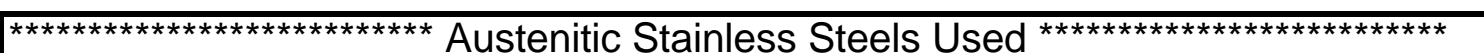 } \\
\hline $\begin{array}{l}\text { AISI Metal Type } \\
\text { per ASTM } \\
\text { Heat Number } \\
\text { Manufacturer Location } \\
\text { Heat Treatment } \\
\text { Grain Size } \\
0.2 \% \text { Yield Strength, psi } \\
\text { Tensile Strength, psi } \\
\text { Hardness, HB (Rockwell, Vickers) }\end{array}$ & $\begin{array}{c}304 \mathrm{~L} \\
\text { A276 } \\
6285 \\
\text { Germany } \\
1050^{\circ} \mathrm{C} \text { water quench } \\
9.5 \\
87710 \\
112260 \\
185(\mathrm{~B} 92,37)\end{array}$ & $\begin{array}{c}\text { 316L } \\
\text { A276 } \\
\text { P6463 } \\
\text { England } \\
1050^{\circ} \mathrm{C} \text { water quench } \\
7 \\
48922 \\
94203 \\
159(\mathrm{~B} 84,32)\end{array}$ \\
\hline 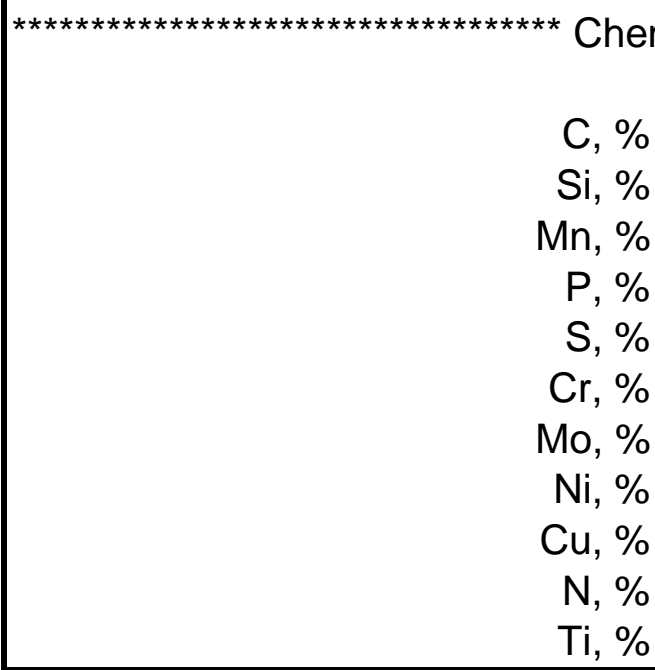 & \begin{tabular}{|c|} 
nical Analysis ********** \\
\\
0.020 \\
0.35 \\
1.88 \\
0.028 \\
0.009 \\
18.72 \\
0.03 \\
8.46 \\
0.09 \\
0.065 \\
NA
\end{tabular} & $\begin{array}{c} \\
0.018 \\
0.18 \\
1.98 \\
0.024 \\
0.005 \\
17.20 \\
2.15 \\
11.80 \\
0.20 \\
0.050 \\
<0.010\end{array}$ \\
\hline
\end{tabular}

Table 10. Composition of the metal samples used for slurry abrasivity evaluations

As per the ASTM standard, the metal specimens were made to the dimensions required by the testing equipment before they were sent to the WRES . Figure 35, show those dimensions and Fig. 3 show how the specimens were held in the test rig. 


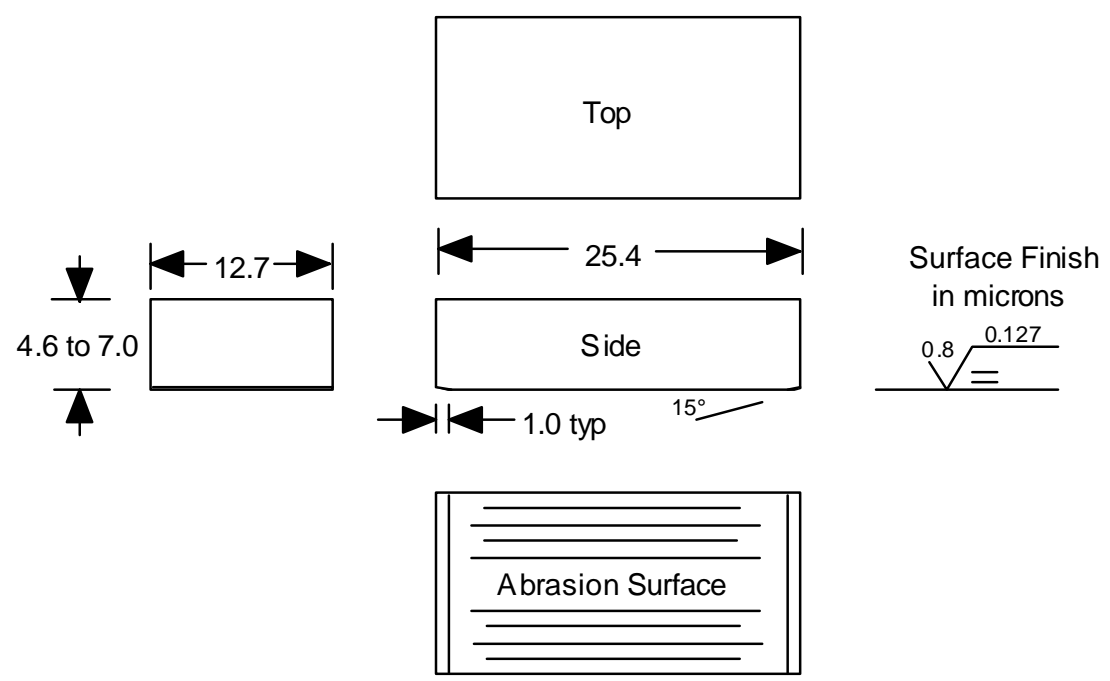

Figure 35. Typical metal specimen (the dimensions are in millimeters except where noted)

[Note: The surface texture symbol at the right indicates that the maximum surface roughness is to be 0.8 $\mu \mathrm{m}$, the maximum surface waviness is to be $0.127 \mu \mathrm{m}$, and that the predominant pattern of surface finish on the bottom of the metal specimen is to be parallel to the long axis, as illustrated.]

\subsection{Quality Assurance}

While the chosen method to measure the abrasivity of a slurry to a metal was done by a U.S national standard, adopted by the American Society For Testing \& Materials, the Quality Assurance program of the subcontractor that performed the test, was evaluated by WSRC. To insure quality, a source inspection visit was made by a qualified WSRC quality assurance inspector. The major conclusion made from that visit (Connelly, 2001) was that the vendor met the requirements of the ASTM standard and thus met the WSRC QA requirements to produce baseline data.

\subsection{Results}

\subsection{Overall Physical and Chemical Slurry Properties}

Figure 36 contains some important information to compare the seven slurries used in this slurry evaluation. These data are only highlights of the overall measurements taken for each slurry, which can be found in Tables A1 to A7 in Appendix A. The information here will be used to describe the wear test results in the next section, 4.2. 


\begin{tabular}{|c|c|c|c|c|c|c|c|}
\hline $\begin{array}{c}\text { Slurry Number ---> } \\
\text { Slurry Type ---> } \\
\text { V V - Type of Measurement - V V }\end{array}$ & $\begin{array}{c}1 \\
\text { HLW }\end{array}$ & $\begin{array}{c}2 \\
\text { HLW with } \\
\text { SBS recycle }\end{array}$ & $\begin{array}{c}3 \\
\mathrm{Sr} / \mathrm{TRU}\end{array}$ & $\begin{array}{c}4 \\
\text { Leached HLW }\end{array}$ & $\begin{array}{c}5 \\
\text { Leached HLW } \\
\text { with SBS recycle }\end{array}$ & $\begin{array}{c}6 \\
\text { Washed HLW }\end{array}$ & $\begin{array}{c}7 \\
\text { Leached \& } \\
\text { Washed HLW }\end{array}$ \\
\hline Normal Slurry Operating Temperature, ${ }^{\circ} \mathrm{C}$ & 25 & 25 & 25 & 85 & \begin{tabular}{|l|}
$25(1)$ \\
\end{tabular} & 25 & 85 \\
\hline Slurry Density, g/cc & 1.30 & 1.27 & 1.44 & 1.34 & 1.34 & 1.17 & 1.18 \\
\hline Supernatant Density, g/cc & 1.12 & 1.09 & 1.27 & 1.13 & 1.16 & 1.00 & 1.01 \\
\hline Slurry Consistency, cp @ 25ㄷ & 1.95 & 1.75 & 112.00 & 3.10 & 3.62 & 1.80 & 1.60 \\
\hline Slurry Yield Stress, $\mathrm{Pa} @ 25^{\circ} \mathrm{C}$ & 0.0 & 0.30 & 20.0 & 0.6 to 1.0 & 1.22 & 0.0 & 0.00 \\
\hline Supernatant Viscosity, cp @ 25ㅇ & 1.40 & 1.23 & NA & 1.40 & 2.21 & 1.10 & 1.00 \\
\hline Slurry Sodium Concentration, molarity & 1.94 & 2.00 & 6.47 & 2.78 & 3.60 & 0.09 & 0.20 \\
\hline Supernatant Sodium Concentration, molarity & 1.70 & 1.81 & 5.79 & 2.37 & 3.09 & 0.01 & 0.12 \\
\hline Slurry $\mathrm{pH}(2)$ & 13.2 & 12.8 & $9.6(3)$ & 11.7 & 13.4 & 7.5 & 11.0 \\
\hline Total Solids, wt\% & 30.9 & 26.8 & 45.7 & 32.3 & 33.2 & 19.2 & $18(4)$ \\
\hline Insoluble Solids, wt \% & 20.1 & 19.9 & 18.6 & 20.4 & 19.5 & 19.2 & $18(4)$ \\
\hline Solids Particle Size by Volume, micron (5) & $21.7(54 \%)$ & $16.7(45 \%)$ & $6.8(66 \%)$ & $19.2(45 \%)$ & $17.8(48 \%)$ & $11.7(72 \%)$ & $16.7(45 \%)$ \\
\hline Solids Particle Size by Number, micron & 1.0 & 1.0 & 1.1 & 1.0 & 1.0 & 1.0 & 1.0 \\
\hline
\end{tabular}

Figure 36. Physical properties of seven test simulants

Some additional slurry information to that given in Fig. 36 is:

- When this slurry evaluation task began at the end of 2000, the RPP flow sheet indicated that the filtration flow loop would filter leached slurries at the leaching temperature of $85^{\circ} \mathrm{C}$. Since then, the flow sheet has been changed such that the leached slurries will be cooled in the preparation tanks to $25^{\circ} \mathrm{C}$ before any filtering. As such, the last slurry to be tested was the washed and leached HLW with SBS recycle, number 5, and it was originally to be wear tested at $85^{\circ} \mathrm{C}$. With a change in the flow sheet the wear test vendor, WRES, was instructed to perform the test at the new filtering temperature, $25^{\circ} \mathrm{C}$.

- The main difference between all the HLW slurries and the LAW slurry is that the latter goes through a precipitation step and contains organic components and the former does not contain any organics.

- Rheologically, all of the HLW act as Newtonian mixtures, i.e, their shear stress versus shear rate relations are linear (or almost linear) and do not exhibit significant yield stresses. The LAW is a time dependent pseudoplastic mixture, also known as a thixotropic fluid.

- The insoluble solids in the HLW simulants settle fairly fast, in minutes, whereas the solids in the LAW slurry remain suspended for 30 minutes or more.

- As expected, the simulants which had a final step of washing, i.e., Nos. 6 and 7, displayed the lowest sodium content $(0.1 \mathrm{M}$ and $0.2 \mathrm{M}$, respectively) and the lowest density, $<1.2 \mathrm{~g} / \mathrm{mL}$. 
- The number of particles with an average size of 1 micron did not change with different process steps.

- Each simulant's $\mathrm{pH}$ changed slightly with time. The $\mathrm{pH}$ data shown in Fig. 36 were measured by WRES, and are also given in Appendix B. This $\mathrm{pH}$ is thought to be the most representative because it was measured just before each test. The exception was simulant No. 3, which was very thick and presented problems to measure, thus it was only measured at SRTC. Coincidentally, simulant No. 3 had a very low $\mathrm{pH}(\sim 10)$ because the caustic addition to the simulant was accidentally left out. Because there was a concern that the lower $\mathrm{pH}$ would make the slurry less abrasive, a separate corrosion test was done by SRTC (Mikalonis, 2001), as well as at the higher $\mathrm{pH}$, i.e., 14. No significant corrosion was found.

\subsection{Slurry Abrasion Response Number}

As stated in the beginning of this report, the primary reason to obtain a Slurry Abrasion Response (SAR) Number is to distinguish among all the slurry-metal combinations included in this study as to which will result in the most abrasion. Figure 37 shows the overall results for all the tests. This figure clearly shows the $5^{\text {th }}$ slurry, i.e., HLW with SBS recycle simulant that was washed and leached, was the most abrasive combination, with both $304 \mathrm{~L}$ and $306 \mathrm{~L}$ stainless steels. The complete vendor report is included as Appendix B.

On the first page of the report by White Rock Engineering Services, the quantitative SAR numbers are shown to be 206 with 304L stainless steel and 280 with $316 \mathrm{~L}$ stainless steel. SAR numbers over approximately 80 are considered abrasive and will cause wear to pipe and pump surfaces. The WRES goes further to state that SAR numbers above 200 can cause severe abrasion. However, this measure is only qualitative and can only be used in the context of slurries being more or less abrasive. In this context, slurry number 5 caused the most abrasion among the 7 tested and, therefore, should be used in the planned wear test to give a conservative estimate of wear rates.

Slurry number 2 came in as the second most abrasive, with SAR numbers of 163 for 304L and 221 for 316L. This is important because both slurry 5 and 2 were the only ones that contained the addition of SBS recycle. This was unexpected because the Submerged Bed Scrubber recycle was basically water; it added very little in the way of solids. That is, it had $0.28 \mathrm{wt} \%$ in total solids and $0.03 \mathrm{wt} \%$ insoluble solids. The recycle stream is condensate, which comes from the glass melter exhaust system after it goes through the SBS system. The solids are some glass fines and glassformers that are carried out of a melter through the off-gas system by the venting vapors.

The as-received SBS recycle was slightly acidic, i.e., $\mathrm{pH}=3$. Before mixing it with the HLW simulant, its $\mathrm{pH}$ was adjusted to a $\mathrm{pH}=12$ by adding a very small amount of $5 \mathrm{M} \mathrm{NaOH}$. As 
mentioned in the Discussion sections, 3.3.2.2 and 3.3.2.5, the SBS recycle was added to the HLW simulant with a mass ratio of 1 part SBS recycle to 8.58 parts HLW, which had a insoluble solids content of $2.7 \mathrm{wt} \%$. The resulting mixture was decanted to obtain a final insoluble solids concentration of $20 \mathrm{wt} \%$.

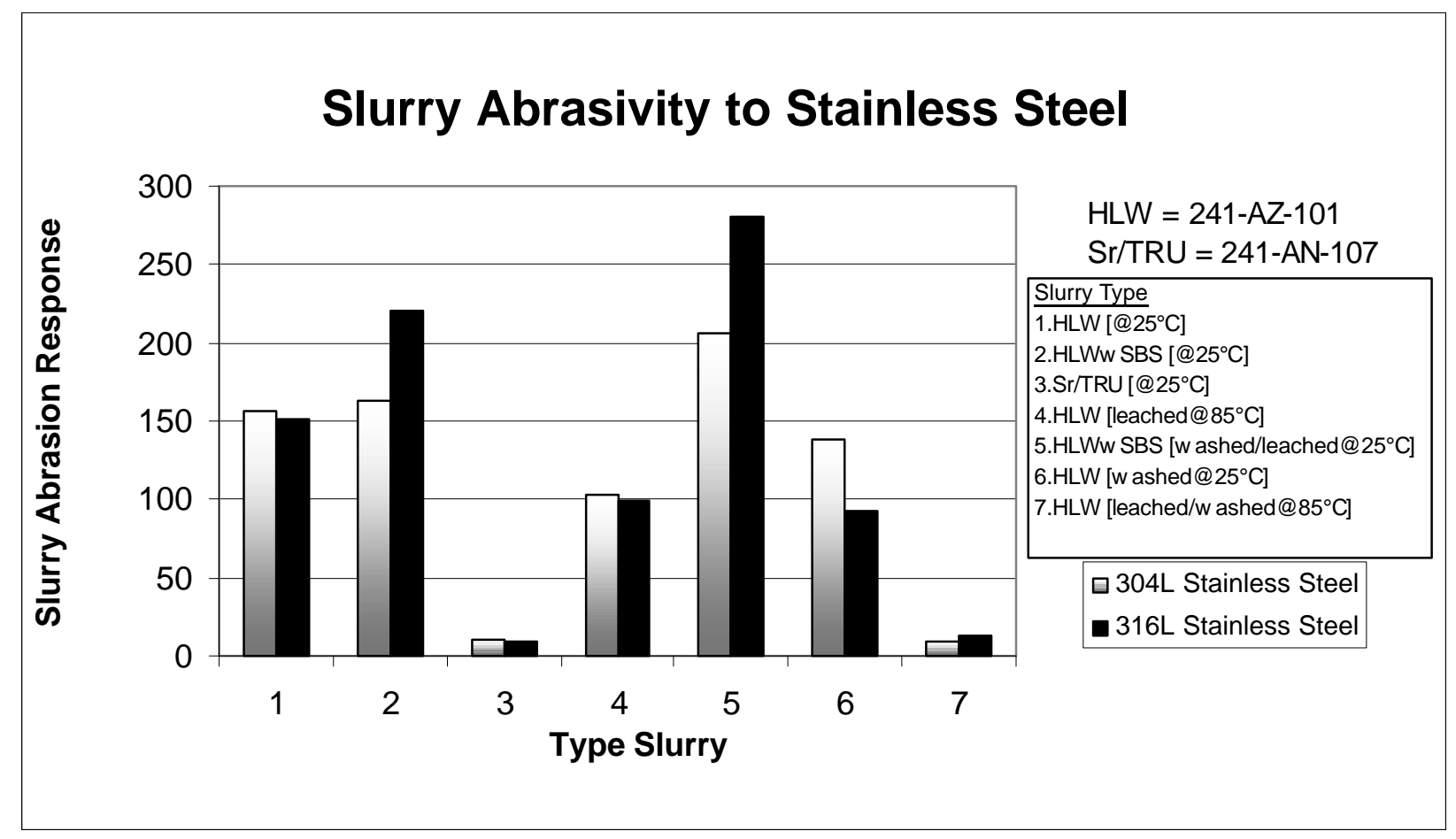

Figure 37. SAR Number for all 7 slurries with both 304L and 316L stainless steels

When comparing the HLW simulant with no SBS recycle, slurry number 1 in Fig. 37, to the HLW with SBS recycle, slurry number 2, there is a significant effect, especially with the high abrasion to $316 \mathrm{~L}$ stainless steel. The $304 \mathrm{~L}$ stainless steel was thought to be slightly more susceptible to corrosion than the $316 \mathrm{~L}$, and generally that was true, except for slurries with SBS recycle. The non-intuitive effect became more pronounced for slurry number 5 , which differs from number 2 in that it had been washed with $0.01 \mathrm{M} \mathrm{NaOH}$ and then leached with $3 \mathrm{M} \mathrm{NaOH}$. That is, the base liquid of slurry number 5 was $3 \mathrm{M} \mathrm{NaOH}$ whereas for slurry number 2 it was 1 $\mathrm{M} \mathrm{NaOH}$ and $1 \mathrm{M} \mathrm{NaNO3.} \mathrm{Another} \mathrm{contribution} \mathrm{could} \mathrm{have} \mathrm{been} \mathrm{from} \mathrm{the} \mathrm{small} \mathrm{difference} \mathrm{in}$ surface hardness. Table 10 shows that the $316 \mathrm{~L}$ stainless steel was slightly softer (HB159) than the 304L stainless steel (HB185), making the 316 a little more susceptible to ductile erosion, which is the predominant form of erosion in a SAR test (Duignan and Lee, 2001). That is, a SAR test produces wear by rubbing a piece of metal on a lap surface that is saturated with a 
slurry, as opposed to perpendicularly bombarding a surface with a slurry stream. Whatever is the cause for the higher abrasivity, the addition of SBS recycle cannot be ignored.

The WRES report in Appendix B also includes slurry solids microphotographs for each slurry and the metal specimens that were abraded during the tests. Unfortunately, those photographs do not help to distinguish among the slurries, which were the most abrasive, i.e., numbers 1, 2, 4, 5, and 6. However, there is a distinct difference in abrasivity between those five slurries and numbers 3 and 7. This may indicate that the corrosive element of wear cannot be neglected, and in fact, it is probably the synergistic effect of erosion and corrosion that is producing the most wear.

One final note, the most abrasive slurry-metal combination, number 5 with $316 \mathrm{~L}$, had to be repeated because in the first test WRES found the slurry in one of the bottles to be clumping. The original test (see test no. S-1033 in Appendix B) gave two very divergent SAR numbers, (approximately 280 and 380). It is not known why the second trial in that test gave a much higher number, but the test was repeated with spare slurry (S-1033R), which was supplied for just such an event. The new test results agreed well with the first trial of the initial test, giving an average SAR number of 280 , therefore this results was taken as accurate.

\subsection{Conclusion}

Seven RPP-WTP cross-flow ultrafiltration slurry simulants were tested for abrasivity to two different types of stainless steel, 304L and 316L. The slurry, which showed the highest abrasivity, would be selected for use in a scaled flow loop to estimate wear rates in the full-scale filtration system. The abrasivity test is called a Slurry Abrasion Response Number test, which is a nationally accepted standard, ASTM G75-2001. This test cannot give an absolute value of the wear rates in any specific flow system but can indicate if an abrasive environment exists. Further, by comparing SAR numbers of different slurries under similar conditions, it is possible to select a slurry which will present the most abrasion.

- In general, both metals exhibited similar abrasion responses to each slurry simulant, however, there were some difference when SBS recycle was added to the HLW simulants, the 316L seemed to abrade slightly faster.

- Among the seven slurries, number 5, the HLW simulant with SBS recycle that was washed 3 times at $25^{\circ} \mathrm{C} \pm 5^{\circ} \mathrm{C}$ and then leached at $85^{\circ} \mathrm{C} \pm 5^{\circ} \mathrm{C}$, showed the highest SAR numbers: 206 for $304 \mathrm{~L}$ and 280 for $316 \mathrm{~L}$. According to the wear test vendor, SAR numbers above 200 exhibit severe abrasion environments. However, the measure is qualitative and such slurries must be tested in more prototypic situations to better quantify actual wear rates. 


\subsection{Recommendations}

- Use slurry number 5 in a scaled test to determine the cross-flow ultrafiltration system wear rates.

- Use both 304L and 316L in the scaled test. The current plan for the actual RPP-WTP in-cell pipe will be made of both 304L and 316L (e.g., the cross-flow filter and its housing are to be of 316L). Since the level of abrasivity was found to be severe for both 304L and 316L the test should include both stainless steels. The 316L stainless steel seems to be more susceptible to wear in the presence of SBS recycle, but the complicated flow mechanisms in the filtering system may also cause considerable wear in 304L.

\subsection{References}

Bechtel, 2000. Design, Construction, and Commissioning of the Hanford Tank Waste Treatment and Immobilization Plant. Contract No. DE-AC27-01RV14136 signed between Bechtel National, Inc. (Ron Naventi, Senior Vice President) and the Department of Energy (Harry L. Boston, Acting Manager of the Office of River Protection).

Clark, H.McI., Tuzson, J., and Wong, K.K., 2000. Measurements of specific energies for erosive wear using a Coriolis erosion tester. Wear 241, 1-9.

Coleman, C.J., 2001. Recipes for RPP AZ-101-102 erosion simulants. Westinghouse Savannah River Company Inter-office Memorandum No. SRT-AD01-0222 to Mark Duignan (May 25).

Connelly, J.J., 2001. Source Inspection Surveillance of Slurry Abrasivity (Miller Number) and Slurry Abrasion Response of Materials (SAR Number) Testing at White Rock Engineering Services. Westinghouse Savannah River Document No. 2001-SUR-11-0009 (November).

Danielson, M. and Pitman, S., 1999. Results of the non-radioactive corrosion test for BNFL. Attachment of Battelle Pacific Northwest National Laboratory Transmittal Letter No. 005220 from E. Morrey to M. Johnson dated July 28, 1999.

Duignan, M.R., 2001a. Computational assistance for the slurry wear evaluation of the pretreatment cross-flow filtration and evaporation systems. Westinghouse Savannah River Company Doc. No. WSRC-TR-2001-000194 (also SRT-RPP-2001-00041). (June 11)

Duignan, M.R., 2001b. RPP-WTP submittal report of interim report: Selection of slurry simulant for the slurry wear evaluation of the RPP-WTP pretreatment cross-flow filtration system. Memorandum transmitted from H.R. Sturm, Jr. to R.A. Peterson. Document No. SRT-RPP2001-00230 (December 13) 
WSRC-TR-2002-00062, Rev. 0

SRT-RPP-2002-00022, Rev. 0

Duignan, M.R., 2001c. Nonconformance Report: Hanford Tank 241-AN-107 Slurry Simulant+Precipitants+Entrained Solids. Westinghouse Savannah River Company Document No. 2001-NCR-11-2001 (January 30) - also listed under NCR closure letter SRT-QAE-200100076 from K.F. Thompson to J.J. Connelly dated June 7, 2001

Duignan, M.R. and Lee, S.Y., 2001. River Protection Project - Waste Treatment Plant Slurry Wear Evaluation: Literature Review. Westinghouse Savannah River Company Document No. WSRC-TR-2001-00156. [also under No. SRT-RPP-2001-00033] (March 21).

Eibling, R.E. and Nash, C.A., 2001. Hanford waste simulants created to support the research and development on the River Protection Project - Waste Treatment Plant. Westinghouse Savannah River Company Report No. WSRC-TR-2000-00338. [also under No. SRT-RPP2000-00338] (February).

Elmore, M.R., 2000. Simulant erosion testing. Battelle Pacific Northwest National Laboratory Report No. WTP-RPT-001, October.

Golcar, G.R., Brooks, K.P., Darab, J.G., Davis, J.M., Jagoda, L.K., 2000. Development of inactive high level waste envelope D simulant for scaled crossflow filtration testing. Battelle Pacific Northwest National Laboratory Report No. PNWD-3042 (also BNFL-RPT-033, Rev. 0), (August 2000).

Hansen, E. K., 2001a. Rheological properties of 20 wt\% i.s. Sr/TRU AN-107 precipitate. Westinghouse Savannah River Interoffice Memorandum No. SRT-PDH-2001-004 (January 19).

Hansen, E. K., 2001b. Physical and rheological results of 20 wt.\% i.s. AZ-101 Modified NCAW Simulant. Westinghouse Savannah River Interoffice Memorandum No. SRT-RPP-2001-00048 (April 7).

Hansen, E. K., 2002. Rheological and physical measurements of Gita AZ-101 Simulant blended with SBS. Westinghouse Savannah River Interoffice Memorandum No. SRT-RPP-2002-00039 (February).

Hodgson, K.M., 1995. Tank characterization report for double-shell tank 241-AZ-101. Westinghouse Hanford Company Report No. WHC-SD-WM-ER-410 (July 26).

Johnson, M.E., Calloway Jr. T.B., and Reynolds, D.A., 2000. River Protection Project - Waste Treatment Plant Filtration and Evaporation: Erosion Testing Test Specification. Document No. TSP-W375-00-00005, Rev. 0 (November 28, 2000).

Lumetta, L.J. and Hoopes, F.V., 1999. Washing of the AN-107 entrained solids.", River Protection Project - Waste Treatment Plant Report No. BNFL-RPT-007, Rev. 0, (June 1999). 
McGrail, B.P., 1991. Results of the analysis of the large chunk of material and the measurement of the Miller number for DST-101-AZ Core \#3 Waste. Battelle Pacific Northwest National Laboratory Transmittal Letter No. 9101055 from B.P. McGrail to L.M. Sasaki on February 11, 1991.

McTaggart, K., 2000. System Description for HLW Pre-Treatment - System PT-220. River Protection Project - Waste Treatment Plant Document No. SD-W375PT-PR00012, Rev. 2. (February 16, 2000).

Mickalonis, J.I., 2001. Pitting potential of 304L and 316L stainless steel in a Sr/TRU supernate. Westinghouse Savannah River Company Inter-office Memorandum No. SRT-MTS-200120007, to M. R. Duignan on March 22, 2001.

Miller, J.D. and Miller, J.E., 1993. The Miller Number - a review. Proceedings of the $12^{\text {th }}$ handling and pipeline transport, Hydrotransport 12, BHR Fluid Engineering, held at Brugge, Belgium, 175-189. (September 28-30)

Rapko, B.M. and Wagner, M.J., 1997. Caustic leaching of composite AZ-101/102 Hanford Tank Sludge, Pacific Northwest National Laboratory Document No. PNNL-11580.

Smith H.D. and Elmore, M.R., 1992. Corrosion studies of carbon steel under impinging jets of simulated slurries of neutralized current acid waste (NCAW) and neutralized cladding removal waste (NCRW). Battelle Pacific Northwest National Laboratory Report No. PNL-7816 (also UC-721), (January).

Stiver, B., 2000. System Description for LAW Ultrafiltration - System PT-230. River Protection Project - Waste Treatment Plant Document No. SD-W375PT-PR00013, Rev. 2. (February 17, 2000).

Swanson, L. 2000. RPP-WTP Process Flowsheet Overview. River Protection Project - Waste Treatment Plant Document No. RPT-W375-TE00016, Rev. 0A.(Draft) (February 18, 2000).

Wilkinson, B. D., 2001a. Physical and rheological results for RPP-FILT139-HLW simulants. Westinghouse Savannah River Company Interoffice Memorandum No. SRT-RPP-2001000106, Rev. 1 (July 9).

Wilkinson, B. D., 2001b. Rheological results for RPP-FILT139-HLW simulants. Westinghouse Savannah River Company Interoffice Memorandum No. SRT-RPP-2001-000112 (July 16).

Xie, Y., Clark, H.McI., and Hawthorne, H.M. 1999. Modelling slurry particle dynamics in the Coriolis erosion tester. Wear 225-229, 405-416. 


\section{APPENDIX A}

\section{Data Sheets for Each Simulant}

The following seven tables list all physical and chemical properties measured on each of the seven simulants tested. Before the simulated slurries were sent to White Rock Engineering Services, to obtain the Slurry Abrasivity Numbers, samples were taken from each to completely determine the slurry characteristics. The results of the measurements are shown in the tables.

The tables are self explanatory, however, for convenience some major features are explained here:

To save space in the table the RPP sample number was reduced to Prefix + number. For example a sample number may be RPP-FILT139-HLWleached+1, which is the first $(+1)$ sample taken of leached HLW simulant, therefore the first sample in the $2^{\text {nd }}$ row shows the sample number to be Prefix +1 . The second sample number is Prefix +2 , and so on.

The code numbers in the $6^{\text {th }}$ row indicates what measurements were made or what process was done, i.e., type of dissolution. The number codes are given at the bottom of each table and are repeated here for convenience:

1 = Dissolution - sodium peroxide / uptake with water

2 = Dissolution - sodium peroxide / uptake with hydrochloric acid

$3=$ Dissolution with aquaregent $-25 \%$ nitric and $75 \%$ hydrocloric acid

$4=$ Chloride by ion selective emission

5 = Floride by ion selective emission

$6=\mathrm{ICP}-\mathrm{ES}$

7 = Potasium by Atomic Absorbtion
8 = Total inorganic/ organic carbon

$9=\mathrm{IC}-$ anions

$10=$ Total solids

$11=$ Suspended solids

12 = Microtrac - particle size distribution

$13=$ Specific gravity

$14=\mathrm{pH}$

Columns 5, 6, and 7 contain analytical data for the simulant from three different dissolution methods. There can be data for the same element in all three columns, e.g., Sr. The entry that has a bold border and shaded box is the preferred measurement value. The last column only shows the corrosivity level of the simulant as required by the U.S. Department of Transportation to send it to the wear test vendor. The second to last column only shows the average values of the particle sizes. See the appropriate section in the body of the report of the entire distribution. 
WSRC-TR-2002-00062, Rev. 0

SRT-RPP-2002-00022, Rev. 0

Table A1. RPP-WTP Hanford Waste Simulant: HLW (AZ-101)

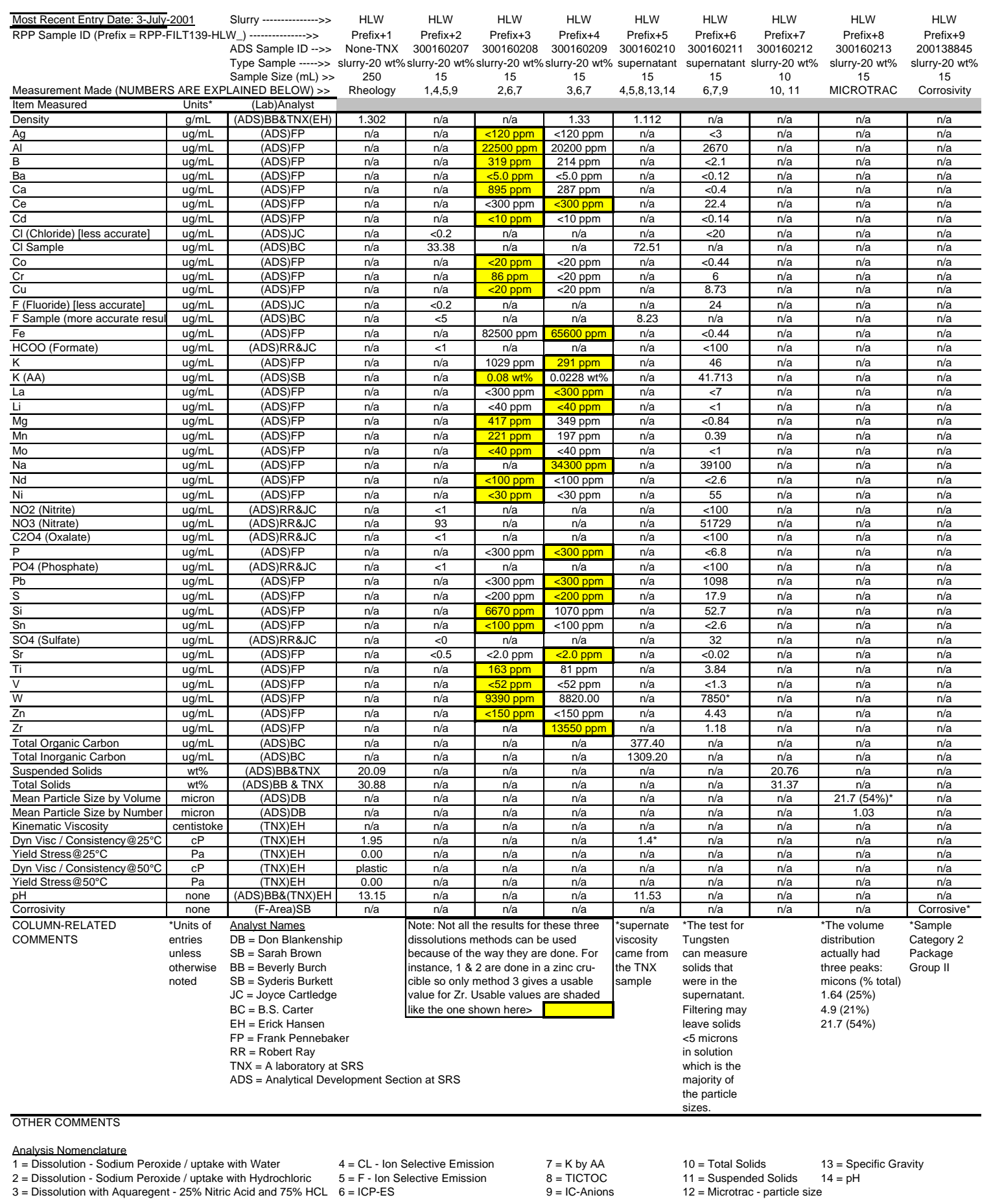


WSRC-TR-2002-00062, Rev. 0

SRT-RPP-2002-00022, Rev. 0

\section{Table A2. RPP-WTP Hanford Waste Simulant: HLW (AZ-101) with SRS Recycle}

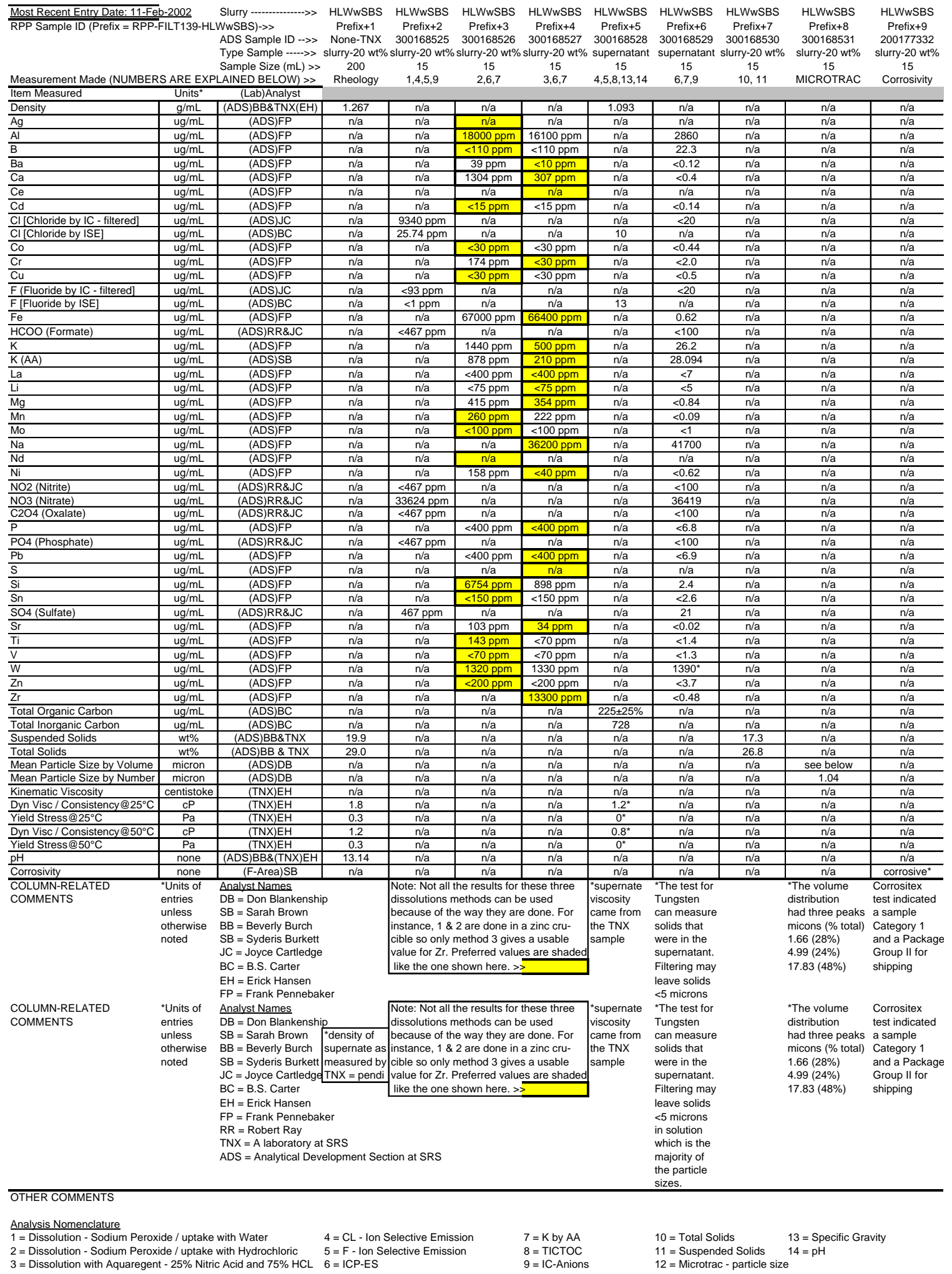


Table A3. RPP-WTP Hanford Waste Simulant: LAW (AN-107) with Sr/TRU Precipitant

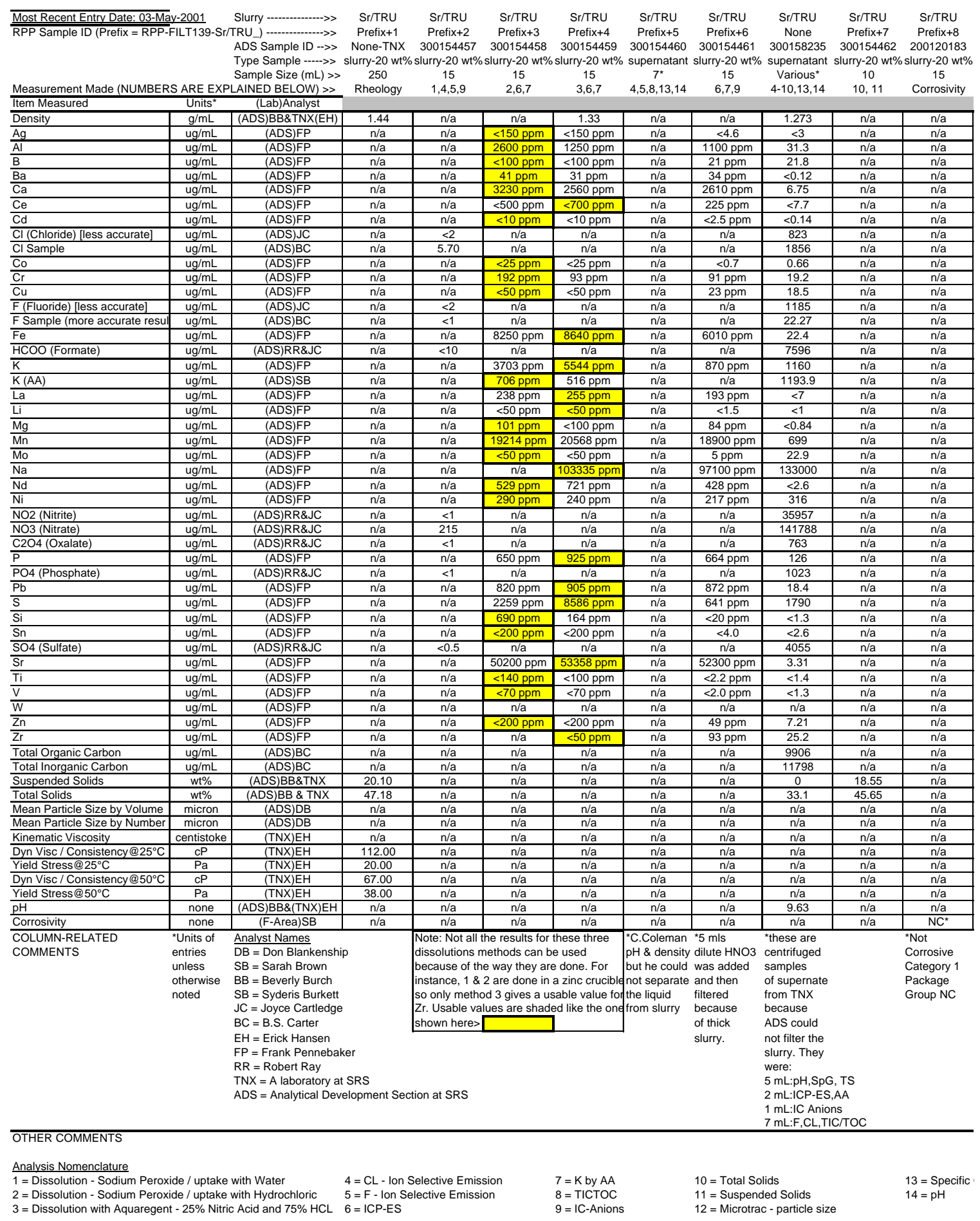


WSRC-TR-2002-00062, Rev. 0

SRT-RPP-2002-00022, Rev. 0

Table A4. RPP-WTP Hanford Waste Simulant: Leached HLW (AZ-101)

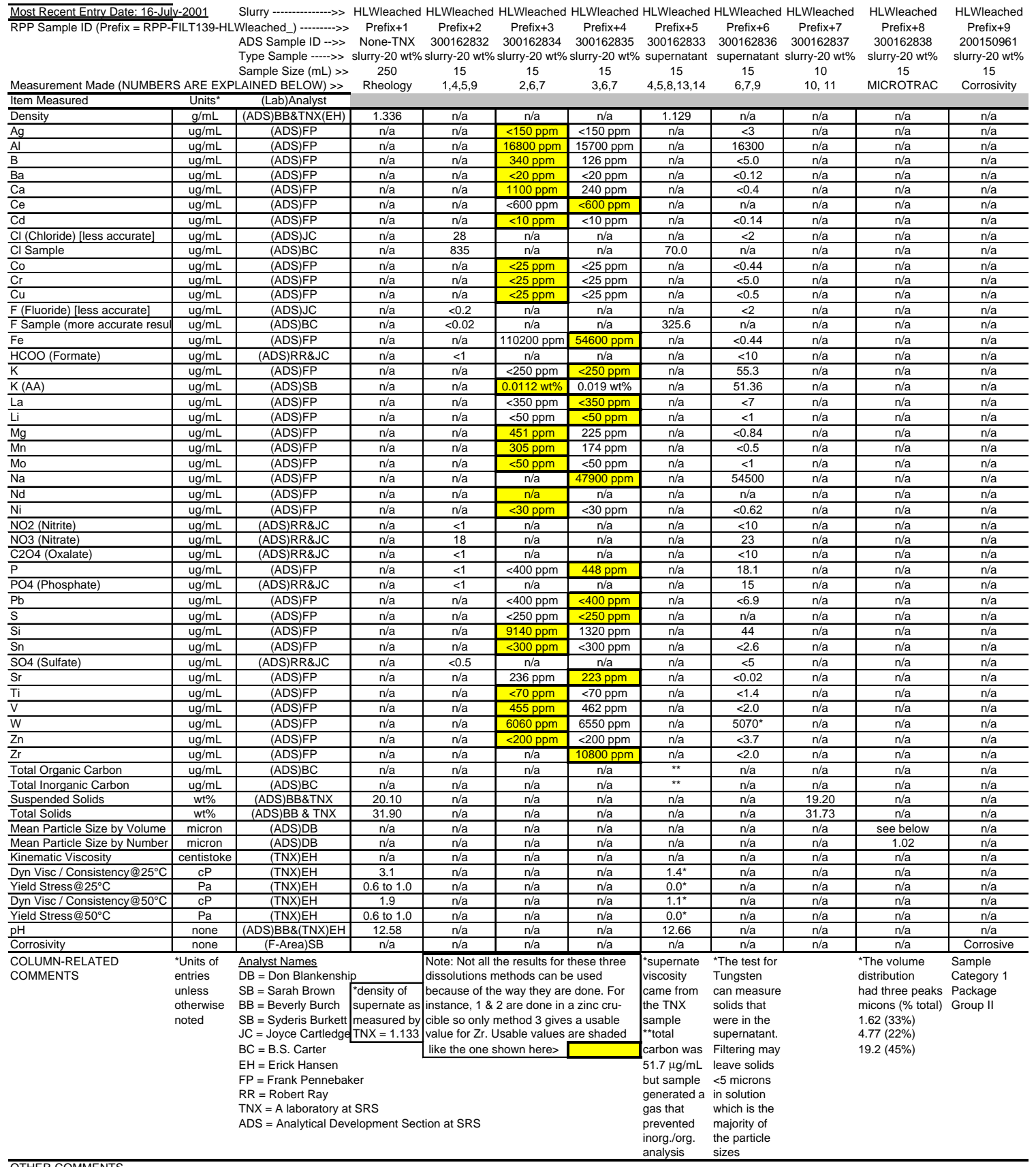

Analysis Nomenclature

$\quad 4=\mathrm{CL}-$ Ion Selective Emission F $=\mathrm{F}$ - Ion Selective Emission

$3=$ Dissolution with Aquaregent $-25 \%$ Nitric Acid and $75 \% \mathrm{HCL} \quad 6=\mathrm{ICP}-\mathrm{ES}$ $\begin{array}{lll}7=\text { K by AA } & 10=\text { Total Solids } & 13=\text { Specific Gravity } \\ 8=\text { TICTOC } & 11=\text { Suspended Solids } & 14=\mathrm{pH} \\ 9=\text { IC-Anions } & 12=\text { Microtrac } \text { - particle size }\end{array}$ 


\section{Table A5. RPP-WTP Hanford Waste Simulant: Leached HLW (AZ-101) with SRS Recycle}

\begin{tabular}{|c|c|c|c|c|c|c|c|c|c|c|c|}
\hline \multirow{2}{*}{\multicolumn{3}{|c|}{$\begin{array}{l}\text { Most Recent Entry Date: } 11-\text { Feb-2002 } \\
\text { RPP Sample ID (Prefix = RPP-FILT139-HLWwSBSw\&I)->> }\end{array}$}} & \multicolumn{9}{|c|}{ 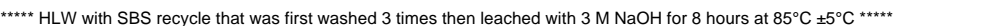 } \\
\hline & & & Prefix+1 & Prefix +2 & Prefix+3 & Prefix +4 & Prefix +5 & Prefix +6 & Prefix+7 & Prefix +8 & Prefix+9 \\
\hline \multirow{3}{*}{\multicolumn{3}{|c|}{$\begin{aligned}\text { RPP Sample ID (Prefix = RPP-FILT139-HLWwSBSW\&I) })->> \\
\text { ADS Sample ID -->> } \\
\text { Type Sample --->>> } \\
\text { Sample Size }(\mathrm{mL})>> \\
\text { Measurement Made (NUMBERS ARE EXPLAINED BELOW) >> }\end{aligned}$}} & $\begin{array}{l}\text { None-TNX } \\
\text { slurry20wt } \%\end{array}$ & $\begin{array}{l}300170801 \\
\text { slurry20wt\% }\end{array}$ & $\begin{array}{l}300170802 \\
\text { slurry20wt } \%\end{array}$ & $\begin{array}{l}300170803 \\
\text { slurry20wt\% }\end{array}$ & $\begin{array}{l}300170804 \\
\text { supernatant }\end{array}$ & $\begin{array}{l}300170805 \\
\text { supernatant }\end{array}$ & $\begin{array}{l}300170806 \\
\text { slurry20 wt\% }\end{array}$ & $\begin{array}{l}300170807 \\
\text { slurry20 wt } \%\end{array}$ & $\begin{array}{l}200184417 \\
\text { slurry20 wt\% }\end{array}$ \\
\hline & & & 200 & 15 & 15 & 15 & 15 & 15 & 15 & 15 & 15 \\
\hline & & & Rheology & $1,4,5,9$ & $2,6,7$ & $3,6,7$ & $4,5,8,13,14$ & $6,7,9$ & 10,11 & MICROTRAC & Corrosivity \\
\hline \multicolumn{12}{|c|}{$\begin{array}{lll}\text { Item Measured } & \text { Units }^{*} & \text { (Lab)Analyst } \\
\end{array}$} \\
\hline Density & $\mathrm{g} / \mathrm{mL}$ & (ADS)BB\&TNX(EH) & 1.343 & $n / a$ & $\mathrm{n} / \mathrm{a}$ & $\mathrm{n} / \mathrm{a}$ & 1.162 & $\mathrm{n} / \mathrm{a}$ & $n / a$ & $\mathrm{n} / \mathrm{a}$ & $\mathrm{n} / \mathrm{a}$ \\
\hline $\mathrm{Ag}$ & $\mathrm{ug} / \mathrm{mL}$ & (ADS)FP & $\mathrm{n} / \mathrm{a}$ & $\mathrm{n} / \mathrm{a}$ & $\mathrm{n} / \mathrm{a}$ & $\mathrm{n} / \mathrm{a}$ & $\mathrm{n} / \mathrm{a}$ & $\mathrm{n} / \mathrm{a}$ & $n / a$ & $\mathrm{n} / \mathrm{a}$ & $n / a$ \\
\hline$\overline{\mathrm{Al}}$ & $\mathrm{ug} / \mathrm{mL}$ & (ADS)FP & $n / a$ & $n / a$ & $16500 \mathrm{ppm}$ & $15600 \mathrm{ppm}$ & $\mathrm{n} / \mathrm{a}$ & 17818 & $\mathrm{n} / \mathrm{a}$ & $\mathrm{n} / \mathrm{a}$ & $n / a$ \\
\hline $\mathrm{B}$ & $\mathrm{ug} / \mathrm{mL}$ & (ADS)FP & $n / a$ & $n / a$ & $132 \mathrm{ppm}$ & $112 \mathrm{ppm}$ & $n / a$ & $<2.1$ & $n / a$ & $n / a$ & $n / a$ \\
\hline $\mathrm{Ba}$ & $\mathrm{ug} / \mathrm{mL}$ & (ADS)FP & $n / a$ & $n / a$ & $<30 \mathrm{ppm}$ & $<30 \mathrm{ppm}$ & $\mathrm{n} / \mathrm{a}$ & 6.58 & $n / a$ & $n / a$ & $n / a$ \\
\hline $\mathrm{Ca}$ & $\mathrm{ug} / \mathrm{mL}$ & (ADS)FP & $\mathrm{n} / \mathrm{a}$ & $n / a$ & $967 \mathrm{ppm}$ & $370 \mathrm{ppm}$ & $\mathrm{n} / \mathrm{a}$ & 0.76 & $n / a$ & $\mathrm{n} / \mathrm{a}$ & $n / a$ \\
\hline $\mathrm{Ce}$ & $\mathrm{ug} / \mathrm{mL}$ & (ADS)FP & $\mathrm{n} / \mathrm{a}$ & $n / a$ & $\mathrm{n} / \mathrm{a}$ & $\mathrm{n} / \mathrm{a}$ & $n / a$ & $\mathrm{n} / \mathrm{a}$ & $n / a$ & $n / a$ & $n / a$ \\
\hline $\mathrm{Cd}$ & $\mathrm{ug} / \mathrm{mL}$ & (ADS)FP & $\mathrm{n} / \mathrm{a}$ & $\mathrm{n} / \mathrm{a}$ & $<20 \mathrm{ppm}$ & $<20 \mathrm{ppm}$ & $\mathrm{n} / \mathrm{a}$ & $<0.14$ & $n / a$ & $\mathrm{n} / \mathrm{a}$ & $n / a$ \\
\hline $\mathrm{CI}$ [Chloride by IC - filtered] & $\mathrm{ug} / \mathrm{mL}$ & $(\mathrm{ADS}) \mathrm{JC}$ & $\mathrm{n} / \mathrm{a}$ & $3204 \mathrm{ppm}$ & $\mathrm{n} / \mathrm{a}$ & $\mathrm{n} / \mathrm{a}$ & $<18^{* \star}$ & $<47$ & $\mathrm{n} / \mathrm{a}$ & $\mathrm{n} / \mathrm{a}$ & $\mathrm{n} / \mathrm{a}$ \\
\hline $\mathrm{Cl}$ [Chloride by ISE] & $\mathrm{ug} / \mathrm{mL}$ & (ADS)BC & $\mathrm{n} / \mathrm{a}$ & $\mathrm{n} / \mathrm{a}$ & $\mathrm{n} / \mathrm{a}$ & $\mathrm{n} / \mathrm{a}$ & not done ${ }^{\star \star}$ & $\mathrm{n} / \mathrm{a}$ & $\mathrm{n} / \mathrm{a}$ & $\mathrm{n} / \mathrm{a}$ & $n / a$ \\
\hline Co & $\mathrm{ug} / \mathrm{mL}$ & (ADS)FP & $\mathrm{n} / \mathrm{a}$ & $\mathrm{n} / \mathrm{a}$ & $<30 \mathrm{ppm}$ & $<30 \mathrm{ppm}$ & $\mathrm{n} / \mathrm{a}$ & $<0.44$ & $n / a$ & $\mathrm{n} / \mathrm{a}$ & $n / a$ \\
\hline $\mathrm{Cr}$ & $\mathrm{ug} / \mathrm{mL}$ & (ADS)FP & $\mathrm{n} / \mathrm{a}$ & $n / a$ & $45 \mathrm{ppm}$ & $<30 \mathrm{ppm}$ & $n / a$ & 1.12 & $n / a$ & $n / a$ & $n / a$ \\
\hline $\mathrm{Cu}$ & $\mathrm{ug} / \mathrm{mL}$ & (ADS)FP & $\mathrm{n} / \mathrm{a}$ & $\mathrm{n} / \mathrm{a}$ & $<30 \mathrm{ppm}$ & $<30 \mathrm{ppm}$ & $\mathrm{n} / \mathrm{a}$ & $<0.5$ & $\mathrm{n} / \mathrm{a}$ & $\mathrm{n} / \mathrm{a}$ & $n / a$ \\
\hline F[Fluoride by IC - filtered] & $\mathrm{ug} / \mathrm{mL}$ & (ADS)JC & $n / a$ & $<95 \mathrm{ppm}$ & $\mathrm{n} / \mathrm{a}$ & $\mathrm{n} / \mathrm{a}$ & $<18^{* \star}$ & $<47$ & $n / a$ & $\mathrm{n} / \mathrm{a}$ & $n / a$ \\
\hline F [Fluoride by ISE] & $\mathrm{ug} / \mathrm{mL}$ & (ADS)BC & $\mathrm{n} / \mathrm{a}$ & $\mathrm{n} / \mathrm{a}$ & $\mathrm{n} / \mathrm{a}$ & $\mathrm{n} / \mathrm{a}$ & not done $\mathrm{e}^{\star \star}$ & $\mathrm{n} / \mathrm{a}$ & $n / a$ & $\mathrm{n} / \mathrm{a}$ & $\mathrm{n} / \mathrm{a}$ \\
\hline $\mathrm{Fe}$ & $\mathrm{ug} / \mathrm{mL}$ & (ADS)FP & $\mathrm{n} / \mathrm{a}$ & $\mathrm{n} / \mathrm{a}$ & $76000 \mathrm{ppm}$ & $86900 \mathrm{ppm}$ & $\mathrm{n} / \mathrm{a}$ & $<0.44$ & $n / a$ & $\mathrm{n} / \mathrm{a}$ & $n / a$ \\
\hline HCOO (Formate) & $\mathrm{ug} / \mathrm{mL}$ & (ADS)RR\&JC & $\mathrm{n} / \mathrm{a}$ & $<473 \mathrm{ppm}$ & $\mathrm{n} / \mathrm{a}$ & $\mathrm{n} / \mathrm{a}$ & $<89^{* *}$ & $<94$ & $n / a$ & $n / a$ & $n / a$ \\
\hline $\mathrm{K}$ & $\mathrm{ug} / \mathrm{mL}$ & (ADS)FP & $\mathrm{n} / \mathrm{a}$ & $\mathrm{n} / \mathrm{a}$ & $992 \mathrm{ppm}$ & $494 \mathrm{ppm}$ & $\mathrm{n} / \mathrm{a}$ & 31 & $n / a$ & $\mathrm{n} / \mathrm{a}$ & $n / a$ \\
\hline $\mathrm{K}(\mathrm{AA})$ & $\mathrm{ug} / \mathrm{mL}$ & (ADS)SB & $\mathrm{n} / \mathrm{a}$ & $n / a$ & $836.69 \mathrm{ppm}$ & $235.41 \mathrm{ppm}$ & $\mathrm{n} / \mathrm{a}$ & 31.12 & $n / a$ & $\mathrm{n} / \mathrm{a}$ & $n / a$ \\
\hline $\mathrm{La}$ & $\mathrm{ug} / \mathrm{mL}$ & (ADS)FP & $\mathrm{n} / \mathrm{a}$ & $n / a$ & $<350 \mathrm{ppm}$ & $<350 \mathrm{ppm}$ & $n / a$ & $<7$ & $n / a$ & $n / a$ & $n / a$ \\
\hline$\overline{L i}$ & $\mathrm{ug} / \mathrm{mL}$ & (ADS)FP & $\mathrm{n} / \mathrm{a}$ & $n / a$ & $<50 \mathrm{ppm}$ & $<50 \mathrm{ppm}$ & $n / a$ & $<1$ & $n / a$ & $n / a$ & $n / a$ \\
\hline$\overline{M g}$ & $\mathrm{ug} / \mathrm{mL}$ & (ADS)FP & $\mathrm{n} / \mathrm{a}$ & $n / a$ & $355 \mathrm{ppm}$ & $442 \mathrm{ppm}$ & $n / a$ & $<0.84$ & $n / a$ & $n / a$ & $n / a$ \\
\hline $\mathrm{Mn}$ & $\mathrm{ug} / \mathrm{mL}$ & (ADS)FP & $\mathrm{n} / \mathrm{a}$ & $n / a$ & $241 \mathrm{ppm}$ & $275 \mathrm{ppm}$ & $n / a$ & $<0.09$ & $n / a$ & $n / a$ & $n / a$ \\
\hline Mo & $\mathrm{ug} / \mathrm{mL}$ & (ADS)FP & $\mathrm{n} / \mathrm{a}$ & $n / a$ & $<50 \mathrm{ppm}$ & $<50 \mathrm{ppm}$ & $n / a$ & $<1$ & $n / a$ & $n / a$ & $n / a$ \\
\hline $\mathrm{Na}$ & $\mathrm{ug} / \mathrm{mL}$ & (ADS)FP & $n / a$ & $n / a$ & $\mathrm{n} / \mathrm{a}$ & $61700 \mathrm{ppm}$ & $\mathrm{n} / \mathrm{a}$ & 70958 & $\mathrm{n} / \mathrm{a}$ & $\mathrm{n} / \mathrm{a}$ & $n / a$ \\
\hline $\mathrm{Nd}$ & $\mathrm{ug} / \mathrm{mL}$ & (ADS)FP & $n / a$ & $n / a$ & $\mathrm{n} / \mathrm{a}$ & n/a & $\mathrm{n} / \mathrm{a}$ & $\mathrm{n} / \mathrm{a}$ & $n / a$ & $n / a$ & $n / a$ \\
\hline $\mathrm{Ni}$ & $\mathrm{ug} / \mathrm{mL}$ & (ADS)FP & $n / a$ & $\mathrm{n} / \mathrm{a}$ & $78 \mathrm{ppm}$ & $<30 \mathrm{ppm}$ & $\mathrm{n} / \mathrm{a}$ & 0.89 & $n / a$ & $n / a$ & $n / a$ \\
\hline NO2 (Nitrite) & $\mathrm{ug} / \mathrm{mL}$ & (ADS)RR\&JC & $n / a$ & $<473 \mathrm{ppm}$ & $\mathrm{n} / \mathrm{a}$ & $\mathrm{n} / \mathrm{a}$ & $<89^{* \star}$ & $<94$ & $n / a$ & $n / a$ & $n / a$ \\
\hline NO3 (Nitrate) & $\mathrm{ug} / \mathrm{mL}$ & (ADS)RR\&JC & $n / a$ & $1468 \mathrm{ppm}$ & $\mathrm{n} / \mathrm{a}$ & $\mathrm{n} / \mathrm{a}$ & $29^{* *}$ & 49 & $\mathrm{n} / \mathrm{a}$ & $\mathrm{n} / \mathrm{a}$ & $\mathrm{n} / \mathrm{a}$ \\
\hline C2O4 (Oxalate) & $\mathrm{ug} / \mathrm{mL}$ & (ADS)RR\&JC & $\mathrm{n} / \mathrm{a}$ & $<473 \mathrm{ppm}$ & $\mathrm{n} / \mathrm{a}$ & $\mathrm{n} / \mathrm{a}$ & $<89^{* *}$ & $<94$ & $\mathrm{n} / \mathrm{a}$ & $\mathrm{n} / \mathrm{a}$ & $n / a$ \\
\hline $\mathrm{P}$ & $\mathrm{ug} / \mathrm{mL}$ & (ADS)FP & $\mathrm{n} / \mathrm{a}$ & $\mathrm{n} / \mathrm{a}$ & $<350 \mathrm{ppm}$ & $<350 \mathrm{ppm}$ & $\mathrm{n} / \mathrm{a}$ & 16 & $n / a$ & $n / a$ & $n / a$ \\
\hline$\overline{\mathrm{PO} 4 \text { (Phosphate) }}$ & $\mathrm{ug} / \mathrm{mL}$ & (ADS)RR\&JC & $\mathrm{n} / \mathrm{a}$ & $813 \mathrm{ppm}$ & $\mathrm{n} / \mathrm{a}$ & $\mathrm{n} / \mathrm{a}$ & $21^{* *}$ & 41 & $n / a$ & $n / a$ & $n / a$ \\
\hline $\mathrm{Pb}$ & $\mathrm{ug} / \mathrm{mL}$ & (ADS)FP & $\mathrm{n} / \mathrm{a}$ & $\mathrm{n} / \mathrm{a}$ & $<350 \mathrm{ppm}$ & $<350 \mathrm{ppm}$ & $\mathrm{n} / \mathrm{a}$ & $<8.0$ & $n / a$ & $n / a$ & $n / a$ \\
\hline $\mathrm{s}$ & $\mathrm{ug} / \mathrm{mL}$ & (ADS)FP & $\mathrm{n} / \mathrm{a}$ & $n / a$ & $<300 \mathrm{ppm}$ & $<300 \mathrm{p}[\mathrm{pm}$ & $n / a$ & $<5$ & $n / a$ & $n / a$ & $n / a$ \\
\hline Si & $\mathrm{ug} / \mathrm{mL}$ & (ADS)FP & $\mathrm{n} / \mathrm{a}$ & $n / a$ & $6630 \mathrm{ppm}$ & $1029 \mathrm{ppm}$ & $\mathrm{n} / \mathrm{a}$ & 37.5 & $n / a$ & $\mathrm{n} / \mathrm{a}$ & $\mathrm{n} / \mathrm{a}$ \\
\hline $\mathrm{Sn}$ & $\mathrm{ug} / \mathrm{mL}$ & (ADS)FP & $\mathrm{n} / \mathrm{a}$ & $n / a$ & $<150 \mathrm{ppm}$ & $<150 \mathrm{ppm}$ & $\mathrm{n} / \mathrm{a}$ & $<2.6$ & $\mathrm{n} / \mathrm{a}$ & $\mathrm{n} / \mathrm{a}$ & $n / a$ \\
\hline SO4 (Sulfate) & $\mathrm{ug} / \mathrm{mL}$ & (ADS)RR\&JC & $\mathrm{n} / \mathrm{a}$ & $898 \mathrm{ppm}$ & $n / a$ & $\mathrm{n} / \mathrm{a}$ & $13^{* \star}$ & 28 & $\mathrm{n} / \mathrm{a}$ & $\mathrm{n} / \mathrm{a}$ & $n / a$ \\
\hline $\mathrm{Sr}$ & $\mathrm{ug} / \mathrm{mL}$ & (ADS)FP & $\mathrm{n} / \mathrm{a}$ & $\mathrm{n} / \mathrm{a}$ & $<80 \mathrm{ppm}$ & $<80 \mathrm{ppm}$ & $\mathrm{n} / \mathrm{a}$ & $<0.02$ & $\mathrm{n} / \mathrm{a}$ & $n / a$ & $n / a$ \\
\hline $\mathrm{Ti}$ & $\mathrm{ug} / \mathrm{mL}$ & (ADS)FP & $\mathrm{n} / \mathrm{a}$ & $n / a$ & $137 \mathrm{ppm}$ & $93 \mathrm{ppm}$ & $\mathrm{n} / \mathrm{a}$ & $<1.4$ & $n / a$ & $\mathrm{n} / \mathrm{a}$ & $n / a$ \\
\hline $\mathrm{V}$ & $\mathrm{ug} / \mathrm{mL}$ & (ADS)FP & $\mathrm{n} / \mathrm{a}$ & $\mathrm{n} / \mathrm{a}$ & $<75 \mathrm{ppm}$ & $<75 \mathrm{ppm}$ & $\mathrm{n} / \mathrm{a}$ & $<1.3$ & $\mathrm{n} / \mathrm{a}$ & $\mathrm{n} / \mathrm{a}$ & $n / a$ \\
\hline $\mathrm{W}$ & $\mathrm{ug} / \mathrm{mL}$ & (ADS)FP & $\mathrm{n} / \mathrm{a}$ & $n / a$ & $76.7 \mathrm{ppm}$ & $286 \mathrm{ppm}$ & $\mathrm{n} / \mathrm{a}$ & 67.7 & $\mathrm{n} / \mathrm{a}$ & $\mathrm{n} / \mathrm{a}$ & $\mathrm{n} / \mathrm{a}$ \\
\hline $\mathrm{Zn}$ & $\mathrm{ug} / \mathrm{mL}$ & (ADS)FP & $\mathrm{n} / \mathrm{a}$ & $\mathrm{n} / \mathrm{a}$ & $<180 \mathrm{ppm}$ & $<180 \mathrm{ppm}$ & $\mathrm{n} / \mathrm{a}$ & 12.4 & $\mathrm{n} / \mathrm{a}$ & $\mathrm{n} / \mathrm{a}$ & $n / a$ \\
\hline $\mathrm{Zr}$ & $\mathrm{ug} / \mathrm{mL}$ & (ADS)FP & $\mathrm{n} / \mathrm{a}$ & $n / a$ & $n / a$ & $16300 \mathrm{ppm}$ & $\mathrm{n} / \mathrm{a}$ & 3.66 & $\mathrm{n} / \mathrm{a}$ & $\mathrm{n} / \mathrm{a}$ & $n / a$ \\
\hline Total Organic Carbon & $\mathrm{ug} / \mathrm{mL}$ & $(\mathrm{ADS}) \mathrm{BC}$ & $\mathrm{n} / \mathrm{a}$ & $\mathrm{n} / \mathrm{a}$ & $\mathrm{n} / \mathrm{a}$ & $\mathrm{n} / \mathrm{a}$ & 2190.00 & $\mathrm{n} / \mathrm{a}$ & $\mathrm{n} / \mathrm{a}$ & $\mathrm{n} / \mathrm{a}$ & $\mathrm{n} / \mathrm{a}$ \\
\hline Total Inorganic Carbon & $\mathrm{ug} / \mathrm{mL}$ & $(\mathrm{ADS}) \mathrm{BC}$ & $\mathrm{n} / \mathrm{a}$ & $\mathrm{n} / \mathrm{a}$ & $\mathrm{n} / \mathrm{a}$ & $\mathrm{n} / \mathrm{a}$ & $<10$ & $\mathrm{n} / \mathrm{a}$ & $\mathrm{n} / \mathrm{a}$ & $\mathrm{n} / \mathrm{a}$ & $\mathrm{n} / \mathrm{a}$ \\
\hline Suspended Solids & $w+\%$ & (ADS)BB\&TNX & 19.5 & $\mathrm{n} / \mathrm{a}$ & $\mathrm{n} / \mathrm{a}$ & $\mathrm{n} / \mathrm{a}$ & $\mathrm{n} / \mathrm{a}$ & $\mathrm{n} / \mathrm{a}$ & 19.8 & $\mathrm{n} / \mathrm{a}$ & $\mathrm{n} / \mathrm{a}$ \\
\hline Total Solids & $\mathrm{wt} \%$ & (ADS)BB \& TNX & 33.2 & $n / a$ & $\mathrm{n} / \mathrm{a}$ & $n / a$ & $\mathrm{n} / \mathrm{a}$ & $\mathrm{n} / \mathrm{a}$ & 32.1 & $\mathrm{n} / \mathrm{a}$ & $\mathrm{n} / \mathrm{a}$ \\
\hline Mean Particle Size by Volume & micron & $(\mathrm{ADS}) \mathrm{DB}$ & $\mathrm{n} / \mathrm{a}$ & $\mathrm{n} / \mathrm{a}$ & $\mathrm{n} / \mathrm{a}$ & $n / a$ & $\mathrm{n} / \mathrm{a}$ & $\mathrm{n} / \mathrm{a}$ & $\mathrm{n} / \mathrm{a}$ & see below & $\mathrm{n} / \mathrm{a}$ \\
\hline Mean Particle Size by Number & micron & (ADS)DB & $\mathrm{n} / \mathrm{a}$ & $\mathrm{n} / \mathrm{a}$ & $\mathrm{n} / \mathrm{a}$ & $\mathrm{n} / \mathrm{a}$ & $\mathrm{n} / \mathrm{a}$ & $\mathrm{n} / \mathrm{a}$ & $\mathrm{n} / \mathrm{a}$ & 1.05 & $\mathrm{n} / \mathrm{a}$ \\
\hline 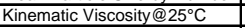 & \begin{tabular}{|l|} 
centistoke \\
\end{tabular} & (TNX)EH & $\mathrm{n} / \mathrm{a}$ & $\mathrm{n} / \mathrm{a}$ & $\mathrm{n} / \mathrm{a}$ & $\mathrm{n} / \mathrm{a}$ & 1.90 & $\mathrm{n} / \mathrm{a}$ & $\mathrm{n} / \mathrm{a}$ & $\mathrm{n} / \mathrm{a}$ & $\mathrm{n} / \mathrm{a}$ \\
\hline Dyn Visc / Consistency@25 $5^{\circ} \mathrm{C}$ & \begin{tabular}{|l|}
$\mathrm{CP}$ \\
\end{tabular} & (TNX)EH EH & 3.6 & $\mathrm{n} / \mathrm{a}$ & $\mathrm{n} / \mathrm{a}$ & $n / a$ & $2.21^{*}$ & $\mathrm{n} / \mathrm{a}$ & $\mathrm{n} / \mathrm{a}$ & $\mathrm{n} / \mathrm{a}$ & $n / a$ \\
\hline 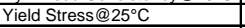 & $\mathrm{Pa}$ & (TNX)EH & 1.2 & $\mathrm{n} / \mathrm{a}$ & $\mathrm{n} / \mathrm{a}$ & $\mathrm{n} / \mathrm{a}$ & $0^{*}$ & $\mathrm{n} / \mathrm{a}$ & $\mathrm{n} / \mathrm{a}$ & $\mathrm{n} / \mathrm{a}$ & $\mathrm{n} / \mathrm{a}$ \\
\hline Dyn Visc / Consistency@50C & $\mathrm{CP}$ & (TNX)EH & 2.3 & $\mathrm{n} / \mathrm{a}$ & $\mathrm{n} / \mathrm{a}$ & $\mathrm{n} / \mathrm{a}$ & $1.27^{*}$ & $\mathrm{n} / \mathrm{a}$ & $\mathrm{n} / \mathrm{a}$ & $\mathrm{n} / \mathrm{a}$ & $\mathrm{n} / \mathrm{a}$ \\
\hline Yield Stress@50 $\mathrm{C}$ & $\mathrm{Pa}$ & (TNX)EH & 1.0 & $\mathrm{n} / \mathrm{a}$ & $\mathrm{n} / \mathrm{a}$ & $\mathrm{n} / \mathrm{a}$ & $0^{*}$ & $\mathrm{n} / \mathrm{a}$ & $\mathrm{n} / \mathrm{a}$ & $\mathrm{n} / \mathrm{a}$ & $n / a$ \\
\hline $\mathrm{pH}$ & none & (ADS)BB\&(TNX)EH & 13.77 & $n / a$ & $\mathrm{n} / \mathrm{a}$ & $n / a$ & $\mathrm{n} / \mathrm{a}$ & $\mathrm{n} / \mathrm{a}$ & $\mathrm{n} / \mathrm{a}$ & $\mathrm{n} / \mathrm{a}$ & $\mathrm{n} / \mathrm{a}$ \\
\hline Corrosivity & none & (F-Area)SB & $\mathrm{n} / \mathrm{a}$ & $\mathrm{n} / \mathrm{a}$ & $\mathrm{n} / \mathrm{a}$ & $\mathrm{n} / \mathrm{a}$ & $\mathrm{n} / \mathrm{a}$ & $\mathrm{n} / \mathrm{a}$ & $\mathrm{n} / \mathrm{a}$ & $\mathrm{n} / \mathrm{a}$ & corrosive $^{*}$ \\
\hline \multirow[t]{3}{*}{$\begin{array}{l}\text { COLUMN-RELATED } \\
\text { COMMENTS }\end{array}$} & $\begin{array}{l}\text { *Units of } \\
\text { entries } \\
\text { unless } \\
\text { otherwise } \\
\text { noted }\end{array}$ & \multirow{3}{*}{\multicolumn{2}{|c|}{$\begin{array}{l}\text { Analyst Names } \\
\mathrm{DB}=\text { Don Blankenship } \\
\mathrm{SB}=\text { Sarah Brown } \\
\mathrm{BB}=\text { Beverly Burch } \\
\mathrm{SB}=\text { Syderis Burkett } \\
\mathrm{JC}=\text { Joyce Cartledge } \\
\mathrm{BC}=\mathrm{B} . \mathrm{S} . \text { Carter } \\
\mathrm{EH}=\text { Erick Hansen } \\
\mathrm{FP}=\text { Frank Pennebaker }\end{array}$}} & $\begin{array}{l}\text { Note: Not all } \\
\text { three dissolut } \\
\text { used because } \\
\text { done. For ins } \\
\text { a zinc crucibl } \\
\text { gives a usabl } \\
\text { Preferred val }\end{array}$ & $\begin{array}{l}\text { the results for } \\
\text { tion methods } \\
\text { e of the way th } \\
\text { tance, } 1 \& 2 \text { are } \\
\text { e so only met } \\
\text { le value for } Z \text { r. } \\
\text { ues are shade }\end{array}$ & $\begin{array}{l}\text { these three } \\
\text { can be } \\
\text { ey are } \\
\text { e done in } \\
\text { thod } 3 \\
\text { dike }\end{array}$ & $\begin{array}{l}\text { *supernate } \\
\text { viscosity } \\
\text { came from } \\
\text { the TNX } \\
\text { sample } \\
{ }^{* \star} \text { IC Anions } \\
\text { were }\end{array}$ & $\begin{array}{l}{ }^{*} \text { The test for } \\
\text { Tungsten } \\
\text { can measure } \\
\text { solids that } \\
\text { were in the } \\
\text { supernatant. } \\
\text { Filtering may }\end{array}$ & & $\begin{array}{l}{ }^{*} \text { The volume } \\
\text { distribution } \\
\text { had three } \\
\text { peaks } \\
\text { micons }(\% \text { total }) \\
2.00(43 \%) \\
5.60(14 \%)\end{array}$ & $\begin{array}{l}\text { Corrositex } \\
\text { test indicated } \\
\text { a sample } \\
\text { Category } 1 \\
\text { and a } \\
\text { Package } \\
\text { Group II for }\end{array}$ \\
\hline & & & & the one shov & vn here. $\gg$ [ & & measured & leave solids & & $18.28(43 \%)$ & shipping \\
\hline & & & & & & & in sample & $<5$ microns. & & & \\
\hline $\begin{array}{l}\text { COLUMN-RELATED } \\
\text { COMMENTS }\end{array}$ & $\begin{array}{l}\text { *Units of } \\
\text { entries }\end{array}$ & $\frac{\text { Analyst Names }}{\mathrm{DB}=\text { Don Blankenship }}$ & & $\begin{array}{l}\text { Note: Not all } \\
\text { three dissolut }\end{array}$ & $\begin{array}{l}\text { the results for } \\
\text { tion methods c }\end{array}$ & $\begin{array}{l}\text { these three } \\
\text { can be }\end{array}$ & $\begin{array}{l}\text { *supernate } \\
\text { viscosity }\end{array}$ & $\begin{array}{l}{ }^{*} \text { The test for } \\
\text { Tungsten }\end{array}$ & & $\begin{array}{l}\text { *The volume } \\
\text { distribution }\end{array}$ & $\begin{array}{l}\text { Corrositex } \\
\text { test indicated }\end{array}$ \\
\hline & unless & $\mathrm{SB}=$ Sarah Brown & density of & used because & of the way th & ey are & came from & can measure & & had three & a sample \\
\hline & $\begin{array}{l}\text { otherwise } \\
\text { noted }\end{array}$ & $\begin{array}{l}\mathrm{BB}=\text { Beverly Burch } \\
\mathrm{SB}=\text { Syderis Burkett }[\mathrm{n}\end{array}$ & $\begin{array}{l}\text { supernate as } \\
\text { measured }\end{array}$ & 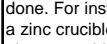 & $\begin{array}{l}\text { tance, } 1 \& 2 \text { are } \\
\text { e so only mett }\end{array}$ & $\begin{array}{l}\text { e done in } \\
\text { thod } 3\end{array}$ & $\begin{array}{l}\text { the TNX } \\
\text { sample }\end{array}$ & $\begin{array}{l}\text { solids that } \\
\text { were in the }\end{array}$ & & $\begin{array}{l}\text { peaks } \\
\text { micons(\%total) }\end{array}$ & $\begin{array}{l}\text { Category } 1 \\
\text { and a }\end{array}$ \\
\hline & & $\begin{array}{l}\mathrm{JC}=\text { Joyce Cartledge } \mathrm{b} \\
\mathrm{BC}=\text { B.S. Carter }\end{array}$ & $\begin{array}{l}\text { by NTX }= \\
\text { pending }\end{array}$ & $\begin{array}{l}\text { gives a usabl } \\
\text { Preferred val }\end{array}$ & $\begin{array}{l}\text { le value for } Z r \text {. } \\
\text { ues are shade }\end{array}$ & ed like & $\begin{array}{l}* \star I C \text { Anions } \\
\text { were }\end{array}$ & $\begin{array}{l}\text { supernatant. } \\
\text { Filtering may }\end{array}$ & & $\begin{array}{l}2.00(43 \%) \\
5.60(14 \%)\end{array}$ & $\begin{array}{l}\text { Package } \\
\text { Group II for }\end{array}$ \\
\hline & & $\mathrm{EH}=$ Erick Hansen & & the one shov & $w n$ here. $>>$ & & measured & $\begin{array}{l}\text { Filtering may } \\
\text { leave solids }\end{array}$ & & $\begin{array}{l}5.60(14 \%) \\
18.28(43 \%)\end{array}$ & \\
\hline & & $\mathrm{FP}=$ Frank Pennebake & & & & & in sample & $<5$ microns. & & & \\
\hline & & $\mathrm{RR}=$ Robert Ray & & & & & 300170804 by & & & & \\
\hline & & $\mathrm{TNX}=\mathrm{A}$ laboratory at & t SRS & & & & instead of ISE & & & & \\
\hline & & ADS $=$ Analytical Devel & elopment Secti & tion at SRS & & & because that & & & & \\
\hline & & & & & & & $\begin{array}{l}\text { test was } \\
\text { discontinued. }\end{array}$ & & & & \\
\hline
\end{tabular}

Analysis Nomenclature

= Dissolution - Sodium Peroxide $/$ uptake with Water $\quad 4=\mathrm{CL}-$ Ion Selective Emission

$3=$ Dissolution with Aquaregent $-25 \%$ Nitric Acid and $75 \% \mathrm{HCL} \quad 6=\mathrm{ICP}-\mathrm{ES}$ 
Table A6. RPP-WTP Hanford Waste Simulant: Washed HLW (AZ-101)

\begin{tabular}{|c|c|c|c|c|c|c|c|c|c|c|c|}
\hline & \multirow{5}{*}{$\begin{array}{c}\text { Slurry --a-------->> } \\
\text { ILWwashed_) ------>> } \\
\text { ADS Sample ID -->> } \\
\text { Type Sample ---->> } \\
\text { Sample Size }(\mathrm{mL})>>\end{array}$} & \multirow{3}{*}{$\begin{array}{c}\text { HLWwashed } \\
\text { Prefix+1 } \\
\text { None-TNX }\end{array}$} & \multirow{3}{*}{$\begin{array}{c}\text { HLWwashed } \\
\text { Prefix+2 } \\
300161853\end{array}$} & \multirow{3}{*}{$\begin{array}{l}\text { HLWwashed } \\
\text { Prefix }+3 \\
300161854\end{array}$} & HLWwashed & HLWwashed & HLWwashed & HLWwashed & HLWwashed & HLWwashed \\
\hline \multirow{4}{*}{\multicolumn{2}{|c|}{$\begin{array}{l}\text { Most Recent Entry Date: } 16-J u l y-2001 \\
\text { RPP Sample ID (Prefix = RPP-FILT139-HL }\end{array}$}} & & & & & Prefix +4 & Prefix +5 & Prefix+6 & Prefix +7 & Prefix+8 & Prefix +9 \\
\hline & & & & & & 300161855 & 300161856 & 300161857 & 300161858 & 300161859 & 200148456 \\
\hline & & & & & & & & & & & slurry-20 wt\% \\
\hline & & & 250 & 15 & 15 & 15 & 15 & 15 & 10 & 15 & 15 \\
\hline Measurement Made (NUMBER & IS ARE EXP & PLAINED BELOW) $\gg$ & Rheology* & $1,4,5,9$ & $2,6,7$ & $3,6,7$ & $4,5,8,13,14$ & $6,7,9$ & 10,11 & MICROTRAC & Corrosivity \\
\hline Item Measured & Units $^{*}$ & (Lab)Analyst & & & & & & & & & \\
\hline Density & $\mathrm{g} / \mathrm{mL}$ & (ADS)BB\&TNX(EH) & $1.174^{\star \star \star \star}$ & $\mathrm{n} / \mathrm{a}$ & $\mathrm{n} / \mathrm{a}$ & 1.16 & $\ll<n / a$ & $\mathrm{n} / \mathrm{a}$ & $\mathrm{n} / \mathrm{a}$ & $\mathrm{n} / \mathrm{a}$ & $\mathrm{n} / \mathrm{a}$ \\
\hline$\overline{\mathrm{Ag}}$ & $\mathrm{ug} / \mathrm{mL}$ & (ADS)FP & $\mathrm{n} / \mathrm{a}$ & $\mathrm{n} / \mathrm{a}$ & $<120 \mathrm{ppm}$ & $<120 \mathrm{ppm}$ & $\mathrm{n} / \mathrm{a}$ & $<0.3$ & $\mathrm{n} / \mathrm{a}$ & $\mathrm{n} / \mathrm{a}$ & $\mathrm{n} / \mathrm{a}$ \\
\hline$\overline{\mathrm{Al}}$ & $\mathrm{ug} / \mathrm{mL}$ & (ADS)FP & $\mathrm{n} / \mathrm{a}$ & $\mathrm{n} / \mathrm{a}$ & $16300 \mathrm{ppm}$ & $16200 \mathrm{ppm}$ & $\mathrm{n} / \mathrm{a}$ & $<0.24$ & $\mathrm{n} / \mathrm{a}$ & $\mathrm{n} / \mathrm{a}$ & $\mathrm{n} / \mathrm{a}$ \\
\hline $\mathrm{B}$ & $\mathrm{ug} / \mathrm{mL}$ & (ADS)FP & $\mathrm{n} / \mathrm{a}$ & $\mathrm{n} / \mathrm{a}$ & $185 \mathrm{ppm}$ & $170 \mathrm{ppm}$ & $\mathrm{n} / \mathrm{a}$ & $<0.21$ & $\mathrm{n} / \mathrm{a}$ & $\mathrm{n} / \mathrm{a}$ & $\mathrm{n} / \mathrm{a}$ \\
\hline$\overline{\mathrm{Ba}}$ & $\mathrm{ug} / \mathrm{mL}$ & (ADS)FP & $\mathrm{n} / \mathrm{a}$ & $\mathrm{n} / \mathrm{a}$ & $<5.0 \mathrm{ppm}$ & $<5.0 \mathrm{ppm}$ & $\mathrm{n} / \mathrm{a}$ & $<0.012$ & $\mathrm{n} / \mathrm{a}$ & $\mathrm{n} / \mathrm{a}$ & $\mathrm{n} / \mathrm{a}$ \\
\hline$\overline{\mathrm{Ca}}$ & $\mathrm{ug} / \mathrm{mL}$ & $(\mathrm{ADS}) \mathrm{FP}$ & $\mathrm{n} / \mathrm{a}$ & $\mathrm{n} / \mathrm{a}$ & $940 \mathrm{ppm}$ & $255 \mathrm{ppm}$ & $\mathrm{n} / \mathrm{a}$ & 0.92 & $\mathrm{n} / \mathrm{a}$ & $\mathrm{n} / \mathrm{a}$ & $\mathrm{n} / \mathrm{a}$ \\
\hline$\overline{\mathrm{Ce}}$ & $\mathrm{ug} / \mathrm{mL}$ & (ADS)FP & $\mathrm{n} / \mathrm{a}$ & $\mathrm{n} / \mathrm{a}$ & $<300 \mathrm{ppm}$ & $<300 \mathrm{ppm}$ & $\mathrm{n} / \mathrm{a}$ & $<0.5$ & $\mathrm{n} / \mathrm{a}$ & $\mathrm{n} / \mathrm{a}$ & $\mathrm{n} / \mathrm{a}$ \\
\hline$\overline{\mathrm{Cd}}$ & $\mathrm{ug} / \mathrm{mL}$ & (ADS)FP & $\mathrm{n} / \mathrm{a}$ & $\mathrm{n} / \mathrm{a}$ & $<10 \mathrm{ppm}$ & $<10 \mathrm{ppm}$ & $\mathrm{n} / \mathrm{a}$ & $<0.014$ & $\mathrm{n} / \mathrm{a}$ & $\mathrm{n} / \mathrm{a}$ & $\mathrm{n} / \mathrm{a}$ \\
\hline$\overline{\mathrm{Cl} \text { (Chloride) [less accurate] }}$ & $\mathrm{ug} / \mathrm{mL}$ & $($ ADS $) J C$ & $\mathrm{n} / \mathrm{a}$ & $<2$ & $\mathrm{n} / \mathrm{a}$ & $\mathrm{n} / \mathrm{a}$ & $\mathrm{n} / \mathrm{a}$ & 3 & $\mathrm{n} / \mathrm{a}$ & $\mathrm{n} / \mathrm{a}$ & $\mathrm{n} / \mathrm{a}$ \\
\hline Cl Sample & $\mathrm{ug} / \mathrm{mL}$ & $(\mathrm{ADS}) \mathrm{BC}$ & $\mathrm{n} / \mathrm{a}$ & $<5$ & $\mathrm{n} / \mathrm{a}$ & $\mathrm{n} / \mathrm{a}$ & 40.2 & $\mathrm{n} / \mathrm{a}$ & $\mathrm{n} / \mathrm{a}$ & $\mathrm{n} / \mathrm{a}$ & $\mathrm{n} / \mathrm{a}$ \\
\hline Co & $\mathrm{ug} / \mathrm{mL}$ & (ADS)FP & $\mathrm{n} / \mathrm{a}$ & $\mathrm{n} / \mathrm{a}$ & $<20 \mathrm{ppm}$ & $<20 \mathrm{ppm}$ & $\mathrm{n} / \mathrm{a}$ & $<0.044$ & $\mathrm{n} / \mathrm{a}$ & $\mathrm{n} / \mathrm{a}$ & $\mathrm{n} / \mathrm{a}$ \\
\hline$\overline{\mathrm{Cr}}$ & $\mathrm{ug} / \mathrm{mL}$ & (ADS)FP & $\mathrm{n} / \mathrm{a}$ & $\mathrm{n} / \mathrm{a}$ & $65 \mathrm{ppm}$ & $<20 \mathrm{ppm}$ & $\mathrm{n} / \mathrm{a}$ & 0.12 & $\mathrm{n} / \mathrm{a}$ & $\mathrm{n} / \mathrm{a}$ & $\mathrm{n} / \mathrm{a}$ \\
\hline $\mathrm{Cu}$ & $\mathrm{ug} / \mathrm{mL}$ & (ADS)FP & $\mathrm{n} / \mathrm{a}$ & $\mathrm{n} / \mathrm{a}$ & $<20 \mathrm{ppm}$ & $<20 \mathrm{ppm}$ & $\mathrm{n} / \mathrm{a}$ & $<0.05$ & $\mathrm{n} / \mathrm{a}$ & $\mathrm{n} / \mathrm{a}$ & $\mathrm{n} / \mathrm{a}$ \\
\hline $\bar{F}$ (Fluoride) [less accurate] & $\mathrm{ug} / \mathrm{mL}$ & (ADS)JC & $\mathrm{n} / \mathrm{a}$ & $<2$ & $\mathrm{n} / \mathrm{a}$ & $\mathrm{n} / \mathrm{a}$ & $\mathrm{n} / \mathrm{a}$ & 0.5 & $\mathrm{n} / \mathrm{a}$ & $\mathrm{n} / \mathrm{a}$ & $\mathrm{n} / \mathrm{a}$ \\
\hline F Sample (more accurate resul & $\mathrm{ug} / \mathrm{mL}$ & (ADS)BC & $\mathrm{n} / \mathrm{a}$ & $<5$ & $\mathrm{n} / \mathrm{a}$ & $\mathrm{n} / \mathrm{a}$ & 2.29 & $\mathrm{n} / \mathrm{a}$ & $\mathrm{n} / \mathrm{a}$ & $\mathrm{n} / \mathrm{a}$ & $\mathrm{n} / \mathrm{a}$ \\
\hline $\mathrm{Fe}$ & $\mathrm{ug} / \mathrm{mL}$ & (ADS)FP & $\mathrm{n} / \mathrm{a}$ & $\mathrm{n} / \mathrm{a}$ & $56400 \mathrm{ppm}$ & $60500 \mathrm{ppm}$ & $\mathrm{n} / \mathrm{a}$ & 7.28 & $\mathrm{n} / \mathrm{a}$ & $\mathrm{n} / \mathrm{a}$ & $\mathrm{n} / \mathrm{a}$ \\
\hline HCOO (Formate) & $\mathrm{ug} / \mathrm{mL}$ & (ADS)RR\&JC & $\mathrm{n} / \mathrm{a}$ & $<10$ & $\mathrm{n} / \mathrm{a}$ & $\mathrm{n} / \mathrm{a}$ & $\mathrm{n} / \mathrm{a}$ & 0.7 & $\mathrm{n} / \mathrm{a}$ & $\mathrm{n} / \mathrm{a}$ & $\mathrm{n} / \mathrm{a}$ \\
\hline $\mathrm{K}$ & $\mathrm{ug} / \mathrm{mL}$ & (ADS)FP & $\mathrm{n} / \mathrm{a}$ & $\mathrm{n} / \mathrm{a}$ & $1057 \mathrm{ppm}$ & $351 \mathrm{ppm}$ & $\mathrm{n} / \mathrm{a}$ & 8.45 & $\mathrm{n} / \mathrm{a}$ & $n / a$ & $\mathrm{n} / \mathrm{a}$ \\
\hline $\mathrm{K}(\mathrm{AA})$ & $\mathrm{ug} / \mathrm{mL}$ & (ADS)SB & $\mathrm{n} / \mathrm{a}$ & $\mathrm{n} / \mathrm{a}$ & 220.58 & 181.21 & $\mathrm{n} / \mathrm{a}$ & 359.09 & $\mathrm{n} / \mathrm{a}$ & $n / a$ & $\mathrm{n} / \mathrm{a}$ \\
\hline La & $\mathrm{ug} / \mathrm{mL}$ & (ADS)FP & $\mathrm{n} / \mathrm{a}$ & $\mathrm{n} / \mathrm{a}$ & $<300 \mathrm{ppm}$ & $<300 \mathrm{ppm}$ & $\mathrm{n} / \mathrm{a}$ & $<0.7$ & $\mathrm{n} / \mathrm{a}$ & $\mathrm{n} / \mathrm{a}$ & $\mathrm{n} / \mathrm{a}$ \\
\hline$\overline{\mathrm{Li}}$ & $\mathrm{ug} / \mathrm{mL}$ & (ADS)FP & $\mathrm{n} / \mathrm{a}$ & $\mathrm{n} / \mathrm{a}$ & $<40 \mathrm{ppm}$ & $<40 \mathrm{ppm}$ & $\mathrm{n} / \mathrm{a}$ & $<0.1$ & $\mathrm{n} / \mathrm{a}$ & $n / a$ & $n / a$ \\
\hline$\overline{\mathrm{Mg}}$ & $\mathrm{ug} / \mathrm{mL}$ & (ADS)FP & $\mathrm{n} / \mathrm{a}$ & $\mathrm{n} / \mathrm{a}$ & $371 \mathrm{ppm}$ & $301 \mathrm{ppm}$ & $\mathrm{n} / \mathrm{a}$ & $<0.7$ & $\mathrm{n} / \mathrm{a}$ & $\mathrm{n} / \mathrm{a}$ & $\mathrm{n} / \mathrm{a}$ \\
\hline$\overline{\mathrm{Mn}}$ & $\mathrm{ug} / \mathrm{mL}$ & (ADS)FP & $\mathrm{n} / \mathrm{a}$ & $\mathrm{n} / \mathrm{a}$ & $177 \mathrm{ppm}$ & $182 \mathrm{ppm}$ & $\mathrm{n} / \mathrm{a}$ & 0.05 & $\mathrm{n} / \mathrm{a}$ & $n / a$ & $\mathrm{n} / \mathrm{a}$ \\
\hline Mo & $\mathrm{ug} / \mathrm{mL}$ & (ADS)FP & $\mathrm{n} / \mathrm{a}$ & $\mathrm{n} / \mathrm{a}$ & $<40 \mathrm{ppm}$ & $<40 \mathrm{ppm}$ & $\mathrm{n} / \mathrm{a}$ & $<0.1$ & $\mathrm{n} / \mathrm{a}$ & $\mathrm{n} / \mathrm{a}$ & $\mathrm{n} / \mathrm{a}$ \\
\hline $\mathrm{Na}$ & $\mathrm{ug} / \mathrm{mL}$ & (ADS)FP & $\mathrm{n} / \mathrm{a}$ & $\mathrm{n} / \mathrm{a}$ & $\mathrm{n} / \mathrm{a}$ & $1720 \mathrm{ppm}$ & $\mathrm{n} / \mathrm{a}$ & 270 & $\mathrm{n} / \mathrm{a}$ & $\mathrm{n} / \mathrm{a}$ & $\mathrm{n} / \mathrm{a}$ \\
\hline $\mathrm{Nd}$ & $\mathrm{ug} / \mathrm{mL}$ & (ADS)FP & $\mathrm{n} / \mathrm{a}$ & $\mathrm{n} / \mathrm{a}$ & $<100 \mathrm{ppm}$ & $<100 \mathrm{ppm}$ & $\mathrm{n} / \mathrm{a}$ & $<2.6$ & $\mathrm{n} / \mathrm{a}$ & $n / a$ & $\mathrm{n} / \mathrm{a}$ \\
\hline $\mathrm{Ni}$ & $\mathrm{ug} / \mathrm{mL}$ & (ADS)FP & $\mathrm{n} / \mathrm{a}$ & $\mathrm{n} / \mathrm{a}$ & $<30 \mathrm{ppm}$ & $<30 \mathrm{ppm}$ & $\mathrm{n} / \mathrm{a}$ & 1.07 & $\mathrm{n} / \mathrm{a}$ & $n / a$ & $\mathrm{n} / \mathrm{a}$ \\
\hline NO2 (Nitrite) & $\mathrm{ug} / \mathrm{mL}$ & (ADS)RR\&JC & $\mathrm{n} / \mathrm{a}$ & $<10$ & $\mathrm{n} / \mathrm{a}$ & $\mathrm{n} / \mathrm{a}$ & $\mathrm{n} / \mathrm{a}$ & 9 & $\mathrm{n} / \mathrm{a}$ & $n / a$ & $n / a$ \\
\hline NO3 (Nitrate) & $\mathrm{ug} / \mathrm{mL}$ & (ADS)RR\&JC & $n / a$ & 6 & $\mathrm{n} / \mathrm{a}$ & $\mathrm{n} / \mathrm{a}$ & $\mathrm{n} / \mathrm{a}$ & 464 & $\mathrm{n} / \mathrm{a}$ & $\mathrm{n} / \mathrm{a}$ & $\mathrm{n} / \mathrm{a}$ \\
\hline C2O4 (Oxalate) & $\mathrm{ug} / \mathrm{mL}$ & (ADS)RR\&JC & $\mathrm{n} / \mathrm{a}$ & $<10$ & $\mathrm{n} / \mathrm{a}$ & $\mathrm{n} / \mathrm{a}$ & $\mathrm{n} / \mathrm{a}$ & $<1$ & $\mathrm{n} / \mathrm{a}$ & $n / a$ & $n / a$ \\
\hline$P$ & $\mathrm{ug} / \mathrm{mL}$ & (ADS)FP & $\mathrm{n} / \mathrm{a}$ & $\mathrm{n} / \mathrm{a}$ & $<300 \mathrm{ppm}$ & $<300 \mathrm{ppm}$ & $\mathrm{n} / \mathrm{a}$ & 1.74 & $\mathrm{n} / \mathrm{a}$ & $\mathrm{n} / \mathrm{a}$ & $\mathrm{n} / \mathrm{a}$ \\
\hline PO4 (Phosphate) & $\mathrm{ug} / \mathrm{mL}$ & (ADS)RR\&JC & $n / a$ & $<10$ & $\mathrm{n} / \mathrm{a}$ & $\mathrm{n} / \mathrm{a}$ & $n / a$ & $<1$ & $\mathrm{n} / \mathrm{a}$ & $n / a$ & $n / a$ \\
\hline $\mathrm{Pb}$ & $\mathrm{ug} / \mathrm{mL}$ & (ADS)FP & $n / a$ & $\mathrm{n} / \mathrm{a}$ & $<300 \mathrm{ppm}$ & $<300 \mathrm{ppm}$ & $\mathrm{n} / \mathrm{a}$ & $<0.69$ & $\mathrm{n} / \mathrm{a}$ & $n / a$ & $n / a$ \\
\hline $\mathrm{s}$ & $\mathrm{ug} / \mathrm{mL}$ & (ADS)FP & $\mathrm{n} / \mathrm{a}$ & $\mathrm{n} / \mathrm{a}$ & $<200 \mathrm{ppm}$ & $<200 \mathrm{ppm}$ & $\mathrm{n} / \mathrm{a}$ & 9.53 & $\mathrm{n} / \mathrm{a}$ & $n / a$ & $\mathrm{n} / \mathrm{a}$ \\
\hline Si & $\mathrm{ug} / \mathrm{mL}$ & (ADS)FP & $n / a$ & $n / a$ & $5500 \mathrm{ppm}$ & $1120 \mathrm{ppm}$ & $n / a$ & 1.58 & $n / a$ & $n / a$ & $n / a$ \\
\hline Sn & $\mathrm{ug} / \mathrm{mL}$ & (ADS)FP & $\mathrm{n} / \mathrm{a}$ & $n / a$ & $<100 \mathrm{ppm}$ & $<100 \mathrm{ppm}$ & $\mathrm{n} / \mathrm{a}$ & $<0.26$ & $\mathrm{n} / \mathrm{a}$ & $n / a$ & $\mathrm{n} / \mathrm{a}$ \\
\hline SO4 (Sulfate) & $\mathrm{ug} / \mathrm{mL}$ & (ADS)RR\&JC & $n / a$ & $<5$ & $n / a$ & $\mathrm{n} / \mathrm{a}$ & $n / a$ & 28 & $\mathrm{n} / \mathrm{a}$ & $n / a$ & $n / a$ \\
\hline Sr & $\mathrm{ug} / \mathrm{mL}$ & (ADS)FP & $\mathrm{n} / \mathrm{a}$ & $n / a$ & $<2.0 \mathrm{ppm}$ & $<2.0 \mathrm{ppm}$ & $\mathrm{n} / \mathrm{a}$ & 0.01 & $\mathrm{n} / \mathrm{a}$ & $\mathrm{n} / \mathrm{a}$ & $\mathrm{n} / \mathrm{a}$ \\
\hline $\mathrm{Ti}$ & $\mathrm{ug} / \mathrm{mL}$ & (ADS)FP & $\mathrm{n} / \mathrm{a}$ & $\mathrm{n} / \mathrm{a}$ & $123 \mathrm{ppm}$ & $71 \mathrm{ppm}$ & $\mathrm{n} / \mathrm{a}$ & $<0.14$ & $\mathrm{n} / \mathrm{a}$ & $\mathrm{n} / \mathrm{a}$ & $\mathrm{n} / \mathrm{a}$ \\
\hline $\mathrm{V}$ & $\mathrm{ug} / \mathrm{mL}$ & (ADS)FP & $\mathrm{n} / \mathrm{a}$ & $\mathrm{n} / \mathrm{a}$ & $<52 \mathrm{ppm}$ & $<52 \mathrm{ppm}$ & $\mathrm{n} / \mathrm{a}$ & $<0.13$ & $\mathrm{n} / \mathrm{a}$ & $\mathrm{n} / \mathrm{a}$ & $\mathrm{n} / \mathrm{a}$ \\
\hline$\overline{\mathrm{W}}$ & $\mathrm{ug} / \mathrm{mL}$ & (ADS)FP & $\mathrm{n} / \mathrm{a}$ & $\mathrm{n} / \mathrm{a}$ & $4760 \mathrm{ppm}$ & $4330 \mathrm{ppm}$ & $\mathrm{n} / \mathrm{a}$ & $252^{*}$ & $\mathrm{n} / \mathrm{a}$ & $n / a$ & $\mathrm{n} / \mathrm{a}$ \\
\hline$\overline{Z n}$ & $\mathrm{ug} / \mathrm{mL}$ & (ADS)FP & $\mathrm{n} / \mathrm{a}$ & $\mathrm{n} / \mathrm{a}$ & $<150 \mathrm{ppm}$ & $<150 \mathrm{ppm}$ & $\mathrm{n} / \mathrm{a}$ & $<0.37$ & $\mathrm{n} / \mathrm{a}$ & $\mathrm{n} / \mathrm{a}$ & $\mathrm{n} / \mathrm{a}$ \\
\hline$\overline{Z r}$ & $\mathrm{ug} / \mathrm{mL}$ & (ADS)FP & $\mathrm{n} / \mathrm{a}$ & $\mathrm{n} / \mathrm{a}$ & $\mathrm{n} / \mathrm{a}$ & $11600 \mathrm{ppm}$ & $\mathrm{n} / \mathrm{a}$ & 0.11 & $\mathrm{n} / \mathrm{a}$ & $\mathrm{n} / \mathrm{a}$ & $\mathrm{n} / \mathrm{a}$ \\
\hline Total Organic Carbon & $\mathrm{ug} / \mathrm{mL}$ & $(\mathrm{ADS}) \mathrm{BC}$ & $\mathrm{n} / \mathrm{a}$ & $\mathrm{n} / \mathrm{a}$ & $\mathrm{n} / \mathrm{a}$ & $\mathrm{n} / \mathrm{a}$ & 35.90 & $\mathrm{n} / \mathrm{a}$ & $\mathrm{n} / \mathrm{a}$ & $\mathrm{n} / \mathrm{a}$ & $\mathrm{n} / \mathrm{a}$ \\
\hline Total Inorganic Carbon & $\mathrm{ug} / \mathrm{mL}$ & $(\mathrm{ADS}) \mathrm{BC}$ & $\mathrm{n} / \mathrm{a}$ & $n / a$ & $\mathrm{n} / \mathrm{a}$ & $\mathrm{n} / \mathrm{a}$ & 12.40 & $\mathrm{n} / \mathrm{a}$ & $\mathrm{n} / \mathrm{a}$ & $n / a$ & $\mathrm{n} / \mathrm{a}$ \\
\hline Suspended Solids & $w t \%$ & (ADS)BB\&TNX & $18.5^{\star \star \star}$ & $\mathrm{n} / \mathrm{a}$ & $\mathrm{n} / \mathrm{a}$ & $n / a$ & $\mathrm{n} / \mathrm{a}$ & $\mathrm{n} / \mathrm{a}$ & 19.2 & $\mathrm{n} / \mathrm{a}$ & $\mathrm{n} / \mathrm{a}$ \\
\hline Total Solids & $w t \%$ & (ADS)BB \& TNX & $18.5^{* \star \star}$ & $\mathrm{n} / \mathrm{a}$ & $\mathrm{n} / \mathrm{a}$ & $\mathrm{n} / \mathrm{a}$ & $\mathrm{n} / \mathrm{a}$ & $\mathrm{n} / \mathrm{a}$ & 19.2 & $\mathrm{n} / \mathrm{a}$ & $\mathrm{n} / \mathrm{a}$ \\
\hline Mean Particle Size by Volume & micron & (ADS)DB & $\mathrm{n} / \mathrm{a}$ & $n / a$ & $n / a$ & $\mathrm{n} / \mathrm{a}$ & $n / a$ & $\mathrm{n} / \mathrm{a}$ & $\mathrm{n} / \mathrm{a}$ & see below & $\mathrm{n} / \mathrm{a}$ \\
\hline Mean Particle Size by Number & micron & (ADS)DB & $\mathrm{n} / \mathrm{a}$ & $\mathrm{n} / \mathrm{a}$ & $\mathrm{n} / \mathrm{a}$ & $\mathrm{n} / \mathrm{a}$ & $\mathrm{n} / \mathrm{a}$ & $\mathrm{n} / \mathrm{a}$ & $\mathrm{n} / \mathrm{a}$ & 1.04 & $\mathrm{n} / \mathrm{a}$ \\
\hline Kinematic Viscosity & centistoke & (TNX)EH & $\mathrm{n} / \mathrm{a}$ & $\mathrm{n} / \mathrm{a}$ & $\mathrm{n} / \mathrm{a}$ & $n / a$ & $\mathrm{n} / \mathrm{a}$ & $\mathrm{n} / \mathrm{a}$ & $\mathrm{n} / \mathrm{a}$ & $\mathrm{n} / \mathrm{a}$ & $\mathrm{n} / \mathrm{a}$ \\
\hline 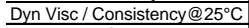 & $\mathrm{cP}$ & $(\mathrm{TNX}) \mathrm{EH}$ & $1.8^{*}$ & $\mathrm{n} / \mathrm{a}$ & $\mathrm{n} / \mathrm{a}$ & $\mathrm{n} / \mathrm{a}$ & $1.1^{*}$ & $\mathrm{n} / \mathrm{a}$ & $\mathrm{n} / \mathrm{a}$ & $\mathrm{n} / \mathrm{a}$ & $\mathrm{n} / \mathrm{a}$ \\
\hline 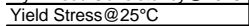 & $\mathrm{Pa}$ & (TNX)EH & $0.0^{*}$ & $\mathrm{n} / \mathrm{a}$ & $\mathrm{n} / \mathrm{a}$ & $\mathrm{n} / \mathrm{a}$ & $0.0^{*}$ & $\mathrm{n} / \mathrm{a}$ & $\mathrm{n} / \mathrm{a}$ & $\mathrm{n} / \mathrm{a}$ & $\mathrm{n} / \mathrm{a}$ \\
\hline Dyn Visc / Consistency@50 ${ }^{\circ} \mathrm{C}$ & $\mathrm{cP}$ & (TNX)EH & $0.8^{*}$ & $\mathrm{n} / \mathrm{a}$ & $\mathrm{n} / \mathrm{a}$ & $\mathrm{n} / \mathrm{a}$ & $0.6^{*}$ & $\mathrm{n} / \mathrm{a}$ & $\mathrm{n} / \mathrm{a}$ & $\mathrm{n} / \mathrm{a}$ & $\mathrm{n} / \mathrm{a}$ \\
\hline Yield Stress@50 & $\mathrm{Pa}$ & (TNX)EH & $0.0^{*}$ & $\mathrm{n} / \mathrm{a}$ & $\mathrm{n} / \mathrm{a}$ & $\mathrm{n} / \mathrm{a}$ & $0.0^{*}$ & $\mathrm{n} / \mathrm{a}$ & $\mathrm{n} / \mathrm{a}$ & $\mathrm{n} / \mathrm{a}$ & $\mathrm{n} / \mathrm{a}$ \\
\hline $\mathrm{pH}$ & none & (ADS)BB\&(TNX)EH & $7.52^{*}$ & $\mathrm{n} / \mathrm{a}$ & $\mathrm{n} / \mathrm{a}$ & $\mathrm{n} / \mathrm{a}$ & 7.53 & $\mathrm{n} / \mathrm{a}$ & $\mathrm{n} / \mathrm{a}$ & $\mathrm{n} / \mathrm{a}$ & $\mathrm{n} / \mathrm{a}$ \\
\hline Corrosivity & none & (F-Area)SB & $\mathrm{n} / \mathrm{a}$ & $\mathrm{n} / \mathrm{a}$ & $\begin{array}{ll}\mathrm{n} / \mathrm{a} \\
\end{array}$ & $\mathrm{n} / \mathrm{a}$ & $\mathrm{n} / \mathrm{a}$ & \begin{tabular}{|l|}
$\mathrm{n} / \mathrm{a}$ \\
\end{tabular} & $\mathrm{n} / \mathrm{a}$ & $\mathrm{n} / \mathrm{a}$ & $\mathrm{NC}^{*}$ \\
\hline $\begin{array}{l}\text { COLUMN-RELATED } \\
\text { COMMENTS }\end{array}$ & $\begin{array}{l}\text { *Units of } \\
\text { entries } \\
\text { unless } \\
\text { otherwise } \\
\text { noted }\end{array}$ & $\begin{array}{l}\text { Analyst Names } \\
\mathrm{DB}=\mathrm{D} \text {. Blankenship } \\
\mathrm{SB}=\text { Sarah Brown } \\
\mathrm{BB}=\text { Beverly Burch } \\
\mathrm{SB}=\text { Syderis Burkett } \\
\mathrm{JC}=\text { Joyce Cartledge }\end{array}$ & \begin{tabular}{|l|}
$*$ This sample \\
was remade \\
because of \\
being lost, \\
but used the \\
same recipe.
\end{tabular} & $\begin{array}{l}\text { Note: Not all } \\
\text { dissolutions n } \\
\text { because of th } \\
\text { instance, } 1 \text { \& } \\
\text { cible so only } \\
\text { value for Zr. }\end{array}$ & $\begin{array}{l}\text { the results for } \\
\text { methods can b } \\
\text { he way they ar } \\
2 \text { are done in } \\
\text { method } 3 \text { give } \\
\text { Usable values }\end{array}$ & $\begin{array}{l}\text { these three } \\
\text { e used } \\
\text { e done. For } \\
\text { a zinc cru- } \\
\text { s a usable } \\
\text { are shaded }\end{array}$ & $\begin{array}{l}\text { *supernate } \\
\text { viscosity } \\
\text { came from } \\
\text { the TNX } \\
\text { sample }\end{array}$ & $\begin{array}{l}\text { * this reading } \\
\text { may be } 5-10 \% \\
\text { high because } \\
\text { of contami- } \\
\text { nation from } \\
\text { a previous }\end{array}$ & & $\begin{array}{l}\text { "The volume } \\
\text { distribution } \\
\text { had two peaks } \\
\text { micons (\% total) } \\
1.65(28 \%) \\
11.74(72 \%)\end{array}$ & $\begin{array}{l}{ }^{*} \mathrm{NC}=\text { Non } \\
\text { Corrosive } \\
\text { Sample } \\
\text { Category } 1 \\
\text { Package } \\
\text { Group NC }\end{array}$ \\
\hline & & $\mathrm{BC}=$ B.S. Carter & ${ }^{* *} T N X$ liquid & like the one & shown heres & & & reading. Also & & & \\
\hline & & $\mathrm{EH}=$ Erick Hansen & density $=1.003$ & & & & & filtered & & & \\
\hline & & $\begin{array}{l}\text { FP }=\text { F. Pennebaker } \\
\text { RR }=\text { Robert Ray }\end{array}$ & $\begin{array}{l}* * * 1 \text { st sample } \\
\text { results, the }\end{array}$ & & & & & $\begin{array}{l}\text { sample may } \\
\text { have had }\end{array}$ & & & \\
\hline & & $\begin{array}{l}\mathrm{RR}=\text { Robert Ray } \\
\mathrm{TNX}=\mathrm{A} \text { lab at SRS }\end{array}$ & $\left|\begin{array}{l}\text { results, the } \\
\text { new sample }\end{array}\right|$ & & & & & $\begin{array}{l}\text { have had } \\
\text { solids }<5\end{array}$ & & & \\
\hline & & ADS $=$ Analytical & results are & & & & & microns that & & & \\
\hline & & $\begin{array}{l}\text { Development Sect. } \\
\text { at SRS }\end{array}$ & TS $=21.0 w t \%$ & & & & & contributed & & & \\
\hline OTHER COMMENTS & & & & & & & & & & & \\
\hline & & & & & & & & & & & \\
\hline $1=$ Dissolution - Sodium Perox & ide / uptake & e with Water & $4=C L-\operatorname{lon} S$ & Selective Emis & & $7=\mathrm{K}$ by $\mathrm{AA}$ & & $10=$ Total Sol & & $13=$ Specific Gra & avity \\
\hline 2 = Dissolution - Sodium Perox & ide / uptake & with Hydrochloric & $5=\mathrm{F}-\mathrm{Ion} \mathrm{Sel}$ & elective Emiss & & $8=$ TICTOC & & $11=$ Suspend & ded Solids & $14=\mathrm{pH}$ & \\
\hline $3=$ Dissolution with Aquaregen & t - $25 \%$ Nitri & ric Acid and $75 \% \mathrm{HCL}$ & $6=I C P-E S$ & & & $9=$ IC-Anions & & $12=$ Microtrac & c-particle size & & \\
\hline
\end{tabular}


Table A7. RPP-WTP Hanford Waste Simulant: Leached then washed HLW (AZ-101)

\begin{tabular}{|c|c|c|c|c|c|c|c|c|c|c|c|}
\hline \multirow{2}{*}{\multicolumn{2}{|c|}{ Most Recent Entry Date: 16-July-2001 }} & \multirow{2}{*}{ Slurry -------------->> } & & & & \multicolumn{6}{|c|}{ 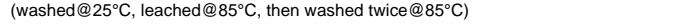 } \\
\hline & & & HLWleach/w & HLWleach/w & HLWleach/w & HLWleach/w & HLWleach/w & HLWleach/w & HLWleach/w & \multirow{5}{*}{$\begin{array}{c}\text { HLWleach/w } \\
\text { Prefix+8 } \\
300162952 \\
\text { slurry-20 wt\% } \\
15 \\
\text { MICROTRAC }\end{array}$} & \multirow{5}{*}{$\begin{array}{c}\text { HLWleach/w } \\
\text { Prefix+9 } \\
200155268 \\
\text { slurry-20 wt\% } \\
15 \\
\text { Corrosivity }\end{array}$} \\
\hline \multicolumn{2}{|c|}{ RPP Sample ID (Prefix = RPP-FILT139-H } & $\begin{array}{l}\text { LWleached/washed)->> } \\
\text { ADS Sample ID -->> }\end{array}$ & $\begin{array}{c}\text { Prefix }+1 \\
\text { None-TNX }\end{array}$ & $\begin{array}{c}\text { Prefix }+2 \\
300162946\end{array}$ & $\begin{array}{c}\text { Prefix }+3 \\
300162947\end{array}$ & $\begin{array}{l}\text { Prefix }+4 \\
300162948\end{array}$ & $\begin{array}{c}\text { Prefix }+5 \\
300162949\end{array}$ & $\begin{array}{l}\text { Prefix }+6 \\
300162950\end{array}$ & $\begin{array}{l}\text { Prefix }+7 \\
300162951\end{array}$ & & \\
\hline & & Type Sample ----->> & \multirow{2}{*}{\multicolumn{3}{|c|}{ slurry-20 wt $\%$ slurry-20 wt $\%$ slurry-20 wt $\%$}} & $\begin{array}{r}300162948 \\
\% \text { slurry-20 wt\% }\end{array}$ & $\begin{array}{l}300162949 \\
\% \text { supernatant }\end{array}$ & \multirow{2}{*}{$\begin{array}{l}300162950 \\
\text { supernatant } \\
15\end{array}$} & & & \\
\hline & & Sample Size $(\mathrm{mL})>>$ & & & & 15 & 15 & & 10 & & \\
\hline Measurement Made (NUMBER & IS ARE EXP & PLAINED BELOW) $>$ & Rheology & $1,4,5,9$ & $2,6,7$ & $3,6,7$ & $4,5,8,13,14$ & $6,7,9$ & 10,11 & & \\
\hline Item Measured & Units $^{*}$ & (Lab)Analyst & & & & & & & & & \\
\hline Density & $\mathrm{g} / \mathrm{mL}$ & (ADS)BB\&TNX(EH) & 1.178 & $\mathrm{n} / \mathrm{a}$ & $\mathrm{n} / \mathrm{a}$ & $\mathrm{n} / \mathrm{a}$ & 1.004 & $\mathrm{n} / \mathrm{a}$ & $\mathrm{n} / \mathrm{a}$ & $\mathrm{n} / \mathrm{a}$ & $\mathrm{n} / \mathrm{a}$ \\
\hline $\mathrm{Ag}$ & $\mathrm{ug} / \mathrm{mL}$ & (ADS)FP & $\mathrm{n} / \mathrm{a}$ & $\mathrm{n} / \mathrm{a}$ & $<150 \mathrm{ppm}$ & $<150 \mathrm{ppm}$ & $\mathrm{n} / \mathrm{a}$ & $<3$ & $\mathrm{n} / \mathrm{a}$ & $\mathrm{n} / \mathrm{a}$ & $\mathrm{n} / \mathrm{a}$ \\
\hline $\mathrm{Al}$ & $\mathrm{ug} / \mathrm{mL}$ & (ADS)FP & $\mathrm{n} / \mathrm{a}$ & $n / a$ & $11900 \mathrm{ppm}$ & $10000 \mathrm{ppm}$ & $n / a$ & 518 & $\mathrm{n} / \mathrm{a}$ & $\mathrm{n} / \mathrm{a}$ & $\mathrm{n} / \mathrm{a}$ \\
\hline $\mathrm{B}$ & $\mathrm{ug} / \mathrm{mL}$ & (ADS)FP & $\mathrm{n} / \mathrm{a}$ & $\mathrm{n} / \mathrm{a}$ & $249 \mathrm{ppm}$ & $236 \mathrm{ppm}$ & $\mathrm{n} / \mathrm{a}$ & $<2.1$ & $\mathrm{n} / \mathrm{a}$ & $\mathrm{n} / \mathrm{a}$ & $\mathrm{n} / \mathrm{a}$ \\
\hline $\mathrm{Ba}$ & $\mathrm{ug} / \mathrm{mL}$ & (ADS)FP & $\mathrm{n} / \mathrm{a}$ & $\mathrm{n} / \mathrm{a}$ & $42 \mathrm{ppm}$ & $<20 \mathrm{ppm}$ & $\mathrm{n} / \mathrm{a}$ & $<0.12$ & $\mathrm{n} / \mathrm{a}$ & $\mathrm{n} / \mathrm{a}$ & $\mathrm{n} / \mathrm{a}$ \\
\hline $\mathrm{Ca}$ & $\mathrm{ug} / \mathrm{mL}$ & (ADS)FP & $\mathrm{n} / \mathrm{a}$ & $\mathrm{n} / \mathrm{a}$ & $1070 \mathrm{ppm}$ & $333 \mathrm{ppm}$ & $\mathrm{n} / \mathrm{a}$ & $<0.4$ & $\mathrm{n} / \mathrm{a}$ & $\mathrm{n} / \mathrm{a}$ & $\mathrm{n} / \mathrm{a}$ \\
\hline $\mathrm{Ce}$ & $\mathrm{ug} / \mathrm{mL}$ & (ADS)FP & $\mathrm{n} / \mathrm{a}$ & $n / a$ & $<600 \mathrm{ppm}$ & $<600 \mathrm{ppm}$ & $\mathrm{n} / \mathrm{a}$ & $<7.7$ & $\mathrm{n} / \mathrm{a}$ & $n / a$ & $\mathrm{n} / \mathrm{a}$ \\
\hline $\mathrm{Cd}$ & $\mathrm{ug} / \mathrm{mL}$ & (ADS)FP & $\mathrm{n} / \mathrm{a}$ & $\mathrm{n} / \mathrm{a}$ & $<10 \mathrm{ppm}$ & $<10 \mathrm{ppm}$ & $n / a$ & $<0.14$ & $\mathrm{n} / \mathrm{a}$ & $n / a$ & $\mathrm{n} / \mathrm{a}$ \\
\hline$\overline{\mathrm{Cl} \text { (Chloride) [less accurate] }}$ & $\mathrm{ug} / \mathrm{mL}$ & (ADS)JC & $\mathrm{n} / \mathrm{a}$ & 18 & $\mathrm{n} / \mathrm{a}$ & $\mathrm{n} / \mathrm{a}$ & $n / a$ & $<0.2$ & $\mathrm{n} / \mathrm{a}$ & $\mathrm{n} / \mathrm{a}$ & $\mathrm{n} / \mathrm{a}$ \\
\hline Cl Sample & $\mathrm{ug} / \mathrm{mL}$ & (ADS)BC & $\mathrm{n} / \mathrm{a}$ & $<0.02$ & $\mathrm{n} / \mathrm{a}$ & $\mathrm{n} / \mathrm{a}$ & 24.2 & $\mathrm{n} / \mathrm{a}$ & $\mathrm{n} / \mathrm{a}$ & $n / a$ & $\mathrm{n} / \mathrm{a}$ \\
\hline Co & $\mathrm{ug} / \mathrm{mL}$ & (ADS)FP & $\mathrm{n} / \mathrm{a}$ & $\mathrm{n} / \mathrm{a}$ & $<25 \mathrm{ppm}$ & $<25 \mathrm{ppm}$ & $\mathrm{n} / \mathrm{a}$ & $<0.44$ & $\mathrm{n} / \mathrm{a}$ & $\mathrm{n} / \mathrm{a}$ & $\mathrm{n} / \mathrm{a}$ \\
\hline $\mathrm{Cr}$ & $\mathrm{ug} / \mathrm{mL}$ & (ADS)FP & $\mathrm{n} / \mathrm{a}$ & $\mathrm{n} / \mathrm{a}$ & $<25 \mathrm{ppm}$ & $<25 \mathrm{ppm}$ & $\mathrm{n} / \mathrm{a}$ & $<0.6$ & $\mathrm{n} / \mathrm{a}$ & $\mathrm{n} / \mathrm{a}$ & $\mathrm{n} / \mathrm{a}$ \\
\hline$\overline{\mathrm{Cu}}$ & $\mathrm{ug} / \mathrm{mL}$ & (ADS)FP & $\mathrm{n} / \mathrm{a}$ & $\mathrm{n} / \mathrm{a}$ & $<25 \mathrm{ppm}$ & $<25 \mathrm{ppm}$ & $\mathrm{n} / \mathrm{a}$ & $<0.5$ & $\mathrm{n} / \mathrm{a}$ & $n / a$ & $\mathrm{n} / \mathrm{a}$ \\
\hline$\overline{F \text { (Fluoride) [less accurate] }}$ & $\mathrm{ug} / \mathrm{mL}$ & $($ ADS $) J C$ & $\mathrm{n} / \mathrm{a}$ & $<0.02$ & $\mathrm{n} / \mathrm{a}$ & $\mathrm{n} / \mathrm{a}$ & $\mathrm{n} / \mathrm{a}$ & $<0.2$ & $\mathrm{n} / \mathrm{a}$ & $\mathrm{n} / \mathrm{a}$ & $n / a$ \\
\hline F Sample (more accurate resul & $\mathrm{ug} / \mathrm{mL}$ & $(\mathrm{ADS}) \mathrm{BC}$ & $\mathrm{n} / \mathrm{a}$ & $<0.02$ & $\mathrm{n} / \mathrm{a}$ & $\mathrm{n} / \mathrm{a}$ & 10.82 & $\mathrm{n} / \mathrm{a}$ & $\mathrm{n} / \mathrm{a}$ & $n / a$ & $n / a$ \\
\hline $\mathrm{Fe}$ & $\mathrm{ug} / \mathrm{mL}$ & (ADS)FP & $\mathrm{n} / \mathrm{a}$ & $\mathrm{n} / \mathrm{a}$ & $67300 \mathrm{ppm}$ & $68100 \mathrm{ppm}$ & $\mathrm{n} / \mathrm{a}$ & $<0.44$ & $\mathrm{n} / \mathrm{a}$ & $\mathrm{n} / \mathrm{a}$ & $\mathrm{n} / \mathrm{a}$ \\
\hline HCOO (Formate) & $\mathrm{ug} / \mathrm{mL}$ & (ADS)RR\&JC & $\mathrm{n} / \mathrm{a}$ & $<1$ & $\mathrm{n} / \mathrm{a}$ & $\mathrm{n} / \mathrm{a}$ & $\mathrm{n} / \mathrm{a}$ & $<1$ & $\mathrm{n} / \mathrm{a}$ & $n / a$ & $\mathrm{n} / \mathrm{a}$ \\
\hline $\mathrm{K}$ & $\mathrm{ug} / \mathrm{mL}$ & (ADS)FP & $\mathrm{n} / \mathrm{a}$ & $\mathrm{n} / \mathrm{a}$ & $<250 \mathrm{ppm}$ & $<250 \mathrm{ppm}$ & $\mathrm{n} / \mathrm{a}$ & 13 & $\mathrm{n} / \mathrm{a}$ & $n / a$ & $\mathrm{n} / \mathrm{a}$ \\
\hline $\mathrm{K}(\mathrm{AA})$ & $\mathrm{ug} / \mathrm{mL}$ & (ADS)SB & $\mathrm{n} / \mathrm{a}$ & $\mathrm{n} / \mathrm{a}$ & $0.017 \mathrm{wt} \%$ & $0.0155 \mathrm{wt} \%$ & $n / a$ & 278.0025 & $\mathrm{n} / \mathrm{a}$ & $n / a$ & $n / a$ \\
\hline La & $\mathrm{ug} / \mathrm{mL}$ & (ADS)FP & $\mathrm{n} / \mathrm{a}$ & $\mathrm{n} / \mathrm{a}$ & $<350 \mathrm{ppm}$ & $<350 \mathrm{ppm}$ & $\mathrm{n} / \mathrm{a}$ & $<7$ & $\mathrm{n} / \mathrm{a}$ & $\mathrm{n} / \mathrm{a}$ & $n / a$ \\
\hline $\mathrm{Li}$ & $\mathrm{ug} / \mathrm{mL}$ & (ADS)FP & $\mathrm{n} / \mathrm{a}$ & $n / a$ & $<50 \mathrm{ppm}$ & $<50 \mathrm{ppm}$ & $n / a$ & $<1$ & $\mathrm{n} / \mathrm{a}$ & $n / a$ & $n / a$ \\
\hline$\overline{\mathrm{Mg}}$ & $\mathrm{ug} / \mathrm{mL}$ & (ADS)FP & $n / a$ & $n / a$ & $477 \mathrm{ppm}$ & $420 \mathrm{ppm}$ & $n / a$ & $<0.84$ & $n / a$ & $n / a$ & $n / a$ \\
\hline$\overline{\mathrm{Mn}}$ & $\mathrm{ug} / \mathrm{mL}$ & (ADS)FP & $\mathrm{n} / \mathrm{a}$ & $n / a$ & $239 \mathrm{ppm}$ & $246 \mathrm{ppm}$ & $n / a$ & $<0.09$ & $\mathrm{n} / \mathrm{a}$ & $n / a$ & $n / a$ \\
\hline$\overline{M o}$ & $\mathrm{ug} / \mathrm{mL}$ & (ADS)FP & $\mathrm{n} / \mathrm{a}$ & $n / a$ & $<50 \mathrm{ppm}$ & $<50 \mathrm{ppm}$ & $n / a$ & $<1$ & $n / a$ & $n / a$ & $n / a$ \\
\hline $\mathrm{Na}$ & $\mathrm{ug} / \mathrm{mL}$ & (ADS)FP & $n / a$ & $n / a$ & $\mathrm{n} / \mathrm{a}$ & $3840 \mathrm{ppm}$ & $n / a$ & 2750 & $n / a$ & $n / a$ & $n / a$ \\
\hline$\overline{\mathrm{Nd}}$ & $\mathrm{ug} / \mathrm{mL}$ & (ADS)FP & $n / a$ & $n / a$ & $\mathrm{n} / \mathrm{a}$ & $\mathrm{n} / \mathrm{a}$ & $n / a$ & $\mathrm{n} / \mathrm{a}$ & $n / a$ & $n / a$ & $n / a$ \\
\hline $\mathrm{Ni}$ & $\mathrm{ug} / \mathrm{mL}$ & (ADS)FP & $n / a$ & $\mathrm{n} / \mathrm{a}$ & $<30 \mathrm{ppm}$ & $<30 \mathrm{ppm}$ & $\mathrm{n} / \mathrm{a}$ & $<0.62$ & $\mathrm{n} / \mathrm{a}$ & $n / a$ & $n / a$ \\
\hline NO2 (Nitrite) & $\mathrm{ug} / \mathrm{mL}$ & (ADS)RR\&JC & $\mathrm{n} / \mathrm{a}$ & $<1$ & $\mathrm{n} / \mathrm{a}$ & $\mathrm{n} / \mathrm{a}$ & $n / a$ & $<1$ & $\mathrm{n} / \mathrm{a}$ & $\mathrm{n} / \mathrm{a}$ & $n / a$ \\
\hline NO3 (Nitrate) & $\mathrm{ug} / \mathrm{mL}$ & (ADS)RR\&JC & $n / a$ & 2 & $n / a$ & $\mathrm{n} / \mathrm{a}$ & $n / a$ & 25 & $\mathrm{n} / \mathrm{a}$ & $n / a$ & $n / a$ \\
\hline C2O4 (Oxalate) & $\mathrm{ug} / \mathrm{mL}$ & (ADS)RR\&JC & $n / a$ & $<1$ & $\mathrm{n} / \mathrm{a}$ & $\mathrm{n} / \mathrm{a}$ & $n / a$ & $<1$ & $\mathrm{n} / \mathrm{a}$ & $n / a$ & $n / a$ \\
\hline $\mathrm{P}$ & $\mathrm{ug} / \mathrm{mL}$ & (ADS)FP & $n / a$ & $\mathrm{n} / \mathrm{a}$ & $<400 \mathrm{ppm}$ & $<400 \mathrm{ppm}$ & $n / a$ & $<6.8$ & $\mathrm{n} / \mathrm{a}$ & $n / a$ & $n / a$ \\
\hline PO4 (Phosphate) & $\mathrm{ug} / \mathrm{mL}$ & (ADS)RR\&JC & $n / a$ & $<1$ & $\mathrm{n} / \mathrm{a}$ & $\mathrm{n} / \mathrm{a}$ & $n / a$ & 1 & $\mathrm{n} / \mathrm{a}$ & $n / a$ & $n / a$ \\
\hline $\mathrm{Pb}$ & $\mathrm{ug} / \mathrm{mL}$ & (ADS)FP & $n / a$ & $n / a$ & $<400 \mathrm{ppm}$ & $<400 \mathrm{ppm}$ & $n / a$ & $<6.9$ & $\mathrm{n} / \mathrm{a}$ & $n / a$ & $n / a$ \\
\hline $\mathrm{s}$ & $\mathrm{ug} / \mathrm{mL}$ & (ADS)FP & $n / a$ & $n / a$ & $<250 \mathrm{ppm}$ & $<250 \mathrm{ppm}$ & $\mathrm{n} / \mathrm{a}$ & $<5$ & $\mathrm{n} / \mathrm{a}$ & $\mathrm{n} / \mathrm{a}$ & $\mathrm{n} / \mathrm{a}$ \\
\hline Si & $\mathrm{ug} / \mathrm{mL}$ & (ADS)FP & $\mathrm{n} / \mathrm{a}$ & $\mathrm{n} / \mathrm{a}$ & $7820 \mathrm{ppm}$ & $1450 \mathrm{ppm}$ & $n / a$ & $<1.3$ & $\mathrm{n} / \mathrm{a}$ & $n / a$ & $n / a$ \\
\hline Sn & $\mathrm{ug} / \mathrm{mL}$ & (ADS)FP & $\mathrm{n} / \mathrm{a}$ & $\mathrm{n} / \mathrm{a}$ & $<300 \mathrm{ppm}$ & $<300 \mathrm{ppm}$ & $\mathrm{n} / \mathrm{a}$ & $<2.6$ & $\mathrm{n} / \mathrm{a}$ & $\mathrm{n} / \mathrm{a}$ & $\mathrm{n} / \mathrm{a}$ \\
\hline SO4 (Sulfate) & $\mathrm{ug} / \mathrm{mL}$ & (ADS)RR\&JC & $\mathrm{n} / \mathrm{a}$ & $<0.5$ & $\mathrm{n} / \mathrm{a}$ & $\mathrm{n} / \mathrm{a}$ & $n / a$ & 3 & $\mathrm{n} / \mathrm{a}$ & $\mathrm{n} / \mathrm{a}$ & $\mathrm{n} / \mathrm{a}$ \\
\hline $\mathrm{Sr}$ & $\mathrm{ug} / \mathrm{mL}$ & (ADS)FP & $\mathrm{n} / \mathrm{a}$ & $\mathrm{n} / \mathrm{a}$ & $272 \mathrm{ppm}$ & $258 \mathrm{ppm}$ & $\mathrm{n} / \mathrm{a}$ & $<0.5$ & $\mathrm{n} / \mathrm{a}$ & $\mathrm{n} / \mathrm{a}$ & $n / a$ \\
\hline$\overline{\mathrm{Ti}}$ & $\mathrm{ug} / \mathrm{mL}$ & (ADS)FP & $\mathrm{n} / \mathrm{a}$ & $\mathrm{n} / \mathrm{a}$ & $<70 \mathrm{ppm}$ & $<70 \mathrm{ppm}$ & $\mathrm{n} / \mathrm{a}$ & $<1.4$ & $\mathrm{n} / \mathrm{a}$ & $\mathrm{n} / \mathrm{a}$ & $\mathrm{n} / \mathrm{a}$ \\
\hline$\overline{\mathrm{V}}$ & $\mathrm{ug} / \mathrm{mL}$ & (ADS)FP & $\mathrm{n} / \mathrm{a}$ & $\mathrm{n} / \mathrm{a}$ & $470 \mathrm{ppm}$ & $473 \mathrm{ppm}$ & $\mathrm{n} / \mathrm{a}$ & $<1.3$ & $\mathrm{n} / \mathrm{a}$ & $\mathrm{n} / \mathrm{a}$ & $\mathrm{n} / \mathrm{a}$ \\
\hline $\bar{W}$ & $\mathrm{ug} / \mathrm{mL}$ & (ADS)FP & $\mathrm{n} / \mathrm{a}$ & $\mathrm{n} / \mathrm{a}$ & $716 \mathrm{ppm}^{*}$ & $1048 \mathrm{ppm}^{*}$ & $\mathrm{n} / \mathrm{a}$ & $651^{*}$ & $\mathrm{n} / \mathrm{a}$ & $\mathrm{n} / \mathrm{a}$ & $\mathrm{n} / \mathrm{a}$ \\
\hline$\overline{Z n}$ & $\mathrm{ug} / \mathrm{mL}$ & (ADS)FP & $\mathrm{n} / \mathrm{a}$ & $\mathrm{n} / \mathrm{a}$ & $<200 \mathrm{ppm}$ & $<200 \mathrm{ppm}$ & $\mathrm{n} / \mathrm{a}$ & $<3.7$ & $\mathrm{n} / \mathrm{a}$ & $\mathrm{n} / \mathrm{a}$ & $\mathrm{n} / \mathrm{a}$ \\
\hline$\underline{\mathrm{Zr}}$ & $\mathrm{ug} / \mathrm{mL}$ & (ADS)FP & $\mathrm{n} / \mathrm{a}$ & $\mathrm{n} / \mathrm{a}$ & $\mathrm{n} / \mathrm{a}$ & $13200 \mathrm{ppm}$ & $\mathrm{n} / \mathrm{a}$ & $<0.48$ & $\mathrm{n} / \mathrm{a}$ & $\mathrm{n} / \mathrm{a}$ & $\mathrm{n} / \mathrm{a}$ \\
\hline Total Organic Carbon & $\mathrm{ug} / \mathrm{mL}$ & $(\mathrm{ADS}) \mathrm{BC}$ & $\mathrm{n} / \mathrm{a}$ & $\mathrm{n} / \mathrm{a}$ & $\mathrm{n} / \mathrm{a}$ & $\mathrm{n} / \mathrm{a}$ & 538.00 & $\mathrm{n} / \mathrm{a}$ & $\mathrm{n} / \mathrm{a}$ & $\mathrm{n} / \mathrm{a}$ & $\mathrm{n} / \mathrm{a}$ \\
\hline Total Inorganic Carbon & $\mathrm{ug} / \mathrm{mL}$ & $(\mathrm{ADS}) \mathrm{BC}$ & $\mathrm{n} / \mathrm{a}$ & $\mathrm{n} / \mathrm{a}$ & $\mathrm{n} / \mathrm{a}$ & $\mathrm{n} / \mathrm{a}$ & $<100$ & $\mathrm{n} / \mathrm{a}$ & \begin{tabular}{|l}
$\mathrm{n} / \mathrm{a}$ \\
\end{tabular} & $\mathrm{n} / \mathrm{a}$ & $\mathrm{n} / \mathrm{a}$ \\
\hline Suspended Solids & wt\% & (ADS)BB\&TNX & 20.4 & $\mathrm{n} / \mathrm{a}$ & $\mathrm{n} / \mathrm{a}$ & $\mathrm{n} / \mathrm{a}$ & $\mathrm{n} / \mathrm{a}$ & $\mathrm{n} / \mathrm{a}$ & $16.0[\mathrm{see} \mathrm{(1)]}$ & $\mathrm{n} / \mathrm{a}$ & $\mathrm{n} / \mathrm{a}$ \\
\hline Total Solids & $\mathrm{wt} \%$ & (ADS)BB \& TNX & 20.9 & $\mathrm{n} / \mathrm{a}$ & $\mathrm{n} / \mathrm{a}$ & $\mathrm{n} / \mathrm{a}$ & $n / a$ & $\mathrm{n} / \mathrm{a}$ & $16.0[\mathrm{see}(1)]$ & $\mathrm{n} / \mathrm{a}$ & $n / a$ \\
\hline Mean Particle Size by Volume & micron & (ADS)DB & $\mathrm{n} / \mathrm{a}$ & $\mathrm{n} / \mathrm{a}$ & $\mathrm{n} / \mathrm{a}$ & $\mathrm{n} / \mathrm{a}$ & $\mathrm{n} / \mathrm{a}$ & $\mathrm{n} / \mathrm{a}$ & \begin{tabular}{|l|}
$\mathrm{n} / \mathrm{a}$ \\
\end{tabular} & see below & $\mathrm{n} / \mathrm{a}$ \\
\hline Mean Particle Size by Number & micron & $($ ADS)DB & $\mathrm{n} / \mathrm{a}$ & $\mathrm{n} / \mathrm{a}$ & $n / a$ & $\mathrm{n} / \mathrm{a}$ & n/a & $\mathrm{n} / \mathrm{a}$ & $\mathrm{n} / \mathrm{a}$ & 1.01 & $n / a$ \\
\hline Kinematic Viscosity & $\begin{array}{l}\text { centistoke } \\
\end{array}$ & (TNX)EH & $\mathrm{n} / \mathrm{a}$ & $\mathrm{n} / \mathrm{a}$ & $\mathrm{n} / \mathrm{a}$ & $\mathrm{n} / \mathrm{a}$ & $\mathrm{n} / \mathrm{a}$ & $\mathrm{n} / \mathrm{a}$ & $\mathrm{n} / \mathrm{a}$ & $\mathrm{n} / \mathrm{a}$ & $\mathrm{n} / \mathrm{a}$ \\
\hline 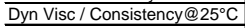 & $\mathrm{cP}$ & (TNX)EH & 1.6 & $\mathrm{n} / \mathrm{a}$ & $\mathrm{n} / \mathrm{a}$ & $\mathrm{n} / \mathrm{a}$ & $1.0^{\star}$ & $\mathrm{n} / \mathrm{a}$ & $\mathrm{n} / \mathrm{a}$ & $\mathrm{n} / \mathrm{a}$ & $\mathrm{n} / \mathrm{a}$ \\
\hline 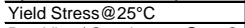 & $\mathrm{Pa}$ & $(\mathrm{TNX}) \mathrm{EH}$ & 0.0 & $\mathrm{n} / \mathrm{a}$ & $\mathrm{n} / \mathrm{a}$ & $\mathrm{n} / \mathrm{a}$ & $0.0^{*}$ & $\mathrm{n} / \mathrm{a}$ & $\mathrm{n} / \mathrm{a}$ & $\mathrm{n} / \mathrm{a}$ & $\mathrm{n} / \mathrm{a}$ \\
\hline Dyn Visc / Consistency@50 $\mathrm{C}$ & $\mathrm{CP}$ & (TNX)EH & 0.8 & $\mathrm{n} / \mathrm{a}$ & $\mathrm{n} / \mathrm{a}$ & $\mathrm{n} / \mathrm{a}$ & $0.6^{*}$ & $\mathrm{n} / \mathrm{a}$ & $\mathrm{n} / \mathrm{a}$ & $\mathrm{n} / \mathrm{a}$ & $\mathrm{n} / \mathrm{a}$ \\
\hline Yield Stress@50 & $\mathrm{Pa}$ & (TNX)EH & 0.0 & $\mathrm{n} / \mathrm{a}$ & $\mathrm{n} / \mathrm{a}$ & $\mathrm{n} / \mathrm{a}$ & $0.0^{*}$ & $\mathrm{n} / \mathrm{a}$ & $\mathrm{n} / \mathrm{a}$ & $\mathrm{n} / \mathrm{a}$ & $\mathrm{n} / \mathrm{a}$ \\
\hline $\mathrm{pH}$ & none & (ADS)BB\&(TNX)EH & 12.36 & $\mathrm{n} / \mathrm{a}$ & $\mathrm{n} / \mathrm{a}$ & $\mathrm{n} / \mathrm{a}$ & 12.39 & $\mathrm{n} / \mathrm{a}$ & $\mathrm{n} / \mathrm{a}$ & $\mathrm{n} / \mathrm{a}$ & $\mathrm{n} / \mathrm{a}$ \\
\hline Corrosivity & none & (F-Area)SB & $\mathrm{n} / \mathrm{a}$ & $\mathrm{n} / \mathrm{a}$ & $\mathrm{n} / \mathrm{a}$ & $\mathrm{n} / \mathrm{a}$ & $\mathrm{n} / \mathrm{a}$ & $\mathrm{n} / \mathrm{a}$ & $\mathrm{n} / \mathrm{a}$ & $\mathrm{n} / \mathrm{a}$ & \begin{tabular}{|l|}
$\mathrm{NC}^{*}$ \\
\end{tabular} \\
\hline $\begin{array}{l}\text { COLUMN-RELATED } \\
\text { COMMENTS }\end{array}$ & $\begin{array}{l}\text { "Units of } \\
\text { entries } \\
\text { unless } \\
\text { otherwise } \\
\text { noted }\end{array}$ & $\begin{array}{l}\text { Analyst Names } \\
\mathrm{DB}=\text { Don Blankenshi } \\
\mathrm{SB}=\text { Sarah Brown } \\
\mathrm{BB}=\text { Beverly Burch } \\
\mathrm{SB}=\text { Syderis Burkett } \\
\mathrm{JC}=\text { Joyce Cartledge }\end{array}$ & \begin{tabular}{|l|} 
*density of \\
supernate as \\
measured by \\
TNX = 1.007 \\
\end{tabular} & $\begin{array}{l}\text { Note: Not all } \\
\text { dissolutions } n \\
\text { because of th } \\
\text { instance, } 1 \text { \& } \\
\text { cible so only } \\
\text { value for Zr. L }\end{array}$ & $\begin{array}{l}\text { the results for } \\
\text { nethods can b } \\
\text { ne way they are } \\
2 \text { are done in } \\
\text { method } 3 \text { gives } \\
\text { Usable values }\end{array}$ & $\begin{array}{l}\text { these three } \\
\text { e used } \\
\text { done. For } \\
\text { a zinc cru- } \\
\text { s a usable } \\
\text { are shaded }\end{array}$ & \begin{tabular}{|l} 
*supernate \\
viscosity \\
came from \\
the TNX \\
sample
\end{tabular} & $\begin{array}{l}{ }^{*} \text { The test for } \\
\text { Tungsten } \\
\text { can measure } \\
\text { solids that } \\
\text { were in the } \\
\text { supernatant. }\end{array}$ & & $\begin{array}{l}\text { *The volume } \\
\text { distribution } \\
\text { had three peaks } \\
\text { micons (\% total) } \\
1.59(31 \%) \\
5.05(24 \%)\end{array}$ & $\begin{array}{l}{ }^{*} \mathrm{NC}=\text { Non } \\
\text { Corrosive } \\
\text { Sample } \\
\text { Category } 2 \\
\text { Package } \\
\text { Group NC }\end{array}$ \\
\hline & & $\mathrm{BC}=$ B.S. Carter & & like the one & shown here> & & & Filtering may & & $16.72(45 \%)$ & \\
\hline & & $\begin{array}{l}\mathrm{EH}=\text { Erick Hansen } \\
\mathrm{FP}=\text { Frank Pennebak } \\
\text { RR = Robert Ray } \\
\mathrm{TNX}=\text { A laboratory at } \\
\mathrm{ADS}=\text { Analytical Deve }\end{array}$ & $\begin{array}{l}\text { aker } \\
\text { at SRS } \\
\text { velopment Sect }\end{array}$ & tion at SRS & $\begin{array}{l}\text { * these two sa } \\
\text { be } 10-15 \% \text { hi } \\
\text { of being conta } \\
\text { from previous }\end{array}$ & $\begin{array}{l}\text { amples may }{ }^{*} \\
\text { gh because } \\
\text { aminated } \\
W \text { readings }\end{array}$ & & $\begin{array}{l}\text { leave solids } \\
<5 \text { microns } \\
\text { in solution } \\
\text { which is the } \\
\text { majority of } \\
\text { the particle } \\
\text { sizes. }\end{array}$ & & & \\
\hline
\end{tabular}

\section{Analysis Nomenclature}

= Dissolution - Sodium Peroxide / uptake with Water $\quad 4=\mathrm{CL}-$ Ion Selective Emission

$2=$ Dissolution - Sodium Peroxide $/$ uptake with Hydrochloric $\quad 5=\mathrm{F}$ - Ion Selective Emission

$8=$ TICTOC

$10=$ Total Solids $\quad 13=$ Specific Gravity

$3=$ Dissolution with Aquaregent $-25 \%$ Nitric Acid and $75 \% \mathrm{HCL} \quad 6=$ ICP-ES

$12=$ Microtrac - particle size

(1) This solids measurement was done twice. It is assumed that the method of drawing the sample caused the lower solids value than the TNX values of $20 \mathrm{wt} \%$. The sample method was to shake the container vigorously than pour into a $15 \mathrm{ml}$ bottle. The measurement was done a third and fourth time by the shake method and by drawing a sample with a Caliwasa from a well
mixed slurry. However, this time originally taken, which gave the $16 \mathrm{wt} \%$ result, care was not taken to make sure it was well mixed while pouring into the sample containers. However, the dilemma is that all of the slurry samples, which were sent to White Rock Engineering forthe erosion tests to obtain SAR numbers, were done at the same time the $16 \mathrm{wt} \%$ samples were taken. This means the slurry samples could of have a solids loading from between $16 \mathrm{wt} \%$ and $20 \mathrm{wt} \%$. For reporting purposes an insoluble solids concentration of $18 \mathrm{wt} \%$ will be used. 


\section{APPENDIX B}

\section{White Rock Engineering Services Slurry Abrasivity Number Report}

The following appendix of thirty-one pages is the WRES SAR Number report in its entirety as it was received by WSRC on 1/11/2002. It does not include information on how the data were obtained; that is done at the beginning of this report. Besides the data for the seven slurries tested, it includes a before and after standard sand test to indicate that the test apparatus was working within ASTM standards. In fact, the initial standard test was observed by a WSRC QA inspector to verify that the procedure used followed the appropriate ASTM standard. WRES did meet at least the minimum qualifications to produced qualified data.

The report format is as follows:

- Vendor pages 1 to 4 give an overall summary of the data within.

- Vendor pages 5 to 9 give the results of standard sand tests to show that the test device could reproduce published sand abrasivity numbers and meet the standard ASTM G75-2001.

- Vendor pages 10 to 31 give the results of all the SAR tests. First, micro-photographs are given of the slurry solids and four metal specimens: two 304L and two 316L stainless steel. These are followed by one page which averages the two 304L test results and by one page which averages the two 316L test results. The exception is vendor page 23 (test S-1033) which shows the original two 316L tests. Those tests were discarded and repeated (test S1033R) because the result of the second test of S-1033 was inconsistent with the first test due to solids clumping - according to the vendor. However, the two 316L tests shown in test S1033R gave the same results as the first of the two tests in test S-1033, which confirms that the second test was a bad datum point. 


\title{
Miller Number and SAR Number Determination by ASTM G75-2001
}

\author{
For
}

\section{Westinghouse Savannah River - AB80166N}

Westinghouse Savanna River submitted seven (7) Slurry Samples and two (2) Wear Specimen Materials (304L and 316L) to conduct the ASTM G75-2001 Slurry Abrasion Response Test (SAR Number). Slurry Batches and Wear Specimens were identified by a Westinghouse Test Number. The 304L and 316L Wear Specimens were received with a slight amount of surface corrosion. The corrosion was removed by sanding with 120 grit sand paper and finished with 320 grit sand paper. Slurry as received at a $20 \%$ by mass solids concentration was used. Tests were conducted at either 25 or 85 degrees Celsius within a \pm 5 degrees Celsius temperature range. As part of the test program a Standard AFS 50-70 Test Sand Miller Number was conducted at the beginning and end of the SAR Test Sequence as a control of the test procedure. To comply with a Westinghouse Savannah River Company Quality Assurance requirement, the initial Standard Test was done under the observation of a Quality Assurance Inspector, John J. Connelly, during an onsite (Dallas, Texas) visit on January 4-6, 2001. The QA inspector found (WSRC Document No. 2001-SUR-11-0009, Nov. 2001) the actual test procedure used faithfully followed the American Society for Testing \& Materials Procedure G75-2001. A Calcium Hydroxide corrosion inhibited slurry test was also performed as part of the standard Miller Number Test Procedure.

\begin{tabular}{|c|c|c|c|c|c|c|c|c|}
\hline & Test & Specimen & Slurry & Temp & \multicolumn{2}{|c|}{$\mathbf{p H}$} & \multicolumn{2}{|c|}{ SAR/Miller Number } \\
\hline & & & & ${ }^{\circ} \mathbf{C}$ & Low & High & Abrasivity & Attrition \% \\
\hline & M-1023 & $27 \%$ Chrome & AFS 50-70 Test Sand & 25 & 6.7 & 7.5 & 129 & -8 \\
\hline & M-1023I & $27 \%$ Chrome & $\mathrm{Ca}(\mathrm{OH})_{2}$ Inhibited & 25 & 7.5 & 12.6 & 93 & -11 \\
\hline 1 & S-1024 & 304L 1A \& 1B & HLW & 25 & 13.2 & 13.3 & 156 & -9 \\
\hline 1 & S-1025 & 316L 1A \& 1B & HLW & 25 & 13.2 & 13.2 & 151 & -15 \\
\hline 2 & S-1026 & 304L 2A \& 2B & HLWwSBS & 25 & 12.8 & 12.9 & 163 & 2 \\
\hline 2 & S-1027 & $316 L 2 A \& 2 B$ & HLWwSBS & 25 & 12.8 & 12.9 & 221 & 6 \\
\hline 3 & S-1028 & 304L 3A \& 3B & Sr/Tru & 25 & NA & NA & 10 & -14 \\
\hline
\end{tabular}


RPP-WTP Slurry Wear Evaluation: Slurry Abrasivity

WSRC-TR-2002-00062, Rev. 0

SRT-RPP-2002-00022, Rev. 0

\begin{tabular}{|c|c|c|c|c|c|c|c|c|}
\hline & Test & Specimen & Slurry & Temp & \multicolumn{2}{|c|}{ pH } & \multicolumn{2}{|c|}{ SAR/Miller Number } \\
\hline & & & & ${ }^{\circ} \mathbf{C}$ & Low & High & Abrasivity & Attrition \% \\
\hline 3 & S-1029 & 316L 3A \& 3B & Sr/Tru & 25 & NA & NA & 9 & 4 \\
\hline 4 & S-1030 & 304L 4A \& 4B & HLW leached & 85 & 11.7 & 11.8 & 103 & -3 \\
\hline 4 & S-1031 & 316L 4A \& 4B & HLW leached & 85 & 11.7 & 11.8 & 99 & -4 \\
\hline 5 & S-1032 & 304L 5A \& 5B & HLWwSBS leached & 25 & 12.4 & 12.6 & 206 & -4 \\
\hline 5 & S-1033 & 316L 5A \& 5B & HLWwSBS leached & 25 & 12.4 & 12.6 & 384 & -4 \\
\hline 5 & S-1033R & 316L 5A \& 5B & HLWwSBS leached & 25 & 13.4 & 13.7 & 280 & 4 \\
\hline 6 & S-1041 & $304 L 6 A \& 6 B$ & HLW Washed & 25 & 7.7 & 8.2 & 138 & -11 \\
\hline 6 & S-1042 & $316 L$ 6A \& $6 B$ & HLW Washed & 25 & 7.5 & 8.2 & 92 & -25 \\
\hline 7 & S-1043 & 304L 7A \& 7B & HLW Wash/Leach & 85 & 11.0 & 11.3 & 9 & -5 \\
\hline 7 & S-1044 & 316L 7A \& 7B & HLW Wash/Leach & 85 & 11.0 & 11.3 & 13 & -15 \\
\hline & M-1034 & 27\% Chrome & AFS 50-70 Test Sand & 25 & 8.5 & 8.9 & 117 & -6 \\
\hline & M-1034I & $27 \%$ Chrome & $\mathrm{Ca}(\mathrm{OH})_{2}$ Inhibited & 25 & 12.4 & 12.8 & 76 & -3 \\
\hline
\end{tabular}

Table 3 - Test Results Summary 
WSRC-TR-2002-00062, Rev. 0

SRT-RPP-2002-00022, Rev. 0

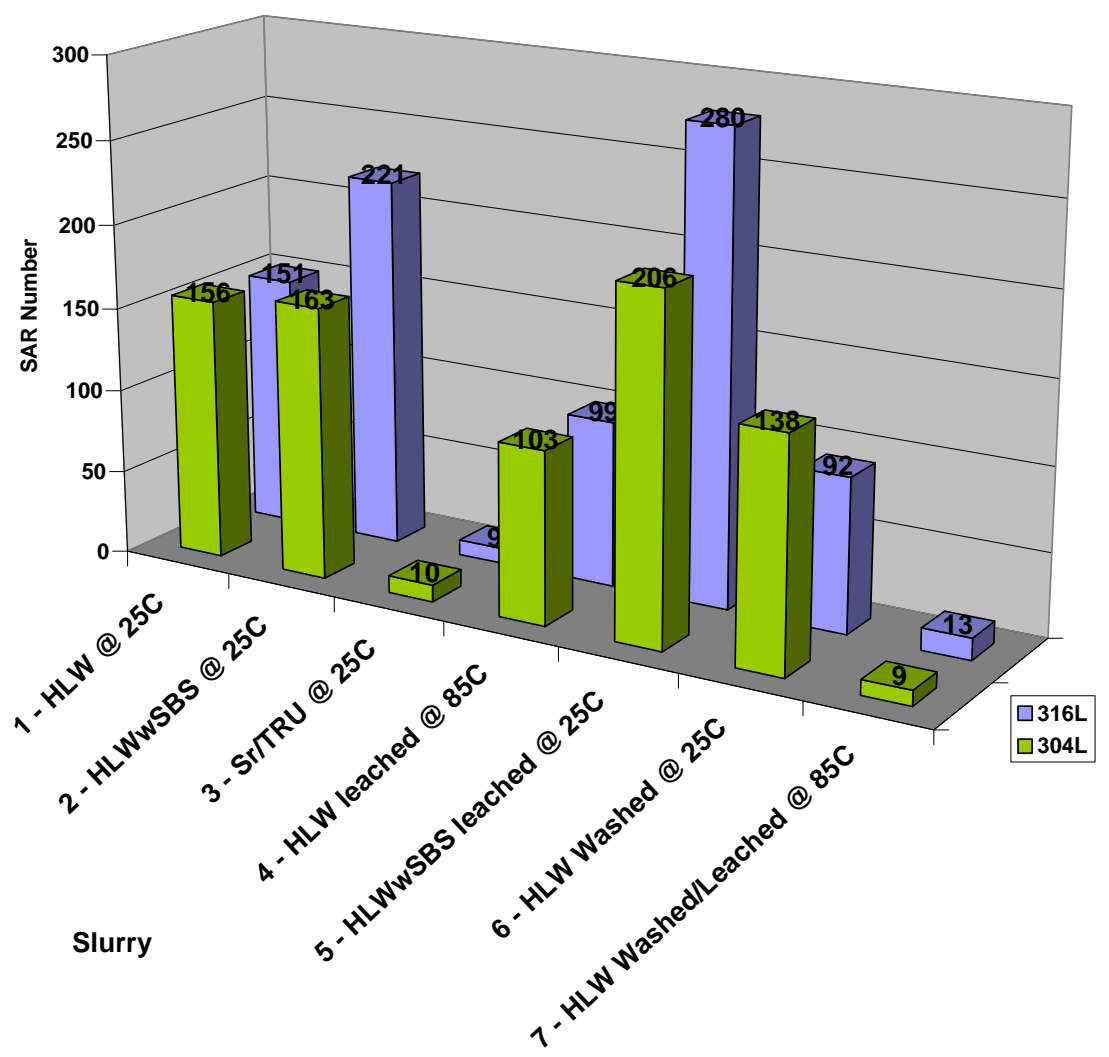

Figure 1 - Test Results Summary

The 304L Stainless Steel was nearly equal to or better from abrasivity (corrosion and erosion) resistance than 316L Stainless Steel in all cases except the HLW Washed material. Test results variability is generally in the range of $\pm 5 \%$ when Miller and SAR Numbers are above a value of 50. Variability of test results increases significantly as Miller and SAR Numbers fall below 15 because of low mass loss of the wear specimen and the magnitude of measurement error.

A significant range of SAR Numbers were obtained from the different slurries. The SAR Numbers ranged from 9 to 280. Most of the slurries tested had a high to severe abrasivity. Abrasivity ranking of the Miller Number and SAR Number result is considered low when the value is below 50, moderate between 50 and 100, high between 100 and 200, and severe when above 200. The ranking of test results between two wear specimens is questionable when test results fall below a Miller Number or SAR Number of 15 because of the small amount of mass loss from the wear specimens and potential for measurement error. 
Many factors affect the degree of abrasivity. The factors are corrosion, solids concentration, solids particle size, shape, hardness, and agglomeration. The degree of corrosion and the synergistic effect of corrosion and erosion can not be separated from the erosion process in the G75 Test.

Initially single bottles of $20 \%$ by mass slurry were provided where White Rock Engineering Services mixed and transferred slurry to each of four troughs for the 304L and 316L tests. Some degree of mass loss variance was experienced between wear specimens of the same material during HLW Slurry Test S-1024. After experiencing the mixing and transfer problem, subsequent slurry samples were prepared by Westinghouse Savanna River with the required material for each trough in separate bottles. This worked well except we had one bottle of HLWwSBS Leached (Test S-1033) that appeared to have more solids on transfer to the testing trough that resulted in a high SAR Number and a variance of $60 \%$ between the two wear specimens. The test (S-1033R) was rerun with two fresh bottles of slurry with acceptable results.

Solid particle sizes in the slurries are smaller than $45 \mathrm{um}$. These particles are very small relative to most mineral slurries and lower SAR Numbers than observed would be expected. Some of the slurries tended to agglomerate that could have caused the solids to act as larger solid particles. Photomicrographs 60X and 200X of solids contained in slurry were taken by applying a drop of water to a small dried sample and mechanically separating as best we could. The colloidal forces that resulted in agglomeration were stronger in some of the slurries than others. The purpose of photomicrographs of the solid particles was to indicate the particle size, shape, and type of material of the large particles that may be different from the majority of the particles in the slurry. Many times quartz is observed in mineral slurries. This very hard and sharp material can be the major cause of the erosion wear. Particle sizes are considerably smaller than normally experienced in mineral slurries being pumped. No conclusions can be made in regard to actual particles other than the potential to agglomerate.

The metal wear specimen photomicrographs $10 \mathrm{X}$ and $60 \mathrm{X}$ are also presented. Wear specimens are positioned with the direction of motion in the horizontal plane. The $10 \mathrm{X}$ photomicrograph shows the full $1 / 2$ " width of the wear specimen and approximately $3 / 4$ " of the 1 " length. The $60 \mathrm{X}$ photomicrographs were taken of areas where there was in some cases unusual wear. The actual wear specimens were returned with the printed reports.

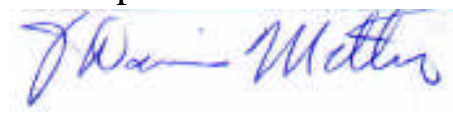

\section{J. Davis Miller, P. E.}




\section{Standard Miller Number Sand Slurry Test Results M-1023 \& M-1034}

The initial Miller Number test result was expected to have a Miller Number Range of from 139 to 154 based on Round Robin Test Data conducted in 1985 and documented in the ASTM G75 Standard Test Method for Determination of Slurry Abrasivity (Miller Number) and Slurry Abrasion Response (SAR Number). The current Miller Number Results of 129 and 117 are based on different batches of AFS 50-70 Test, 27\% Chrome Iron Wear Specimens, and Wear Laps. Miller Number System test results from data published ${ }^{1}$ in 1993 show that this standard test had a mass loss range of from 21 to $38 \mathrm{mg}$ during the first 4 hours of the test. The current 4 hour mass loss for the two 27\% Chrome Iron Wear Blocks were 31.4 \& $30.0 \mathrm{mg}$ for M-1023 and $27.7 \& 26.8 \mathrm{mg}$ for M-1034 conducted at the end of the tests. Both Miller Number tests mass loss fell in the middle of the range experienced for 25 tests conducted between 1982 and 1989.

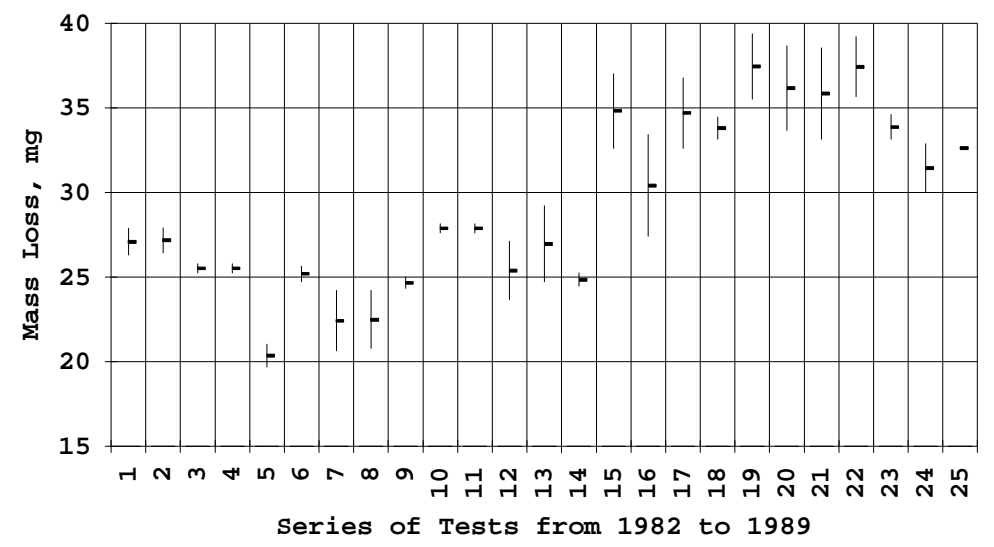

Table 4 - Standard AFS 50-70 Sand Test Results

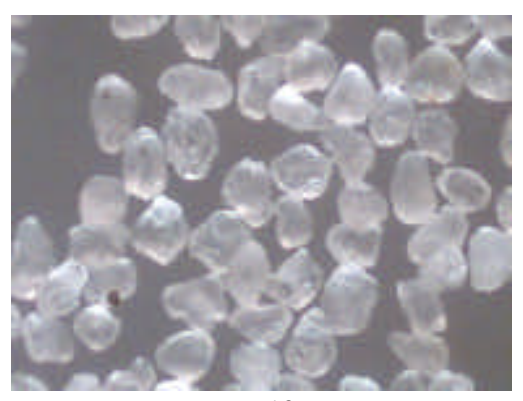

$60 X$

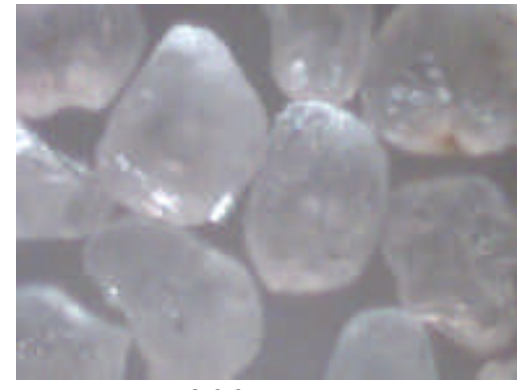

$200 X$

\footnotetext{
${ }^{1}$ Miller, J. E., and Miller, J. D., "The Miller Number - A Review", 12th International Conference on Slurry Handling and Pipeline Transport, HYDROTRANSPORT 12, Brugge, Belgium: 28-30 September 1993
} 
WSRC-TR-2002-00062, Rev. 0

SRT-RPP-2002-00022, Rev. 0

\section{ASTM G75 Slurry Abrasivity Determination \\ By Miller Number System}

\begin{tabular}{|c|c|c|c|c|c|c|c|c|}
\hline \multicolumn{9}{|l|}{ Test } \\
\hline Number & \multicolumn{8}{|l|}{ : M-1023 } \\
\hline Type & \multicolumn{8}{|c|}{ : Miller Number } \\
\hline Date & \multicolumn{8}{|c|}{ : 4-Jan-2001 } \\
\hline \multicolumn{9}{|l|}{ Project } \\
\hline Description & \multicolumn{8}{|c|}{ : Westinghouse Savannah River AB80166N } \\
\hline \multicolumn{9}{|c|}{ 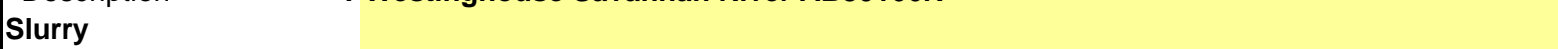 } \\
\hline Description & \multicolumn{8}{|c|}{ : AFS 50-70 Test Sand $150 \mathrm{~g}+150 \mathrm{ml}$ Distilled Water } \\
\hline Concentration & \multicolumn{8}{|c|}{ : $50 \%$ by Mass } \\
\hline Temperature & \multicolumn{8}{|c|}{$: 25 C+/-5 C$} \\
\hline \multicolumn{9}{|l|}{ Wear Specimen } \\
\hline Description & \multicolumn{8}{|c|}{ : 27\% Chrome Iron } \\
\hline Specific Gravity & \multicolumn{8}{|c|}{ : 7.58} \\
\hline Hardness & \multicolumn{8}{|l|}{ : $60 \mathrm{Rc}$} \\
\hline \multicolumn{9}{|l|}{ Lap Material } \\
\hline Description & \multicolumn{8}{|c|}{ : MIL-R-6855 CLASS 2 GRADE 80 NEOPRENE } \\
\hline Hardness - Durometer & \multicolumn{8}{|c|}{$: 78-82$} \\
\hline Wear- $\mathrm{mm}$ & \multicolumn{8}{|l|}{$: 0.02$} \\
\hline \multirow[t]{2}{*}{ Wear Specimen } & \multicolumn{3}{|c|}{ Wear Block 1} & \multicolumn{3}{|c|}{ Wear Block 2} & \multicolumn{2}{|c|}{ Cumm Loss } \\
\hline & $\mathrm{pH}$ & $\begin{array}{c}\text { Mass } \\
\mathrm{g}\end{array}$ & $\begin{array}{c}\text { Loss } \\
\text { mg }\end{array}$ & $\mathrm{pH}$ & $\begin{array}{c}\text { Mass } \\
\mathrm{g}\end{array}$ & $\begin{array}{c}\text { Loss } \\
\text { mg }\end{array}$ & $\begin{array}{c}\text { Ave } \\
\text { mg }\end{array}$ & $\begin{array}{c}{ }^{*} \text { Best Fit } \\
\text { mg }\end{array}$ \\
\hline Initial & 7.5 & 20.5723 & 0.0 & 7.5 & 20.7098 & 0.0 & 0.0 & 0.0 \\
\hline After 2 Hours & 6.7 & 20.5546 & 17.7 & 6.7 & 20.6933 & 16.5 & 17.1 & 17.1 \\
\hline After 4 Hours & 7.0 & 20.5409 & 13.7 & 7.0 & 20.6798 & 13.5 & 30.7 & 30.4 \\
\hline After 6 Hours & 7.0 & 20.5284 & 12.5 & 7.0 & 20.6684 & 11.4 & 42.7 & 42.7 \\
\hline Total & & & 43.9 & & & 41.4 & & \\
\hline
\end{tabular}

\begin{tabular}{|llcl|}
\hline Results & & & \\
${ }^{*}$ Best Fit Mass Loss & $:$ & $=$ & \multicolumn{1}{c|}{$9.6051{ }^{*}$ Hours ${ }^{\wedge} 0.83212$} \\
Miller Number & $:$ & 129.34 & Relative Rate of Mass/Volume loss at 2 hours \\
Departure & $:$ & $-8 \%$ & Relative Rate of Change in Mass/Volume loss at 2 hours \\
Lap Wear & $:$ & 0.02 & $\mathrm{~mm}$ \\
\hline
\end{tabular}

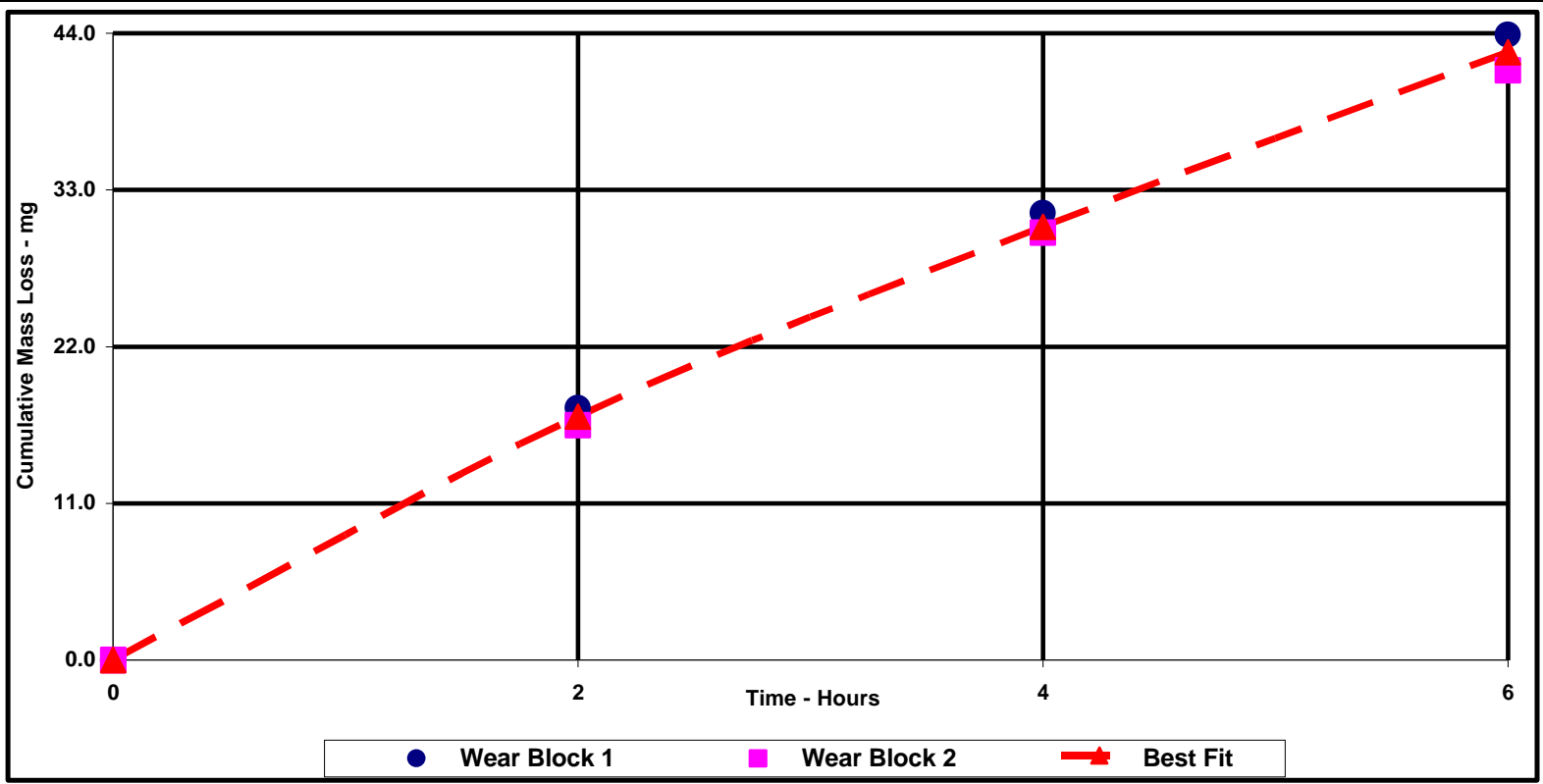


WSRC-TR-2002-00062, Rev. 0

SRT-RPP-2002-00022, Rev. 0

\section{ASTM G75 Slurry Abrasivity Determination By Miller Number System}

\begin{tabular}{|c|c|c|c|c|c|c|c|c|}
\hline \multicolumn{9}{|l|}{ Test } \\
\hline Number & \multicolumn{8}{|c|}{ : M-1023I } \\
\hline Type & \multicolumn{8}{|c|}{ : Miller Number } \\
\hline Date & \multicolumn{8}{|c|}{ : 4-Jan-2001 } \\
\hline \multicolumn{9}{|l|}{ Project } \\
\hline Description & \multicolumn{8}{|c|}{ : Westinghouse Savannah River AB80166N } \\
\hline \multicolumn{9}{|l|}{ Slurry } \\
\hline Description & \multicolumn{8}{|c|}{ : AFS 50-70 Test Sand $150 \mathrm{~g}+150 \mathrm{ml}$ Distilled Water $+\mathrm{Ca}(\mathrm{OH}) 2$ Inhibited } \\
\hline Concentration & \multicolumn{8}{|c|}{ : $50 \%$ by Mass } \\
\hline Temperature & \multicolumn{8}{|c|}{$: 25 C+/-5 C$} \\
\hline \multicolumn{9}{|l|}{ Wear Specimen } \\
\hline Description & \multicolumn{8}{|c|}{ : 27\% Chrome Iron } \\
\hline Specific Gravity & \multicolumn{8}{|c|}{ : 7.58} \\
\hline Hardness & \multicolumn{8}{|l|}{ : $60 \mathrm{Rc}$} \\
\hline \multicolumn{9}{|l|}{ Lap Material } \\
\hline Description & \multicolumn{8}{|c|}{ : MIL-R-6855 CLASS 2 GRADE 80 NEOPRENE } \\
\hline Hardness - Durometer & \multicolumn{8}{|c|}{$: 78-82$} \\
\hline Wear- mm & \multicolumn{8}{|l|}{$: 0.02$} \\
\hline \multirow[t]{2}{*}{ Wear Specimen } & \multicolumn{3}{|c|}{ Wear Block 3} & \multicolumn{3}{|c|}{ Wear Block 4} & \multicolumn{2}{|c|}{ Cumm Loss } \\
\hline & $\mathrm{pH}$ & $\begin{array}{c}\text { Mass } \\
\mathrm{g}\end{array}$ & $\begin{array}{c}\text { Loss } \\
\mathrm{mg}\end{array}$ & $\mathrm{pH}$ & $\begin{array}{c}\text { Mass } \\
\mathrm{g}\end{array}$ & $\begin{array}{c}\text { Loss } \\
\text { mg }\end{array}$ & $\begin{array}{l}\text { Ave } \\
\text { mg }\end{array}$ & $\begin{array}{c}{ }^{*} \text { Best Fit } \\
\text { mg }\end{array}$ \\
\hline Initial & 12.5 & 20.0418 & 0.0 & 12.6 & 20.4448 & 0.0 & 0.0 & 0.0 \\
\hline After 2 Hours & $7.5 / 12.5$ & 20.0273 & 14.5 & 7.6/12.5 & 20.4333 & 11.5 & 13.0 & 13.0 \\
\hline After 4 Hours & :10.2/12.5 & 20.0158 & 11.5 & $11.4 / 12.5$ & 20.4247 & 8.6 & 23.0 & 22.4 \\
\hline After 6 Hours & $: 11.3$ & 20.0080 & 7.8 & 9.8 & 20.4169 & 7.8 & 30.9 & 30.9 \\
\hline Total & $:$ & & 33.8 & & & 27.9 & & \\
\hline
\end{tabular}

\begin{tabular}{|llcl|}
\hline Results & & & \\
${ }^{*}$ Best Fit Mass Loss & $:$ & $=$ & \multicolumn{1}{c|}{$7.5322{ }^{*}$ Hours^ 0.78736} \\
Miller Number & $:$ & 93.04 & Relative Rate of Mass/Volume loss at 2 hours \\
Departure & $:$ & $-11 \%$ & Relative Rate of Change in Mass/Volume loss at 2 hours \\
Lap Wear & $:$ & 0.02 & $\mathrm{~mm}$ \\
\hline
\end{tabular}

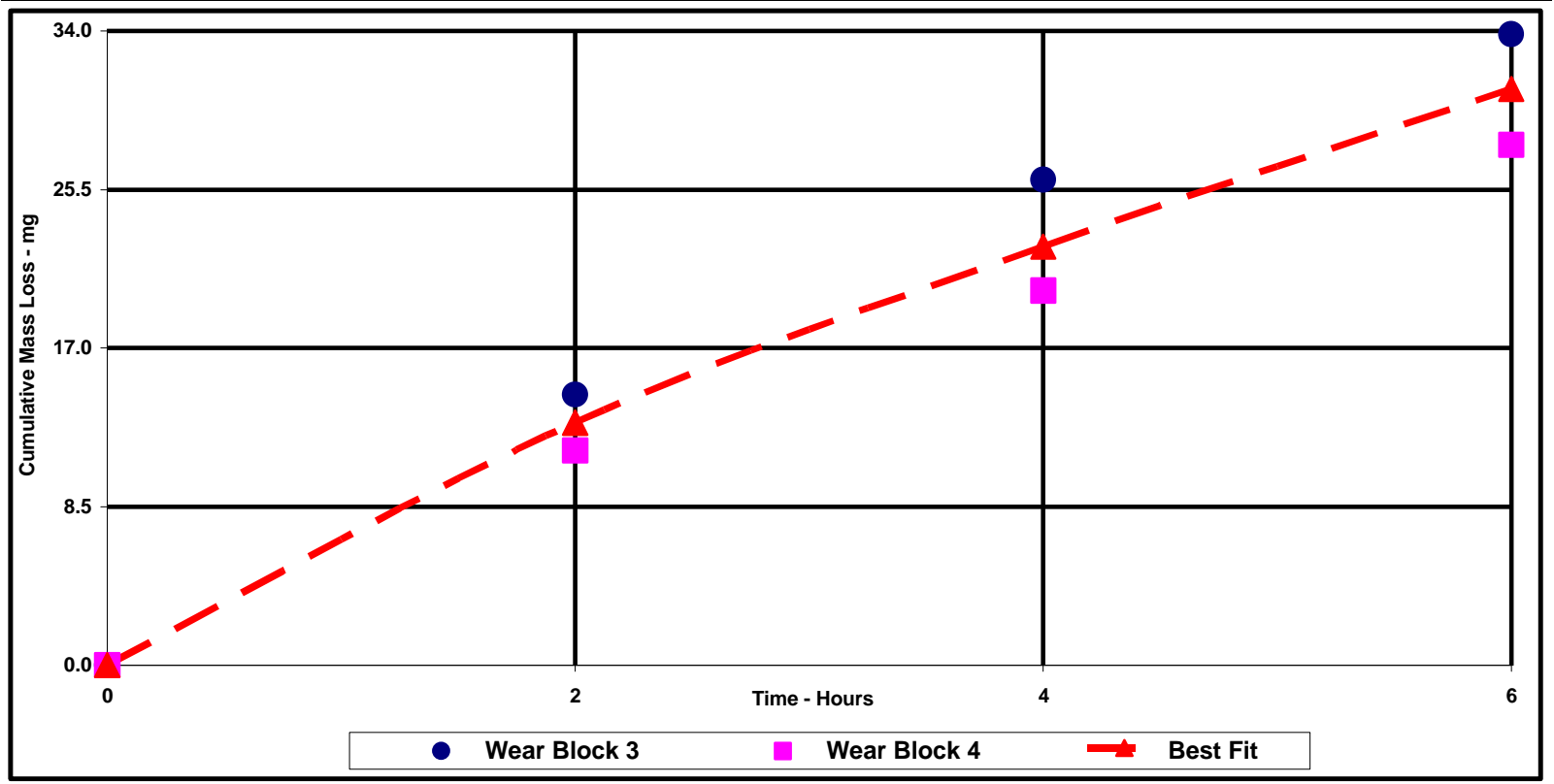


WSRC-TR-2002-00062, Rev. 0

SRT-RPP-2002-00022, Rev. 0

\section{ASTM G75 Slurry Abrasivity Determination By Miller Number System}

\begin{tabular}{|c|c|c|c|c|c|c|c|c|}
\hline \multicolumn{9}{|l|}{ Test } \\
\hline Number & \multicolumn{8}{|l|}{ : M-1034 } \\
\hline Type & \multicolumn{8}{|c|}{ : Miller Number } \\
\hline Date & \multicolumn{8}{|c|}{ : 2-Nov-2001 } \\
\hline \multicolumn{9}{|l|}{ Project } \\
\hline Description & \multicolumn{8}{|c|}{ : Westinghouse Savannah River AB80166N } \\
\hline \multicolumn{9}{|l|}{ Slurry } \\
\hline Description & \multicolumn{8}{|c|}{ : AFS 50-70 Test Sand $150 \mathrm{~g}+150 \mathrm{ml}$ Distilled Water } \\
\hline Concentration & \multicolumn{8}{|c|}{ : $50 \%$ by Mass } \\
\hline Temperature & \multicolumn{8}{|c|}{$: 25 C+/-5 C$} \\
\hline \multicolumn{9}{|l|}{ Wear Specimen } \\
\hline Description & \multicolumn{8}{|c|}{ : 27\% Chrome Iron } \\
\hline Specific Gravity & \multicolumn{8}{|c|}{$: 7.58$} \\
\hline Hardness & \multicolumn{8}{|l|}{ : $60 \mathrm{Rc}$} \\
\hline \multicolumn{9}{|l|}{ Lap Material } \\
\hline Description & \multicolumn{8}{|c|}{ : MIL-R-6855 CLASS 2 GRADE 80 NEOPRENE } \\
\hline Hardness - Durometer & \multicolumn{8}{|c|}{ : 78-82 } \\
\hline Wear - mm & \multicolumn{8}{|l|}{$: 0.02$} \\
\hline \multirow[t]{2}{*}{ Wear Specimen } & \multicolumn{3}{|c|}{ Wear Block 1} & \multicolumn{3}{|c|}{ Wear Block 2} & \multicolumn{2}{|c|}{ Cumm Loss } \\
\hline & $\mathrm{pH}$ & $\begin{array}{c}\text { Mass } \\
\mathrm{g}\end{array}$ & $\begin{array}{c}\text { Loss } \\
\text { mg }\end{array}$ & $\mathrm{pH}$ & $\begin{array}{c}\text { Mass } \\
\mathrm{g}\end{array}$ & $\begin{array}{c}\text { Loss } \\
\mathrm{mg}\end{array}$ & $\begin{array}{l}\text { Ave } \\
\text { mg }\end{array}$ & $\begin{array}{c}{ }^{*} \text { Best Fit } \\
\text { mg }\end{array}$ \\
\hline Initial & 8.9 & 17.7900 & 0.0 & 8.9 & 17.8700 & 0.0 & 0.0 & 0.0 \\
\hline After 2 Hours & 8.5 & 17.7751 & 14.9 & 8.4 & 17.8554 & 14.6 & 14.8 & 14.8 \\
\hline After 4 Hours & 8.7 & 17.7623 & 12.8 & 8.4 & 17.8432 & 12.2 & 27.3 & 27.0 \\
\hline After 6 Hours & 8.7 & 17.7505 & 11.8 & 8.5 & 17.8325 & 10.7 & 38.5 & 38.5 \\
\hline Total & $:$ & & 39.5 & & & 37.5 & & \\
\hline
\end{tabular}

\begin{tabular}{|llcl|}
\hline Results & & & \\
${ }^{*}$ Best Fit Mass Loss & $:$ & $=$ & $8.0515{ }^{*}$ Hours^ 0.87339 \\
Miller Number & $:$ & 117.10 & Relative Rate of Mass/Volume loss at 2 hours \\
Departure & $:$ & $-6 \%$ & Relative Rate of Change in Mass/Volume loss at 2 hours \\
Lap Wear & $:$ & 0.02 & $\mathrm{~mm}$ \\
\hline
\end{tabular}

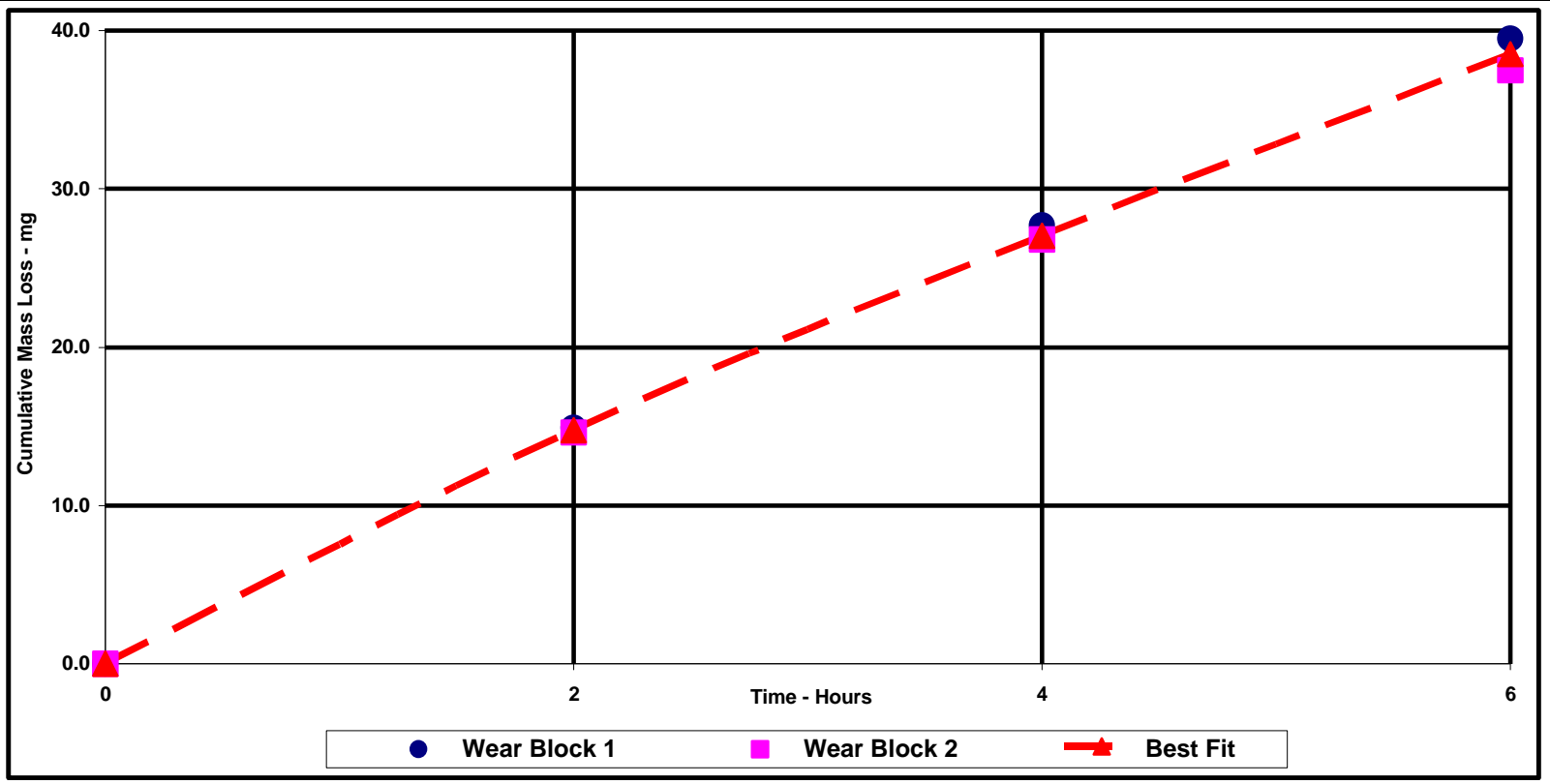


WSRC-TR-2002-00062, Rev. 0

SRT-RPP-2002-00022, Rev. 0

\section{ASTM G75 Slurry Abrasivity Determination By Miller Number System}

\begin{tabular}{|c|c|c|c|c|c|c|c|c|}
\hline \multicolumn{9}{|l|}{ Test } \\
\hline Number & \multicolumn{8}{|c|}{ : M-1034I } \\
\hline Type & \multicolumn{8}{|c|}{ : Miller Number } \\
\hline Date & \multicolumn{8}{|c|}{ : 2-Nov-2001 } \\
\hline \multicolumn{9}{|l|}{ Project } \\
\hline Description & \multicolumn{8}{|c|}{ : Westinghouse Savannah River AB80166N } \\
\hline \multicolumn{9}{|c|}{ 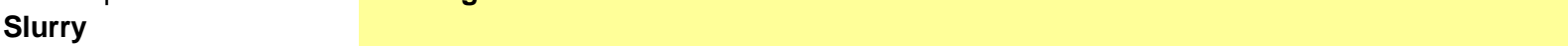 } \\
\hline Description & \multicolumn{8}{|c|}{ : AFS 50-70 Test Sand $150 \mathrm{~g}+150 \mathrm{ml}$ Distilled Water + $\mathrm{Ca}(\mathrm{OH}) 2$ Inhibited } \\
\hline Concentration & \multicolumn{8}{|c|}{ : $50 \%$ by Mass } \\
\hline Temperature & \multicolumn{8}{|c|}{$: 25 C+/-5 C$} \\
\hline \multicolumn{9}{|l|}{ Wear Specimen } \\
\hline Description & \multicolumn{8}{|c|}{ : 27\% Chrome Iron } \\
\hline Specific Gravity & \multicolumn{8}{|c|}{$: 7.58$} \\
\hline Hardness & \multicolumn{8}{|l|}{ : $60 \mathrm{Rc}$} \\
\hline \multicolumn{9}{|l|}{ Lap Material } \\
\hline Description & \multicolumn{8}{|c|}{ : MIL-R-6855 CLASS 2 GRADE 80 NEOPRENE } \\
\hline Hardness - Durometer & \multicolumn{8}{|c|}{ : 78-82 } \\
\hline Wear - $\mathrm{mm}$ & \multicolumn{8}{|l|}{$: 0.02$} \\
\hline \multirow[t]{2}{*}{ Wear Specimen } & \multicolumn{3}{|c|}{ Wear Block 3} & \multicolumn{3}{|c|}{ Wear Block 4} & \multicolumn{2}{|c|}{ Cumm Loss } \\
\hline & $\overline{\mathrm{pH}}$ & $\begin{array}{c}\text { Mass } \\
\mathrm{g}\end{array}$ & $\begin{array}{c}\text { Loss } \\
\mathrm{mg}\end{array}$ & $\overline{\mathrm{pH}}$ & $\begin{array}{c}\text { Mass } \\
\mathrm{g}\end{array}$ & $\begin{array}{c}\text { Loss } \\
\mathrm{mg}\end{array}$ & $\begin{array}{l}\text { Ave } \\
\mathrm{mg}\end{array}$ & $\begin{array}{c}{ }^{*} \text { Best Fit } \\
\text { mg }\end{array}$ \\
\hline Initial & 12.8 & 18.2587 & 0.0 & 12.8 & 18.8054 & 0.0 & 0.0 & 0.0 \\
\hline After 2 Hours & 12.8 & 18.2498 & 8.9 & 12.8 & 18.7965 & 8.9 & 8.9 & 8.9 \\
\hline After 4 Hours & 12.8 & 18.2412 & 8.6 & 12.8 & 18.7876 & 8.9 & 17.6 & 17.1 \\
\hline After 6 Hours & 12.7 & 18.2342 & 7.0 & 12.4 & 18.7796 & 8.0 & 25.2 & 25.1 \\
\hline Total & $:$ & & 24.5 & & & 25.8 & & \\
\hline
\end{tabular}

\begin{tabular}{|llcl|}
\hline Results & & \multicolumn{1}{c|}{$4.6241{ }^{*}$ Hours^ 0.94464} \\
${ }^{*}$ Best Fit Mass Loss & $:$ & $=$ & \multicolumn{1}{c|}{ Hellive Rate of Mass/Volume loss at 2 hours } \\
Miller Number & $:$ & 76.42 & Relative \\
Departure & $:$ & $-3 \%$ & Relative Rate of Change in Mass/Volume loss at 2 hours \\
Lap Wear & $:$ & 0.02 & $\mathrm{~mm}$ \\
\hline
\end{tabular}

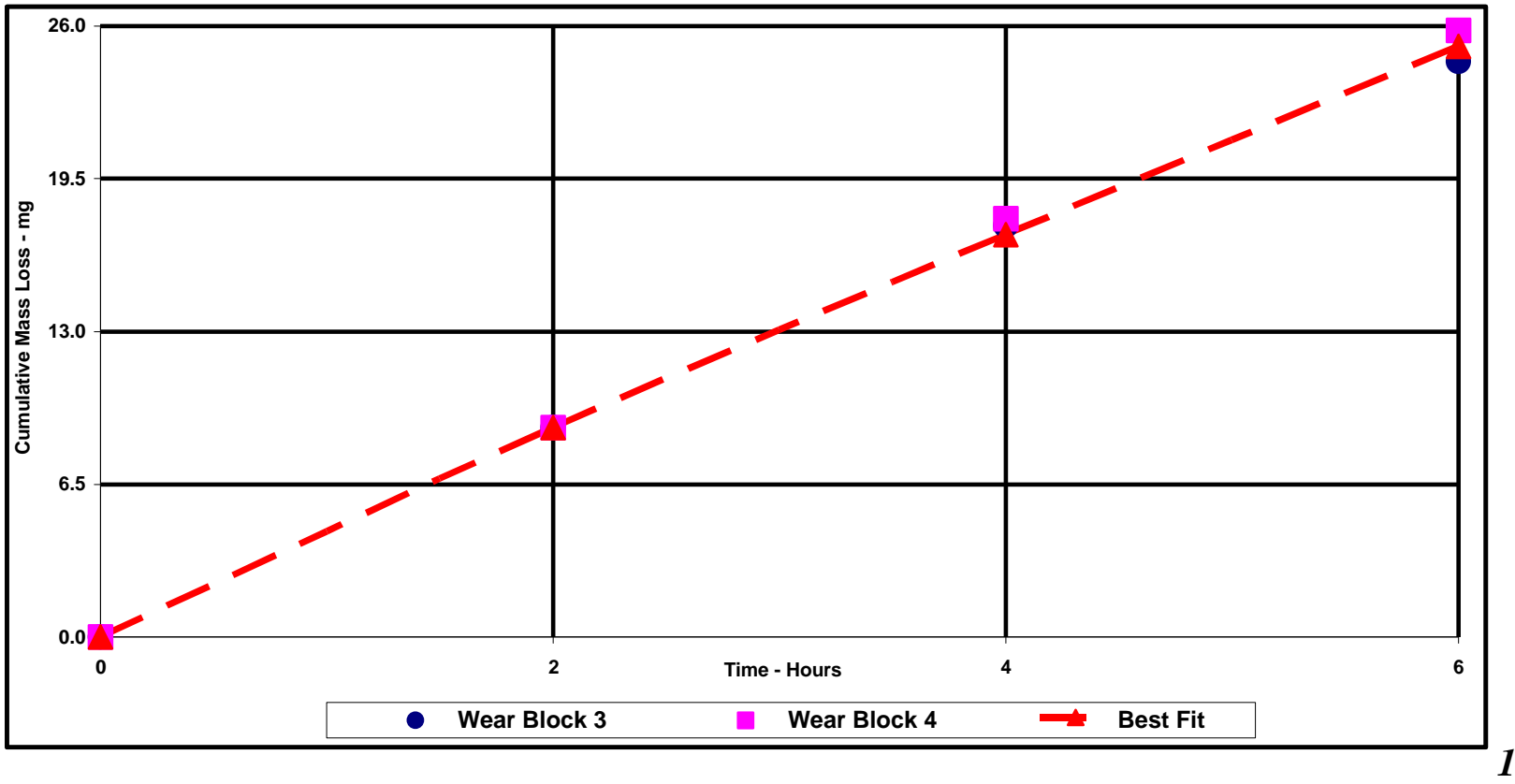


RPP-WTP Slurry Wear Evaluation: Slurry Abrasivity

WSRC-TR-2002-00062, Rev. 0

SRT-RPP-2002-00022, Rev. 0

1 - HLW Slurry Tst Results S-1024(304L SS) and S-1025(316L SS)
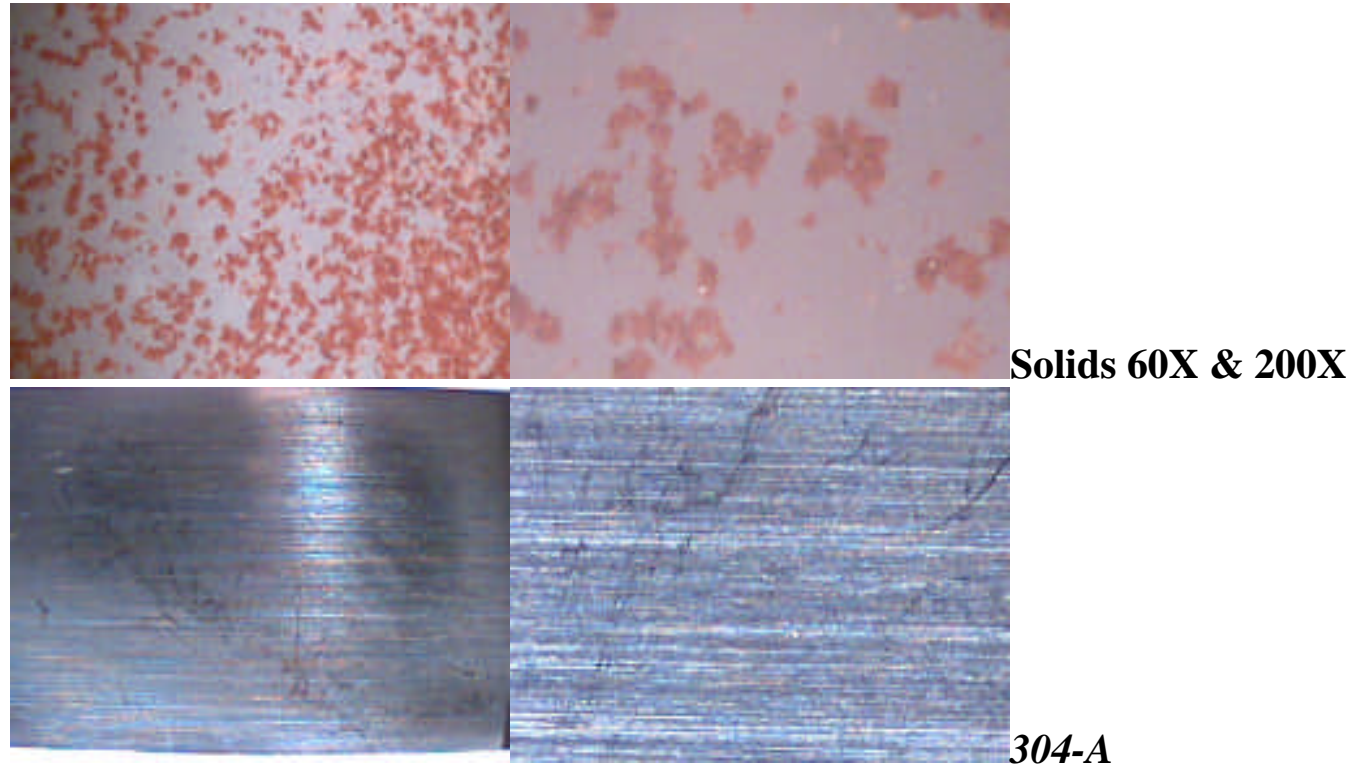

Solids 60X \& 200X

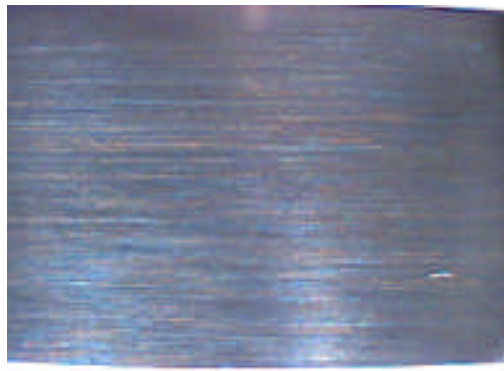

304- $A$
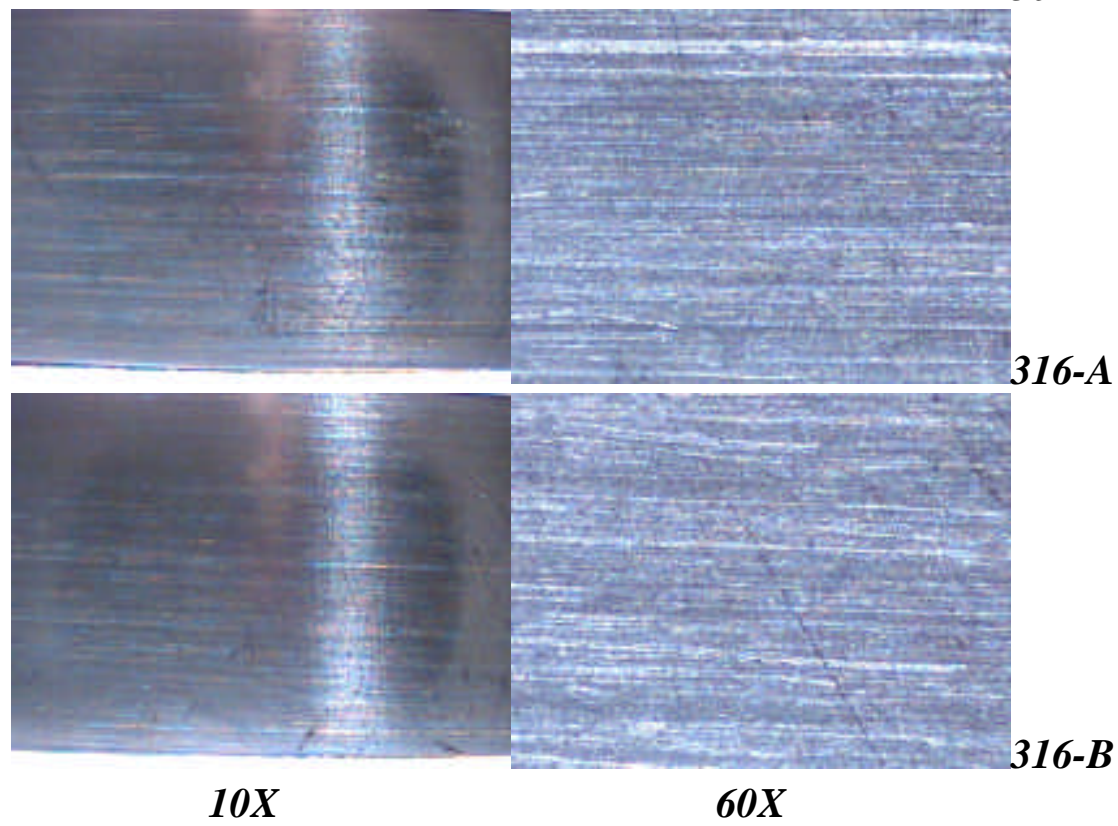
WSRC-TR-2002-00062, Rev. 0

SRT-RPP-2002-00022, Rev. 0

\section{ASTM G75 Slurry Abrasivity Determination By Miller Number System}

\begin{tabular}{|c|c|c|c|c|c|c|c|c|}
\hline \multicolumn{9}{|l|}{ Test } \\
\hline Number & \multicolumn{8}{|l|}{ : S-1024 } \\
\hline Type & \multicolumn{8}{|c|}{ : SAR Number } \\
\hline Date & \multicolumn{8}{|c|}{ : 21-Mar-2001 } \\
\hline \multicolumn{9}{|l|}{ Project } \\
\hline Description & \multicolumn{8}{|c|}{ : Westinghouse Savannah River - AB80166N } \\
\hline \multicolumn{9}{|l|}{ Slurry } \\
\hline Description & \multicolumn{8}{|c|}{ : Test 1 - HLW - 230ml 265 grams } \\
\hline Concentration & \multicolumn{8}{|c|}{ : $20 \%$ by Mass (as received) } \\
\hline Temperature & \multicolumn{8}{|c|}{$: 25 C+/-5$} \\
\hline \multicolumn{9}{|l|}{ Wear Specimen } \\
\hline Description & \multicolumn{8}{|c|}{ : 304L Stainless Steel } \\
\hline Specific Gravity & \multicolumn{8}{|c|}{$: 7.96$} \\
\hline Hardness & \multicolumn{8}{|l|}{ : NA } \\
\hline \multicolumn{9}{|l|}{ Lap Material } \\
\hline Description & \multicolumn{8}{|c|}{ : MIL-R-6855 CLASS 2 GRADE 80 NEOPRENE } \\
\hline Hardness - Durometer & \multicolumn{8}{|c|}{$: 78-82$} \\
\hline Wear - mm & \multicolumn{8}{|l|}{$: 0.01$} \\
\hline \multirow[t]{2}{*}{ Wear Specimen } & \multicolumn{3}{|c|}{ 304L 1A } & \multicolumn{3}{|c|}{ 304L 1B } & \multicolumn{2}{|c|}{ Cumm Loss } \\
\hline & $\mathrm{pH}$ & $\begin{array}{c}\text { Mass } \\
\mathrm{g}\end{array}$ & $\begin{array}{c}\text { Loss } \\
\text { mg }\end{array}$ & $\mathrm{pH}$ & $\begin{array}{c}\text { Mass } \\
g\end{array}$ & $\begin{array}{c}\text { Loss } \\
\text { mg }\end{array}$ & $\begin{array}{c}\text { Ave } \\
\text { mg }\end{array}$ & $\begin{array}{c}{ }^{*} \text { Best Fit } \\
\text { mg }\end{array}$ \\
\hline Initial & 13.3 & 15.9065 & 0.0 & 13.3 & 15.9322 & 0.0 & 0.0 & 0.0 \\
\hline After 2 Hours & 13.2 & 15.8837 & 22.8 & 13.2 & 15.9093 & 22.9 & 22.9 & 22.2 \\
\hline After 4 Hours & 13.2 & 15.8730 & 10.7 & 13.2 & 15.8928 & 16.5 & 36.5 & 39.0 \\
\hline After 6 Hours & 13.2 & 15.8584 & 14.6 & 13.2 & 15.8719 & 20.9 & 54.2 & 54.2 \\
\hline Total & $:$ & & 48.1 & & & 60.3 & & \\
\hline
\end{tabular}

\begin{tabular}{|llcl|}
\hline Results & & & \\
*Best Fit Mass Loss & $:$ & $=$ & $12.6330{ }^{*}$ Hours^ 0.81282 \\
SAR Number & $:$ & 156.13 & Relative Rate of Mass/Volume loss at 2 hours \\
Departure & $:$ & $-9 \%$ & Relative Rate of Change in Mass/Volume loss at 2 hours \\
Lap Wear & $:$ & 0.01 & $\mathrm{~mm}$ \\
\hline
\end{tabular}

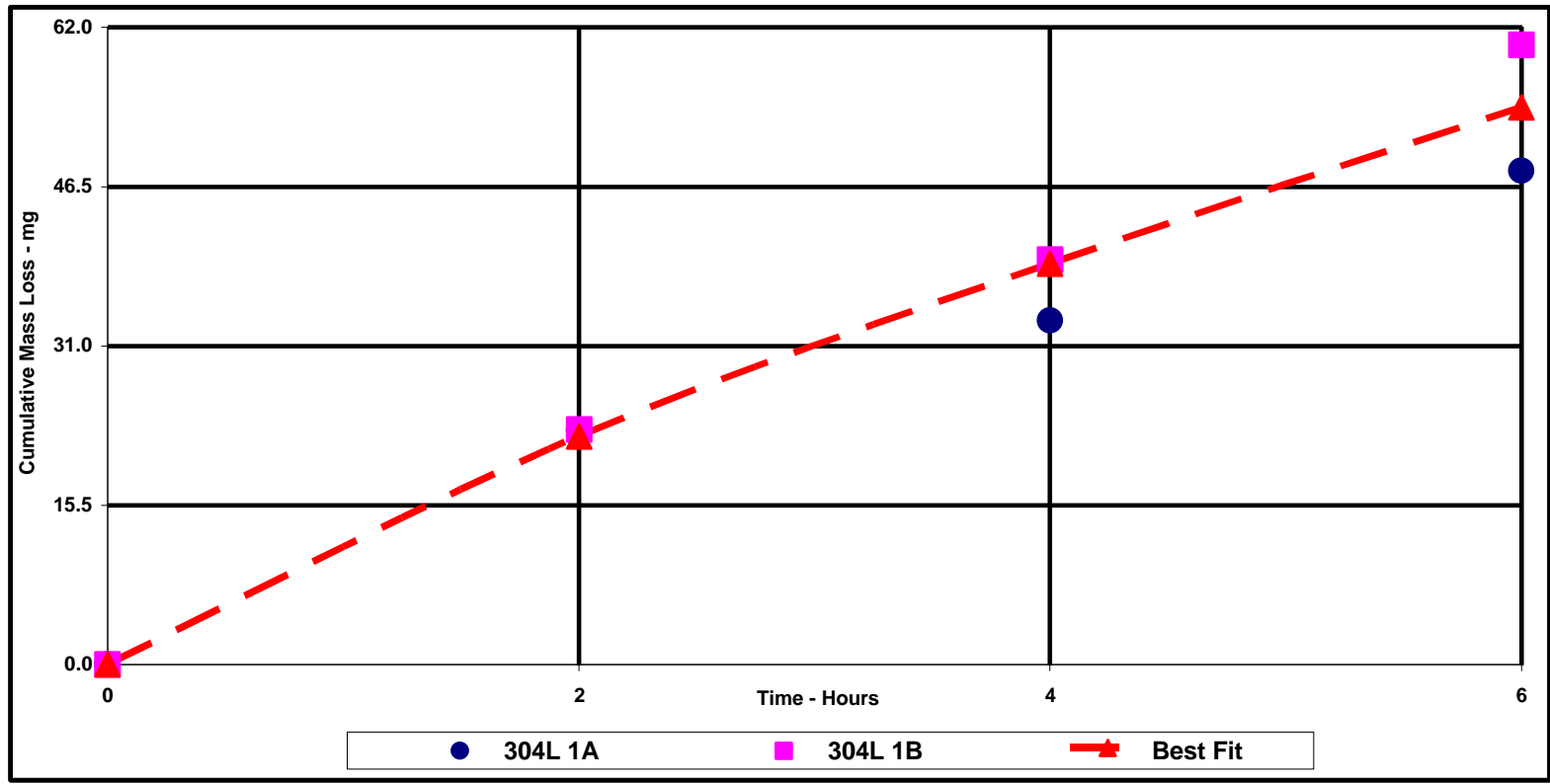


WSRC-TR-2002-00062, Rev. 0

SRT-RPP-2002-00022, Rev. 0

\section{ASTM G75 Slurry Abrasivity Determination By Miller Number System}

\begin{tabular}{|c|c|c|c|c|c|c|c|c|}
\hline \multicolumn{9}{|l|}{ Test } \\
\hline Number & \multicolumn{8}{|l|}{ : S-1025 } \\
\hline Type & \multicolumn{8}{|c|}{ : SAR Number } \\
\hline Date & \multicolumn{8}{|c|}{ : 21-Mar-2001 } \\
\hline \multicolumn{9}{|l|}{ Project } \\
\hline Description & \multicolumn{8}{|c|}{ : Westinghouse Savannah River - AB80166N } \\
\hline \multicolumn{9}{|l|}{ Slurry } \\
\hline Description & \multicolumn{8}{|c|}{ : Test 1 - HLW - 230ml 265 grams } \\
\hline Concentration & \multicolumn{8}{|c|}{ : $20 \%$ by Mass (as received) } \\
\hline Temperature & \multicolumn{8}{|c|}{$: 25 C+/-5$} \\
\hline \multicolumn{9}{|l|}{ Wear Specimen } \\
\hline Description & \multicolumn{8}{|c|}{ : 316L Stainless Steel } \\
\hline Specific Gravity & \multicolumn{8}{|c|}{$: 8.00$} \\
\hline Hardness & \multicolumn{8}{|l|}{ : NA } \\
\hline \multicolumn{9}{|l|}{ Lap Material } \\
\hline Description & \multicolumn{8}{|c|}{ : MIL-R-6855 CLASS 2 GRADE 80 NEOPRENE } \\
\hline Hardness - Durometer & \multicolumn{8}{|c|}{ : 78-82 } \\
\hline Wear - mm & \multicolumn{8}{|l|}{$: 0.01$} \\
\hline \multirow[t]{2}{*}{ Wear Specimen } & \multicolumn{3}{|c|}{ 316L 1A } & \multicolumn{3}{|c|}{ 316L 1B } & \multicolumn{2}{|c|}{ Cumm Loss } \\
\hline & $\mathrm{pH}$ & $\begin{array}{c}\text { Mass } \\
\mathrm{g}\end{array}$ & $\begin{array}{c}\text { Loss } \\
\mathrm{mg}\end{array}$ & $\mathrm{pH}$ & $\begin{array}{c}\text { Mass } \\
\mathrm{g}\end{array}$ & $\begin{array}{c}\text { Loss } \\
\text { mg }\end{array}$ & $\begin{array}{l}\text { Ave } \\
\text { mg }\end{array}$ & $\begin{array}{c}{ }^{*} \text { Best Fit } \\
\text { mg }\end{array}$ \\
\hline Initial & 13.2 & 15.8663 & 0.0 & 13.2 & 15.9125 & 0.0 & 0.0 & 0.0 \\
\hline After 2 Hours & 13.2 & 15.8451 & 21.2 & 13.2 & 15.8837 & 28.8 & 25.0 & 25.0 \\
\hline After 4 Hours & 13.2 & 15.8295 & 15.6 & 13.2 & 15.8669 & 16.8 & 41.2 & 40.7 \\
\hline After 6 Hours & 13.2 & 15.8186 & 10.9 & 13.2 & 15.8519 & 15.0 & 54.1 & 54.1 \\
\hline Total & $:$ & & 47.7 & & & 60.6 & & \\
\hline
\end{tabular}

\begin{tabular}{|llll|}
\hline Results & & & \\
${ }^{*}$ Best Fit Mass Loss & $:$ & $=$ & $15.3525{ }^{*}$ Hours^ 0.70346 \\
SAR Number & $:$ & 151.47 & Relative Rate of Mass/Volume loss at 2 hours \\
Departure & $:$ & $-15 \%$ & Relative Rate of Change in Mass/Volume loss at 2 hours \\
Lap Wear & $:$ & 0.01 & $\mathrm{~mm}$ \\
\hline
\end{tabular}

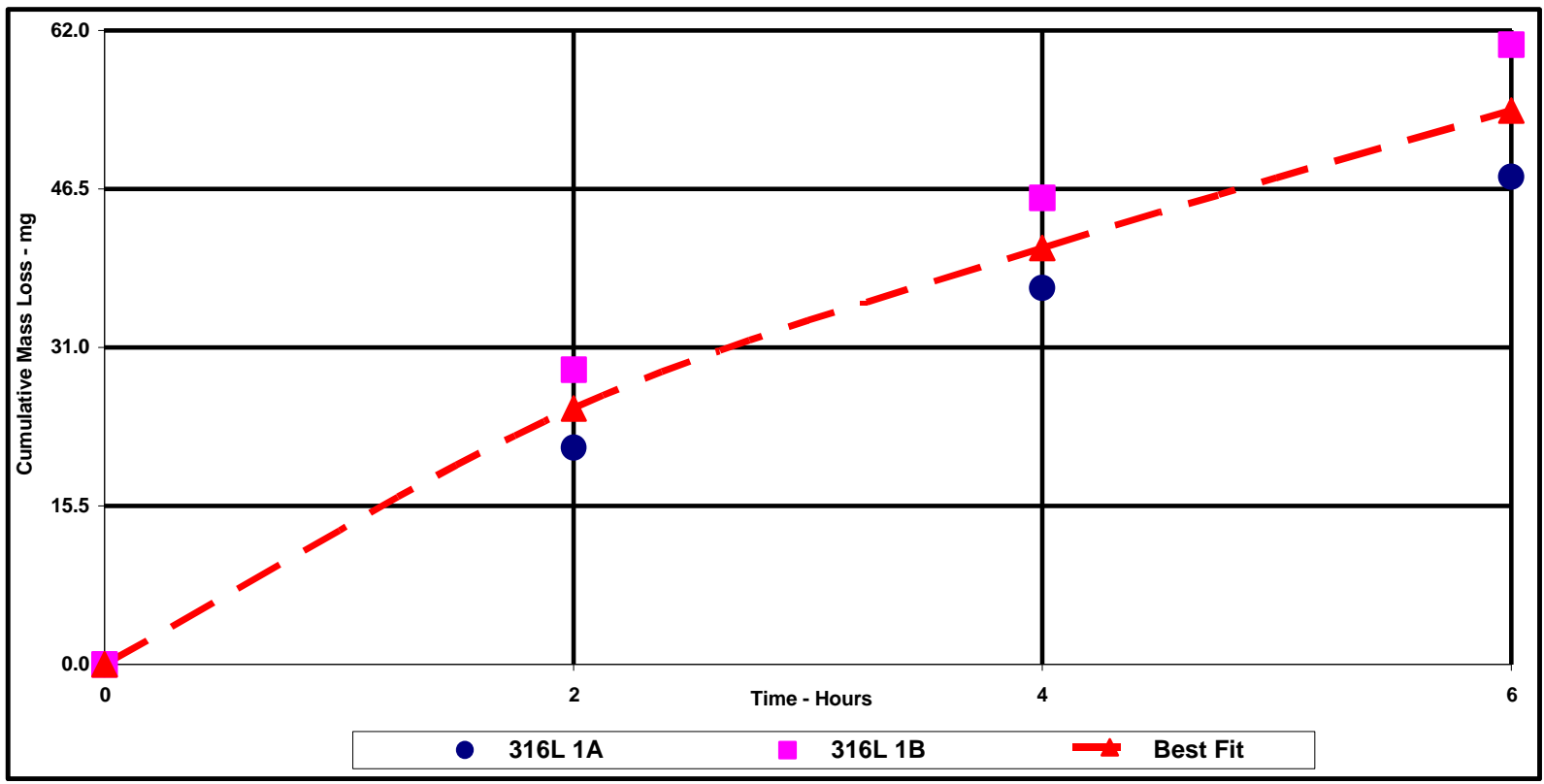


WSRC-TR-2002-00062, Rev. 0

SRT-RPP-2002-00022, Rev. 0

2 - HLWwSBS Slurry Test Results S-1026(304L SS) and S-1027(316L SS
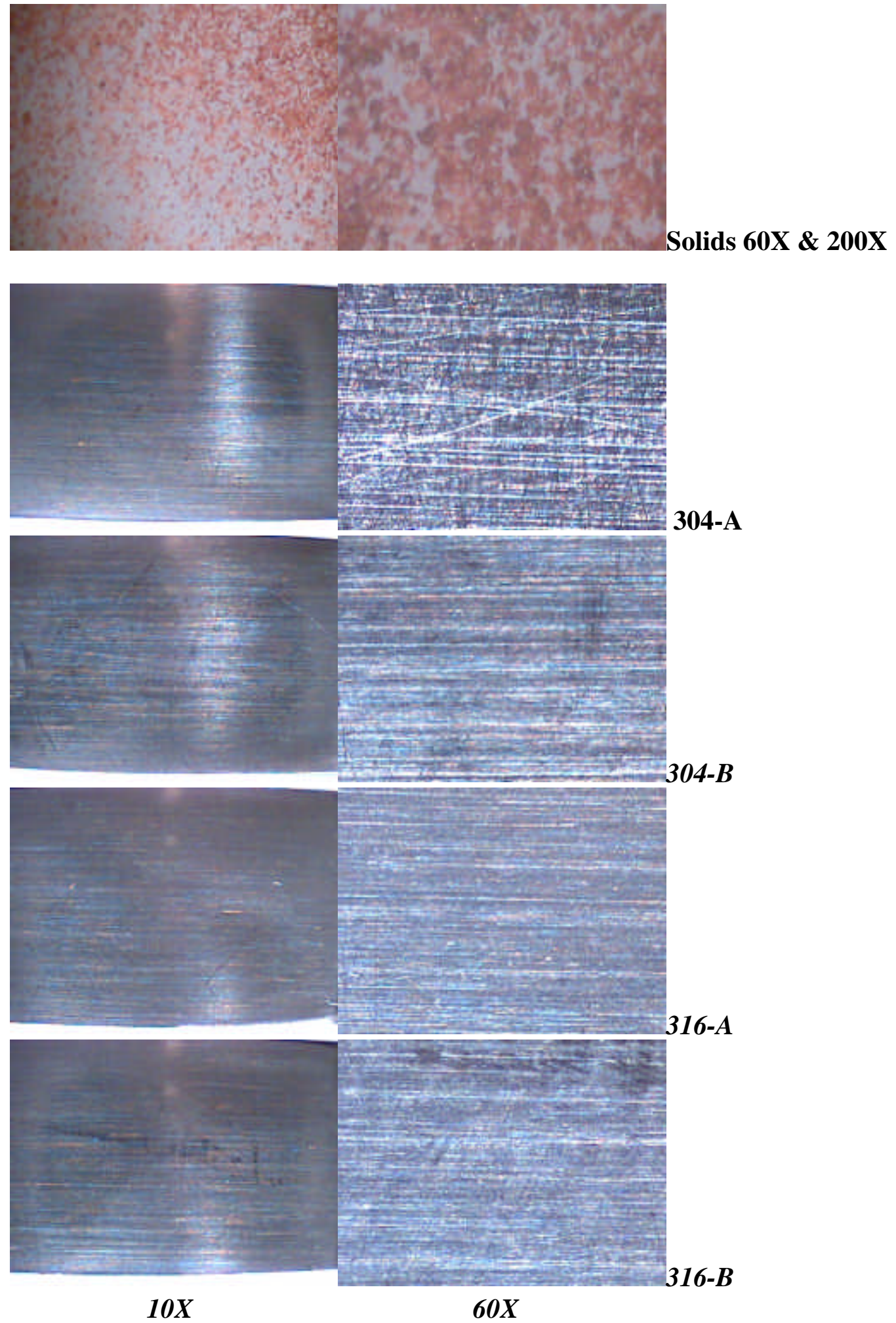
WSRC-TR-2002-00062, Rev. 0

SRT-RPP-2002-00022, Rev. 0

\section{ASTM G75 Slurry Abrasivity Determination By Miller Number System}

\begin{tabular}{|c|c|c|c|c|c|c|c|c|}
\hline \multicolumn{9}{|l|}{ Test } \\
\hline Number & \multicolumn{8}{|l|}{ : S-1026 } \\
\hline Type & \multicolumn{8}{|c|}{ : SAR Number } \\
\hline Date & \multicolumn{8}{|c|}{ : 6-Oct-2001 } \\
\hline \multicolumn{9}{|l|}{ Project } \\
\hline Description & \multicolumn{8}{|c|}{ : Westinghouse Savannah River - AB80166N } \\
\hline \multicolumn{9}{|l|}{ Slurry } \\
\hline Description & \multicolumn{8}{|c|}{ : Test 2 - HLWwSBS - $281 \& 288$ grams as received } \\
\hline Concentration & \multicolumn{8}{|c|}{ : $20 \%$ by Mass (as received) } \\
\hline Temperature & \multicolumn{8}{|c|}{$: 25 C+/-5$} \\
\hline \multicolumn{9}{|l|}{ Wear Specimen } \\
\hline Description & \multicolumn{8}{|c|}{ : 304L Stainless Steel } \\
\hline Specific Gravity & \multicolumn{8}{|c|}{$: 7.96$} \\
\hline Hardness & \multicolumn{8}{|l|}{ : NA } \\
\hline \multicolumn{9}{|l|}{ Lap Material } \\
\hline Description & \multicolumn{8}{|c|}{ : MIL-R-6855 CLASS 2 GRADE 80 NEOPRENE } \\
\hline Hardness - Durometer & \multicolumn{8}{|c|}{$: 78-82$} \\
\hline Wear - mm & \multicolumn{8}{|l|}{$: 0.01$} \\
\hline \multirow[t]{2}{*}{ Wear Specimen } & \multicolumn{3}{|c|}{ 304L 2A } & \multicolumn{3}{|c|}{ 304L 2B } & \multicolumn{2}{|c|}{ Cumm Loss } \\
\hline & $\mathrm{pH}$ & $\begin{array}{c}\text { Mass } \\
\mathrm{g}\end{array}$ & $\begin{array}{c}\text { Loss } \\
\text { mg }\end{array}$ & $\mathrm{pH}$ & $\begin{array}{c}\text { Mass } \\
g\end{array}$ & $\begin{array}{c}\text { Loss } \\
\text { mg }\end{array}$ & $\begin{array}{c}\text { Ave } \\
\text { mg }\end{array}$ & $\begin{array}{c}{ }^{*} \text { Best Fit } \\
\text { mg }\end{array}$ \\
\hline Initial & 12.9 & 15.6446 & 0.0 & 12.9 & 15.7398 & 0.0 & 0.0 & 0.0 \\
\hline After 2 Hours & 12.8 & 15.6264 & 18.2 & 12.8 & 15.7226 & 17.2 & 17.7 & 18.2 \\
\hline After 4 Hours & 12.9 & 15.6088 & 17.6 & 12.9 & 15.7007 & 21.9 & 37.5 & 37.2 \\
\hline After 6 Hours & 12.8 & 15.5844 & 24.4 & 12.8 & 15.6869 & 13.8 & 56.6 & 56.5 \\
\hline Total & $:$ & & 60.2 & & & 52.9 & & \\
\hline
\end{tabular}

\begin{tabular}{|llcl|}
\hline Results & & & \\
${ }^{*}$ Best Fit Mass Loss & $:$ & $=$ & $8.8624{ }^{*}$ Hours ${ }^{\wedge} 1.03435$ \\
SAR Number & $:$ & 162.52 & Relative Rate of Mass/Volume loss at 2 hours \\
Departure & $:$ & $2 \%$ & Relative Rate of Change in Mass/Volume loss at 2 hours \\
Lap Wear & $:$ & 0.01 & $\mathrm{~mm}$ \\
\hline
\end{tabular}

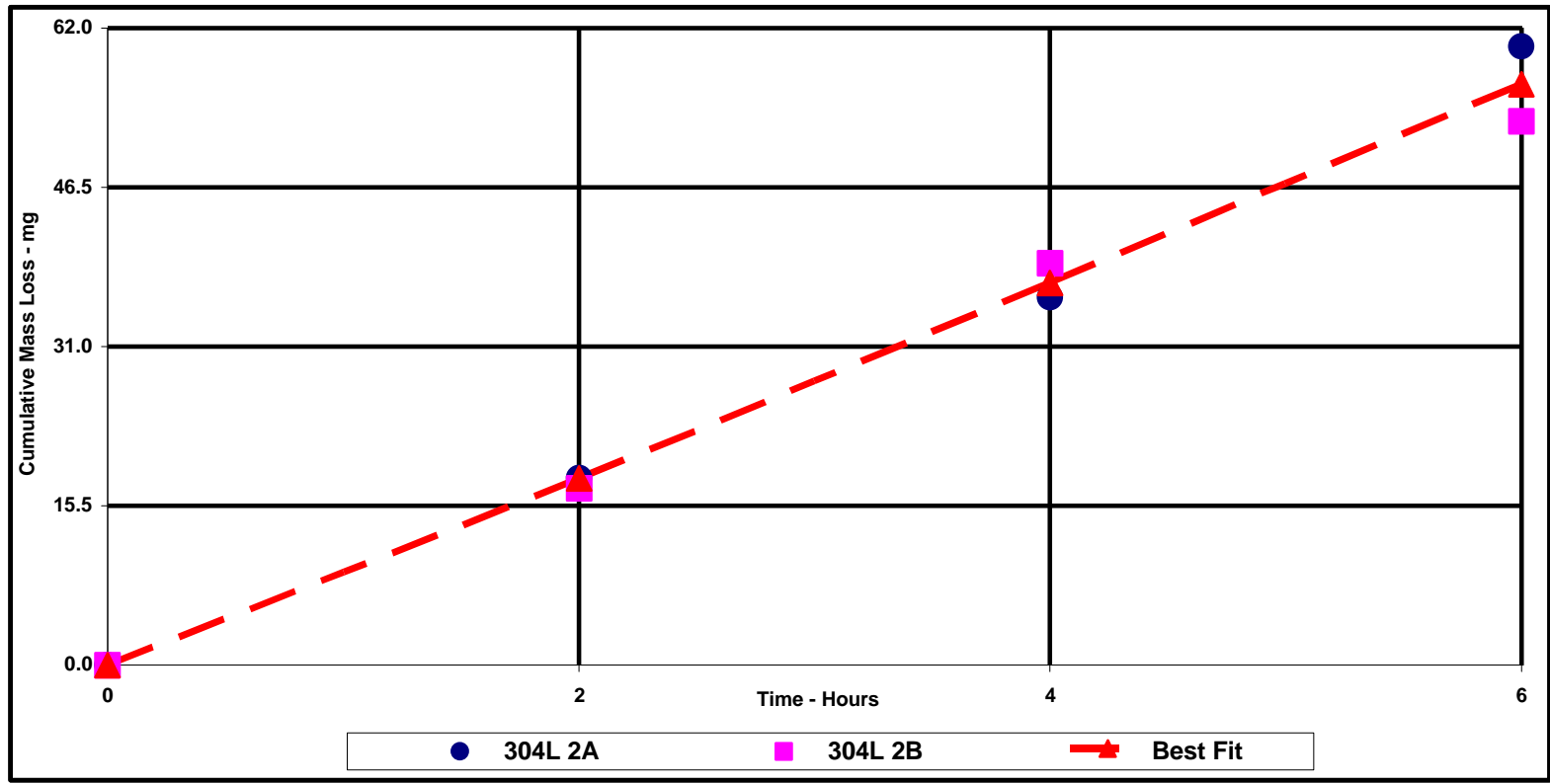


WSRC-TR-2002-00062, Rev. 0

SRT-RPP-2002-00022, Rev. 0

\section{ASTM G75 Slurry Abrasivity Determination By Miller Number System}

\begin{tabular}{|c|c|c|c|c|c|c|c|c|}
\hline \multicolumn{9}{|l|}{ Test } \\
\hline Number & \multicolumn{8}{|l|}{ : S-1027 } \\
\hline Type & \multicolumn{8}{|c|}{ : SAR Number } \\
\hline Date & \multicolumn{8}{|c|}{ : 6-Oct-2001 } \\
\hline \multicolumn{9}{|l|}{ Project } \\
\hline Description & \multicolumn{8}{|c|}{ : Westinghouse Savannah River - AB80166N } \\
\hline \multicolumn{9}{|l|}{ Slurry } \\
\hline Description & \multicolumn{8}{|c|}{ : Test 2 - HLWwSBS - $280 \& 301$ grams as received } \\
\hline Concentration & \multicolumn{8}{|c|}{ : $20 \%$ by Mass (as received) } \\
\hline Temperature & \multicolumn{8}{|c|}{$: 25 C+/-5$} \\
\hline \multicolumn{9}{|l|}{ Wear Specimen } \\
\hline Description & \multicolumn{8}{|c|}{ : 316L Stainless Steel } \\
\hline Specific Gravity & \multicolumn{8}{|c|}{$: 8.00$} \\
\hline Hardness & \multicolumn{8}{|l|}{ : NA } \\
\hline \multicolumn{9}{|l|}{ Lap Material } \\
\hline Description & \multicolumn{8}{|c|}{ : MIL-R-6855 CLASS 2 GRADE 80 NEOPRENE } \\
\hline Hardness - Durometer & \multicolumn{8}{|c|}{ : 78-82 } \\
\hline Wear - mm & \multicolumn{8}{|l|}{$: 0.01$} \\
\hline \multirow[t]{2}{*}{ Wear Specimen } & \multicolumn{3}{|c|}{ 316L 2A } & \multicolumn{3}{|c|}{ 316L 2B } & \multicolumn{2}{|c|}{ Cumm Loss } \\
\hline & $\mathrm{pH}$ & $\begin{array}{c}\text { Mass } \\
\mathrm{g}\end{array}$ & $\begin{array}{c}\text { Loss } \\
\text { mg }\end{array}$ & $\overline{\mathrm{pH}}$ & $\begin{array}{c}\text { Mass } \\
\mathrm{g}\end{array}$ & $\begin{array}{c}\text { Loss } \\
\text { mg }\end{array}$ & $\begin{array}{c}\text { Ave } \\
\text { mg }\end{array}$ & $\begin{array}{c}{ }^{*} \text { Best Fit } \\
\text { mg }\end{array}$ \\
\hline Initial & 12.9 & 15.7074 & 0.0 & 12.9 & 15.5065 & 0.0 & 0.0 & 0.0 \\
\hline After 2 Hours & 12.8 & 15.6821 & 25.3 & 12.8 & 15.4863 & 20.2 & 22.8 & 22.8 \\
\hline After 4 Hours & 12.9 & 15.6550 & 27.1 & 12.9 & 15.4464 & 39.9 & 56.3 & 49.7 \\
\hline After 6 Hours & 12.8 & 15.6356 & 19.4 & 12.8 & 15.4212 & 25.2 & 78.5 & 78.6 \\
\hline Total & $:$ & & 71.8 & & & 85.3 & & \\
\hline
\end{tabular}

\begin{tabular}{|llcl|}
\hline Results & & & \\
${ }^{*}$ Best Fit Mass Loss & $:$ & $=$ & $10.4098{ }^{*}$ Hours ${ }^{\wedge} 1.12794$ \\
SAR Number & $:$ & 221.01 & Relative Rate of Mass/Volume loss at 2 hours \\
Departure & $:$ & $6 \%$ & Relative Rate of Change in Mass/Volume loss at 2 hours \\
Lap Wear & $:$ & 0.01 & $\mathrm{~mm}$ \\
\hline
\end{tabular}

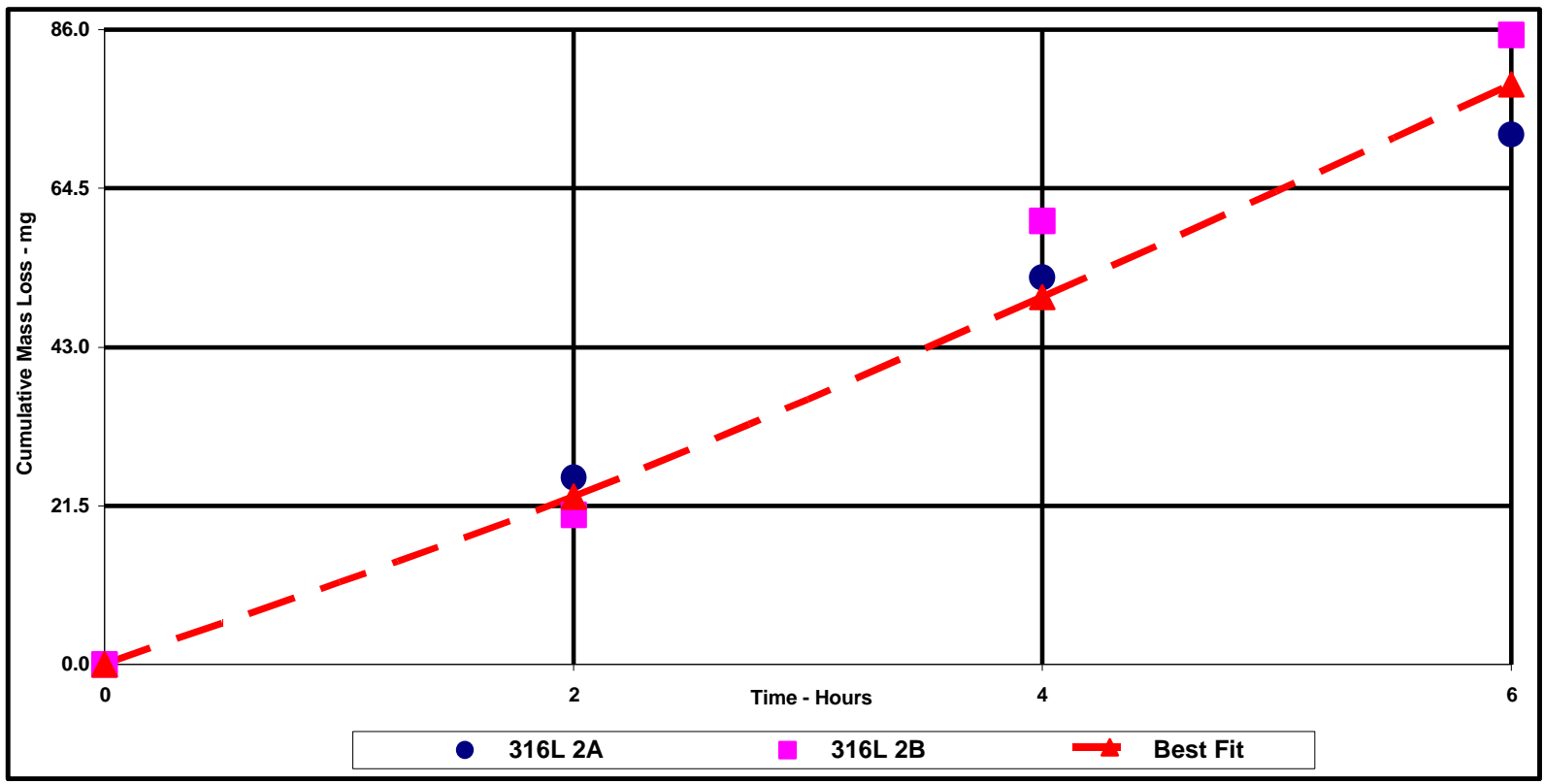


WSRC-TR-2002-00062, Rev. 0

SRT-RPP-2002-00022, Rev. 0

3 - Sr/Tru Slurry Test Results S-1028(304L SS) and S-1029(316L SS)
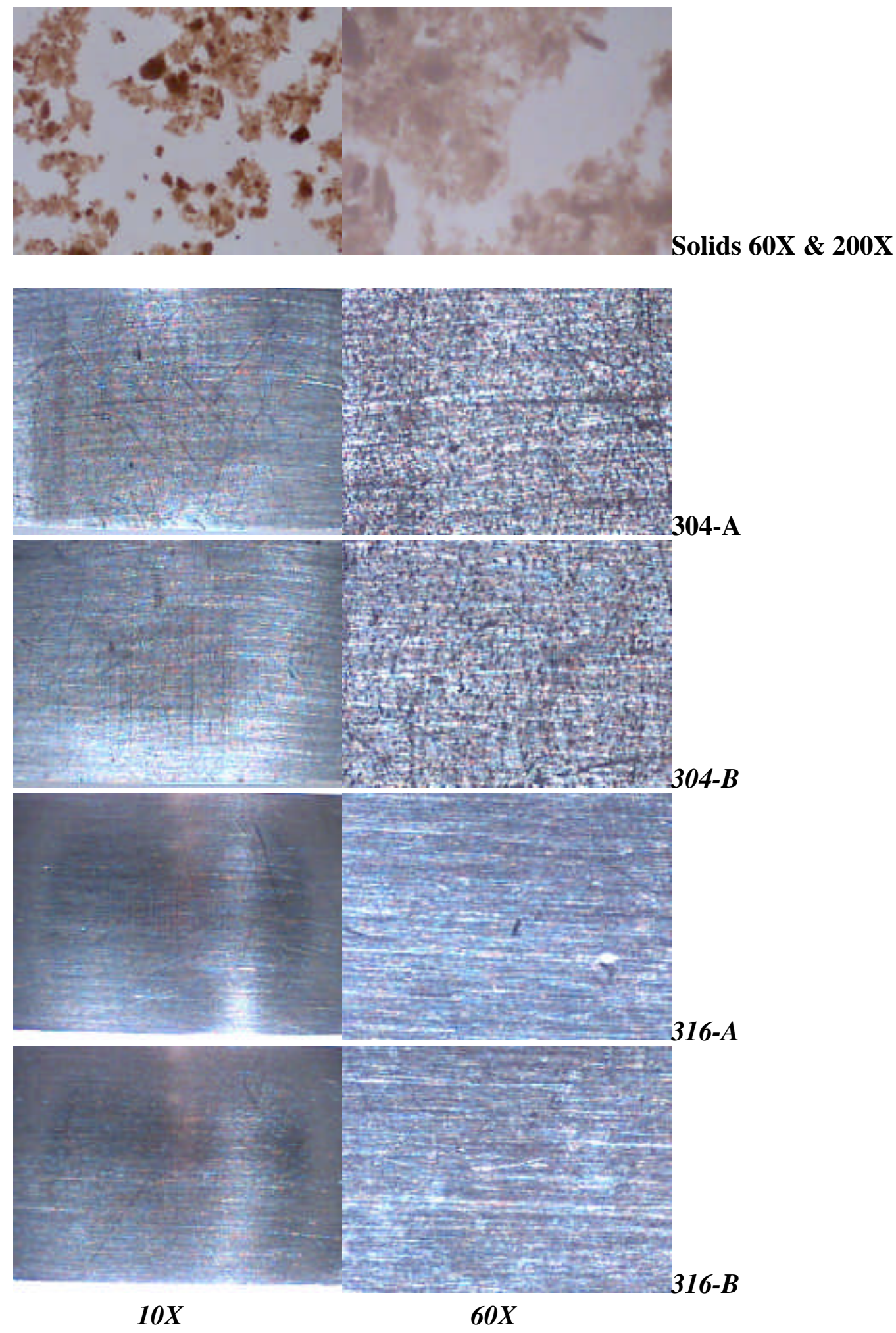
WSRC-TR-2002-00062, Rev. 0

SRT-RPP-2002-00022, Rev. 0

\section{ASTM G75 Slurry Abrasivity Determination} By Miller Number System

\begin{tabular}{|c|c|c|c|c|c|c|c|c|}
\hline \multicolumn{9}{|l|}{ Test } \\
\hline Number & \multicolumn{8}{|l|}{ : S-1028 } \\
\hline Type & \multicolumn{8}{|c|}{ : SAR Number } \\
\hline Date & \multicolumn{8}{|c|}{ : 5-Jan-2001 } \\
\hline \multicolumn{9}{|l|}{ Project } \\
\hline Description & \multicolumn{8}{|c|}{ : Westinghouse Savannah River - AB80166N } \\
\hline \multicolumn{9}{|c|}{ 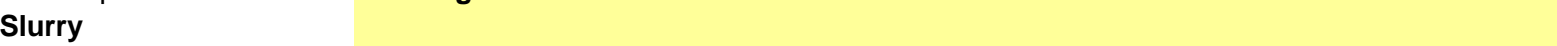 } \\
\hline Description & \multicolumn{8}{|c|}{ : Test 3 - Sr/TRU - 230ml 265 grams } \\
\hline Concentration & \multicolumn{8}{|c|}{ : $20 \%$ by Mass (as received) } \\
\hline Temperature & \multicolumn{8}{|c|}{$25 C+/-5$} \\
\hline \multicolumn{9}{|l|}{ Wear Specimen } \\
\hline Description & \multicolumn{8}{|c|}{ : 304L Stainless Steel } \\
\hline Specific Gravity & \multicolumn{8}{|c|}{ : 7.96} \\
\hline Hardness & \multicolumn{8}{|l|}{ : NA } \\
\hline \multicolumn{9}{|l|}{ Lap Material } \\
\hline Description & \multirow{2}{*}{\multicolumn{8}{|c|}{ : MIL-R-6855 CLASS 2 GRADE 80 NEOPRENE }} \\
\hline Hardness - Durometer & \multicolumn{6}{|c|}{$: 78-82$} & & \\
\hline Wear - mm & \multicolumn{8}{|l|}{$: 0.01$} \\
\hline \multirow[t]{2}{*}{ Wear Specimen } & \multicolumn{3}{|c|}{ 304L 3A } & \multicolumn{3}{|c|}{ 304L 3B } & \multicolumn{2}{|c|}{ Cumm Loss } \\
\hline & $\mathrm{pH}$ & $\begin{array}{c}\text { Mass } \\
\mathrm{g}\end{array}$ & $\begin{array}{c}\text { Loss } \\
\mathrm{mg}\end{array}$ & $\mathrm{pH}$ & $\begin{array}{c}\text { Mass } \\
\mathrm{g}\end{array}$ & $\begin{array}{c}\text { Loss } \\
\text { mg }\end{array}$ & $\begin{array}{c}\text { Ave } \\
\text { mg }\end{array}$ & $\begin{array}{c}{ }^{*} \text { Best Fit } \\
\text { mg }\end{array}$ \\
\hline \multirow{5}{*}{$\begin{array}{l}\text { Initial } \\
\text { After } 2 \text { Hours } \\
\text { After } 4 \text { Hours } \\
\text { After } 6 \text { Hours } \\
\text { Total }\end{array}$} & NA & 15.9650 & 0.0 & NA & 15.8995 & 0.0 & 0.0 & 0.0 \\
\hline & NA & 15.9635 & 1.5 & NA & 15.8978 & 1.7 & 1.6 & 1.6 \\
\hline & NA & 15.9623 & 1.2 & NA & 15.8972 & 0.6 & 2.5 & 2.6 \\
\hline & NA & 15.9613 & 1.0 & NA & 15.8962 & 1.0 & 3.5 & 3.5 \\
\hline & $:$ & & 3.7 & & & 3.3 & & \\
\hline
\end{tabular}

\begin{tabular}{|c|c|c|c|}
\hline \multicolumn{4}{|l|}{ Results } \\
\hline SAR Number & : & 9.90 & Relative Rate of Mass/Volume loss at 2 hours \\
\hline Departure & : & $-14 \%$ & Relative Rate of Change in Mass/Volume loss at 2 hours \\
\hline Lap Wear & : & 0.01 & mm \\
\hline
\end{tabular}

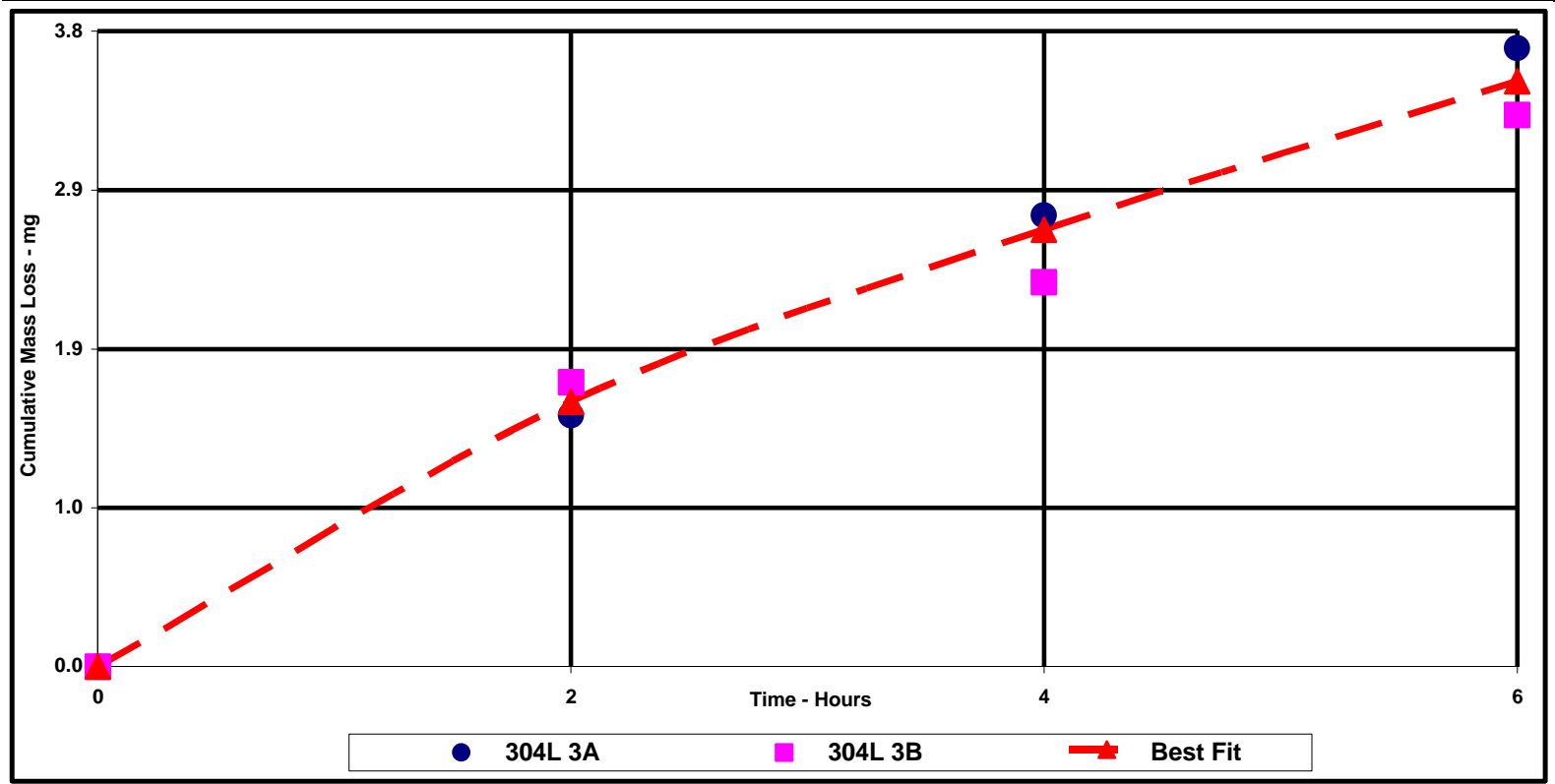


WSRC-TR-2002-00062, Rev. 0

SRT-RPP-2002-00022, Rev. 0

\section{ASTM G75 Slurry Abrasivity Determination By Miller Number System}

\begin{tabular}{|c|c|c|c|c|c|c|c|c|}
\hline \multicolumn{9}{|l|}{ Test } \\
\hline Number & \multicolumn{8}{|l|}{ : S-1029 } \\
\hline Type & \multicolumn{8}{|c|}{ : SAR Number } \\
\hline Date & \multicolumn{8}{|c|}{ : 5-Jan-2001 } \\
\hline \multicolumn{9}{|l|}{ Project } \\
\hline Description & \multicolumn{8}{|c|}{ : Westinghouse Savannah River - AB80166N } \\
\hline \multicolumn{9}{|l|}{ Slurry } \\
\hline Description & \multicolumn{8}{|c|}{ : Test 3 - Sr/TRU - $230 \mathrm{ml} \sim 265$ grams as received } \\
\hline Concentration & \multicolumn{8}{|c|}{ : $20 \%$ by Mass 9as received) } \\
\hline Temperature & \multicolumn{8}{|c|}{$: 25 C+/-5$} \\
\hline \multicolumn{9}{|l|}{ Wear Specimen } \\
\hline Description & \multicolumn{8}{|c|}{ : 316L Stainless Steel } \\
\hline Specific Gravity & \multicolumn{8}{|c|}{$: 8.00$} \\
\hline Hardness & \multicolumn{8}{|l|}{ : NA } \\
\hline \multicolumn{9}{|l|}{ Lap Material } \\
\hline Description & \multicolumn{8}{|c|}{ : MIL-R-6855 CLASS 2 GRADE 80 NEOPRENE } \\
\hline Hardness - Durometer & \multicolumn{8}{|c|}{ : 78-82 } \\
\hline Wear - mm & \multicolumn{8}{|l|}{$: 0.01$} \\
\hline \multirow[t]{2}{*}{ Wear Specimen } & \multicolumn{3}{|c|}{ 316L 3A } & \multicolumn{3}{|c|}{ 316L 3B } & \multicolumn{2}{|c|}{ Cumm Loss } \\
\hline & $\mathrm{pH}$ & $\begin{array}{c}\text { Mass } \\
\mathrm{g}\end{array}$ & $\begin{array}{c}\text { Loss } \\
\text { mg }\end{array}$ & $\mathrm{pH}$ & $\begin{array}{c}\text { Mass } \\
\mathrm{g}\end{array}$ & $\begin{array}{c}\text { Loss } \\
\mathrm{mg}\end{array}$ & $\begin{array}{l}\text { Ave } \\
\text { mg }\end{array}$ & $\begin{array}{c}{ }^{*} \text { Best Fit } \\
\text { mg }\end{array}$ \\
\hline Initial & NA & 15.8613 & 0.0 & NA & 15.8795 & 0.0 & 0.0 & 0.0 \\
\hline After 2 Hours & NA & 15.8602 & 1.1 & NA & 15.8787 & 0.8 & 0.9 & 0.9 \\
\hline After 4 Hours & NA & 15.8591 & 1.1 & NA & 15.8780 & 0.7 & 1.9 & 2.0 \\
\hline After 6 Hours & NA & 15.8578 & 1.3 & NA & 15.8768 & 1.2 & 3.1 & 3.1 \\
\hline Total & $:$ & & 3.5 & & & 2.7 & & \\
\hline
\end{tabular}

\begin{tabular}{|llcl|}
\hline Results & & & \multicolumn{1}{c|}{$0.4477{ }^{*}$ Hours^ 1.08000} \\
${ }^{\star}$ Best Fit Mass Loss & $:$ & $=$ & Relative Rate of Mass/Volume loss at 2 hours \\
SAR Number & $:$ & 8.80 & Relat 2 hours \\
Departure & $:$ & $4 \%$ & Relative Rate of Change in Mass/Volume loss at \\
Lap Wear & $:$ & 0.01 & $\mathrm{~mm}$ \\
\hline
\end{tabular}

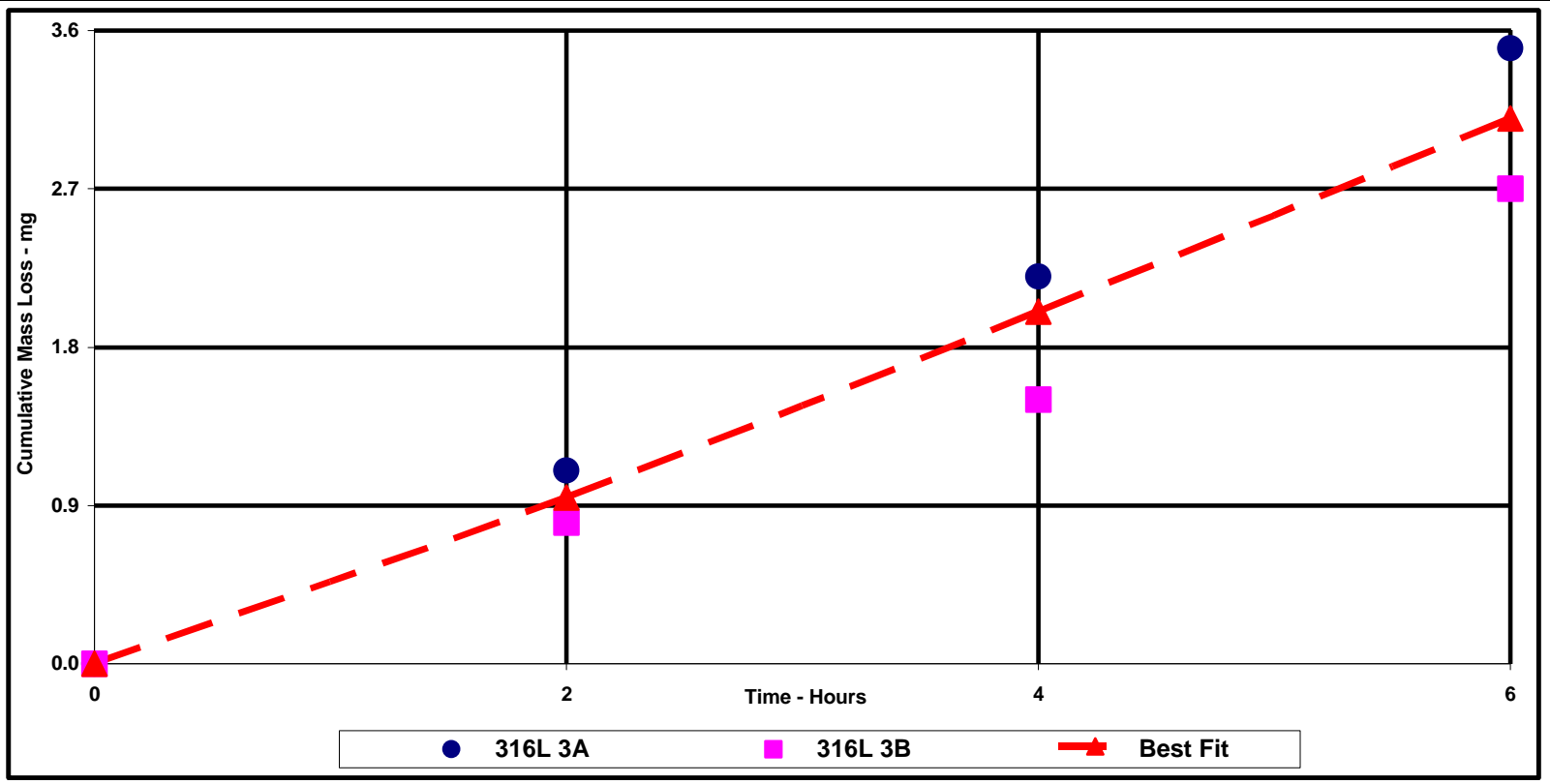


RPP-WTP Slurry Wear Evaluation: Slurry Abrasivity

WSRC-TR-2002-00062, Rev. 0

SRT-RPP-2002-00022, Rev. 0

4 - HLW Leached Slurry Test Results S-1030(304L SS) and S-1031(316L SS)
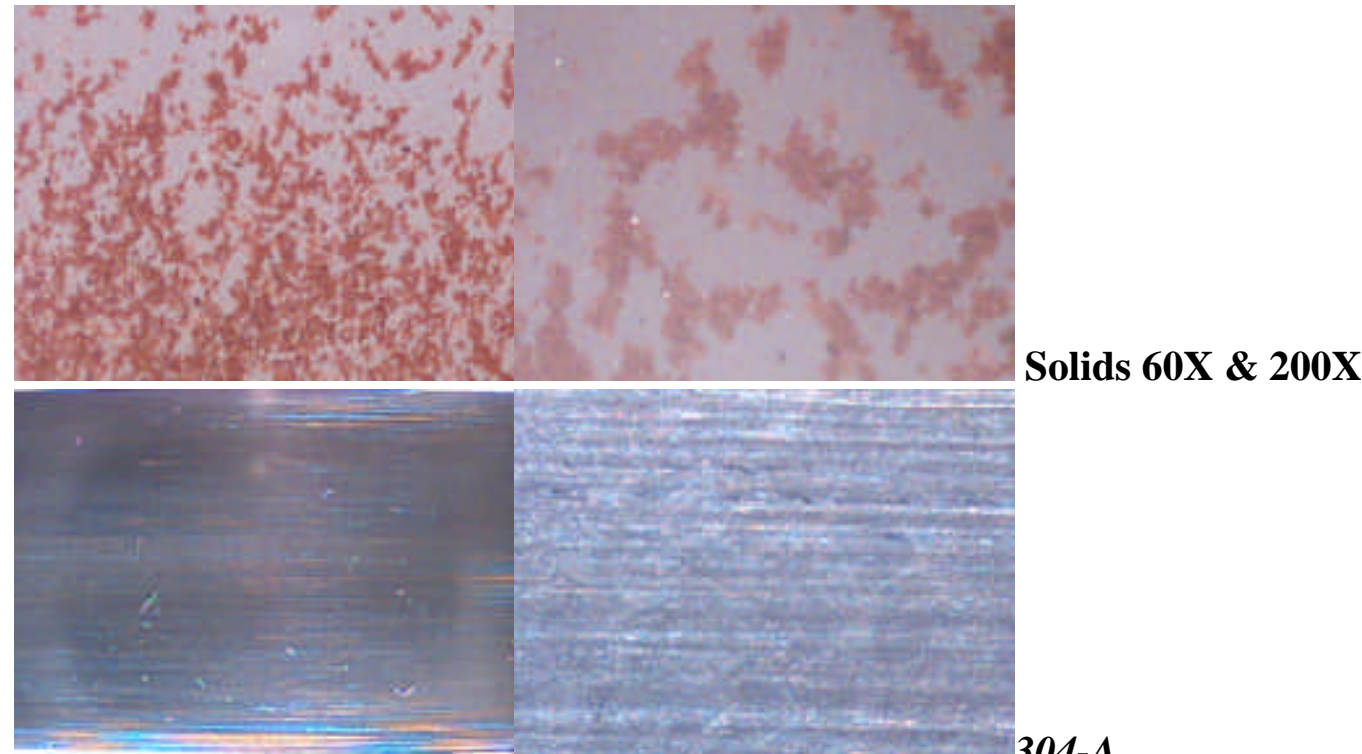

304-A
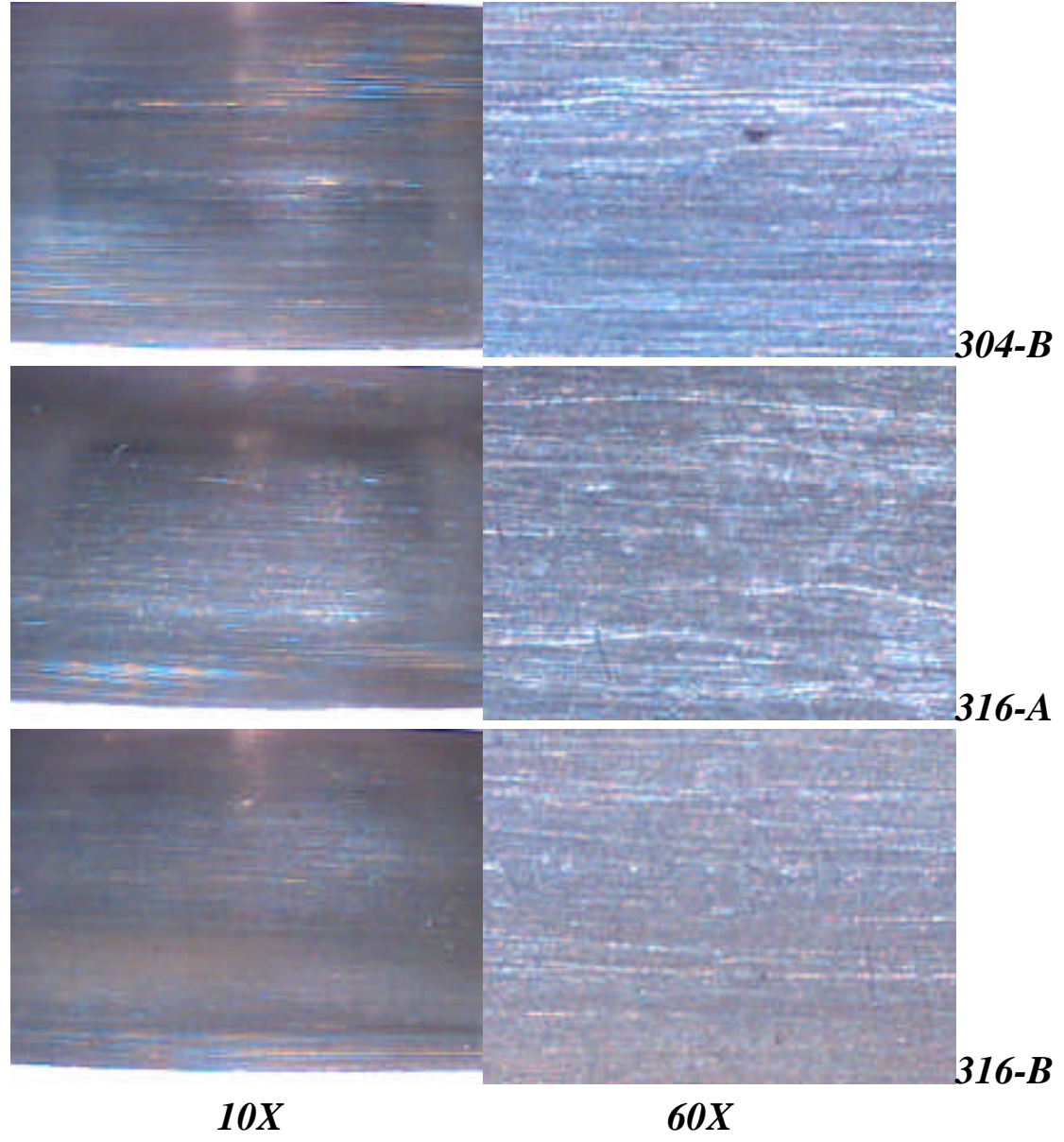
WSRC-TR-2002-00062, Rev. 0

SRT-RPP-2002-00022, Rev. 0

\section{ASTM G75 Slurry Abrasivity Determination \\ By Miller Number System}

\begin{tabular}{|c|c|c|c|c|c|c|c|c|}
\hline \multicolumn{9}{|l|}{ Test } \\
\hline Number & \multicolumn{8}{|c|}{ : S-1030 } \\
\hline Type & \multicolumn{8}{|c|}{ : SAR Number } \\
\hline Date & \multicolumn{8}{|c|}{ : 24-May-2001 } \\
\hline \multicolumn{9}{|l|}{ Project } \\
\hline Description & \multicolumn{8}{|c|}{ : Westinghouse Savannah River - AB80166N } \\
\hline \multicolumn{9}{|l|}{ Slurry } \\
\hline Description & \multicolumn{8}{|c|}{ : Test 4 - HLW Leached - 302 \& 295 grams as received } \\
\hline Concentration & \multicolumn{8}{|c|}{ : $20 \%$ by Mass (as received) } \\
\hline Temperature & \multicolumn{8}{|c|}{$: 85 C+/-5$} \\
\hline \multicolumn{9}{|l|}{ Wear Specimen } \\
\hline Description & \multicolumn{8}{|c|}{ : 304L Stainless Steel } \\
\hline Specific Gravity & \multicolumn{8}{|c|}{$: 7.96$} \\
\hline Hardness & \multicolumn{8}{|l|}{ : NA } \\
\hline \multicolumn{9}{|l|}{ Lap Material } \\
\hline Description & \multicolumn{8}{|c|}{ : MIL-R-6855 CLASS 2 GRADE 80 NEOPRENE } \\
\hline Hardness - Durometer & \multicolumn{8}{|c|}{$: 78-82$} \\
\hline Wear - mm & \multicolumn{8}{|l|}{$: 0.01$} \\
\hline \multirow[t]{2}{*}{ Wear Specimen } & \multicolumn{3}{|c|}{ 304L 4A } & \multicolumn{3}{|c|}{ 304L 4B } & \multicolumn{2}{|c|}{ Cumm Loss } \\
\hline & $\mathrm{pH}$ & $\begin{array}{c}\text { Mass } \\
\mathrm{g}\end{array}$ & $\begin{array}{c}\text { Loss } \\
\mathrm{mg}\end{array}$ & $\mathrm{pH}$ & $\begin{array}{c}\text { Mass } \\
\mathrm{g}\end{array}$ & $\begin{array}{c}\text { Loss } \\
\text { mg }\end{array}$ & $\begin{array}{l}\text { Ave } \\
\text { mg }\end{array}$ & $\begin{array}{c}{ }^{*} \text { Best Fit } \\
\text { mg }\end{array}$ \\
\hline \multirow{5}{*}{$\begin{array}{l}\text { Initial } \\
\text { After } 2 \text { Hours } \\
\text { After } 4 \text { Hours } \\
\text { After } 6 \text { Hours } \\
\text { Total }\end{array}$} & 11.8 & 15.8385 & 0.0 & 11.8 & 15.8731 & 0.0 & 0.0 & 0.0 \\
\hline & 11.8 & 15.8261 & 12.4 & 11.8 & 15.8622 & 10.9 & 11.7 & 12.7 \\
\hline & 11.7 & 15.8122 & 13.9 & 11.7 & 15.8453 & 16.9 & 27.1 & 24.4 \\
\hline & 11.7 & 15.8046 & 7.6 & 11.7 & 15.8356 & 9.7 & 35.7 & 35.7 \\
\hline & \multicolumn{3}{|r|}{33.9} & \multicolumn{3}{|r|}{37.5} & & \\
\hline
\end{tabular}

\begin{tabular}{|llcl|}
\hline Results & & & \\
${ }^{*}$ Best Fit Mass Loss & $:$ & $=$ & $6.6301{ }^{*}$ Hours^ 0.93960 \\
SAR Number & $:$ & 103.43 & Relative Rate of Mass/Volume loss at 2 hours \\
Departure & $:$ & $-3 \%$ & Relative Rate of Change in Mass/Volume loss at 2 hours \\
Lap Wear & $:$ & 0.01 & $\mathrm{~mm}$ \\
\hline
\end{tabular}

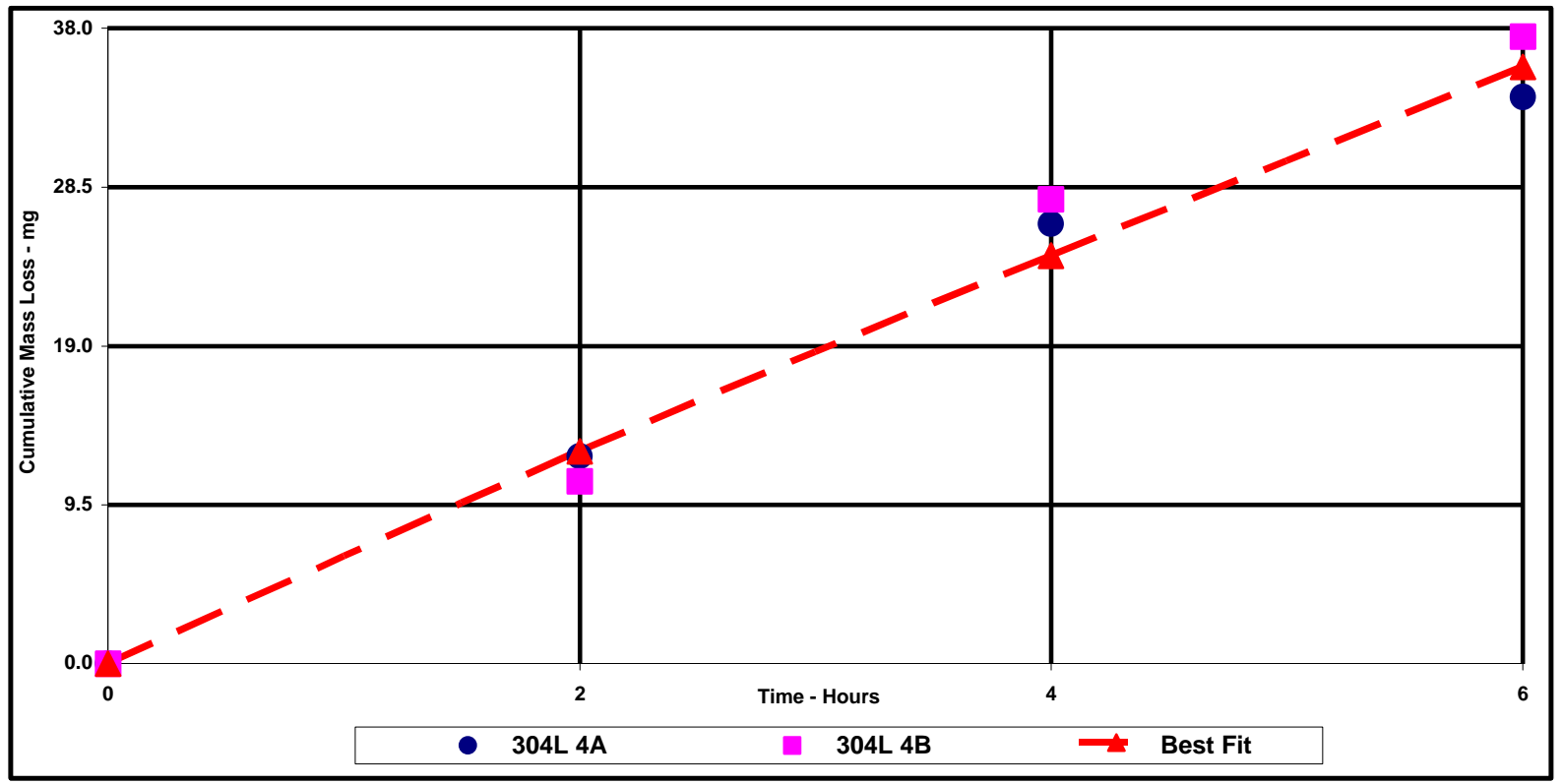


WSRC-TR-2002-00062, Rev. 0

SRT-RPP-2002-00022, Rev. 0

\section{ASTM G75 Slurry Abrasivity Determination By Miller Number System}

\begin{tabular}{|c|c|c|c|c|c|c|c|c|}
\hline \multicolumn{9}{|l|}{ Test } \\
\hline Number & \multicolumn{8}{|l|}{ : S-1031 } \\
\hline Type & \multicolumn{8}{|c|}{ : SAR Number } \\
\hline Date & \multicolumn{8}{|c|}{ : 24-May-2001 } \\
\hline \multicolumn{9}{|l|}{ Project } \\
\hline Description & \multicolumn{8}{|c|}{ : Westinghouse Savannah River - AB80166N } \\
\hline \multicolumn{9}{|l|}{ Slurry } \\
\hline Description & \multicolumn{8}{|c|}{ : Test 4 - HLW Leached - $306 \& 305$ grams as received } \\
\hline Concentration & \multicolumn{8}{|c|}{ : $20 \%$ by Mass (as received) } \\
\hline Temperature & \multicolumn{8}{|c|}{$: 85 C+/-5$} \\
\hline \multicolumn{9}{|l|}{ Wear Specimen } \\
\hline Description & \multicolumn{8}{|c|}{ : 316L Stainless Steel } \\
\hline Specific Gravity & \multicolumn{8}{|c|}{$: 8.00$} \\
\hline Hardness & \multicolumn{8}{|l|}{ : NA } \\
\hline \multicolumn{9}{|l|}{ Lap Material } \\
\hline Description & \multicolumn{8}{|c|}{ : MIL-R-6855 CLASS 2 GRADE 80 NEOPRENE } \\
\hline Hardness - Durometer & \multicolumn{8}{|c|}{$: 78-82$} \\
\hline Wear - mm & \multicolumn{8}{|l|}{$: 0.01$} \\
\hline \multirow[t]{2}{*}{ Wear Specimen } & \multicolumn{3}{|c|}{ 316L 4A } & \multicolumn{3}{|c|}{ 316L 4B } & \multicolumn{2}{|c|}{ Cumm Loss } \\
\hline & $\mathrm{pH}$ & $\begin{array}{c}\text { Mass } \\
\mathrm{g}\end{array}$ & $\begin{array}{c}\text { Loss } \\
\text { mg }\end{array}$ & $\mathrm{pH}$ & $\begin{array}{c}\text { Mass } \\
\mathrm{g}\end{array}$ & $\begin{array}{c}\text { Loss } \\
\text { mg }\end{array}$ & $\begin{array}{l}\text { Ave } \\
\text { mg }\end{array}$ & $\begin{array}{c}{ }^{*} \text { Best Fit } \\
\text { mg }\end{array}$ \\
\hline Initial & 11.8 & 15.8348 & 0.0 & 11.8 & 15.7740 & 0.0 & 0.0 & 0.0 \\
\hline After 2 Hours & 11.8 & 15.8228 & 12.0 & 11.8 & 15.7609 & 13.1 & 12.5 & 12.5 \\
\hline After 4 Hours & 11.7 & 15.8124 & 10.4 & 11.7 & 15.7487 & 12.2 & 23.8 & 23.7 \\
\hline After 6 Hours & 11.7 & 15.8043 & 8.1 & 11.7 & 15.7356 & 13.1 & 34.4 & 34.4 \\
\hline Total & $:$ & & 30.5 & & & 38.4 & & \\
\hline
\end{tabular}

\begin{tabular}{|llcl|}
\hline Results & & & \\
${ }^{*}$ Best Fit Mass Loss & $:$ & $=$ & \multicolumn{1}{c|}{$6.6368{ }^{*}$ Hours^ 0.91912} \\
SAR Number & $:$ & 99.35 & Relative Rate of Mass/Volume loss at 2 hours \\
Departure & $:$ & $-4 \%$ & Relative Rate of Change in Mass/Volume loss at 2 hours \\
Lap Wear & $:$ & 0.01 & $\mathrm{~mm}$ \\
\hline
\end{tabular}

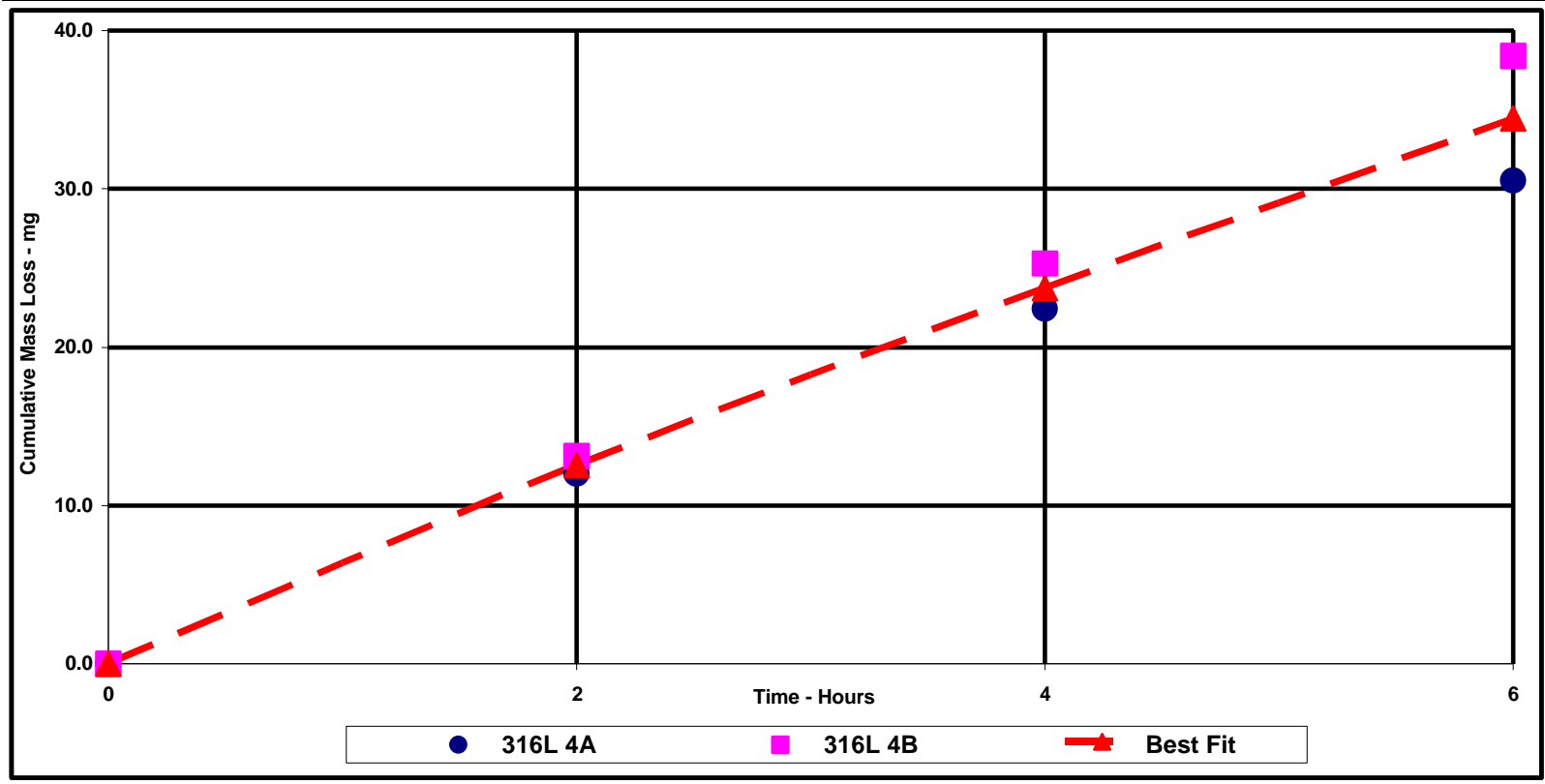


RPP-WTP Slurry Wear Evaluation: Slurry Abrasivity

WSRC-TR-2002-00062, Rev. 0

SRT-RPP-2002-00022, Rev. 0

5 - HLWwSBS Leached Slurry Test Results S-1032(304L SS) and S-1033(316L SS)
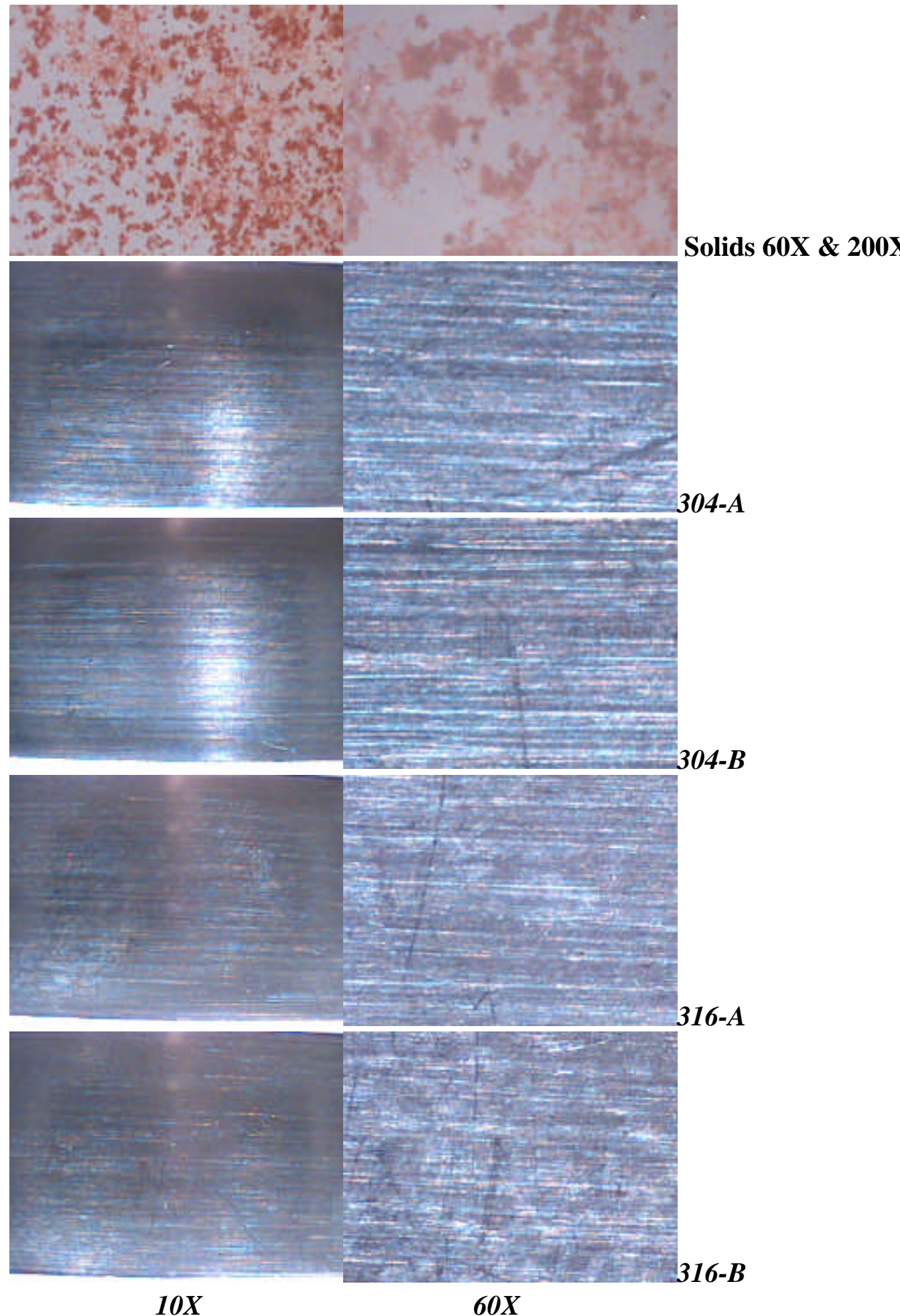
WSRC-TR-2002-00062, Rev. 0

SRT-RPP-2002-00022, Rev. 0

\section{ASTM G75 Slurry Abrasivity Determination \\ By Miller Number System}

\begin{tabular}{|c|c|c|c|c|c|c|c|c|}
\hline \multicolumn{9}{|l|}{ Test } \\
\hline Number & \multicolumn{8}{|l|}{ : S-1032 } \\
\hline Type & \multicolumn{8}{|c|}{ : SAR Number } \\
\hline Date & \multicolumn{8}{|c|}{ : 1-Nov-2001 } \\
\hline \multicolumn{9}{|l|}{ Project } \\
\hline Description & \multicolumn{8}{|c|}{ : Westinghouse Savannah River - AB80166N } \\
\hline \multicolumn{9}{|c|}{ 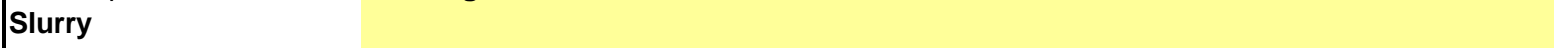 } \\
\hline Description & \multicolumn{8}{|c|}{ : Test 5 - HLWwSBS Leached - 302 \& 298 grams as received } \\
\hline Concentration & \multicolumn{8}{|c|}{ : $20 \%$ by Mass (as received) } \\
\hline Temperature & \multicolumn{8}{|c|}{$: 25 C+/-5 C$} \\
\hline \multicolumn{9}{|l|}{ Wear Specimen } \\
\hline Description & \multicolumn{8}{|c|}{ : 304L Stainless Steel } \\
\hline Specific Gravity & \multicolumn{8}{|c|}{ : 7.96} \\
\hline Hardness & \multicolumn{8}{|l|}{ : NA } \\
\hline \multicolumn{9}{|l|}{ Lap Material } \\
\hline Description & \multicolumn{8}{|c|}{ : MIL-R-6855 CLASS 2 GRADE 80 NEOPRENE } \\
\hline Hardness - Durometer & \multicolumn{8}{|c|}{$: 78-82$} \\
\hline Wear - mm & \multicolumn{8}{|l|}{$: 0.01$} \\
\hline \multirow[t]{2}{*}{ Wear Specimen } & \multicolumn{3}{|c|}{ 304L 5A } & \multicolumn{3}{|c|}{ 304L 5B } & \multicolumn{2}{|c|}{ Cumm Loss } \\
\hline & $\mathrm{pH}$ & $\begin{array}{c}\text { Mass } \\
\mathrm{g}\end{array}$ & $\begin{array}{c}\text { Loss } \\
\mathrm{mg}\end{array}$ & $\mathrm{pH}$ & $\begin{array}{c}\text { Mass } \\
\mathrm{g}\end{array}$ & $\begin{array}{c}\text { Loss } \\
\mathrm{mg}\end{array}$ & $\begin{array}{c}\text { Ave } \\
\text { mg }\end{array}$ & $\begin{array}{c}{ }^{*} \text { Best Fit } \\
\text { mg }\end{array}$ \\
\hline Initial & 12.6 & 15.8231 & 0.0 & 12.6 & 15.9059 & 0.0 & 0.0 & 0.0 \\
\hline After 2 Hours & 12.5 & 15.8028 & 20.3 & 12.5 & 15.8763 & 29.6 & 25.0 & 25.6 \\
\hline After 4 Hours & 12.5 & 15.7737 & 29.1 & 12.5 & 15.8495 & 26.8 & 52.9 & 48.7 \\
\hline After 6 Hours & 12.4 & 15.7523 & 21.4 & 12.4 & 15.8348 & 14.7 & 71.0 & 71.0 \\
\hline Total & $:$ & & 70.8 & & & 71.1 & & \\
\hline
\end{tabular}

\begin{tabular}{|llcl|}
\hline Results & & & \\
${ }^{*}$ Best Fit Mass Loss & $:$ & $=$ & $13.4570{ }^{*}$ Hours ${ }^{\wedge} 0.92785$ \\
SAR Number & $:$ & 205.61 & Relative Rate of Mass/Volume loss at 2 hours \\
Departure & $:$ & $-4 \%$ & Relative Rate of Change in Mass/Volume loss at 2 hours \\
Lap Wear & $:$ & 0.01 & $\mathrm{~mm}$ \\
\hline
\end{tabular}

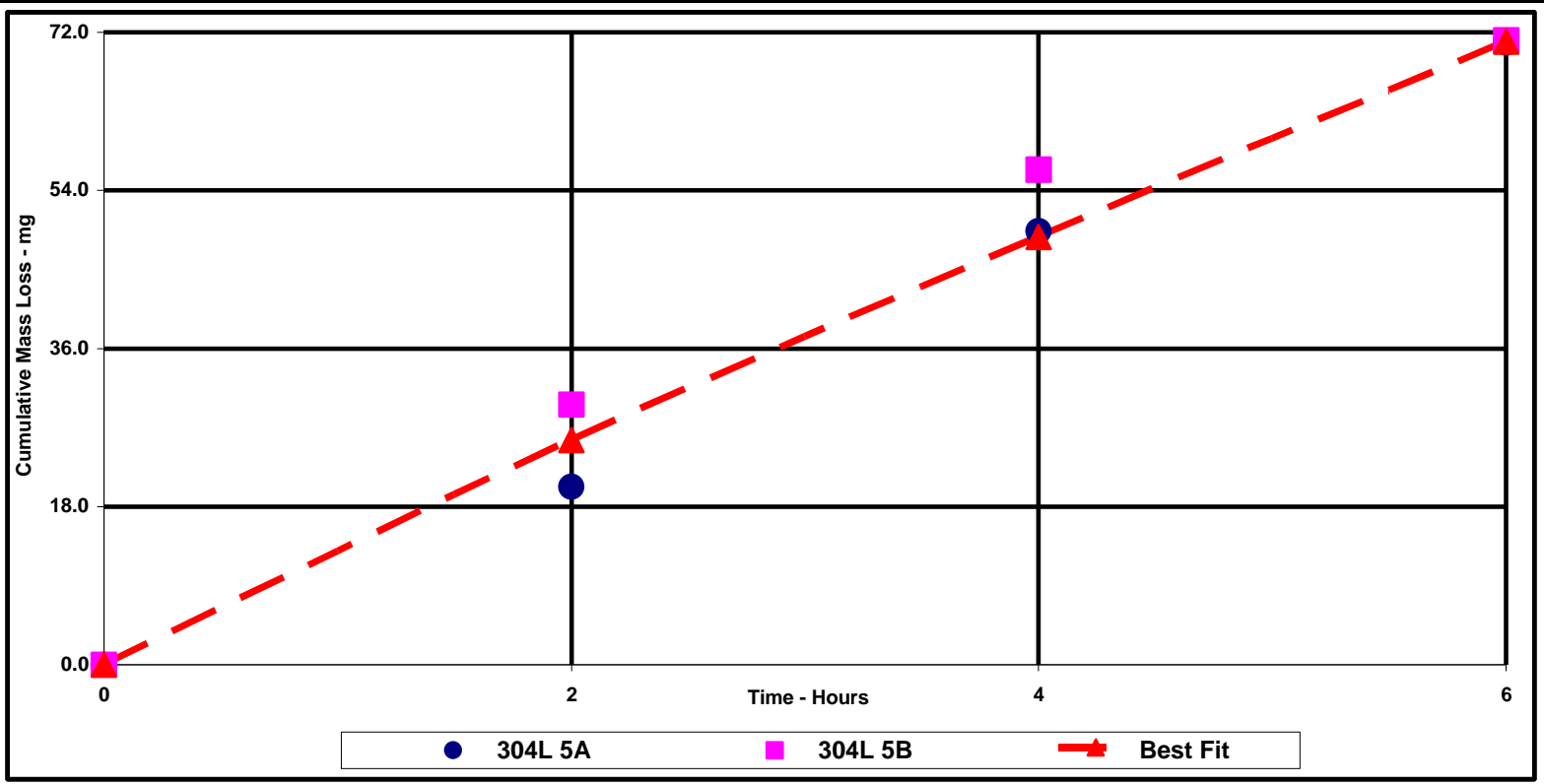


WSRC-TR-2002-00062, Rev. 0

SRT-RPP-2002-00022, Rev. 0

\section{ASTM G75 Slurry Abrasivity Determination By Miller Number System}

\begin{tabular}{|c|c|c|c|c|c|c|c|c|}
\hline \multicolumn{9}{|l|}{ Test } \\
\hline Number & \multicolumn{8}{|l|}{ : S-1033 } \\
\hline Type & \multicolumn{8}{|c|}{ : SAR Number } \\
\hline Date & \multicolumn{8}{|c|}{ : 1-Nov-2001 } \\
\hline \multicolumn{9}{|l|}{ Project } \\
\hline Description & \multicolumn{8}{|c|}{ : Westinghouse Savannah River - AB80166N } \\
\hline \multicolumn{9}{|l|}{ Slurry } \\
\hline Description & \multirow{2}{*}{\multicolumn{8}{|c|}{$\begin{array}{l}\text { : Test } 5 \text { - HLWwSBS Leached }-293 \& 307 \text { grams as Received } \\
\text { : } 20 \% \text { bv Mass (as received the } 307 \text { a batch had sianificant more solids) }\end{array}$}} \\
\hline Concentration & & & & & & & & \\
\hline Temperature & \multicolumn{8}{|c|}{$: 25 C+/-5$} \\
\hline \multicolumn{9}{|l|}{ Wear Specimen } \\
\hline Description & \multicolumn{8}{|c|}{ : 316L Stainless Steel } \\
\hline Specific Gravity & \multicolumn{8}{|c|}{$: 8.00$} \\
\hline Hardness & \multicolumn{8}{|l|}{ : NA } \\
\hline \multicolumn{9}{|l|}{ Lap Material } \\
\hline Description & \multicolumn{8}{|c|}{ : MIL-R-6855 CLASS 2 GRADE 80 NEOPRENE } \\
\hline Hardness - Durometer & \multicolumn{8}{|c|}{ : 78-82 } \\
\hline Wear - mm & \multicolumn{8}{|l|}{$: 0.01$} \\
\hline \multirow[t]{2}{*}{ Wear Specimen } & \multicolumn{3}{|c|}{ 316L 5A } & \multicolumn{3}{|c|}{ 316L 5B } & \multicolumn{2}{|c|}{ Cumm Loss } \\
\hline & $\mathrm{pH}$ & $\begin{array}{c}\text { Mass } \\
\mathrm{g}\end{array}$ & $\begin{array}{c}\text { Loss } \\
\text { mg }\end{array}$ & $\mathrm{pH}$ & $\begin{array}{c}\text { Mass } \\
\mathrm{g}\end{array}$ & $\begin{array}{c}\text { Loss } \\
\text { mg }\end{array}$ & $\begin{array}{l}\text { Ave } \\
\text { mg }\end{array}$ & $\begin{array}{c}{ }^{*} \text { Best Fit } \\
\text { mg }\end{array}$ \\
\hline Initial & 12.6 & 15.9283 & 0.0 & 12.6 & 15.8948 & 0.0 & 0.0 & 0.0 \\
\hline After 2 Hours & 12.5 & 15.8947 & 33.6 & 12.5 & 15.8310 & 63.8 & 48.7 & 48.6 \\
\hline After 4 Hours & 12.5 & 15.8673 & 27.4 & 12.5 & 15.7742 & 56.8 & 90.8 & 91.9 \\
\hline After 6 Hours & 12.4 & 15.8345 & 32.8 & 12.4 & 15.7218 & 52.4 & 133.4 & 133.4 \\
\hline Total & $:$ & & 93.8 & & & 173.0 & & \\
\hline
\end{tabular}

\begin{tabular}{|llcl|}
\hline Results & & & \\
${ }^{\star}$ Best Fit Mass Loss & $:$ & $=$ & $25.6765{ }^{*}$ Hours^ 0.91964 \\
SAR Number & $:$ & 384.71 & Relative Rate of Mass/Volume loss at 2 hours \\
Departure & $:$ & $-4 \%$ & Relative Rate of Change in Mass/Volume loss at 2 hours \\
Lap Wear & $:$ & 0.01 & $\mathrm{~mm}$ \\
\hline
\end{tabular}

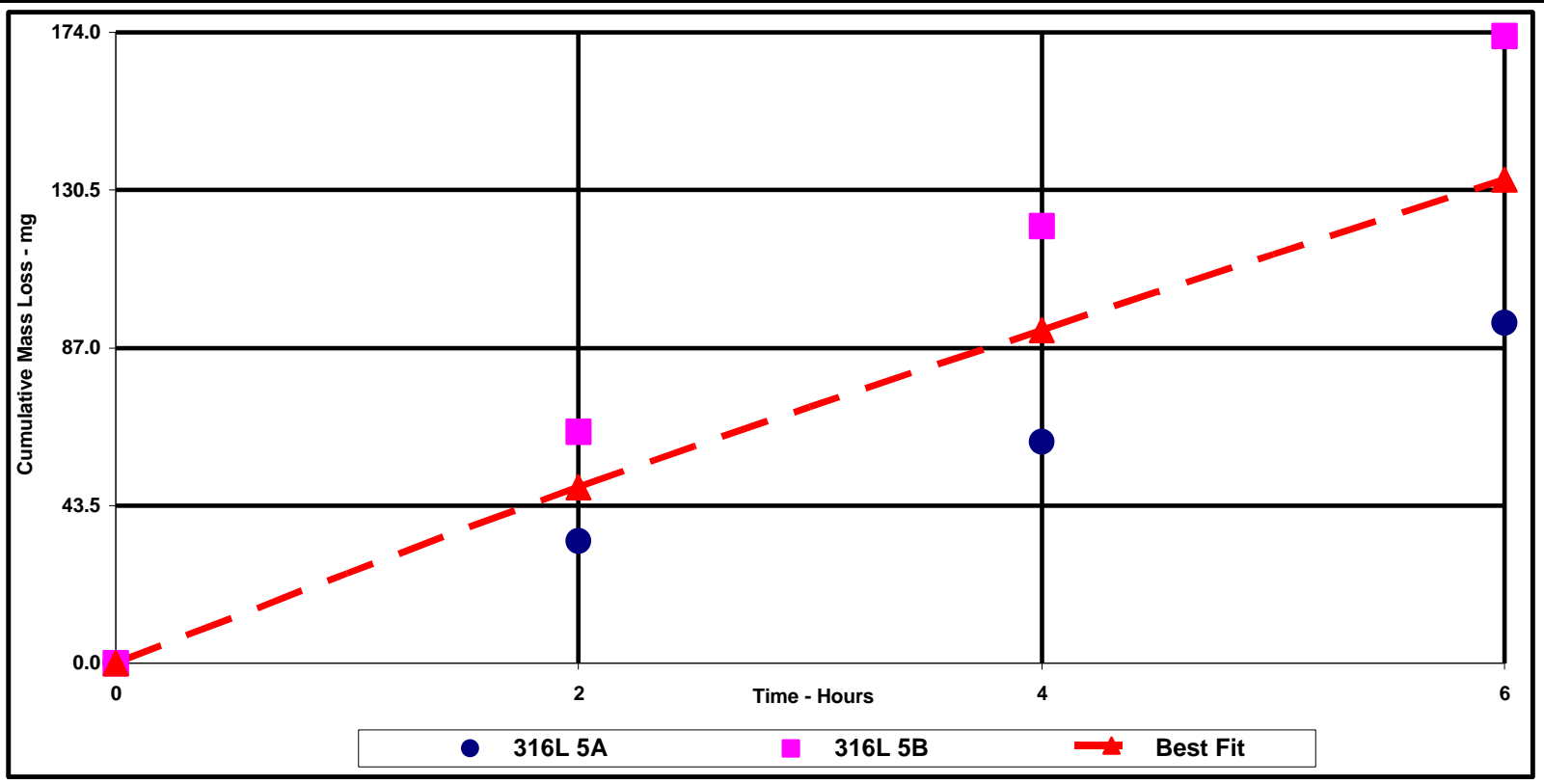


WSRC-TR-2002-00062, Rev. 0

SRT-RPP-2002-00022, Rev. 0

\section{ASTM G75 Slurry Abrasivity Determination By Miller Number System}

\begin{tabular}{|c|c|c|c|c|c|c|c|c|}
\hline \multicolumn{9}{|l|}{ Test } \\
\hline Number & \multicolumn{8}{|c|}{ : S-1033R } \\
\hline Type & \multicolumn{8}{|c|}{ : SAR Number } \\
\hline Date & \multicolumn{8}{|c|}{ : 23-Nov-2001 } \\
\hline \multicolumn{9}{|l|}{ Project } \\
\hline Description & \multicolumn{8}{|c|}{ : Westinghouse Savannah River - AB80166N } \\
\hline \multicolumn{9}{|l|}{ Slurry } \\
\hline Description & \multicolumn{8}{|c|}{ : Test 5R - HLWwSBS Leached - 302 \& 294 grams as Received } \\
\hline Concentration & \multicolumn{8}{|c|}{ : $20 \%$ by Mass (as received) } \\
\hline Temperature & \multicolumn{8}{|c|}{$: 25 C+/-5$} \\
\hline \multicolumn{9}{|l|}{ Wear Specimen } \\
\hline Description & \multicolumn{8}{|c|}{ : 316L Stainless Steel } \\
\hline Specific Gravity & \multicolumn{8}{|c|}{$: 8.00$} \\
\hline Hardness & \multicolumn{8}{|l|}{ : NA } \\
\hline \multicolumn{9}{|l|}{ Lap Material } \\
\hline Description & \multicolumn{8}{|c|}{ : MIL-R-6855 CLASS 2 GRADE 80 NEOPRENE } \\
\hline Hardness - Durometer & \multicolumn{8}{|c|}{$: 78-82$} \\
\hline Wear - mm & \multicolumn{8}{|l|}{$: 0.01$} \\
\hline \multirow[t]{2}{*}{ Wear Specimen } & \multicolumn{3}{|c|}{ 316L 5A } & \multicolumn{3}{|c|}{ 316L 5B } & \multicolumn{2}{|c|}{ Cumm Loss } \\
\hline & $\mathrm{pH}$ & $\begin{array}{c}\text { Mass } \\
\mathrm{g}\end{array}$ & $\begin{array}{c}\text { Loss } \\
\text { mg }\end{array}$ & $\mathrm{pH}$ & $\begin{array}{c}\text { Mass } \\
\mathrm{g}\end{array}$ & $\begin{array}{c}\text { Loss } \\
\mathrm{mg}\end{array}$ & $\begin{array}{l}\text { Ave } \\
\text { mg }\end{array}$ & $\begin{array}{c}{ }^{*} \text { Best Fit } \\
\text { mg }\end{array}$ \\
\hline \multirow{5}{*}{$\begin{array}{l}\text { Initial } \\
\text { After } 2 \text { Hours } \\
\text { After } 4 \text { Hours } \\
\text { After } 6 \text { Hours } \\
\text { Total }\end{array}$} & 13.4 & 15.6666 & 0.0 & 13.4 & 15.5562 & 0.0 & 0.0 & 0.0 \\
\hline & 13.5 & 15.6345 & 32.1 & 13.5 & 15.5287 & 27.5 & 29.8 & 29.8 \\
\hline & 13.4 & 15.5858 & 48.7 & 13.4 & 15.4910 & 37.7 & 73.0 & 63.4 \\
\hline & 13.6 & 15.5635 & 22.3 & 13.7 & 15.4620 & 29.0 & 98.7 & 98.6 \\
\hline & $:$ & & 103.1 & & & 94.2 & & \\
\hline
\end{tabular}

\begin{tabular}{|llcl|}
\hline Results & & & \\
${ }^{*}$ Best Fit Mass Loss & $:$ & $=$ & $14.0029{ }^{*}$ Hours^ 1.08959 \\
SAR Number & $:$ & 279.65 & Relative Rate of Mass/Volume loss at 2 hours \\
Departure & $:$ & $4 \%$ & Relative Rate of Change in Mass/Volume loss at 2 hours \\
Lap Wear & $:$ & 0.01 & $\mathrm{~mm}$ \\
\hline
\end{tabular}

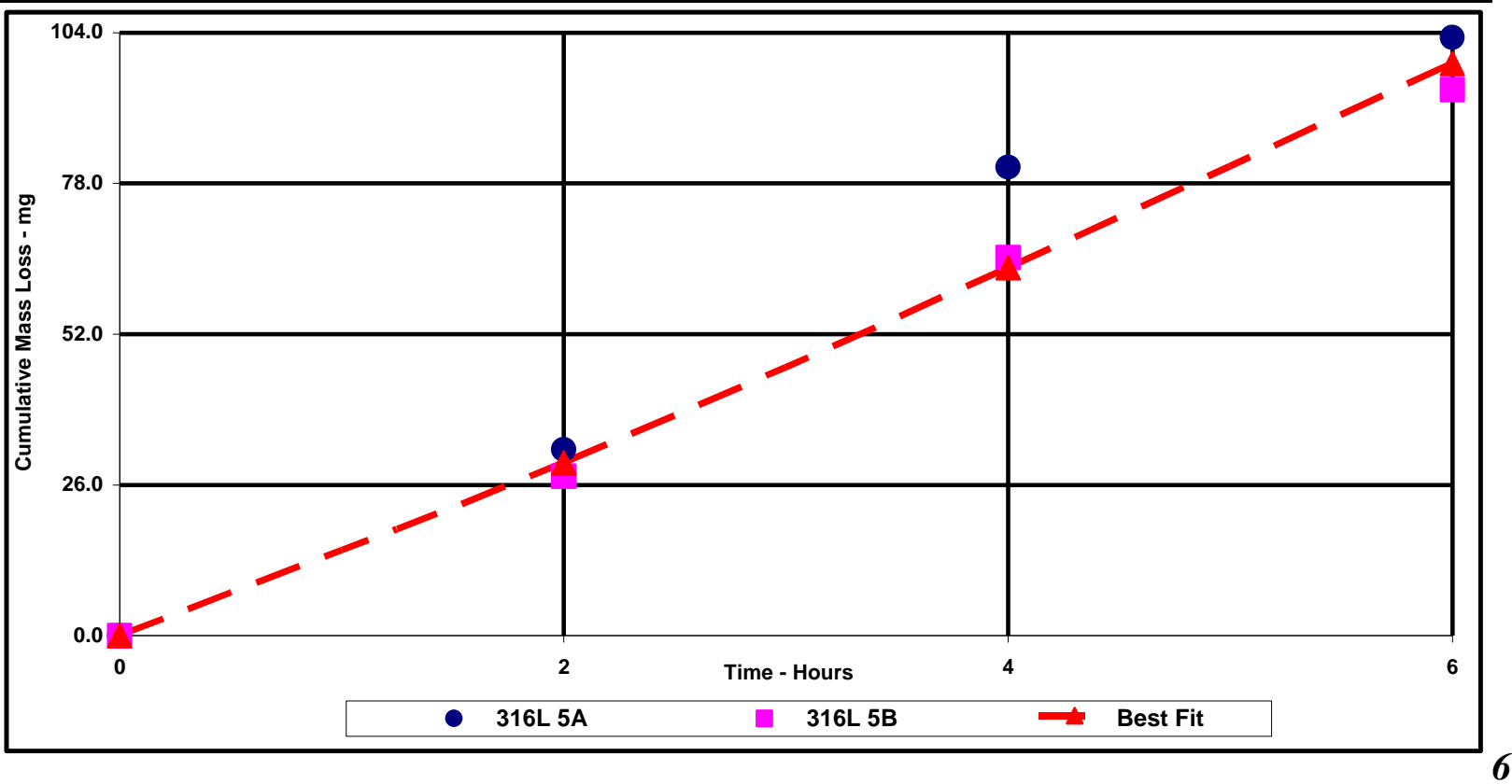


RPP-WTP Slurry Wear Evaluation: Slurry Abrasivity

WSRC-TR-2002-00062, Rev. 0

SRT-RPP-2002-00022, Rev. 0

6-HLW Washed Slurry Test Results S-1041(304L SS) and S-1042(316L SS

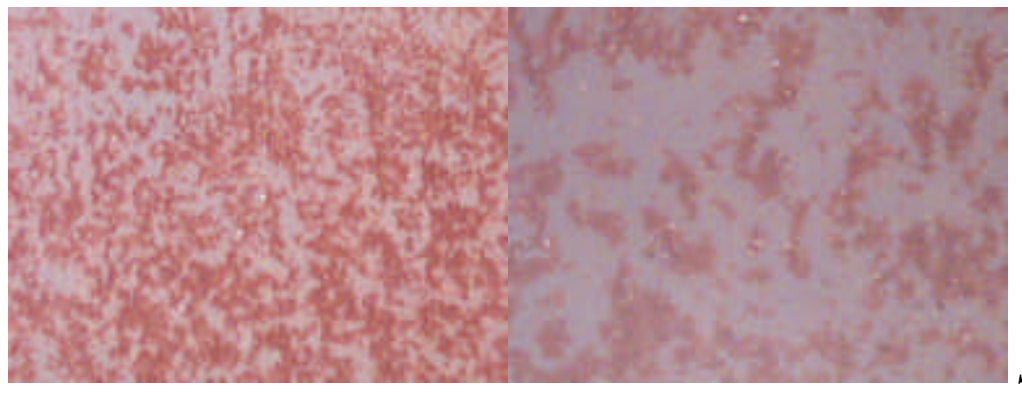

Solids 60X \& 200X
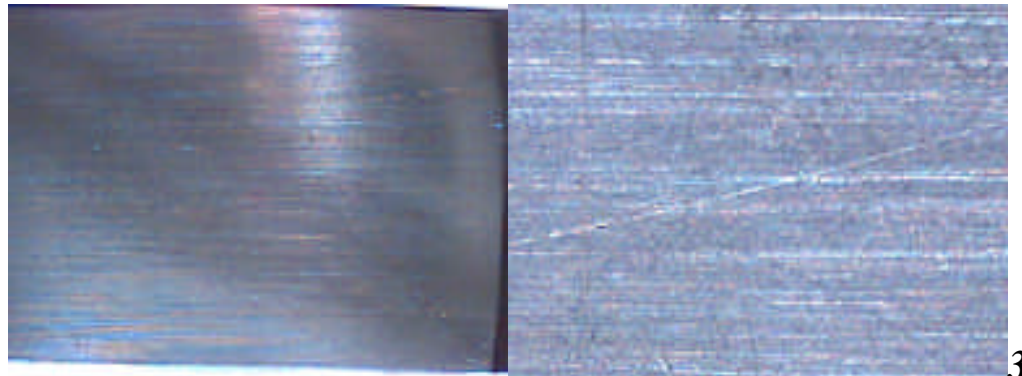

304-A
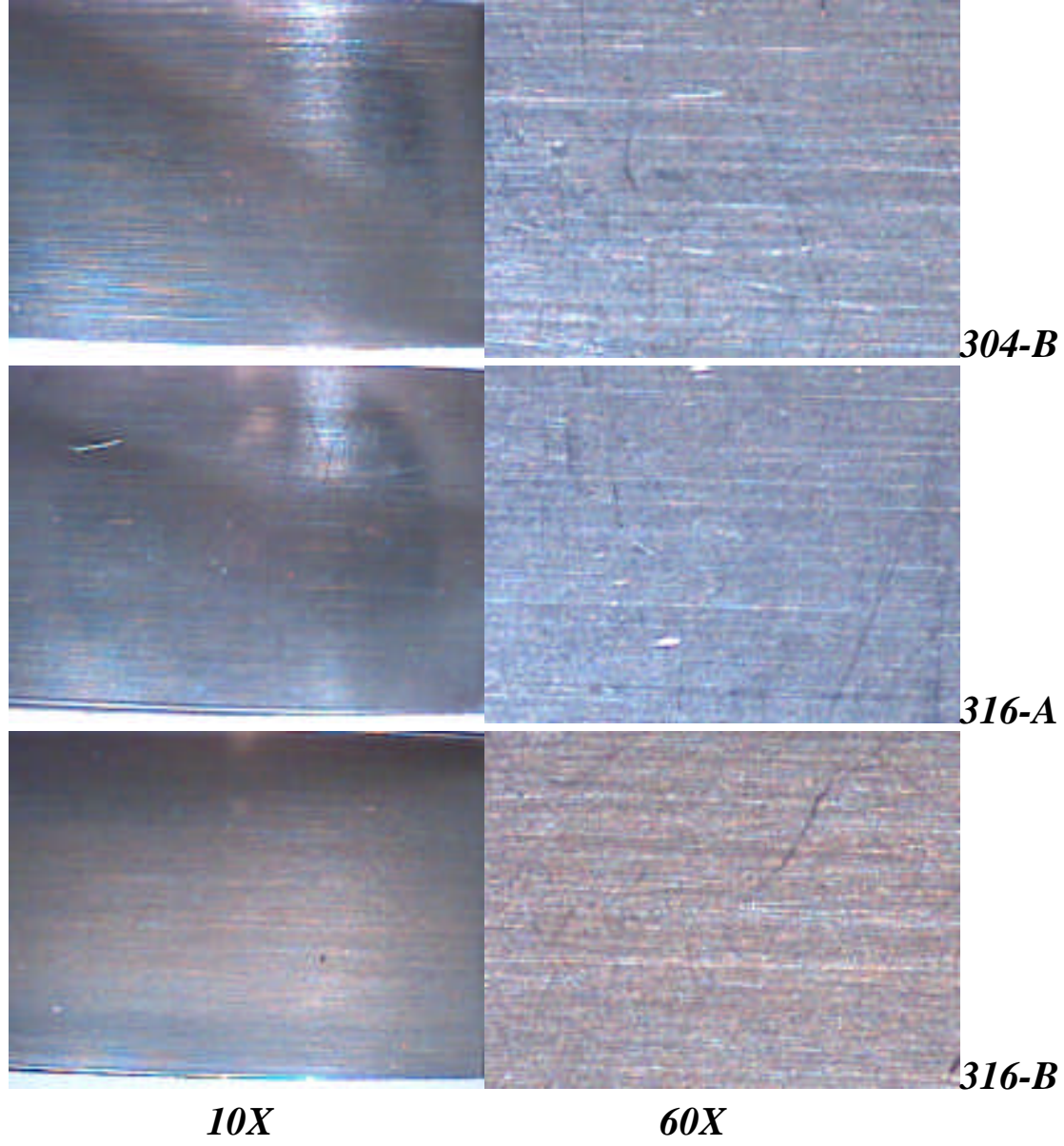
WSRC-TR-2002-00062, Rev. 0

SRT-RPP-2002-00022, Rev. 0

\section{ASTM G75 Slurry Abrasivity Determination By Miller Number System}

\begin{tabular}{|c|c|c|c|c|c|c|c|c|}
\hline \multicolumn{9}{|l|}{ Test } \\
\hline Number & \multirow{2}{*}{\multicolumn{8}{|c|}{$\begin{array}{l}\text { : S-1041 } \\
\text { : SAR Number }\end{array}$}} \\
\hline Type & & & & & & & & \\
\hline Date & \multicolumn{8}{|c|}{ 2-May-2001 } \\
\hline \multicolumn{9}{|l|}{ Project } \\
\hline Description & \multicolumn{8}{|c|}{ : Westinghouse Savannah River - AB80166N } \\
\hline \multicolumn{9}{|c|}{ 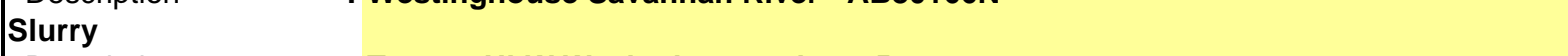 } \\
\hline Description & \multirow{2}{*}{\multicolumn{8}{|c|}{ : Test 6 - HLW Washed - $230 \mathrm{ml} \sim 265$ grams }} \\
\hline Concentration & & & & & & & & \\
\hline Temperature & \multicolumn{8}{|c|}{$: 25 \mathrm{C}+/-5 \mathrm{C}$} \\
\hline \multicolumn{9}{|l|}{ Wear Specimen } \\
\hline Description & \multirow{2}{*}{\multicolumn{8}{|c|}{ : 304L Stainless Steel }} \\
\hline Specific Gravity & & & & & & & & : 7.96 \\
\hline Hardness & \multicolumn{8}{|l|}{ : NA } \\
\hline \multicolumn{9}{|l|}{ Lap Material } \\
\hline Description & \multirow{2}{*}{\multicolumn{8}{|c|}{$\begin{array}{l}: \text { MIL-R-6855 CLASS } 2 \text { GRADE } 80 \text { NEOPRENE } \\
: 78-82\end{array}$}} \\
\hline Hardness - Durometer & : 78-82 & & & & & & & \\
\hline Wear - mm & \multicolumn{8}{|l|}{0.02} \\
\hline \multirow[t]{2}{*}{ Wear Specimen } & \multicolumn{3}{|c|}{$304 \mathrm{~L} 6 \mathrm{~A}$} & \multicolumn{3}{|c|}{$304 \mathrm{~L} 6 \mathrm{~B}$} & \multicolumn{2}{|c|}{ Cumm Loss } \\
\hline & $\mathrm{pH}$ & $\begin{array}{c}\text { Mass } \\
\mathrm{g}\end{array}$ & $\begin{array}{c}\text { Loss } \\
\mathrm{mg}\end{array}$ & $\mathrm{pH}$ & \begin{tabular}{c|} 
Mass \\
$\mathrm{g}$
\end{tabular} & $\begin{array}{c}\text { Loss } \\
\mathrm{mg}\end{array}$ & $\begin{array}{l}\text { Ave } \\
\text { mg }\end{array}$ & $\begin{array}{c}{ }^{*} \text { Best Fit } \\
\text { mg }\end{array}$ \\
\hline Initial & 8.2 & 15.5452 & 0.0 & 8.0 & 15.8453 & 0.0 & 0.0 & 0.0 \\
\hline After 2 Hours & 7.9 & 15.5302 & 15.0 & 7.8 & 15.8200 & 25.3 & 20.1 & 20.4 \\
\hline After 4 Hours & 7.8 & 15.5161 & 14.1 & 7.7 & 15.7976 & 22.4 & 38.4 & 35.0 \\
\hline After 6 Hours & 8.0 & 15.5080 & 8.1 & 8.0 & 15.7865 & 11.1 & 48.0 & 48.0 \\
\hline Total & & & 37.2 & & & 58.8 & & \\
\hline
\end{tabular}

\begin{tabular}{|llcc|}
\hline Results & & & \\
${ }^{*}$ Best Fit Mass Loss & $:$ & $=$ & $11.8655{ }^{*}$ Hours ${ }^{\wedge} 0.78000$ \\
SAR Number & $:$ & 137.56 & Relative Rate of Mass/Volume loss at 2 hours \\
Departure & $:$ & $-11 \%$ & Relative Rate of Change in Mass/Volume loss at 2 hours \\
Lap Wear & $:$ & 0.02 & $\mathrm{~mm}$ \\
\hline
\end{tabular}

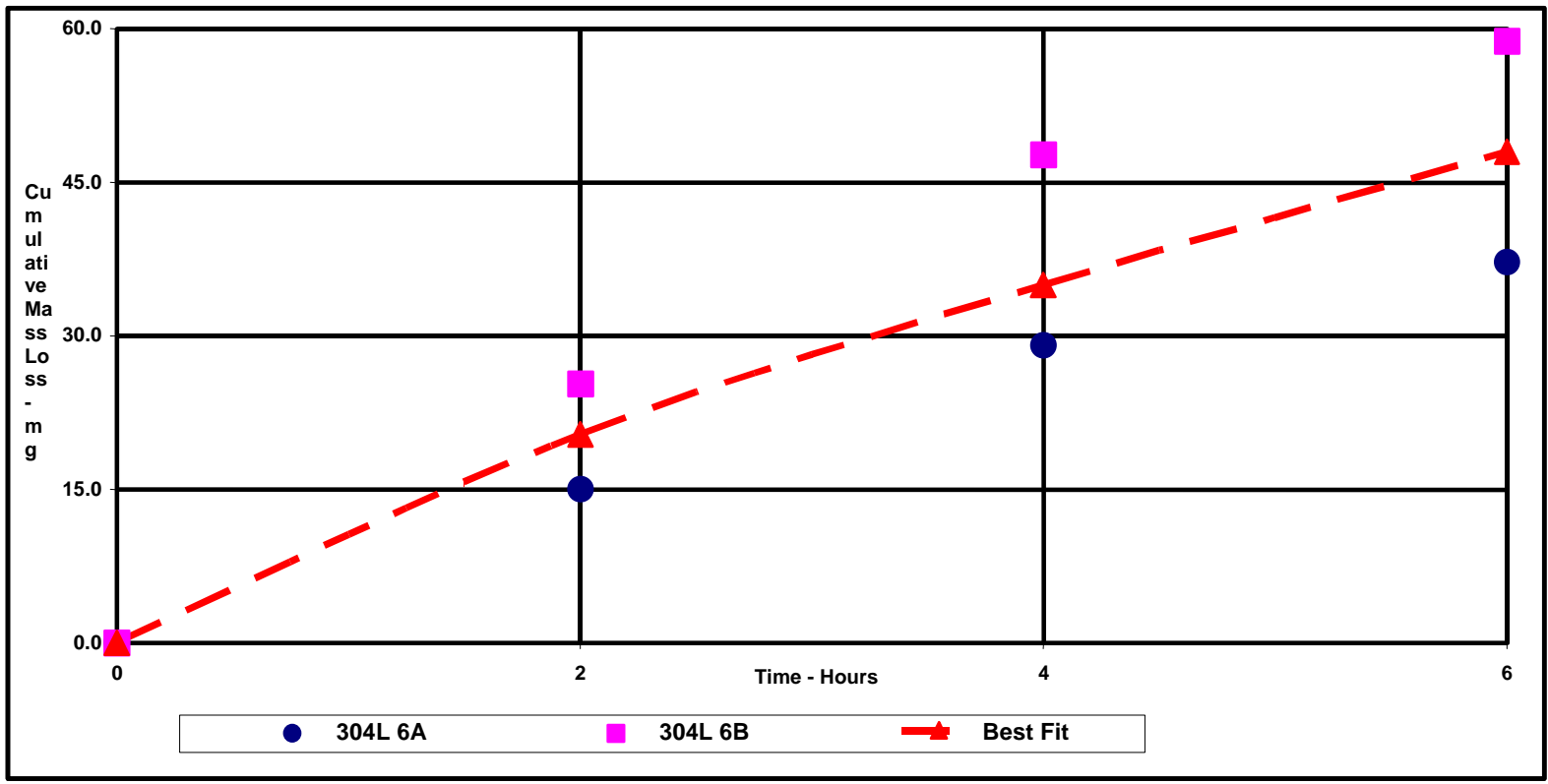


WSRC-TR-2002-00062, Rev. 0

SRT-RPP-2002-00022, Rev. 0

ASTM G75 Slurry Abrasivity Determination

By Miller Number System

\begin{tabular}{|c|c|c|c|c|c|c|c|c|}
\hline \multicolumn{9}{|l|}{ Test } \\
\hline Number & \multicolumn{8}{|l|}{ : S-1042 } \\
\hline Type & \multicolumn{8}{|c|}{ : SAR Number } \\
\hline Date & \multicolumn{8}{|c|}{ : 2-May-2001 } \\
\hline \multicolumn{9}{|l|}{ Project } \\
\hline Description & \multicolumn{8}{|c|}{ : Westinghouse Savannah River - AB80166N } \\
\hline \multicolumn{9}{|c|}{ 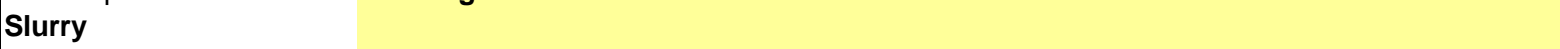 } \\
\hline Description & \multicolumn{8}{|c|}{ : Test 6 - HLW Washed $-230 \mathrm{ml} \sim 265$ grams } \\
\hline Concentration & \multicolumn{8}{|c|}{ : $20 \%$ by Mass (as received) } \\
\hline Temperature & \multicolumn{8}{|c|}{$: 25 C+/-5 C$} \\
\hline \multicolumn{9}{|l|}{ Wear Specimen } \\
\hline Description & \multicolumn{8}{|c|}{ : 316L Stainless Steel } \\
\hline Specific Gravity & \multicolumn{8}{|c|}{$: 8.00$} \\
\hline Hardness & \multicolumn{8}{|l|}{ : NA } \\
\hline \multicolumn{9}{|l|}{ Lap Material } \\
\hline Description & \multicolumn{8}{|c|}{ : MIL-R-6855 CLASS 2 GRADE 80 NEOPRENE } \\
\hline Hardness - Durometer & \multicolumn{8}{|c|}{$: 78-82$} \\
\hline Wear - mm & \multicolumn{8}{|l|}{$: 0.01$} \\
\hline \multirow[t]{2}{*}{ Wear Specimen } & \multicolumn{3}{|c|}{ 316L 6A } & \multicolumn{3}{|c|}{ 316L 6B } & \multicolumn{2}{|c|}{ Cumm Loss } \\
\hline & $\mathrm{pH}$ & $\begin{array}{c}\text { Mass } \\
\mathrm{g}\end{array}$ & $\begin{array}{c}\text { Loss } \\
\text { mg }\end{array}$ & $\mathrm{pH}$ & $\begin{array}{c}\text { Mass } \\
\mathrm{g}\end{array}$ & $\begin{array}{c}\text { Loss } \\
\mathrm{mg}\end{array}$ & $\begin{array}{l}\text { Ave } \\
\text { mg }\end{array}$ & $\begin{array}{c}{ }^{*} \text { Best Fit } \\
\text { mg }\end{array}$ \\
\hline Initial & 8.2 & 15.7325 & 0.0 & 7.8 & 15.6982 & 0.0 & 0.0 & 0.0 \\
\hline After 2 Hours & 8.1 & 15.7049 & 27.6 & 7.7 & 15.6820 & 16.2 & 21.9 & 21.7 \\
\hline After 4 Hours & 7.9 & 15.7017 & 3.2 & 7.6 & 15.6730 & 9.0 & 28.0 & 30.4 \\
\hline After 6 Hours & 7.8 & 15.6908 & 10.9 & 7.5 & 15.6656 & 7.4 & 37.2 & 37.1 \\
\hline Total & $:$ & & 41.7 & & & 32.6 & & \\
\hline
\end{tabular}

\begin{tabular}{|llcl|}
\hline Results & & & \\
${ }^{*}$ Best Fit Mass Loss & $:$ & $=$ & $15.4260{ }^{*}$ Hours^ 0.49053 \\
SAR Number & $:$ & 91.56 & Relative Rate of Mass/Volume loss at 2 hours \\
Departure & $:$ & $-25 \%$ & Relative Rate of Change in Mass/Volume loss at 2 hours \\
Lap Wear & $:$ & 0.01 & $\mathrm{~mm}$ \\
\hline
\end{tabular}

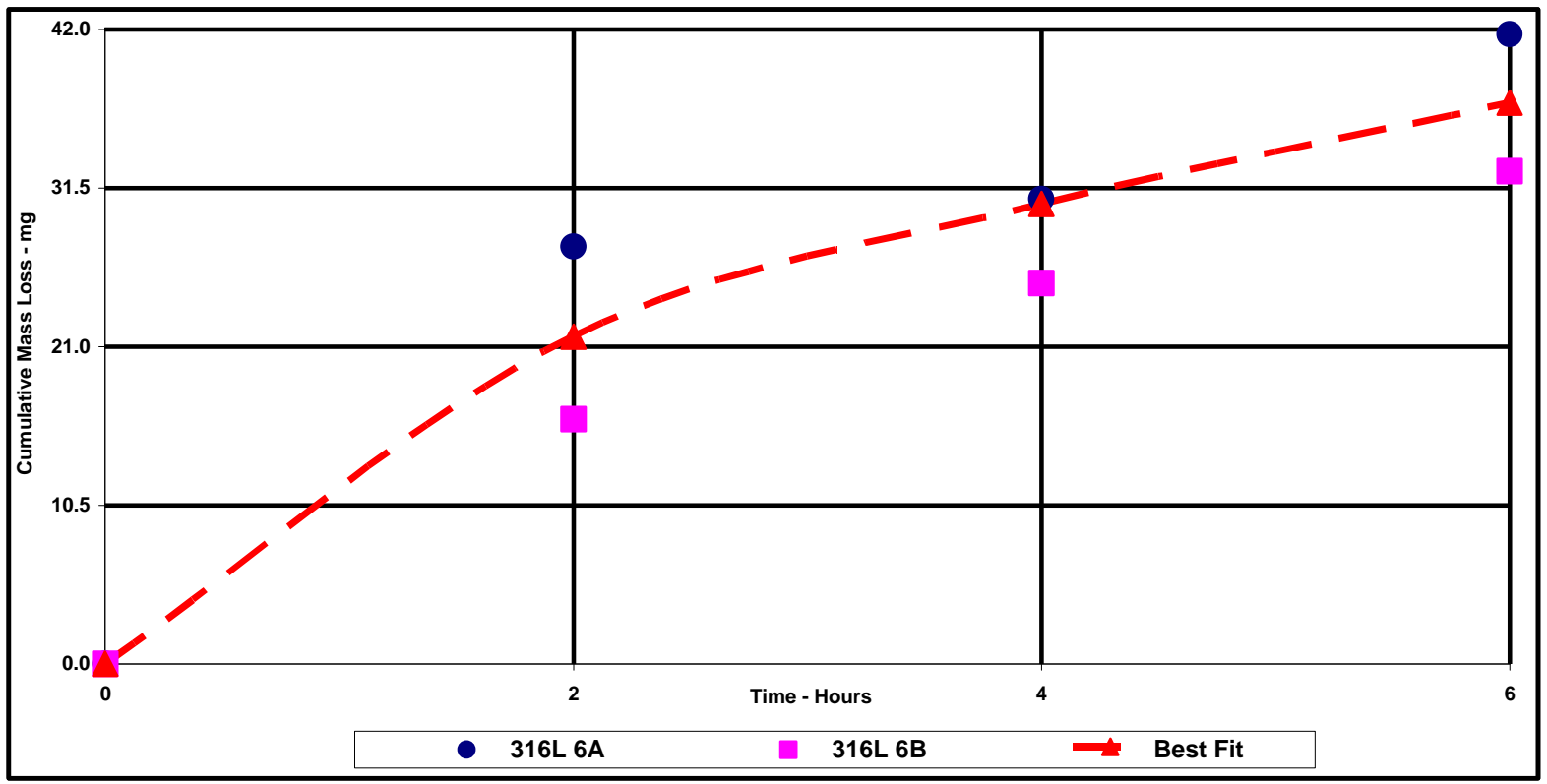


RPP-WTP Slurry Wear Evaluation: Slurry Abrasivity

WSRC-TR-2002-00062, Rev. 0

SRT-RPP-2002-00022, Rev. 0

7 - HLW Washed/Leached Slurry Test Results S-1043(304L SS) and S-1044(316L SS)
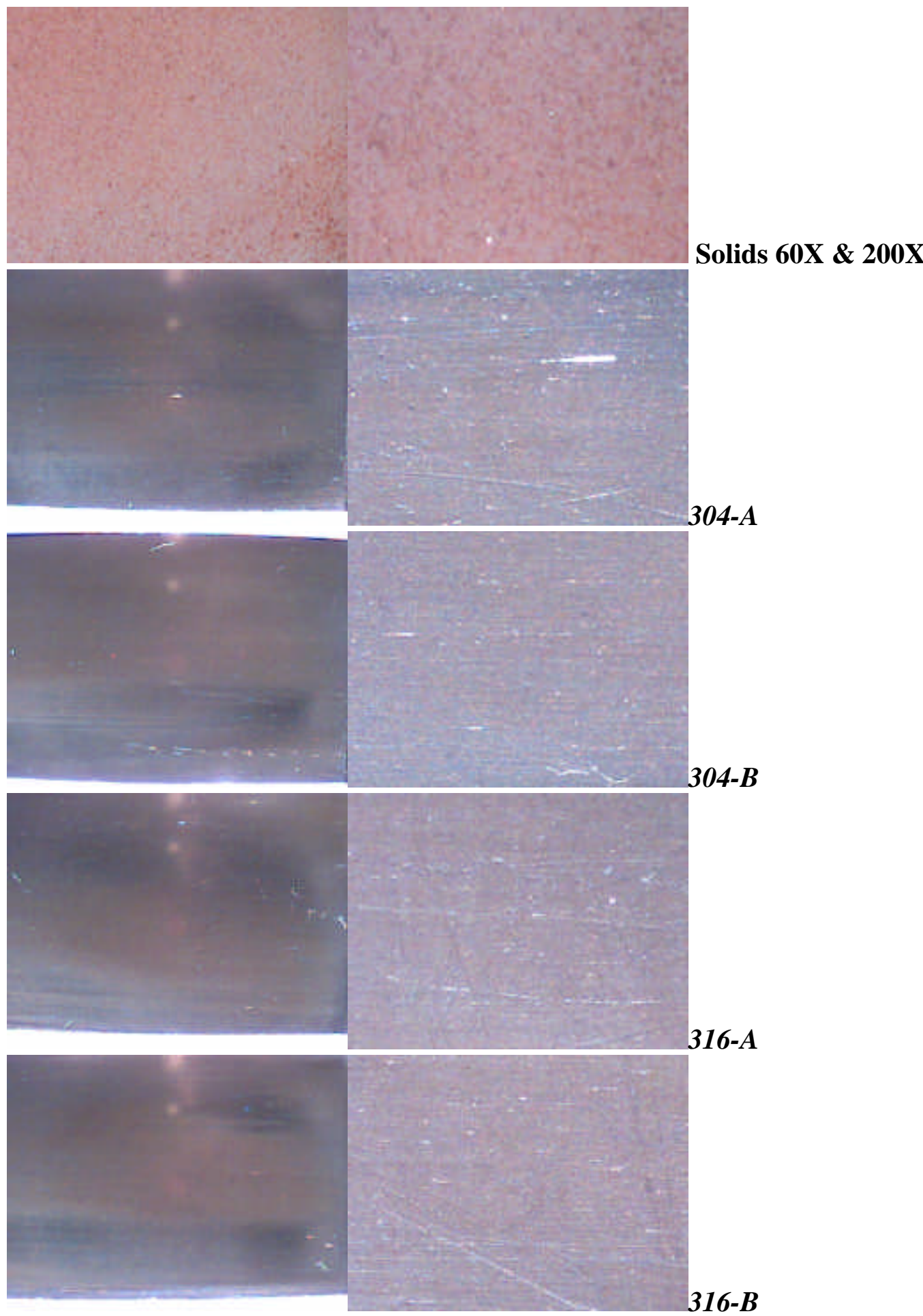

$10 X$

$60 X$ 
WSRC-TR-2002-00062, Rev. 0

SRT-RPP-2002-00022, Rev. 0

\section{ASTM G75 Slurry Abrasivity Determination \\ By Miller Number System}

\begin{tabular}{|c|c|c|c|c|c|c|c|c|}
\hline \multicolumn{9}{|l|}{ Test } \\
\hline Number & \multicolumn{8}{|l|}{ : S-1043 } \\
\hline Type & \multicolumn{8}{|c|}{ : SAR Number } \\
\hline Date & \multicolumn{8}{|c|}{ : 24-May-2001 } \\
\hline \multicolumn{9}{|l|}{ Project } \\
\hline Description & \multicolumn{8}{|c|}{ : Westinghouse Savannah River - AB80166N } \\
\hline \multicolumn{9}{|c|}{ 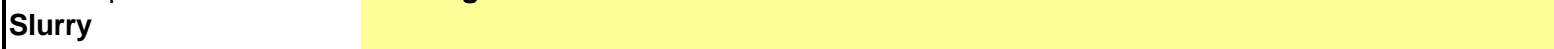 } \\
\hline Description & \multicolumn{8}{|c|}{ : Test 7 - HLW Washed/Leached - 266 \& 275 grams as received } \\
\hline Concentration & \multicolumn{8}{|c|}{ : $20 \%$ by Mass (as received) } \\
\hline Temperature & \multicolumn{8}{|c|}{$: 85 C+/-5 C$} \\
\hline \multicolumn{9}{|l|}{ Wear Specimen } \\
\hline Description & \multicolumn{8}{|c|}{ : 304L Stainless Steel } \\
\hline Specific Gravity & \multicolumn{8}{|c|}{$: 7.96$} \\
\hline Hardness & \multicolumn{8}{|l|}{ : NA } \\
\hline \multicolumn{9}{|l|}{ Lap Material } \\
\hline Description & \multicolumn{8}{|c|}{ : MIL-R-6855 CLASS 2 GRADE 80 NEOPRENE } \\
\hline Hardness - Durometer & \multirow{2}{*}{\multicolumn{8}{|c|}{$: 78-82$}} \\
\hline Wear - mm & & & & & & & & $: 0.01$ \\
\hline \multirow[t]{2}{*}{ Wear Specimen } & \multicolumn{3}{|c|}{ 304L 7A } & \multicolumn{3}{|c|}{ 304L 7B } & \multicolumn{2}{|c|}{ Cumm Loss } \\
\hline & $\mathrm{pH}$ & $\begin{array}{c}\text { Mass } \\
\mathrm{g}\end{array}$ & $\begin{array}{c}\text { Loss } \\
\mathrm{mg}\end{array}$ & $\mathrm{pH}$ & $\begin{array}{c}\text { Mass } \\
\mathrm{g}\end{array}$ & $\begin{array}{c}\text { Loss } \\
\text { mg }\end{array}$ & $\begin{array}{c}\text { Ave } \\
\text { mg }\end{array}$ & $\begin{array}{c}{ }^{*} \text { Best Fit } \\
\text { mg }\end{array}$ \\
\hline Initial & 11.3 & 15.8132 & 0.0 & 11.3 & 15.8542 & 0.0 & 0.0 & 0.0 \\
\hline After 2 Hours & 11.3 & 15.8119 & 1.3 & 11.3 & 15.8531 & 1.1 & 1.2 & 1.2 \\
\hline After 4 Hours & 11.2 & 15.8118 & 0.1 & 11.2 & 15.8525 & 0.6 & 1.6 & 2.2 \\
\hline After 6 Hours & 11.0 & 15.8097 & 2.1 & 11.0 & 15.8513 & 1.2 & 3.2 & 3.2 \\
\hline Total & $:$ & & 3.5 & & & 2.9 & & \\
\hline
\end{tabular}

\begin{tabular}{|c|c|c|c|}
\hline \multicolumn{4}{|l|}{ Results } \\
\hline${ }^{*}$ Best Fit Mass Loss & : & $=$ & $0.6446{ }^{*}$ Hours $^{\wedge} 0.89424$ \\
\hline SAR Number & : & 9.27 & Relative Rate of Mass/Volume loss at 2 hours \\
\hline Departure & : & $-5 \%$ & Relative Rate of Change in Mass/Volume loss at 2 hours \\
\hline Lap Wear & : & 0.01 & $\mathbf{m m}$ \\
\hline
\end{tabular}

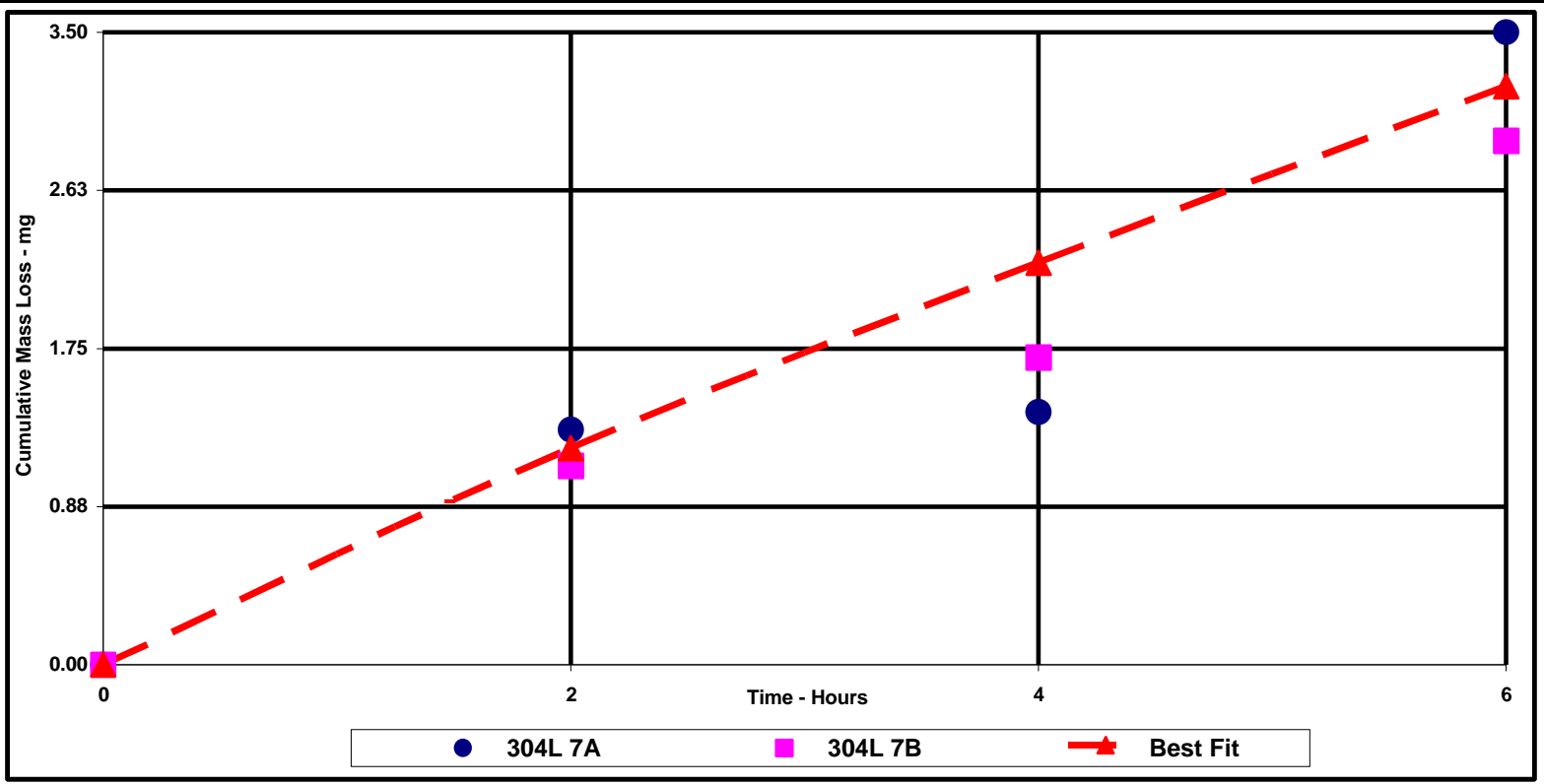


WSRC-TR-2002-00062, Rev. 0

SRT-RPP-2002-00022, Rev. 0

\section{ASTM G75 Slurry Abrasivity Determination By Miller Number System}

\begin{tabular}{|c|c|c|c|c|c|c|c|c|}
\hline \multicolumn{9}{|l|}{ Test } \\
\hline Number & \multicolumn{8}{|l|}{ : S-1044 } \\
\hline Type & \multicolumn{8}{|c|}{ : SAR Number } \\
\hline Date & \multicolumn{8}{|c|}{ : 25-May-2001 } \\
\hline \multicolumn{9}{|l|}{ Project } \\
\hline Description & \multicolumn{8}{|c|}{ : Westinghouse Savannah River - AB80166N } \\
\hline \multicolumn{9}{|l|}{ Slurry } \\
\hline Description & \multicolumn{8}{|c|}{ : Test 7 - HLW Washed/Leached - $267 \& 272$ grams as received } \\
\hline Concentration & \multicolumn{8}{|c|}{ : $20 \%$ by Mass (as received) } \\
\hline Temperature & \multicolumn{8}{|c|}{$: 85 C+/-5 C$} \\
\hline \multicolumn{9}{|l|}{ Wear Specimen } \\
\hline Description & \multicolumn{8}{|c|}{ : 316L Stainless Steel } \\
\hline Specific Gravity & \multicolumn{8}{|c|}{$: 8.00$} \\
\hline Hardness & \multicolumn{8}{|l|}{ : NA } \\
\hline \multicolumn{9}{|l|}{ Lap Material } \\
\hline Description & \multicolumn{8}{|c|}{ : MIL-R-6855 CLASS 2 GRADE 80 NEOPRENE } \\
\hline Hardness - Durometer & \multicolumn{8}{|c|}{ : 78-82 } \\
\hline Wear - mm & \multicolumn{8}{|l|}{$: 0.01$} \\
\hline \multirow[t]{2}{*}{ Wear Specimen } & \multicolumn{3}{|c|}{ 316L 7A } & \multicolumn{3}{|c|}{ 316L 7B } & \multicolumn{2}{|c|}{ Cumm Loss } \\
\hline & $\mathrm{pH}$ & $\begin{array}{c}\text { Mass } \\
\mathrm{g}\end{array}$ & $\begin{array}{c}\text { Loss } \\
\text { mg }\end{array}$ & $\mathrm{pH}$ & $\begin{array}{c}\text { Mass } \\
\mathrm{g}\end{array}$ & $\begin{array}{c}\text { Loss } \\
\mathrm{mg}\end{array}$ & $\begin{array}{l}\text { Ave } \\
\text { mg }\end{array}$ & $\begin{array}{c}{ }^{*} \text { Best Fit } \\
\text { mg }\end{array}$ \\
\hline Initial & 11.3 & 15.8964 & 0.0 & 11.3 & 15.8663 & 0.0 & 0.0 & 0.0 \\
\hline After 2 Hours & 11.3 & 15.8937 & 2.7 & 11.3 & 15.8644 & 1.9 & 2.3 & 2.1 \\
\hline After 4 Hours & 11.2 & 15.8927 & 1.0 & 11.2 & 15.8632 & 1.2 & 3.4 & 3.5 \\
\hline After 6 Hours & 11.0 & 15.8913 & 1.4 & 11.0 & 15.8622 & 1.0 & 4.6 & 4.6 \\
\hline Total & $:$ & & 5.1 & & & 4.1 & & \\
\hline
\end{tabular}

\begin{tabular}{|llcl|}
\hline Results & & & \\
${ }^{\star}$ Best Fit Mass Loss & $:$ & $=$ & $1.3280{ }^{*}$ Hours^ 0.69337 \\
SAR Number & $:$ & 12.82 & Relative Rate of Mass/Volume loss at 2 hours \\
Departure & $:$ & $-15 \%$ & Relative Rate of Change in Mass/Volume loss at 2 hours \\
Lap Wear & $:$ & 0.01 & $\mathrm{~mm}$ \\
\hline
\end{tabular}

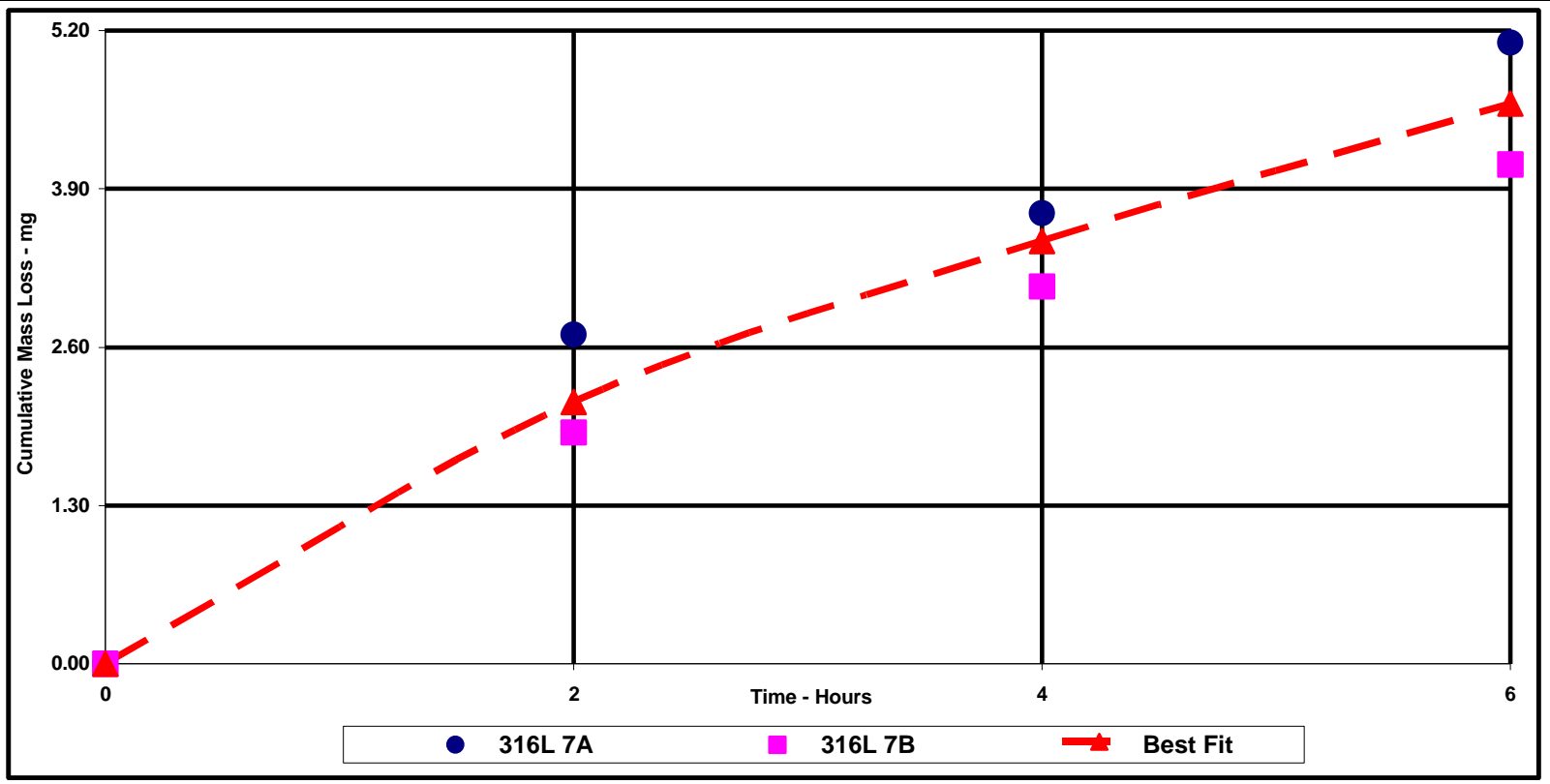


RPP-WTP Slurry Wear Evaluation: Slurry Abrasivity

WSRC-TR-2002-00062, Rev. 0

SRT-RPP-2002-00022, Rev. 0

\section{Distribution:}

W. L. Tamosaitis, 773-A

H. F. Sturm, 773-A

S. T. Wach, 773-42A

D. B. Burns, 786-5A

T. B. Calloway, 999-W

E. K. Hansen, 773-41A

C. J. Coleman, 773-A

C. A. Nash, 773-42A

S. Y. Lee, 773-42A

H. N. Guerrero, 786-5A

M. R. Duignan, 786-5A

R. A. Peterson, [Peterson, Reid] Waste Treatment Plant, 3000 George Washington Way, Richland, WA 99352

P. S. Townson, [Peterson, Reid] Waste Treatment Plant, 3000 George Washington Way, Richland, WA 99352

RPP File, c/o S. G. McKinney, 773-A, Room A-206 